“BRASIL, VISÃO DO QUE FOMOS, DO QUE SOMOS E DO QUE DEVEMOS SER": A CAUSA LUSO-BRASILEIRA EM JOÃO DE BARROS, 1912-1922

Luciana Lilian de Miranda

Tese de Doutoramento em História 
Tese apresentada para cumprimento dos requisitos necessários à obtenção do grau de Doutor em História, realizada sob a orientação científica do Prof. Doutor Fernando Rosas e coorientação do Prof. Doutor António Reis.

Apoio financeiro da Fundação para a Ciência e a Tecnologia (FCT). 
Aos meus queridos irmãos, Jussara e Laerte Júnior, que são uma grande fonte de inspiração e de amor. 


\section{AGRADECIMENTOS}

Primeiramente, gostávamos de deixar um sincero agradecimento a todas aquelas pessoas que contribuíram direta ou indiretamente para a elaboração desse trabalho.

Nessa caminhada longa e árdua, foi muito importante o acompanhamento competente e atencioso dos orientadores. Fica, portanto, registado os nossos agradecimentos ao prof. Doutor António Reis, pela leitura cuidadosa, entusiasmo, palavras de apoio e generosidade que nos foram dispensadas. Ao prof. Doutor Fernando Rosas, pela disponibilidade em nos aceitar como orientanda. Ao professor Doutor José Medeiros Ferreira, pela acolhida no percurso inicial do doutoramento. Sendo assim, são de minha inteira responsabilidade quaisquer possíveis falhas presentes nesta dissertação.

À Fundação para a Ciência e a Tecnologia (FCT), devemos as condições materiais para a realização dessa tese, sem as quais não teria sido possível.

Somos, também, grata aos funcionários da Biblioteca Museu República e Resistência (Cidade Universitária), onde desenvolvemos grande parte dessa dissertação, pela atenção e disponibilidade prestadas.

Um muito obrigada aos meus familiares, em especial ao meu pai (Laerte) e meus irmãos (Jussara e Laerte Júnior), que conseguiram contornar a distância física com palavras afetuosas e gestos de motivação.

Ao grande amigo Rodrigo, companheiro de muitos anos. Nos momentos em que tivemos dúvidas, fez-se presente. Sempre acreditou no nosso potencial de superar os desafios, contribuindo em vários níveis para a concretização dessa tese.

Às amigas queridas, Ana e Sarita, que gentilmente e generosamente auxiliaramnos a revisar o texto. À Ana Lee, pela impecável ajuda com o tradução do resumo.

Aos amigos, Larissa, Daniel, Patrícia, José, Javier, Joana, Paula e João, pelos convívios calorosos, os quais nos ajudaram a vencer os momentos de dificuldades. Relembrando os versos de Vinícius de Moraes: "a vida é a arte dos encontros...". Fica, 
ainda, registada uma nota saudosa aos amigos Luciano França e Paula Miranda (in memoriam) que, para o nosso profundo pesar, partiram cedo.

À Patrícia Maia, pela boa disposição com que partilhou a sua casa e também pela revisão do texto.

A minha psicoterapeuta (Cláudia), pelo profissionalismo e ajuda competente, a qual nos foi fundamental para criar as condições subjetivas imprescindíveis ao cumprimento das nossas metas.

Ao Miguel, pela ternura e dias felizes.

Por último, um agradecimento (in memoriam) a minha saudosa mãe (Maria Lucrécia), que com sua determinação admirável e uma vida de dedicação e de trabalho nos inspirou a encontrar as forças para ultrapassar "as pedras pelo meio do caminho". Dentre os seus ensinamentos, "achava estudo a coisa mais fina do mundo [...] não me falou em amor. Essa palavra de luxo" (Adélia Prado, Ensinamento).

Um muito obrigada a todos! 


\title{
"BRASIL, VISÃO DO QUE FOMOS, DO QUE SOMOS E DO QUE DEVEMOS SER": A CAUSA LUSO-BRASILEIRA EM JOÃO DE BARROS, 1912-1922
}

\author{
LUCIANA LILIAN DE MIRANDA
}

\begin{abstract}
RESUMO
Esta dissertação de doutoramento visou recuperar o percurso do reconhecido escritorcidadão, poeta, pedagogo, publicista e republicano português João de Barros (18811960), enquanto protagonista da campanha pela aproximação cultural luso-brasileira, nos anos de 1912 a 1922. Para situarmos melhor tal campanha, é importante destacar que houve um marcante debate de ideias sobre as relações luso-brasileiras, estimulado por grupos de intelectuais em ambas as margens do Atlântico, sobretudo, nas duas primeiras décadas do século XX.

João de Barros deixou relevante contribuição sobre as coisas e as gentes do Brasil, numa militância pela melhor compreensão entre as culturas portuguesa e brasileira. Tal empenho pode ser conferido nas onze obras dedicadas ao tema, ao lado dos inúmeros artigos publicados em periódicos e coletâneas. Devemos ressaltar, ainda, a fundação da revista Atlântida (1915-1920), numa parceria com o escritor brasileiro Paulo Barreto (1881-1921), o "João do Rio", dentre outras iniciativas que alimentaram a utopia do luso-brasileirismo.

Buscamos, portanto, analisar as ideias defendidas por Barros no conjunto de obras batizadas de Campanha Atlântica, durante a I República Portuguesa. Foram estes os anos de maior participação do nosso personagem na vida político-social do país. São deste período: A Energia Brasileira (1913), Caminho da Atlântida: uma campanha lusobrasileira (1918), A aproximação luso-brasileira e a paz (1919), Sentido do Atlântico (1921), Heróis Portugueses no Brasil (1922), Portugal, Terra do Atlântico (1923) e Olavo Bilac e Euclides da Cunha (1923).

O nosso fio condutor, no primeiro capítulo, foi o argumentário apresentado nas obras; A Energia Brasileira (1913) e O Sentido do Atlântico (1921), ambas publicadas após as duas primeiras estadias do poeta no Brasil. Buscamos, ainda, situar o pensamento do autor no contexto dos debates das correntes nacionalistas e nativistas vigentes na época, acerca do contributo da herança cultural portuguesa no Brasil e a importância do país na História lusa.

No segundo capítulo, concentramo-nos nas temáticas apresentadas na revista Atlântida (1915-1920), criada com o intuito de promover a aproximação literáriacultural entre Portugal e Brasil. Dentre os temas debatidos no mensário, destacou-se a polémica proposta de uma confederação luso-brasileira. Visamos, ainda, cotejar as leituras das revistas A Águia (1910-1932) e Nação Portuguesa (1914-1938) acerca do tema luso-brasileiro, tendo em vista que as mesmas foram coetâneas da Atlântida e representavam importantes correntes de pensamento no contexto português da época.
\end{abstract}


Dedicamo-nos, no último capítulo, a problematizar as temáticas discutidas por João de Barros nas obras Heróis Portugueses no Brasil (1922), Portugal, terra do Atlântico (1923) e Olavo Bilac e Euclides da Cunha (1923). As mesmas foram produzidas no entorno das comemorações do I Centenário da Independência Brasileira, em 1922, altura em que se deu a terceira viagem do autor ao Brasil como membro da comitiva presidencial de António José de Almeida.

PALAVRAS-CHAVE: João de Barros, relações luso-brasileiras, intelectuais e nacionalismos.

\author{
"BRAZIL, VISION OF WHAT WE WERE, WHAT WE ARE AND WHAT WE SHOULD \\ BE": LUSO-BRAZILIAN IDEAL IN JOÃO DE BARROS, 1912-1922
}

\author{
LUCIANA LILIAN DE MIRANDA
}

\begin{abstract}
This doctoral dissertation aims to retrieve the path of the writer-citizen, poet, educator, publicist and Portuguese Republican João de Barros (1881-1960) during his involvement in the Luso-Brazilian cultural campaign in the years 1912-1922. To better situate the campaign, it is important to note that there was a striking debate over Luso-Brazilian relations, spurred by intellectuals on both sides of the Atlantic, especially during the first two decades of the twentieth century.

João de Barros made a significant contribution to the things and the people of Brazil, advocating for a better understanding between Portuguese and Brazilian cultures. Such efforts can be observed in the eleven works devoted to the subject, alongside numerous articles published in journals and collections. We also stress the founding of Atlântida (1915-1920) magazine, in partnership with the Brazilian writer Paulo Barreto (1881-1921), the "João do Rio," among other initiatives that fueled the utopia of LusoBrazilianness.

We seek to analyze the ideas defended by Barros' works in conjunction to those baptized by the Campanha Atlântica during the First Portuguese Republic. These were the years of Barros' greater participation in the political and social life of the country. The works from this period are: A Energia Brasileira (1913), Caminho da Atlântida: uma campanha luso-brasileira (1918), A aproximação luso-brasileira e a paz (1919), Sentido do Atlântico (1921), Heróis Portugueses no Brasil (1922), Portugal, Terra do Atlântico (1923) and Olavo Bilac e Euclides da Cunha (1923).

The common thread that runs through the first chapter presents the argumentative rhetoric of the works: A Energia Brasileira (1913) and O Sentido do Atlântico (1921) both published after the poet's first two visits to Brazil. We also seek to situate the author's thought in the context of discussions of nationalist and nativist currents
\end{abstract}


prevailing at the timer about the contribution of Portuguese cultural heritage in Brazil and the importance of the country for Lusitanian history.

In the second chapter, we focus on themes presented in Atlântida (1915-1920) magazine, created in order to promote literary-cultural rapprochement between Portugal and Brazil. Among the issues discussed in the monthly publication is the controversial proposal of a Luso-Brazilian confederation. We aim to further collate the readings of the journals A Águia (1910-1932) and Nação Portuguesa (1914-1938) about Luso-Brazilian themes, considering that they were coeval of Atlântida and represented important currents of thought in the Portuguese context.

The last chapter problematizes the themes discussed by Barros in Heróis Portugueses no Brasil (1922), Portugal, terra do Atlântico (1923) and Olavo Bilac and Euclides da Cunha (1923). These pieces were produced during celebrations of the first centenary of Brazilian Independence in 1922 when Barros' made his third trip to Brazil as a member of António José de Almeida's presidential committee.

KEYWORDS: João de Barros, Luso-Brazilian relations, intellectuals and nationalism. 


\section{ÍNDICE}

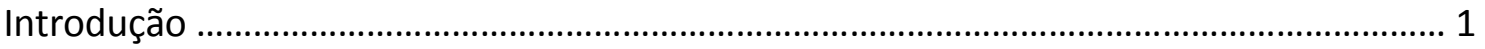

Capítulo I: João de Barros, o poeta da campanha Atlântica nos anos da I República Portuguesa

I. 1. Impressões de um enamorado: a Energia brasileira 12

I. 2. A aproximação luso-brasileira: nacionalismos e nativismos

Capítulo II: Revista Atlântida e outras vozes: pela aproximação entre Portugal e Brasil .68

II. 1. Nasce a Atlântida 70

II. 2. Uma Confederação Luso-brasileira: entre o eloquente e o polémico 85

II. 3. Leituras da relação Brasil-Portugal: A Águia e a Nação Portuguesa 103

Capítulo III: João de Barros e os diálogos com o Brasil que comemorava cem anos de Independência

III.1. Heróis Portugueses no Brasil e as comemorações do Centenário da Independência Brasileira (1922) .......................................................................... 126

III.2. Portugal, terra do Atlântico: em visita ao Brasil .......................................... 146

III.3. Olavo Bilac e Euclides da Cunha: recortes da literatura brasileira ............. 162

Conclusão 
Como foi que temperaste,

Portugal, meu avozinho,

Esse gosto misturado

De saudade e de carinho?

Esse gosto misturado

De pele branca e trigueira,

- Gosto de África e de Europa,

Que é o da gente brasileira?

Gosto de samba e de fado,

Portugal meu avozinho.

Ai Portugal que me ensinastes

Ao Brasil o teu carinho!

Tu de um lado, e do outro lado

Nós... No meio o mar profundo...

Mas, por mais fundo que seja,

Somos os dois um só mundo.

[...]

(Manuel Bandeira, "Portugal, meu avozinho”, In: Mafuá do Malundo, 1954).

"[...] Decerto, olhando a mulher brazileira, tão carinhosa, tão lenta nos seus gestos, de tão requebrado e balançado andar, de tão suave e calma elegancia, nós temos a ideia de que a familia a que ella presidir, com a honestidade terna do seu sorriso, e a sua auctoridade encantadoramente amoravel de Esposa e de Mãe, ha-de ser um ninho de tepida preguiça; decerto, o qualificativo de 'estatua de mel', que Manoel de Souza Pinto, com enternecida admiração the deu, parece-nos merecido só pelo exterior. Mas como a observação da vida de familia brazileira desmente isso! Ei-las, as requebradas, quasi dengosas elegancias de ha pouco, trabalhando, tratando dos seus filhos, fazendo do seu lar um ninho de repouso e de conforto para aquelles que tanto amam. Ei-las tecendo, com suas mãos de encanto - o encanto das horas e dos dias!"[...]. In: BARROS, João de. A Energia Brasileira, 1913: 62-63. 


\section{INTRODUÇÃO}

Nos últimos anos as relações entre Portugal e Brasil encontraram-se em evidência, a ocupar grande espaço nos órgãos da imprensa dos dois países. Assistiu-se ao desfile de autoridades brasileiras e portuguesas a celebrarem acordos e a participarem de eventos, lá e cá. Ao longo dos sete anos em que vivemos em Lisboa, pudemos acompanhar mais de perto as várias nuances que permearam as leituras dos portugueses sobre os brasileiros e a situação do Brasil no contexto mundial, e viceversa ${ }^{1}$.

Ao ultrapassarmos o discurso fácil e tão recorrente das "pátrias-irmãs", conseguimos perceber a necessidade de maior conhecimento de ambos os lados. No entanto, temos que reconhecer que esta relação será sempre mediada pela tensão alimentada pelos estereótipos, os quais se formaram ao longo da história partilhada entre Portugal e Brasil.

Uma iniciativa louvável, no sentido de estabelecer um diálogo entre as duas culturas, foi promovida pelo programa de comemorações do Ano do Brasil em Portugal e de Portugal no Brasil. Trataram-se de atividades diversificadas nas áreas da música, literatura, artes, teatro, gastronomia, ciência, tecnologia/inovação, economia/desenvolvimento empresarial e desporto, etc., realizadas simultaneamente nas principais cidades dos dois países.

Foi garantida a entrada livre em grande parte da programação e o restante viabilizado a custos reduzidos. As atividades tiveram início no dia 7 de setembro de 2012, dia da Independência do Brasil. Para o encerramento foi também escolhido um dia simbólico, 10 de junho de 2013, Dia Nacional de Portugal. O evento contou com o financiamento de verbas públicas e privadas ${ }^{2}$.

Este preâmbulo auxilia-nos a situar o interesse pelo tema da tese e fornece-nos pistas acerca da interação entre o historiador (ora) e a sua temática de estudo. Partilho

\footnotetext{
${ }^{1}$ Buscou-se, ao longo da dissertação, seguir as normas de grafia vigentes no Novo Acordo Ortográfico.

2 Conferir informações detalhadas nas páginas do evento: http://anodeportugalnobrasil.pt ; http://www.anobrasilportugal.com.br .
} 
da visão, fértil na literatura sobre o ofício do historiador (ora), de que são as inquietações do presente que nos atiram ao passado ${ }^{3}$. Foi esta perceção, aliada aos acasos da vida, que me conduziram ao tema da tese a ser apresentada. Se tivesse que dar voz ao desassossego, o qual me levou a propor este trabalho, diria: - descobrir-me brasileira em Portugal. Convém lembrar uma passagem de Sérgio Buarque de Holanda no clássico Raízes do Brasil (1936), na qual afirmava: “[...] nem o contato e a mistura com raças indígenas e adventícias fizeram-nos tão diferentes dos nosso avós de alémmar como às vezes gostaríamos de sê-lo" (2006:30).

A vivência entre os arredores de Lisboa e a bela capital encontra-se permeada por um movimento dialético de sensações e memórias. Nesta caminhada, experienciamos situações de estranhamento, não pertencimento, solidão, busca de integração, repulsa aos estereótipos, reencontro com as raízes, aceitação das diferenças e do outro. Aprendemos a lidar com o novo, inclusive aquele que em nós fora produzido, ao nos permitir conviver em diálogo com uma outra cultura.

Foi neste caminho percorrido em busca de maior compreensão das relações entre brasileiros e portugueses que chegamos ao universo dos intelectuais que se dedicaram à questão luso-brasileira. A proposta do nosso estudo é, portanto, recuperar a trajetória do escritor-cidadão, poeta, pedagogo e republicano português João de Barros (1881-1960), enquanto protagonista da campanha pela aproximação entre Portugal e Brasil.

No decorrer da pesquisa e leitura das fontes documentais, algumas questões pensadas inicialmente foram assumindo novos contornos. A princípio, consideramos abordar as relações luso-brasileiras sob o prisma político-cultural, recuperando parte do período de instauração e consolidação dos regimes republicanos nos dois países, entre 1900 e 1926. Embora, a República brasileira tenha sido implantada em

\footnotetext{
${ }^{3}$ Aprecio, particularmente, a seguinte passagem em Marc Bloch, quando o mesmo discorre sobre a relação passado-presente: “... A incompreensão do presente nasce fatalmente da ignorância do passado. Mas talvez não seja menos vão esgotar-se em compreender o passado se nada se sabe do presente. Já contei em outro lugar o episódio: eu estava acompanhando, em Estocolmo, Henri Pirenne. Mal chegamos, ele me diz: 'O que vamos ver primeiro? Parece que há uma prefeitura nova em folha. Comecemos por ela'. Depois, como se quisesse prevenir um espanto, acrescentou: 'Se eu fosse antiquário, só teria olhos para as coisas velhas. Mas sou um historiador. É por isso que amo a vida' ". In: Apologia da História ou o ofício do historiador. Rio de Janeiro: Jorge Zahar Editor, 2001, p. 65.
} 
Novembro de 1889 e a portuguesa em Outubro de 1910, a escolha de 1900 revelou-se importante como marco das representações produzidas em torno da tradição cultural luso-brasileira nas comemorações do IV Centenário do Descobrimento do Brasil. O recorte final, 1926, correspondia ao término da I República Portuguesa.

Todavia, no difícil percurso de amadurecimento de questões em torno da nossa temática, algumas mudanças fizeram-se necessárias. Novas sensibilidades e perceções surgiram a partir do estudo da instigante trajetória de João de Barros, como grande entusiasta da aproximação luso-brasileira. O escritor e homem público comprometido em promover mudanças na sociedade portuguesa da época, dedicou largos anos da sua vida a questão educacional e a campanha luso-brasileira. Entretanto, nos estudos sobre o poeta prevaleceu a análise dos textos que abordavam a questão educacional ${ }^{4}$ e a sua produção no campo literário ${ }^{5}$.

Ao lermos a documentação e a bibliografia percebemos a necessidade de suprir essa lacuna. Dedicamo-nos, portanto, a tarefa de desenvolver uma análise que privilegiasse a rica produção de João de Barros sobre o que denominamos de a "causa luso-brasileira". Para situarmos melhor tal campanha, é importante destacar que houve um marcante debate de ideias sobre as relações luso-brasileiras, estimulado por grupos de intelectuais em ambas as margens do Atlântico, sobretudo, nas duas primeiras décadas do século XX.

As singularidades das relações culturais luso-brasileiras, motivadas tanto pelos fatores herdados do passado colonial, como a língua, quanto da importância e desdobramentos da emigração portuguesa no Brasil ao longo dos séculos XIX e XX, influenciaram na conformação de uma dada perceção da identidade e da nação brasileira. Esse processo criou terreno para o discurso do luso-brasileirismo, defendido por intelectuais brasileiros e portugueses. De acordo com Jorge Luís Alves ${ }^{6}$ :

\footnotetext{
${ }^{4}$ Conferir, ESTEVES DE OLIVEIRA, Clementina Maria. O Positivismo e o Ideário Educativo de João de Barros. Porto: Publismai, 2001. FERNANDES, Rogério. João de Barros educador republicano. Lisboa: Livros Horizonte, 1960.

${ }^{5}$ Conferir, SEABRA PEREIRA, José Carlos. "Tempo neo-romântico (contributo para o estudo das relações entre literatura e sociedade no primeiro quartel do século XX". Análise Social, vol. XIX (77-78-79), 19833ㅇ, 4으, 5으, 845-873.

${ }^{6}$ Os estudos de mestrado e doutoramento desse autor foram importantes referências para o nosso trabalho. Constitui valioso contributo da perspectiva da análise das relações culturais luso-brasileiras
} 
"O luso-brasileirismo, luso-brasilismo ou luso-brasilidade defende uma representação da nação fundamentada em uma visão lusófila da história e da cultura brasileira associada também à memória coletiva da colônia portuguesa. Avaliar o luso-brasileirismo é dissecar as estratégias, intencionais ou não, de valorização do legado português na memória" (2009: 12-13).

O percurso de João de Barros insere-se nessa tradição do intercâmbio intelectual marcado pelas conceções do luso-brasilismo. Neste diálogo, mediado por tensões, as obras e ações de Barros na defesa da importância da cooperação entre Portugal e o Brasil, mostraram-se relevantes:

"[...] O que se deseja é um acordo espiritual entre as duas nações filhas do mesmo passado, gemeas pelo sentimento e pela linguagem. Porque, tudo o mais de que se fala - tatados de comércio, combinações económicas, pactos internacionaes - não valem de nada, não têm importância nem correspondem a realidades possíveis, enquanto, dentro da fórmula do respeito mútuo e da mútua independência, as duas pátrias não consagrarem, por comum afecto o que nelas existe de comum, quero dizer, a raça e as tradições. O futuro das boas relações entre Brasil e Portugal depende desse factor essencialíssimo [...]" (BARROS, Sentido do Atlântico, 1921: 76-77).

Há um outro dado importante nesta trama, a parceria de João de Barros com o talentoso cronista-jornalista carioca Paulo Barreto (1881-1921); o "João do Rio". Foi deveras marcante o encontro entre os dois escritores, na Lisboa de 1909, influenciando o despertar do interesse do escritor pelo Brasil. No entanto, João de Barros esteve presente no cenário brasileiro ao realizar viagens e próximo dos intelectuais do país, após a morte prematura de João do Rio, ocorrida em Junho de 1921. Portanto, se os estímulos iniciais emergiram desta aproximação, inclusive as

dos finais do século XIX e as primeiras duas décadas do XX, ao recuperar os elementos de rutura e continuidade, repulsa e atração dessas relações. Alves aprofunda a análise das redes de sociabilidade criadas pela elite da colónia portuguesa no Rio de Janeiro. O autor problematizou a influência das instituições criadas por esta colónia na construção de uma memória de valorização da herança portuguesa no Brasil, sobretudo da visão positiva em torno do imigrante português. Conferir: ALVES, Jorge Luís dos Santos. Imigração e xenofobia nas relações luso-brasileiras (1890-1930). Dissertação de mestrado, Universidade do Estado do Rio de Janeiro (UERJ), 1999; Malheiro Dias e o luso-brasileirismo Um estudo de caso das relações culturais Brasil - Portugal. Tese de doutorado, Programa de PósGraduação em História, Universidade do Estado do Rio de Janeiro (UERJ), 2009. 
primeiras ideias em torno da revista Atlântida $^{7}$ (1915-1920), a jornada de João de Barros continuou após a partida do seu grande aliado.

É interessante observar uma característica comum, dentre outras sensibilidades, ao estilo de vida de João de Barros e João do Rio, ambos eram intelectuais em trânsito. Diferentemente de outros escritores da época, não emigraram. Fizeram longas viagens a diferentes países, em sua maior parte, a trabalho. Pertenceram ao grupo de intelectuais que circulava, mas a base mantinha-se em Lisboa e no Rio de Janeiro.

Dentre outras mudanças ao delimitar a temática, deparamo-nos com a necessidade de rever o nosso recorte temporal. Sendo assim, tomamos como fio condutor os anos de militância do poeta em favor da causa luso-brasileira. Como ponto de partida adotamos o ano de 1912, quando se efetuou a primeira viagem de João de Barros ao Brasil. Esta deu origem a obra inaugural da campanha, intitulada $A$ Energia Brasileira (1913).

O ponto de chegada teve como destino o ano de 1922, significativo da perspectiva do conjunto de representações e eventos que marcaram as relações lusobrasileiras, no entorno das comemorações do I Centenário da Independência do Brasil. Foi também nesse ano que ocorreu a terceira viagem de João de Barros ao país, como integrante da comitiva do Presidente António José de Almeida.

A análise aqui proposta dedicou-se a recuperar e problematizar as ideias defendidas por João de Barros no conjunto de obras batizadas de Campanha At/ântica ou Luso-brasileira ${ }^{8}$, ao longo da I República Portuguesa. São deste período as seguintes obras: A Energia Brasileira (Porto, 1913), Caminho da Atlântida: uma campanha luso-

\footnotetext{
${ }^{7}$ A Atlântida: mensário artístico literário e social para Portugal e Brasil, foi publicada em Lisboa entre os anos de 1915 a 1920. Teve como diretores João de Barros em Lisboa e Paulo Barreto, no Rio de Janeiro. A revista nasceu da união entre os dois expoentes das letras, com o propósito de renovar e intensificar as relações luso-brasileiras. A análise desta revista, em diálogo com outros periódicos da época, constitui parte importante da nossa discussão.

${ }^{8}$ Foram ainda publicados pelo autor os seguintes títulos, cujo tema era o Brasil: Palavras ao Brasil: discursos. Rio de Janeiro: A Noite Editora, 1936. Alma do Brasil. Rio de Janeiro: A Noite Editora, 1937. Presença do Brasil: páginas escolhidas, 1912-1946. Lisboa, Edições Dois Mundos, 1946. Adeus ao Brasil. Lisboa: Livros do Brasil, 1961. Esta último tratou-se de uma obra póstuma, na qual foram reunidos artigos publicados no jornal Diário de Lisboa, nos anos de 1946 a 1960. No entanto, esses estudos não foram objeto da nossa análise, por terem sido produzidos num contexto histórico diferenciado e posterior ao nosso recorte cronológico.
} 
brasileira (Lisboa, 1918), A aproximação luso-brasileira e a paz (Lisboa, 1919), Sentido do Atlântico (Lisboa, 1921), Heróis Portugueses no Brasil (Lisboa, 1922), Portugal, Terra do Atlântico (Lisboa, 1923), Olavo Bilac e Euclides da Cunha (Porto, 1923). Foram estes os anos de maior protagonismo do nosso personagem na vida político-social portuguesa.

Nesse sentido, o primeiro capítulo da dissertação ("João de Barros, o poeta da Campanha Atlântica nos anos da I República portuguesa") centrou-se em abordar a trajetória de João de Barros em defesa da causa luso-brasileira no período de 1912 a 1920, anos em que foram realizadas a primeira e segunda viagens do escritor ao Brasil. O nosso fio condutor foi o argumentário do escritor. A problematização centrou-se nos principais temas abordados nas obras escritas pelo poeta com o propósito de estabelecer a tão almejada aproximação luso-brasileira: A Energia Brasileira (1913) e $O$ Sentido do Atlântico (1921).

Na primeira parte ("Impressões de um enamorado: a Energia brasileira"), procuramos recuperar as impressões do poeta sobre o Brasil, após a sua primeira estadia no país. As primeiras leituras acerca da educação brasileira, das reformas urbanas promovidas no Rio de Janeiro, do contato com os intelectuais, principalmente, João do Rio emergem de $A$ Energia Brasileira.

Para além de situar as principais questões levantadas por Barros, procuramos identificar as referências no pensamento do autor. A defesa da aproximação com o Brasil deve ser pensada à luz da sua visão sobre a sociedade portuguesa. A primeira estadia em terras brasileiras produziu um estado de enamoramento pelo país. A partir desta experiência, o Brasil aparece em várias obras do autor como fonte de inspiração ao se projetar um futuro para Portugal.

A matriz teórica-ideológica de João de Barros encontra-se filiada a uma corrente literária, da qual o mesmo foi um dos principais representantes: o NeoRomantismo Vitalista ou "literatura de intuitos". Segundo Seabra Pereira, esta corrente:

"Alimenta-se por raízes naturistas e jacobinas; desenvolve-se segundo uma dinâmica reactiva (contra o fim de século, contra o 
influxo deletério do decadentismo, contra a hipótese de recuperação ultramontana). É marcada pela ambivalência doutrinária de mestres como Teófilo Braga, Ricardo Severo e Basílio Teles. Deriva, por vezes, entre duas linhas de ruptura: o voluntarismo de Nietzche e as tendências socialistas e libertárias" (1983: 850).

$\mathrm{Na}$ segunda parte ("A aproximação luso-brasileira: nacionalismos e nativismos"), buscou-se confrontar a análise de João de Barros em O Sentido do Atlântico com os discursos das correntes nacionalistas em pauta no cenário brasileiro da época. Em linhas gerais, havia duas tendências nas organizações nacionalistas do período. Uma que se revia como tributária da herança portuguesa e reconhecia o papel dos portugueses na formação do Brasil e a outra representada por um grupo de intelectuais identificados com um nacionalismo radical nativista, que endossava uma interpretação lusófoba da história brasileira. Como porta-voz da fação nativista destacou-se a revista Gil Blas, publicada no Rio de Janeiro, nos anos de 1919-1923.

No segundo capítulo ("Revista Atlântida e outras vozes: pela aproximação lusobrasileira"), concentramo-nos num primeiro momento ("Nasce a Atlântida"), em analisar a fundação da revista Atlântida (1915-1920) e as suas principais temáticas. Órgão pensado a partir da referência vitalista, criado e dirigido por João de Barros e João do Rio, tinha como objetivo promover a aproximação cultural entre Portugal e Brasil. Buscava-se, por meio da colaboração de intelectuais dos dois países, eliminar o distanciamento e desconhecimento mútuos. Dentre as diretrizes do mensário, privilegiou-se um debate em torno do estabelecimento de uma política que pudesse favorecer a realização de acordos culturais, literários e comerciais luso-brasileiros.

Numa segunda parte (“Uma Confederação Luso-brasileira: ente o eloquente e o polémico"), tratamos das formulações em torno de uma Confederação entre Portugal e Brasil. A questão depertou muita polémica já que defendia uma união política entre os dois países. Questionou-se, assim, a autonomia e a liberdade de cada país tendo em vista uma proposta em que se considerava um governo superior comum aos dois países. Alguns setores mais radicais do nacionalismo brasileiro viam na ideia confederativa uma tentativa de recolonização por parte de Portugal. 
Na terceira parte ("Leituras da relação Brasil-Portugal: A Águia e a Nação Portuguesa"), privilegiou-se o debate sobre a relação luso-brasileira nas revistas $A$ Águia (1910-1932) e a Nação Portuguesa (1914-1938), fundadas, respetivamente, pelos grupos da Renascença Portuguesa e do Integralismo Lusitano. Embora não tenham sido formuladas com o mesmo propósito da Atlântida, estes periódicos representaram as principais correntes do pensamento filosófico-político e literário do contexto português do período. Os intelectuais envolvidos nesses projetos propuseram-se a pensar a nação e os seus rumos.

Incluímos, ainda, nesse debate um confrontamento com as ideias da publicação brasileira de cariz lusófobo; a Gil Blas (1919-1923), disponível no acervo da Biblioteca Nacional do Rio de Janeiro. Foram igualmente importantes, as cartas enviadas por João do Rio à Barros, disponíveis no acervo João de Barros da Biblioteca Nacional de Portugal.

$\mathrm{Na}$ terceiro capítulo ("João de Barros e os diálogos com o Brasil que comemorava cem anos de independência"), tendo como fio condutor as obras de João de Barros, dedicamo-nos a analisar as representações produzidas sobre a relação lusobrasileira nos eventos das comemorações do I Centenário da Independência do Brasil, em 1922. João de Barros fez parte da comitiva presidencial, liderada pelo então presidente António José de Almeida, que foi prestar homenagens ao Brasil nas celebrações centenárias. Foi o momento da terceira viagem de Barros ao Brasil. São desse período as obras: Heróis Portugueses no Brasil (1922), Portugal, Terra do Atlântico (1923) e Olavo Bilac e Euclides da Cunha (1923).

Na primeira parte ("Heróis Portugueses no Brasil e as comemorações do Centenário da Independência Brasileira, 1922"), buscou-se recuperar as diferentes versões históricas em disputa nas celebrações centenárias, as quais propunham uma avaliação do passado colonial e da herança cultural portuguesa no Brasil. Em Heróis portugueses no Brasil, João de Barros deixou registada a sua versão do período colonial, por meio de uma síntese histórica de exaltação da colonização portuguesa na formação da nação brasileira. 
Na segunda parte ("Portugal, terra do Atlântico: em visita ao Brasil), recuperamos as impressões de Barros e dos seus interlocutores da época em torno dos significados da travessia aérea Lisboa-Rio de Janeiro e da visita do Presidente António José de Almeida ao Brasil no quadro de instabilidade política do regime republicano português.

Na última parte ("Olavo Bilac e Euclides da Cunha: recortes da literatura brasileira"), buscamos inserir a leitura de Barros acerca dos escritores brasileiros Olavo Bilac e Euclides da Cunha num contexto mais amplo de debates, em que se destacavam as ideias do movimento literário modernista brasileiro. Opondo-se a dominação das culturas estrangeiras na sociedade brasileira, as correntes modernistas representadas pelos Verde-Amarelos e a Antropofagia buscavam os traços culturais que pudessem mais genuinamente representar o elemento nacional. Nesse sentido, propunham diferentes interpretações acerca da relação colonizador/colonizado e daí emergiam as principais características culturais da sociedade brasileira.

\section{CAPÍTULO I.}

\section{JOÃO DE BARROS, O POETA DA CAMPANHA ATLÂNTICA NOS ANOS DA I REPÚBLICA PORTUGUESA}

João de Barros, nascido a 4 de Fevereiro de 1881, na Figueira da Foz, recebeu inúmeras considerações elogiosas dos seus contemporâneos, sendo ainda reverenciado em contextos mais recentes pela sua obra e trajetória. No entanto, as palavras utilizadas pelo escritor brasileiro Ribeiro Couto ao apresentar o poeta pareceu-nos reveladoras: "em desacordo com a tristeza poética da sua época ... (João de Barros) era todo saúde, veemência, apetite de viver, apetite de agir. A altos gritos reclamava o sol nos dias de chuva..."

\footnotetext{
${ }^{9}$ COUTO, Ribeiro, “Prefácio”. In: BARROS, João de. Presença do Brasil: páginas escolhidas (1912-1946). Lisboa, Edições Dois Mundos, 1946, pp. XIV-XV. Rui Esteves Ribeiro de Almeida Couto (1898-1963) era um "ilustre brasileiro", conforme palavras de João de Barros. Foi poeta, contista, cronista, ensaísta, romancista, diplomata e jornalista.
} 
Filho de Ernesto Afonso de Barros (1836-1927) e de D. Mariana da Costa Guia (1838-1883). Seu pai, Visconde da Marinha Grande, enriqueceu com o comércio. Apesar do título que lhe fora atribuído pelo rei D. Carlos, em 1897, Afonso de Barros era republicano. Foi uma personalidade de destaque na Figueira da Foz, onde se dedicou a causas beneficentes e desempenhou alguns cargos, tais como o de ViceCônsul do Brasil. Transmitiu ao filho a sua admiração e algum conhecimento sobre a literatura brasileira. Desde cedo, garantiu os meios para uma boa educação ao futuro poeta.

No seu percurso, João de Barros destacou-se como escritor, pedagogo e homem público, com participações na cena política da I República portuguesa. Nas suas palavras: "Sou e nunca desejei ser senão escritor, e, nas horas de menos modéstia, um poeta que teve ou pretende ter alguma coisa para dizer em seu entusiasmo ou fervor lirico" (apud MAGALHÃES, 1979: 9).

Enquanto escritor, publicou obras relevantes em diferentes vertentes, tais como: poética, educacional, crítica literária, relações Portugal-Brasil, dentre outras. No campo da poesia destacam-se: Versos (1897), Algas (1898), Terra Florida (1909), Anteu (1912) e Sísifo (1924). No debate sobre a questão educacional: A Escola e o Futuro (1908), A Reforma da Instrução Pública (1911), A República e a Escola (1914), Educação Republicana e Educação e Democracia (1916). Sobre a literatura: O Povo na Literatura Portuguesa (1931), Pequena História da Poesia Portuguesa: esboço da sua evolução (1941) e Presenças Eternas (1943). Contribuiu, ainda, ao fazer adaptações de clássicos da literatura para crianças, tais como: Os Lusíadas Contados às Crianças e Lembrados ao Povo (1930), A Odisseia de Homero (1933); Viriato Trágico (1940), A Eneida de Virgílio contada às crianças e ao povo (1947) e Viagens de Gulliver (1957), dentre outros títulos.

No seu percurso na vida pública militou no Partido Republicano Português, posteriormente, integrando-se a fação Democrática. Foi nomeado a vários cargos, sobretudo no âmbito da educação. Dentre as funções desempenhadas, destacamos: Diretor-Geral da Instrução Pública do Ministério do Interior (1910-1911), Secretário Geral (interino) do Ministério da Instrução Pública (1914), Diretor Geral do Ensino 
Primário (1915), Secretário Geral do Ministério da Instrução Pública (1919), dentre outros. Foi ainda deputado pelo Círculo de Lamego (1913) na lista do Partido Republicano Português e Ministro dos Negócios Estrangeiros (1924-1925), durante o Governo Domingues dos Santos.

Recebeu várias distinções ao longo da vida, das quais citamos: oficial da Ordem Leopoldo II (1920), do governo belga; a Grã-Cruz da Ordem Militar de Cristo (1923), do Presidente da República Portuguesa; a Grã-Cruz da Ordem El Sol del Peru (1925); a GrãCruz da Ordem do Cruzeiro do Sul (1944), do Presidente da República do Brasil.

João de Barros era o que poderíamos chamar de um intelectual engajado e como tal dedicou-se a algumas causas, dentre as mesmas: a questão educacional e a campanha luso-brasileira. No que tange ao ensino, buscou combater o analfabetismo e promover uma educação nacionalista e hábil em preparar os indivíduos para o futuro e para a integração na sociedade.

Defendia um ensino antidogmático e antiautoritário, que pudesse forjar a inteligência a partir do desenvolvimento livre do espírito infantil. E assim propugnava: "Não dar ao futuro almas do passado, almas como as nossas vivendo do que já viveu, tremendo do que já não existe: _ mas energias livres, indomadas, virgens - e aptas a tornar mais bellas, mais intensas e mais complexas as ideias, as luctas, as ambições desse Futuro, que há de ser o seu presente ${ }^{10 "}$ (A Escola e o Futuro, apud FERNANDES, 1960: 17).

A respeito do papel desempenhado pelo escritor acerca da matéria, Rogério Fernandes teceu as seguintes considerações:

"João de Barros foi uma das figuras de maior projecção durante a Primeira República, na esfera das questões educacionais, sobretudo nos sectores do ensino primário e secundário. Os livros que publicou sobre a matéria e as responsabilidades públicas que assumiu nesse domínio, devido aos cargos oficiais que ocupou no respectivo Ministério, tornaram a sua obra e a sua acção num documento significativo de uma das épocas mais importantes e decisivas da História da Instrução Pública no nosso País" (idem: 12).

\footnotetext{
${ }^{10}$ Optamos por manter a grafia de época em todas as citações.
} 
A outra causa a qual se dedicou, isto é, a campanha de aproximação lusobrasileira, constitui o nosso tema de reflexão. Pouco analisada, se compararmos aos estudos relativos a produção na vertente pedagógica, mas não menos importante ou consistente.

João de Barros deixou importante contribuição sobre as coisas e as gentes do Brasil, numa militância pela melhor compreensão entre as culturas portuguesa e brasileira. Veio a falecer ao entardecer de 25 de outubro de 1960, em Lisboa, “... numa calma serenidade, depois de ter trabalhado de manhã na preparação de um artigo que se destinava ao Diário de Lisboa, onde há longos anos assiduamente colaborava, e cujo tema era uma vez mais o Brasil" (Nota Final, BARROS, Adeus ao Brasil, 1961: 288).

O nosso interesse em desvendar este emblemático personagem do mundo das letras portuguesa, justifica-se, portanto, devido ao seu protagonismo na campanha pela aproximação entre Portugal e Brasil, na primeira metade do século XX. Tal empenho pode ser conferido ao longo das onze obras dedicadas ao tema, ao lado dos inúmeros artigos publicados em periódicos e coletâneas. Devemos ressaltar ainda a fundação da revista Atlântida (1915-1920), numa parceria com o escritor brasileiro Paulo Barreto (1881-1921), o "João do $\mathrm{Rio}^{11}$, dentre outras iniciativas que alimentaram a utopia do luso-brasileirismo ou luso-brasilismo.

Trataremos a seguir, das impressões transmitidas pelo poeta na altura da sua primeira viagem ao Brasil em 1912, buscando referenciar as suas ideias com base nos contextos brasileiro e português da época.

\section{I.1. Impressões de um enamorado: a Energia brasileira}

João de Barros foi convidado a apresentar uma conferência em comemoração ao aniversário da República Brasileira nos idos de 1912, poucos meses após o retorno

\footnotetext{
${ }^{11} \mathrm{O}$ uso de pseudónimos era recorrente na imprensa e nas letras brasileira, assim como em outros países. Paulo Barreto utilizou-se de vários: Joe, Claude, Simeão, José Antônio José. Alguns destes coexistiram por determinados períodos e expressavam diferentes perfis, aproximando-se de heterónimos. No entanto, é curioso que o seu pseudónimo mais conhecido; João do Rio, lançado em 1903, tenha suplantado a identidade do escritor (RODRIGUES, 1996: 49).
} 
da sua primeira viagem ao Brasil. A propósito do convite, recorreu às seguintes palavras como justificativa: “... o enthusiasmo ardente com que há pouco regressei do Brazil, seduzido, maravilhado, encantado com o paiz admiravel" (1913: 11). A conferência teve lugar no antigo Teatro da República (atualmente, Teatro São Luiz), na Lisboa de 14 de Novembro do referido ano.

Esta primeira declaração sugere o estado de arrebatamento do nosso poeta pelo Brasil. As impressões geradas por este debute em terras brasileiras nos servirão de guia para situarmos algumas das questões, as quais permearam as leituras sobre a relação Portugal-Brasil no período.

Convicto na sua defesa do regime republicano, João de Barros argumentava que a estrutura criada e mantida pelo Império não fora capaz de suportar as mudanças e as forças progressivas manifestas na sociedade brasileira da época. Neste sentido, a implantação da República no Brasil (1889), fez-se para: “[...] _ abrir caminho à civilisação, permittir que se desenvolvessem, que triunphassem as forças latentes d'aquelle paiz prodigioso de vitalidade. Por isso, nós, portuguezes, devemos celebrar esta data com especial carinho: _ a nossa revolução republicana tambem significa desejo de viver mais e melhor [...] (1913: 10-11)".

Alguns estudos analisaram as relações estabelecidas entre o republicanismo brasileiro e o português. Segundo Luísa Maria Barbosa ${ }^{12}$, observou-se um considerável destaque à "Revolução Brasileira Republicana" de Novembro de 1889, atribuído pela propaganda republicana portuguesa, registada nos periódicos que defendiam este ideário. Os vapores e telégrafos foram importantes aliados para ultrapassar as barreiras de comunicação e possibilitar um intercâmbio de ideias entre os republicanos dos dois países.

Alguns fatores e eventos contribuíram na proximidade destes movimentos. Desde 1870, o Positivismo constituiu-se como importante base filosófica para o republicanismo nos dois países. As comemorações do Tricentenário de Camões (1880)

\footnotetext{
12 BARBOSA, Luísa Maria Gonçalves Texeira. O ideário republicano nas relações Brasil-Portugal, 18801891. Tese de Mestrado, Faculdade de Letras, Universidade de Lisboa, 2002. Conferir, ainda, GONÇALVES, Eduardo Cândido Cordeiro. Ressonâncias em Portugal da Implantação da República no Brasil (1889-1895). Porto: Reitoria da Universidade do Porto, 1995.
} 
propiciaram um espaço para a formalização do intercâmbio entre intelectuais republicanos portugueses e brasileiros. A Revista Estudos Livres ${ }^{13}$, concebida por Teófilo Braga entre 1882 e 1883, promoveu um estreitamento desta interação.

Nesta conferência, João de Barros discorreu sobre a sua primeira viagem ao Brasil (1912), deixando assentadas as suas impressões acerca daquele país, sobretudo, dos lugares por onde circulou; as cidades do Rio de Janeiro e de São Paulo. No ano seguinte, a mesma foi publicada e deu origem ao livro intitulado A Energia Brasileira.

O convite e a receção foram organizados por João do Rio, o qual tornar-se-ia um amigo próximo. A obra foi dedicada fraternalmente ao amigo escritor. Na segunda viagem $^{14}$ de visita à Europa, em 1911, João do Rio esteve em Lisboa e defendeu exaltadamente uma aproximação cultural luso-brasileira oficial. Este episódio ocorreu junto da Livraria Teixeira, um dos pontos de reuniões dos escritores da época, num encontro com os amigos Manuel de Sousa Pinto $(1880-1934)^{15}$ e João de Barros.

No retorno ao Rio de Janeiro, o escritor carioca levou adiante a ideia do aprofundamento das relações entre Brasil e Portugal. Neste sentido, incentivou a colónia portuguesa da capital a convidar intelectuais lisboetas a visitarem o Brasil. Obteve, ainda, apoio do então Ministro das Relações Exteriores, Lauro Muller, neste projeto. O primeiro convidado desta iniciativa viria a ser João de Barros ${ }^{16}$.

\footnotetext{
${ }^{13}$ A Revista de Estudos Livres (1883-1886) visava "reatar a aliança mental luso-brasileira", num contexto de "crise de transformação mental e política em que vão entrando as duas nacionalidades portuguesa e brasileira", a partir da divulgação de investigações que "conduzam para um ponto de vista social" (Apud, PAREDES, 2006: 113). Possuía diretoria "literário-científica" em Portugal e no Brasil. Do lado português, assinavam Teófilo Braga e Teixeira Bastos; do brasileiro, Silvio Romero e Karl von Koseritz. Apesar das polémicas travadas entre Braga e Romero, havia uma base comum na diretriz da revista, isto é, a visão cientista-positivista do estudo das histórias e das culturas nacionais. Conf.: PAREDES, Marçal de Menezes. "A Querela dos Originais: notas sobre a polêmica entre Silvio Romero e Teófilo Braga". Estudos Ibero-Americanos. PUCRS, Edição Especial, n. 2, p. 103-119, 2006.

${ }^{14}$ A primeira realizou-se em 1909. Esta deu origem aos relatos e crónicas publicados no livro Portugal d'Agora, editado em 1911 com dedicatória a João de Barros e ao escritor Manuel de Sousa Pinto.

${ }^{15}$ Manuel de Sousa Pinto foi escritor, historiador, docente universitário, publicista e crítico literário, de arte e dança. Nasceu no Brasil, no entanto, cresceu e educou-se em Portugal. Dirigiu juntamente com João de Barros a revista Arte e Vida (1904-1906), publicada em Coimbra. Foi um grande conhecedor da literatura brasileira e um dos professores da cadeira de Estudos Brasileiros da Universidade de Lisboa, entre 1923-1934. Publicou o livro Terra Moça, em 1910, com vários textos nos quais registou as suas leituras sobre factos, lugares e costumes brasileiros, oriundos das estadias no país.

${ }^{16}$ Conferir RODRIGUES, João Carlos. João do Rio: uma biografia. Rio de Janeiro: Toopbooks, 1996, pp. 128-229; 146.
} 
Desta primeira experiência em terras brasileiras, afirmou-se o entusiasmo do poeta pelo país. Este foi o ponto de partida da Campanha Atlântica ou Luso-brasileira. Conforme mencionado anteriormente, João de Barros dedicou-se a escrever onze livros e inúmeros artigos em periódicos, com o objetivo de sensibilizar o público acerca da importância de uma aproximação entre Portugal e Brasil. A denominação Campanha Luso-brasileira apareceu como subtítulo nas obras consecutivas; Caminho da Atlântida (1918) e Sentido do Atlântico (1921).

Cabe aqui uma breve reflexão sobre o termo luso-brasileiro. Deve-se ressaltar, que a apropriação do mesmo no sentido de uma comunidade intercultural remete ao início do século XX. Nelson Vieira considera o uso da expressão para se descrever o movimento de interação cultural promovido, sobretudo, nas primeiras décadas do século entre intelectuais dos dois países. No seu estudo acerca da imagem recíproca, difundida nas obras literárias entre Portugal e Brasil, afirma: "Em outras instâncias, o termo é usado simplesmente para fazer alusão à existência (préséculo XX) de elementos culturais relevantes para ambos os países" (1991: 15).

Para entendermos o empenho de João de Barros ao que intitularemos de "a causa luso-brasileira", considerada por alguns de seus contemporâneos um verdadeiro apostolado, é necessário recuperar como o escritor concebia o seu país. É a partir desta visão e do seu comprometimento com a pátria portuguesa que a aproximação com o Brasil assume um significado.

Nessa perspectiva, é interessante pensar no conceito de energia, proposto pelo autor na primeira obra da campanha. Ao estabelecer uma analogia entre as fadas, a sua magia e a energia humana, dizia João de Barros:

“[...] Não sei porque, sempre julguei que as fadas representavam uma humanidade superior, e esta varinha magica, e o gesto que a agitava, representavam, symbolisavam (que Anatole France, o auctor de tão lindas interpretações de contos de fadas, me perdoe esta interpretação!...) - uma superior vontade humana vencendo os obstaculos da vida, as circumstancias más que nos deprimem, as duvidas e as fraquezas que a negam" (A Energia Brazileira, 1913: 1314). 
Afirmou ainda que acreditava na ilimitada confiança do poder da humanidade e "na permanente victoria do homem sobre o mundo" (idem: 15). No entanto, tal fé teria sido abalada pelas dificuldades e apatia da vida, refletidas no lento processo de ressurgimento de Portugal, "eivado ainda de tantas das fraquezas que os seus antigos governantes Ihe communicaram [...]" (ibidem: 16).

O convite para a viagem ao Brasil, dizia o nosso poeta, o resgatou deste estado de fadiga e desânimo. E assim o desembarque no Rio de Janeiro foi identificado como a chegada ao "paiz chymerico das fadas n'um paiz em que os homens possuiam - os felizes! Essa mesma varinha de condão, essa energia creadora [...]" (idem, ibid.: 19).

Trata-se da exaltação do poder realizador do trabalho, daquilo que é produto do esforço humano. O conceito de energia e o sentido de exaltação à vida propagado por João de Barros teve como base as ideias defendidas pelo neo-romantismo vitalista e emancipalista português do início do século XX.

Esta corrente literária, da qual o poeta tornou-se um grande expoente, propunha uma literatura de "intuitos", com vistas a intervenção na realidade. Os críticos e escritores empenhados neste movimento repudiavam a literatura como mero gozo artístico e defendiam uma subversão dos modelos tradicionais de mentalidade e de comportamentos, comprometidos "no combate de ideias e nas movimentações políticas - em nome de opções 'progressistas' (republicanas e maçónicas, por vezes também socialistas ou anarquistas)". Apesar da pluralidade ideológica, este grupo convergia no republicanismo e no anti-clericalismo (PEREIRA, 2010: 339).

No contexto da viragem do século XIX para o XX, nota-se uma retração das correntes simbolista e decadentista, permeada por uma crescente valorização da tradição nacional em oposição ao cosmopolitismo. Entre o Ultimatum Inglês (1890) e o Regicídio (1908) evidenciou-se o fortalecimento das pressões pelo engajamento literário, o qual seria legitimado nas poéticas neo-românticas. Eram tempos de "poetacidadão" e de "escritor-guardião da Pátria" contrários à apatia literária finissecular manifestas na escrita simbolista e decadentista (idem: 356). 
As ideias e literatura expressas pelo vitalismo neo-romântico português tornaram-se hegemónicas na primeira década do século XX. Entretando, nas décadas consecutivas foram ofuscadas por outras duas correntes neo-românticas; a saudosista e a lusitanista. Interassa-nos, neste momento, discorrer um pouco mais acerca do vitalismo para entendermos melhor a matriz do pensamento de João de Barros, tendo em vista o peso desta influência na visão sobre o Brasil.

O núcleo fundador desta corrente teve como principais representantes os então jovens escritores e críticos republicanos; João de Barros, Mayer Garção (18721930) e Sílvio Rebello (1879-1933), os quais constituíram o eixo Coimbra-Lisboa. Registou-se ainda um desdobramento portuense em torno de Manuel Laranjeira (1877-1912). A proposta de renovação literária teve visibilidade por meio do lançamento de periódicos, tais como; Revista Nova (Lisboa, 1901-1902), Mocidade (Lisboa, 2a e 3a séries, 1902-1906), Arte \& Vida (Coimbra, 1904-1906) e também da publicação de textos em jornais republicanos, como $O$ Mundo $^{17}$ e $O$ Norte ${ }^{18}$.

Os autores do vitalismo neo-romântico tinham origem social predominantemente na pequena e média burguesia urbana. Para além dos principais expoentes citados, podemos acrescentar: Nunes Claro (1878-1949), Bernardo de Passos (1876-1930), Angelina Vidal (1847-1917), Campos Lima (1877?-1956), Tomás da Fonseca (1887-1968), José Augusto de Castro (1862-1942), Eduardo Metzner (18891922), Ângelo Jorge (1883-1922), Joaquim Manso (1878-1956), Manuel de Souza Pinto, João de Deus Ramos (1878-1953), Ramada Curto (1886-1961), dentre outros.

Segundo Seabra Pereira, o embasamento filosófico da corrente vitalista era heterogéneo. A herança do século XIX aparecia no destaque concedido ao monismo de Haeckel (1834-1919) ${ }^{19}$, expressivo na receção e influência exercida pela obra do

\footnotetext{
17 Importante órgão combativo da imprensa republicana, publicado no período de 16-09-1900 a 9-121935. O jornal foi fundado em Lisboa pelo jornalista António França Borges em 1900, que o dirigiu até a sua morte em 1915.

${ }^{18}$ Diário Republicano, Porto, 1900-1910. In: FERNANDES, Raúl de Matos. Jornais do Porto: 1896-1925. Coimbra, 1978, p. 77. Acesso em: http://books.google.pt/

${ }^{19}$ Filósofo e naturalista alemão, divulgou o evolucionismo social contrapondo-se ao obscurantismo dos religiosos nesta questão. Defendeu que cada indivíduo reproduz a evolução geral da natureza. Desenvolveu a filosofia monista, na qual estabelece o vínculo entre a matéria e espírito: “...uma concepção unitária da natureza inteira ... um espírito está em tudo e todo o mundo conhecido existe e se desenvolve por uma lei fundamental comum. Por isso insistimos particularmente na unidade
} 
biólogo francês Félix Le Dantec (1869-1917) ${ }^{20}$. Estas referências tornaram João de Barros e os seus companheiros agnósticos empedernidos. Igualmente herdeiros do jacobinismo e do naturalismo literário francês, esses escritores refletiam uma atitude mental que:

"[...] deixa de se angustiar perante o correr do tempo, para cuidar de fruir com euforia a existência; ignora o tédio e exige a aceitação originária da vida toda, enquanto dado irrecusável da condição humana, da situação do homem que se descobre apenas vivente; condena o mal introduzido nessa vida: não o mal metafísico, mas os males praticados por homens submetidos a preconceitos sociais e a forças ideológicas obscurantistas; encara como dado natural que a vida se configure como luta, mas transforma esse dado em atitude consciente e voluntária, dando-lhe a dimensão de acção transformadora do mundo, sob o signo do optimismo" (1983: 854).

Um outro paradigma importante associado à corrente literária e com destaque na escrita de João de Barros trata-se do Super Homem nietzschiano ${ }^{21}$. A vontade de fazer e de querer expressa nos poemas e exaltada nos textos educacionais, inpira-se neste "Super Homem" ou "além do homem", aquele que é capaz de ultrapassar a si próprio. A ideia da superação aparece também nas metáforas do poema $O$ Velho Navio (CAMILOTTI, 2012:3-4) ao sugerir uma leitura sobre os destinos do país. Nestes versos,

fundamental da natureza orgânica e inorgânica, cuja última começou relativamente tarde a evolucionar da primeira... repelimos a diferença habitual entre a ciência da natureza e a do espírito... as duas não fazem mais do que uma. A nossa concepção monista do universo pertence pois a esse grupo de sistemas filosóficos que se designam, sob um outro ponto de vista, com os nomes de mecanistas ou panteístas ... subsistem no entanto as idéias fundamentais comuns da unidade cósmica, da solidariedade inseparável da força e da substância, do espírito e da matéria ou, como também se pode dizer, de Deus e do mundo". In: Ernest Haeckel. O Monismo, Porto: Chardron, 1908, pp. 11-12. Acesso em: http://www.ebooksbrasil.org/adobeebook/monismo.pdf

${ }^{20}$ Biólogo e positivista dissidente a quem foi associado a utilização do termo "cientismo". Segundo esta conceção, a ciência seria capaz de resolver todos os problemas humanos, assumindo atributos da religião. Criou uma espécie de metafísica monista, conhecida também como filosofia biológica. Segundo esta filosofia, a realidade total compreendia a unidade entre a matéria, a vida e o espírito. Colaborou na Revista Arte \& Vida. Obras: L'indivualité et le erreur individualiste, (1897), L'athéisme (1906), Éléments de philosophie biologique (1911), L'égoisme seule base de tout societé (1911), Contre la métaphysique (1912), Le problème de la mort et la conscience universelle (1917), dentre outras. In: Enciclopédia Simpozio; http://www.cfh.ufsc.br/ simpozio/novo/2216y840.htm .

${ }^{21}$ Nesta perspectiva; “...Nietzsche é visto como médico duma cultura enferma e o seu pensamento saudado como fio de Ariadne, capaz de orientar o homem para a saída do labirinto do pessimismo vigente. É a essa luz que João Grave e João de Barros, entre outros, abordam o seu pensamento". In: MONTEIRO, Américo Eneas. A recepção da obra de Friedrich Nietzsche na vida intelectual portuguesa (1982-1939). Dissertação de Doutoramento em Cultura Alemã. Faculdade de Letras da Universidade do Porto, 1997, pp. 35-36. Acesso em http://repositorio-aberto.up.pt/handle/10216/10857 
o poeta incita os portugueses a superar a velha cantilena do passado glorioso e inventar um futuro:

"Quebra as amarras,

Navio triste, adormecido junto ao caes!

Não oiças mais

A voz nervosa, a voz chorosa das guitarras

$[\ldots]$

Parte depressa, foge breve, ó meu Navio,

É o futuro que te chama, ó coração!

$[\ldots]$

Vae para o Mar!

Pois só o Mar, que é traiçoeiro, é que não mente:

- Floresce em ilhas para o naufrago impaciente

E para o sonho que deseja repousar.

Simples miragem?... O que importa? Se a miragem

Nos trouxe a febre de partir e de aportar,

A primavera renascente da viagem!...

Deixa o Passado junto ao caes, ó meu Navio!

$[\ldots]$

Vae para o Mar! $!^{22}[\ldots]^{\prime \prime}$.

O desejo de ir além deveria ser mobilizado pela miragem de um futuro a ser construído. É nesta busca de uma imagem ou de sentidos "nos horizontes (em que) vão romper novas auroras" que a proximidade com o Brasil assume um significado. 0 encantamento provocado pela sua primeira estadia na "terra de luz" ${ }^{23}$ acena com um sentido de porvir. É a partir desta viagem, que o Brasil se faz presente ao longo dos anos na obra de Barros, enquanto utopia e terra prometida das conceções antropológicas. Emerge como o país da plena energia como modelo e dynamis do programa estético-político que a "literatura de intuitos" se infligiu (PEREIRA, apud CAMILOTTI, 2012: 8).

Ao seguir o relato em A Energia do Brasileira, nota-se que o poeta observava, a partir dos primeiros contactos, que havia um empenho em se chamar a atenção para o trabalho de transformação e de modernização empreendido no Rio de Janeiro. Nesse sentido, enfatizava o tom do diálogo estabelecido na sua chegada: “... o amigo que me

\footnotetext{
${ }^{22}$ BARROS, João de. Anciedade, 1913, pp. 53-55.

${ }^{23}$ Título de abertura conferido por João de Barros aos três poemas dedicados ao Brasil. In: Anciedade, idem, p. 57.
} 
levava de automóvel a visitar a cidade, só me fallava das Avenidas Novas, do Theatro Municipal, dos novos hoteis que estavam a construir-se, dos melhoramentos que iam fazer-se" (1913: 25).

A certo momento da conversa, Barros não se conteve e perguntou quando é que Ihe ia falar da magnifica paisagem carioca e levá-lo a conhecê-la. Feita a interpelação ouviu: "Ah! Respondeu elle, sem grande enthusiasmo. V. quer ver a natureza?”. Então o "inteligentíssimo, raffiné" cicerone o levou a conhecer a Quinta da Boa Vista.

Ao que avaliou João de Barros, só era então digna de ver-se a obra realizada pelo homem: "Pedira-Ihe a natureza, a natureza extreme - e elle mostrara-me um parque, isto é, a natureza obediente ao capricho humano, amestrada, regrada, domada. Não fallei mais na Tijuca ${ }^{24}$ - e fui lá sózinho d’ahi a dias!..." (1913:26-28). Percebe-se aqui uma necessidade em se evidenciar o trabalho realizado, para além da natureza deslumbrante e seu efeito ofuscante, já deveras consagrado pela literatura e presente no imaginário sobre o país tropical.

Cabe observar que o Rio de Janeiro, o qual emergia dos relatos dos viajantes da segunda metade do XIX, não era nada glamoroso. Em grande parte, predominavam as descrições do "temor do morticínio periódico causado pela febre amarela e o desprezo pelas ruas sujas e superlotadas, pelo mau gosto e fedor de sujeira, suor e perfume dos locais públicos" (NEEDELL, 1993: 53).

O poeta deixou-se contagiar, em certa medida, pelo discurso progressista afrancesado, o qual formava uma dada cultura de elite da capital brasileira dos finais do XIX e inícios do XX. São os anos da chamada Belle Époque Tropical por Jeffrey Needell, o momento em que o "Rio civilizava-se". A cidade foi transformada, por meio de reformas urbanas e medidas de higienização, sobretudo entre 1898 e 1914.

\footnotetext{
${ }^{24}$ Atualmente, a Floresta da Tijuca (nome com origem na língua tupi, cujo significado é "água podre"), é uma das áreas integrantes do Parque Nacional da Tijuca. Trata-se de vegetação secundária, composta por espécies nativas da Mata Atlântica. Teve origem a partir do reflorestamento promovido à época do Segundo Império (1840-1889), como forma de reparar o desmatamento e preservar a água potável da então capital do Império. Ao longo do tempo, as administrações apresentaram políticas de manejo da flora, conferindo ênfase à flora nativa e também privilegiando o aspecto paisagístico. Tornou-se uma das mais importantes áreas de lazer do Rio de Janeiro, com trilhas e espaços privilegiados para prática de desporto, tais como: ciclismo, corrida e montanhismo. Aceder: www.parquedatijuca.com.br
} 
A capital carioca, o porto de entrada ao país, devia transpirar modernidade e um enquadramento estético, segundo os padrões europeus. Afinal, era a vitrine do Brasil Republicano que se queria moderno. Os jornais da época noticiavam as opiniões em torno das mudanças propostas e do movimento do "bota-abaixo" para se promover a modernização. "A elite celebrava não só o que era feito, mas também o que era desfeito" (NEEDELL, 1993: 67).

Herdeira de uma predisposição neocolonial, as elites urbanas republicanas, em aliança com as elites regionais agrícolas, dedicaram-se a mudar esta visão de atraso. Tais elites elegiam o paradigma europeu como exemplo de civilização. 0 desenvolvimento projetado pela França e a Inglaterra eram grandes referências neste cenário. Sob a presidência do paulista Rodrigues Alves, nos anos de 1902 a 1906, as principais obras foram efetuadas. O então presidente nomeou Francisco Pereira Passos (1836-1913), filho de cafeicultor que havia estudado engenharia civil e aperfeiçoado os seus conhecimentos em Paris, para governar o Rio e implementar a reforma urbana.

A construção de novas avenidas, túneis implicou no arrasamento de habitações populares consideradas anti-higiénicas ${ }^{25}$. A região central da cidade era composta pelos chamados cortiços, onde residia a classe pobre em meio à péssimas intalações de moradia. João do Rio em Alma Encantadora das Ruas (1908) consegue transmitirnos o ambiente aterrador das hospedarias ou casas de cómodos:

“... Eu tapava o nariz. A atmosfera sufocava. Mais um pavimento e arrebentaríamos. Parecia que todas as respirações subiam, envenenando as escadas e o cheiro, o fedor, um fedor fulminante, impregnava-se nas nossas próprias mãos, desprendia-se das paredes, do assoalho carcomido, do teto, dos corpos sem limpeza. Em cima, então, era a vertigem. A sala estava cheia. Já não havia divisões, tabiques, não se podia andar sem esmagar um corpo vivo.

A metade daquele gado humano trabalhava; rebentava nas descargas dos vapores, enchendo paióis de carvão, carregando fardos. Mais uma hora e acordaria para esperar no cais os batelões que a levassem ao cepo do labor, em que empedra o cérebro e rebenta os músculos" (1910²: 214).

\footnotetext{
${ }^{25}$ Alguns estudos indicam que a expulsão da população pobre do centro neste período teria dado início a formação das favelas cariocas.

${ }^{26}$ Segunda edição de Alma Encantadora das Ruas em 1910.
} 
Para além do embelezamento de praças e largos, os agentes reformadores proibiram antigas tradições, as quais faziam-se presentes desde o período imperial. Já não eram mais permitidos certos costumes qualificados de "bárbaros" ou "incultos", mediante justificativas de preservação da saúde e da boa higiene. Foram assim proibidos: a criação de porcos dentro dos limites urbanos, a venda de leite junto com o desfilar das vacas de porta em porta, cuspir no chão dos bondes (elétricos), o comércio ambulante de alimentos, a realização dos entrudos e cordões sem a autorização no Carnaval oficial, a perambulação de cães vadios, a exposição das carnes nas portas dos açougues (talhos), dentre outros (NEEDELL, 1993: 57).

Deve-se acrescentar que, aos olhos do regime republicano, os traços lusitanos e africanos eram considerados herança indesejável do Império. Sendo, portanto, uma das diretrizes presentes nas reformas urbanas o apagamento desses vestígios. Buscouse "substituir com violência a arquitetura de origem lusitana e os costumes e meios de transporte luso-africanos das ruas, mercados, praças e subúrbios do Rio de Janeiro" (Freyre, 1949, apud LIPP OLIVEIRA, 1990: 93-94).

João do Rio descrevia em 1909 uma Lisboa também afrancesada na arquitetura e nas maneiras. Relatava ainda problemas nos serviços de transporte e exposição da miséria mendicante e de pés descalços, próximos ao que se vivenciava no Rio do seu tempo. Descobria ainda uma cidade pequena e sem o "desdobramento de palacios e de grandes arterias" ${ }^{27}$ em comparação à capital brasileira.

Na sua visita à cidade do Porto, fez referência a semelhança com o Rio antigo, anterior às reformas urbanas. Identificava-a como integralmente diversa de Lisboa e com características de progenitora do Rio: "Basta lá passar uma semana para se ter certeza de que foi a gente do norte de Portugal que formou as nossas cidades e que ainda hoje fornece ao nosso movimento maior contingente[...]" (1911: 237).

O Rio de Janeiro apreciado por João de Barros emergiu deste processo de reformas. Nota-se, ainda, que o poeta assumia uma posição entusiástica e, até certo ponto diplomática, ao tecer elogios aos governantes responsáveis pela transformação da cidade:

\footnotetext{
${ }^{27}$ Portugal d' agora, 1911: 54-56.
} 
“... Construir, como há pouco notei, 3000 casas por anno, em S. Paulo; dar salubridade e conforto, n'um abrir e fechar d'olhos, ao Rio de Janeiro, como succedeu sob a presidencia do eminente Rodrigues Alves, auxiliado por homens da envergadura do dr. Lauro Muller, o actual, e inteligentissimo ministro das Relações Exteriores..." (1913: 33).

João de Barros não estava, portanto, acima das alianças políticas que se estabeleciam em prol de causas comuns. Deve-se aqui lembrar que o Ministro Lauro Muller $^{28}$ era próximo a João do Rio e foi um dos incentivadores da aproximação lusobrasileira. Tornar-se-ia apoiador oficial da revista Atlântida, publicação dirigida pelos dois Joões, a qual nos dedicaremos mais a frente.

A energia, a vontade criadora, também fazia-se presente na vida intelectual brasileira, segundo João de Barros. Para além dos elogios a produção literária, às artes e ao jornalismo, o poeta conferiu grande destaque a qualidade do ensino, sobretudo em São Paulo. Teceu muitos elogios ao sistema educacional paulistano da época: “...o governo de S. Paulo interessa-se vivamente pelo problema da instrucção. Basta dizerse que se gasta com a instrucção um quinto da despeza total do Estado" (1913: 34-35). O poeta faz tal consideração em contraposição a iniciativa pedagógica nula ou nociva do Estado Português, segundo sua análise.

$\mathrm{Na}$ altura em que pronunciou tal crítica fazia-se recente a sua passagem pelo primeiro Governo Republicano em 1910. O poeta tornou-se membro do Partido Republicano desde os tempos universitários ${ }^{29}$. Esta filiação e o facto de se ter destacado na carreira pedagógica, favoreceram a sua nomeção ao cargo de Diretor Geral do Ensino Primário, logo após a instauração da República portuguesa. Este departamento e todas as pautas relacionadas ao ensino encontravam-se submetidos ao Ministério do Interior, sob o mandato de António José de Almeida.

\footnotetext{
${ }^{28}$ No Governo de Rodrigues Alves (1902-1906), Muller foi Ministro da Indústria, Viação e Obras Públicas e um dos idealizadores da Avenida Central (atualmente, Av. Rio Branco), o mais representativo símbolo da belle époque carioca. Foi ainda Ministro das Relações Exteriores nos Governo Marechal Hermes da Fonseca (1910-1914) e Venceslau Bras (1914-1918). No entanto, renunciou ao cargo em 1917, devido aos conflitos gerados no contexto da I Guerra, cedendo às pressões em função das suas raízes alemãs.

${ }^{29}$ Cursou Direito na Universidade de Coimbra entre 1898 e 1904, no entanto optou por seguir a carreira do Magistério. Concorreu, em 1905, ao cargo de professor do ensino liceal nas disciplinas de Português e Francês, tendo obtido o primeiro lugar na classificação (ARAÚJO, 2004: 15).
} 
Após assumir o cargo, o pedagogo tomou algumas medidas importantes, dentre as quais: a abolição do ensino religioso nas escolas primárias e normais primárias, o apoio a ação alfabetizadora das escolas móveis ${ }^{30}$ e a criação de estações escolares ao ar livre (ARAÚJO, 2004: 15).

Na sua primeira obra sobre a questão educacional (A Escola e o Futuro, 1908), o poeta explicitou os seus conhecimentos sobre as novas correntes pedagógicas e a ênfase dada ao papel da criança na sociedade. O interesse pelas crianças no alvorecer do século XX, justificava-se "pela certeza do Futuro que elas representam, mesmo se elas ainda não tem consciência disso" (ARAÚJO, 2004: 22).

João de Barros ao pensar um novo encaminhamento para o ensino português, orientava-se pelas modernas teorias da época, sobretudo o movimento da Educação Nova dos fins do século XIX. O poeta teve contato com a vanguarda pedagógica na viagem de estudos, realizada em missão oficial ${ }^{31}$, quando visitou diferentes estabelecimentos europeus de educação primária e secundária, no ano de 1907. Grande parte desta experiência e observações foram relatadas na Escola e o Futuro.

A Educação Nova fundamentava-se nos estudos positivistas no âmbito da Psicologia infantil. Neste sentido, a criança não era vista como um adulto em miniatura, conforme a Escola tradicional, mas com características específicas e evolução própria. Priorizava-se aqui o desenvolvimento progressivo da autonomia infantil (ESTEVES DE OLIVEIRA, 2001: 151).

Em síntese, esta corrente defendia um processo de aprendizagem centrado nos interesses e necessidades dos educandos, na cooperação e na resolução de problemas práticos em contraposição a transmissão de saberes. Privilegiava-se ainda a experiência e a observação, com vistas à utilidade para a vida prática (idem: 152-153).

\footnotetext{
30 Implantadas pela República a partir de 1913, as Escolas Móveis destinavam-se a suprir a falta de estabelecimentos de ensino em várias localidades do país. As mesmas visavam, sobretudo, combater o analfabetismo dos adultos (SERRÃO, 1981: 29).

${ }^{31}$ Com o intuito de se promover uma reforma da instrução pública, a Presidência do Conselho de Ministros da época fomentou um concurso de bolsas de estudos para professores que se dispusessem a realizar viagens e recolher informações sobre os métodos de ensino em diferentes países europeus, tais como: Alemanha, Inglaterra, França, Áustria, Suiça, Bélgica, Suécia e Itália (ARAÚJO, 2004: 12).
} 
Este movimento deve ainda ser pensado à luz do contexto em que foi gestado. Surgiu no período de implantação dos regimes republicanos e democráticos em vários países. Essas novas realidades necessitavam de formar cidadãos ativos, essenciais para a construção das democracias.

Uma outra questão importante, a qual sobressai no pensamento do escritor acerca do ensino é a interação entre o aluno e a natureza. Isto aparece na sua reflexão sobre a energia brasileira. Dizia não querer provar que a relação dos brasileiros com a terra constituía-se no principal elemento formador da sua energia. No entanto, desempenhava um papel importante no modo de ser brasileiro (BARROS, 1913: 31).

Para fundamentar a sua argumentação, citava o exemplo de um engenheiro brasileiro que se propôs a construir um caminho de ferro num local tão perigoso, que os colegas de profissão estrangeiros recusaram-se a segui-lo. Nas palavras de João de Barros: “É a natureza exaltando, educando o homem n'uma escola de força e de ousadia, chamando-o para novas conquistas, desafiando-lhe a coragem, tornando maior a nossa sêde insaciavel de dominar, de submeter a Terra" (idem: 31-32).

A ênfase na relação educando-natureza teve como base o programa desenvolvido por um educador Belga, Jean-François Eslander ${ }^{32}$, o qual partilhou as suas ideias com o poeta durante a viagem de estudo. Segundo este modelo, na chamada primeira educação, o aluno devia interagir com o meio ambiente (uma quinta, um jardim ou um pomar) e a partir desta interação dar-se-ia o aprendizado. Nesta fase, o papel do professor seria o de fazer observações e suscitar perguntas a partir das práticas desenvolvidas. Somente na segunda educação a intervenção do docente tornar-se-ia gradualmente maior. O educador começaria a orientar os alunos, como expositor ou auxiliar, estabelecendo relações entre os saberes adquiridos, elucidando-os acerca da necessidade do livro (ESTEVES DE OLIVEIRA, 2001: 159).

A política educativa dos primeiros governos republicanos voltou-se para alguns problemas, considerados fulcrais, sendo os mesmos: o analfabetismo, a escolarização, a formação e o estatuto do professores. A ênfase das reformas educativas tiveram

\footnotetext{
32 Jean-François Eslander (1865-1948) foi autor de obras relevantes, tais como: L'Education ou Point de Vue Sociologique (1898) e L'Ecole Nouvelle (1904).
} 
como alvo o ensino primário, tendo em vista o combate ao analfabetismo da população portuguesa. Algumas leituras de época ${ }^{33}$ apontam que o analfabetismo atingia cerca de $80 \%$ da sociedade dos fins do século XIX.

O comprometimento de João de Barros com a questão educacional e suas observações sobre a mesma no Brasil, acabou por ocupar um considerável espaço na obra inaugural da Campanha Atlântica.

Uma outra questão discutida pelo poeta, em decorrência da sua primeira viagem, referia-se aos critérios dispensados ao ensino da língua portuguesa. É um tema curioso, tendo em vista que nos dias correntes a implementação do novo acordo ortográfico entre os países falantes de Língua Portuguesa encontra-se em debate. Torna-se, portanto, mais interessante ter em perspectiva esta visão de época.

Neste sentido, identificava diferenças entre São Paulo e Rio. Na primeira cidade havia, segundo João de Barros, uma preocupação com o ensino do português clássico e puro: ... "o cuidado não affrouxa nunca. Mesmo a collocação dos pronomes, que em geral, no Brazil é diversa d'aquella que nós lhe damos, em S. Paulo é rigorosamente exigido que a façam á nossa maneira" (A Energia Brasileira, 1913: 44-45).

Contudo, no Rio de Janeiro não se impunha o mesmo rigor. Tal diferença, aos olhos do escritor, justificava-se pelo facto de que em São Paulo a língua era considerada um agente indispensável de nacionalização. Havia preocupações em função da influência das colónias estrangeiras, sobretudo a Italiana, mas não só, bastante ativa na cidade e em algumas regiões do país. O poeta cita partes do discurso proferido pelo então Diretor da Escola Normal de São Paulo, o pedagogo Oscar Thompson, na qual estabelecia considerações acerca da relação entre a educação e o elemento cultural estrangeiro:

“... Mas queremos a escola que se opponha á formação d'uma pequena Allemanha no sul do nosso paiz, de um pequeno Portugal no Rio e de uma pequena Italia em S. Paulo. Sim, essa escola, como a queremos, jamais permittirá a dispersão da physionomia nacional; e, do nosso passado, quer nos dias de paz, quer nos dias de guerra,

\footnotetext{
33 José Simões Dias. A Escola Primária em Portugal (1897), apud ESTEVES DE OLIVEIRA, 2001: 186.
} 
tirará grandes ensinamentos para formar o espírito da nova geração brazileira" (idem: 44).

Daí a necessidade da ênfase no ensino da língua portuguesa às crianças estrangeiras. O poeta fazia ainda uma ressalva acerca do discurso de Thompson opondo-se a ideia da formação de um "pequeno Portugal no Rio". Não deveria haver receio deste tipo quanto ao português, visto que como o brasileiro é um "cidadão da terra onde habita" (ibidem: 43). A partir desta premissa, justificava o menor rigor quanto ao ensino do português no Rio, pois lá não se temia a grande influência estrangeira a combater. No seu entender, a colónia portuguesa não era vista como estrangeira (idem, ibid.: 44).

Alguns estudos, os quais abordam as representações criadas em torno do imigrante português e da colónia portuguesa no Rio da primeira metade do século XX, nos auxiliam a problematizar tal visão. Neste sentido, em Aqui também é Portugal, Heloísa Paulo ${ }^{34}$ considera que o imigrante português distinguia-se dos demais por falar a mesma língua do país de acolhimento, apesar de manter-se como um grupo próprio. Contudo, acerca da tão propagada imagem dos traços culturais partilhados afirma que estes, muitas vezes, "só existentes nas argumentações dos discursos diplomáticos, o português, como os outros emigrantes, sofre o estigma de ser diferente, de estar em terra alheia" (PAULO, 2000: 18).

Jorge Alves, ao analisar o processo de imigração portuguesa e a vertente xenófoba de alguns grupos da sociedade brasileira, traça comentários acerca de tais imagens. Por um lado, havia uma perceção em torno do português como o comerciante bronco, analfabeto e adulterador do peso, a qual tornou-se um lugarcomum na imprensa anti-lusitana, especialmente nos momentos de agravamento da crise social (1999: 40).

As origens de um olhar ambíguo e dos estereótipos criados em torno dos imigrantes lusos remontavam a relação colonizador-colonizado e ao processo de

\footnotetext{
${ }^{34}$ Nesta obra a autora busca por meio do estudo da colónia portuguesa radicada no Rio de Janeiro, recuperar a trajetória da adesão dos emigrantes ao salazarismo. Para isto, lança mão de uma análise mais ampla da proposta ideológica do Estado Novo português e da própria realidade do emigrante. Embora o período recortado seja o pós 1930, em algumas partes do trabalho Paulo remete-se às décadas anteriores.
} 
formação da identidade nacional brasileira. Ao longo do século XIX, sobretudo no pós independência, a ambiguidade no que concernia a Portugal e à cultura portuguesa fortaleceu-se. Nesse processo, os estereótipos, tais como, bronco, inculto, tacanho ganhavam força em decorrência da crescente imigração portuguesa.

Esta visão convivia com uma outra construída pela elite da colónia portuguesa do Rio de Janeiro; a do português obediente, trabalhador, apolítico, ou seja, a do imigrante ideal para a ordem social vigente ${ }^{35}$. Foram produzidas obras ${ }^{36}$, nas quais legitimou-se um discurso da permanência e continuidade históricas entre os dois países.

Segundo análise de Jorge Alves, a colónia não formava um bloco monolítico de interesses. Existiam clivagens económicas, políticas e sociais. Para além disso, a elite da comunidade imigrante portuguesa encontrava-se dividida por disputas que remetiam ao contexto conturbado do país natal. Num primeiro momento, devido ao acirramento da campanha republicana, mais tarde em função da crise da I República portuguesa, dentre outras questões (1999: 70).

Difundiu-se assim, por parte da colónia, uma leitura una em torno do imigrante português, minimizando-se os conflitos e as diferenças. Reforçava-se a ideia comum de que eram todos expatriados, como se não houvesse diferenças entre uma elite rica e um grande contingente de trabalhadores pobres. Nesta imagem, "o português ligavase por laços históricos e afetivos ao Brasil, não sendo, portanto, um estrangeiro" (idem, 1999: 101).

A partir disto, torna-se claro que a visão de João de Barros acerca da perceção em torno do imigrante português na então capital brasileira filiava-se a esta matriz.

\footnotetext{
${ }^{35}$ Esta imagem do português apolítico foi incorporada, em certa medida, por uma parte da historiografia brasileira que se dedicou a História do Movimento Operário na I República. Daí emergia o mito do protagonismo dos imigrantes de outras nacionalidades (sobretudo, dos italianos e dos espanhóis) em detrimento do trabalhador português sempre ordeiro. Estudos mais recentes problematizaram tal leitura e recuperaram o papel do imigrante português no mundo do trabalho. Estas interpretações destacaram a atuação lusa nos movimentos operários e sindicais, tais como os imigrantes de outras nacionalidades (conf., MARTINHO, 2002: 199-239).

${ }^{36}$ Carlos Malheiro Dias (org.). História da Colonização Portuguesa do Brasil. Rio de Janeiro: Lit. Ferreira Pinto, 1921.
} 
Prevalecia no seu discurso a ideia da afetividade, dos laços históricos e da proximidade cultural entre os dois países.

Para situarmos melhor este debate, é importante termos em mente que a elite intelectual brasileira repensava a ideia de nação entre os fins do XIX e primeiras décadas do século XX. Nesse sentido, pode-se situar duas grandes interpretações sobre o Brasil no início do período republicano. Segundo a historiadora Lúcia Lipp Oliveira, havia dois modelos de identidade nacional em disputa. Um deles avaliava positivamente o passado colonial e imperial. Defendia a excelência das tradições, fruto da colonização portuguesa e da ação da Igreja Católica. O outro modelo via na fundação da República uma rutura necessária com o passado português, corporificado no regime monárquico (1990: 23).

A versão que reconhecia a importância da tradição portuguesa como formadora da identidade brasileira, reforçava os elementos culturais comuns e criava espaço para o discurso do luso-brasilismo, luso-brasileirismo ou luso-brasilidade enunciado por intelectuais de ambos os países.

O Rio de Janeiro era o centro de atração e de propagação de tudo que se pretendia novo, o locus privilegiado da consagração de autores. Acrescentemos ainda, um dos principais destinos da emigração portuguesa para o Brasil onde constituiu-se uma influente elite política, comercial e intelectual derivada da colónia lusa da cidade. Este último segmento exerceu um considerável protagonismo na vida cultural brasileira do período, ao fundar jornais, revistas e gabinetes literários. Pela mediação de tais agentes, formaram-se redes de sociabilidade entre os intelectuais brasileiros e portugueses nas duas margens do Atlântico (ALVES, 2009: 13).

Entretanto, em confronto com a corrente intelectual lusobrasilista havia os intelectuais de uma vertente nacionalista radical com discursos lusófobos. Tal posicionamento era mobilizado contra a propagada influência política e económica da elite portuguesa nos rumos do país. 
Do ponto de vista das relações de trabalho ${ }^{37}$, num mercado urbano ainda em constituição, os conflitos étnicos estiveram presentes no decorrer da I República. 0 preconceito no que se referia ao trabalhador nacional impunha-se como marca da herança escravocrata. Ao imigrante europeu era dada a preferência, por ser considerado superior culturalmente e isto gerava ressentimento por parte do trabalhador brasileiro (MARTINHO, 2002: 207).

Podemos mensurar o impacto destas tensões na capital carioca, onde o imigrante português era mais numeroso. Estes fatores também contribuíram para as manifestações lusófobas que, muitas vezes, se articulavam à crise crónica do mercado de trabalho e às péssimas condições de vida da imensa maioria da população.

Retomando o percurso do nosso poeta, cabe acrescentar que a estreia de João de Barros na vida política do seu país não teve o melhor desfecho, pois culminou no pedido de exoneração do cargo de Diretor Geral do Ensino Primário. Esta atitude foi motivada pela sua insatisfação com o texto da Reforma do Ensino Primário.

Na sua origem o projeto de reforma tinha sido atribuído pelo então Ministro António José de Almeida a João de Barros e João de Deus Ramos ${ }^{38}$. Este último era amigo do poeta desde os tempos da Universidade, também dedicado à questão educacional e, na altura, Chefe de Repartição Pedagógica. Reuniram-se então a um

37 Sobre esta temática conferir CHALHOUB, Sidney. Trabalho, Lar e Botequim: o cotidiano dos trabalhadores no Rio de Janeiro da belle époque. 2 ed. Campinas; São Paulo: Editora da Unicamp, 2001. Análise mais panorâmica da constituição da classe trabalhadora no Brasil em GOMES, Angela de Castro. A Invenção do Trabalhismo. 3a ed., Rio de Janeiro: Editora FGV, 2005.

${ }^{38}$ João de Deus Ramos Júnior (1878-1953) foi pedagogo, escritor de fábulas e político português. Filho do também pedagogo e reconhecido poeta lírico João de Deus (1830-1896). Dedicou-se a dar continuidade ao trabalho pedagógico iniciado pelo pai. Cursou Direito em Coimbra, onde estreitou amizade com João de Barros. Concluiu, em 1902, os seus estudos e publicou Os altos princípios do método João de Deus. Nos anos seguintes iniciou uma série de conferências pedagógicas e propaganda do Método de Leitura e Escolas Móveis por todo o país. Em 1908, realizou viagem pela Europa, sobretudo à França e à Suíça, com o propósito de observar o funcionamento dos Jardins de Infância. Regressou à Portugal com a ideia de criar Jardins-Escolas, pautando-se nos métodos apreendidos, mas adaptando-os à realidade portuguesa. Ao longo da sua vida desenvolveu várias atividades em prol da educação, tais como a implementação dos jardins-escolas em várias cidades: Coimbra (1911), Alcobaça e Figueira da Foz (1914), Lisboa (1917), Alhadas (1927), Leiria e Castelo Branco (1936), Viseu (1943), Mortágua e Chaves (1948), Porto (1952). "Os traços fundamentais que caracterizavam o ensino nos Jardins-Escolas João de Deus são os que ainda hoje os sustêm: a intenção social (preocupação pelo desenvolvimento das classes mais desfavorecidas); o culto pelos valores nacionais; a expressão gráficopictórica e verbal. A filosofia pedagógica pretende desenvolver a ligação da criança ao meio. A aprendizagem tem que ser feita pelo raciocínio e não por aquisições de noções verbalizantes. 0 ensino da leitura inicia-se aos cinco anos". In: http://www.joaodeus.com/associacao/biografias.asp?id=3 . 
grupo mais amplo de estudiosos e propuseram o programa de reforma. Entretanto, segundo depoimentos da época, o texto aprovado e publicado no Diário do Governo (Março de 1911) não correspondia ao original (ARAÚJO, 2004: 17). Bastante contrariado diante das alterações, o pedagogo solicitou dispensa da Direção Geral do Ensino Primário.

O impasse gerou a troca de farpas entre António José de Almeida e João de Barros via imprensa. Entretanto, chamou-nos a atenção a carta enviada pelo Ministro ao sogro do poeta, o escritor Teixeira de Queirós (Bento Moreno) ${ }^{39}$, acerca do pedido de demissão do genro. Assim dizia: "Os rapazes de agora querem impor uma tutella as nossas ideias, mesmo áquellas que só nós assignamos e em cuja defeza seremos abandonados, se alguem nos atacar" (AZEVEDO, 1982: 36). Numa atitude paternalista, António José de Almeida diz ao escritor que poderia relevar o pedido de exoneração, caso João de Barros reconsiderasse a sua posição.

A argumentação do então Ministro reflete, de certa maneira, as diferenças entre as gerações republicanas. Anuncia ainda os conflitos entre as fações republicanas, que marcaram a instabilidade política de toda a Primeira República. Logo após este desentendimento, João de Barros filiou-se ao Partido Democrático, liderado por Afonso Costa, considerado a vertente mais radical do novo regime.

Nesta parte inicial, buscamos situar as impressões do poeta geradas pela sua primeira estadia em terras brasileiras. Optamos por uma problematização a partir dos temas mais relevantes, ao nosso ver, levantados pelo autor. Este será o fio condutor da narrativa que pretendemos desenvolver ao longo do trabalho. A seguir, buscaremos discutir as visões propostas na obra O Sentido do Atlântico (1921), publicada após a segunda viagem do nosso personagem ao Brasil, realizada em 1920.

\section{I.2. A aproximação luso-brasileira: nacionalismos e nativismos}

\footnotetext{
39 João de Barros casou-se em 1903 com D. Raquel Teixeira de Queirós (1880-?), filha do romancista Francisco Teixeira de Queirós (1848-1919). Teve dois filhos; Henrique Teixeira de Queirós de Barros (1904-2000), Paulo Teixeira de Queirós de Barros (1908-?) e uma filha; Teresa Teixeira Queirós de Barros (1906-1970). O primogénito, também professor, foi Ministro de Estado e Presidente da Assembleia Constituinte após a Revolução de 25 de Abril de 1974.
} 
Em O Sentido do Atlântico, quarta obra da campanha luso-brasileira ${ }^{40}$, a visão de João de Barros sobre o Brasil e a proximidade com Portugal demarca-se da conferência inaugural pelo tom mais pragmático, saindo digamos daquele estado de enamoramento para uma relação mais amadurecida. Consideramos aprofundar as questões desenvolvidas nesta obra, por ser um texto pós-viagem ao Brasil, tal como ocorrido em A Energia Brasileira (1913).

Como epígrafes João de Barros escolheu textos de dois poetas e homens públicos ilustres das letras portuguesa e brasileira: Guerra Junqueiro (1850-1923) e Olavo Bilac (1865-1918). Ambos desempenharam papéis relevantes enquanto pensadores das respectivas realidades nacionais e no campo da militância republicananacionalista. As citações escolhidas despertam a nossa atenção para importantes representações acerca das relações histórico-culturais entre Portugal e Brasil.

Sendo assim, Barros evocou a imagem criada por Guerra Junqueiro, a qual reforçava o imaginário de Portugal como gerador de nações: "O Brasil não chegou a ser uma colonia. Foi logo nação, foi logo patria: - a nova Patria Portuguesa, com novos herois e novos descobridores, com novos santos e novos orfeus, novas enxadas e novas liras $(1916)^{41 " \prime}$.

Quanto ao consagrado poeta brasileiro Olavo Bilac, importante defensor de uma das vertentes nacionalistas das primeiras décadas do século $X X$, da qual trataremos mais adiante, selecionou:

"Portugueses, acompanhae com o vosso cuidado e o vosso carinho o trabalho de nacionalisação, de defesa física e moral, que ora empreendemos no Brasil. O premio dessa campanha não será sómente conquistado por nós: _ será vosso tambem... Porque, se nos batemos pela nossa vida e pela nossa hora, tambem nos batemos pelo vosso nome e pela vossa gloria. E venceremos! D'aqui a cem anos, cem milhões de brasileiros abençoarão o nosso esforço, e cada um dêsses brasileiros dirá à Patria, como hoje eu digo, a oração

\footnotetext{
40 Antes foram ainda publicadas Caminho da Atlântida: uma campanha luso-brasileira (1918) e $A$ aproximação luso-brasileira e a paz (1919). A primeira será analisada no segundo capítulo, quando nos dedicaremos aos temas da Revista Atlântida. Já a discussão presente em A aproximação luso-brasileira e a paz vai ser incorporada à medida que nos auxiliar no diálogo com O Sentido do Atlântico.

41 "Brasil-Portugal", discurso pronunciado na sessão dedicada à Olavo Bilac, em 2 de Abril de 1916. In: JUNQUEIRO, Guerra. Prosas Dispersas. Porto: Chardron, 1921: 109.
} 
fervorosa do seu amôr e de sua fé, articulada na suave e poderosa língua portuguesa" (epígrafe, BARROS, Sentido do Atlântico, 1921).

A ideia de "sentido do Atlântico", segundo Barros, remetia ao significado de expansão universal que todos os países de extensa orla marítima, tais como, Portugal e Brasil possuíam. Tratava-se do mar da energia e das aspirações brasileira e portuguesa. "É o sentido da tradição portuguesa, visto que Portugal é um país com todas as suas janelas voltadas para essa maior estrada do mundo, e que o nucleo inicial da população lusitana se compõe de gente navegadora, anterior, nas suas viagens pelo mar, aos gregos e aos fenicios" (Apêndice, 1921: 249-250). Esta definição foi evocada em conferência aos inspetores escolares brasileiros, realizada em Maio ${ }^{42}$ de 1920 na Biblioteca Nacional do Rio de Janeiro, provavelmente, ao final da estadia do escritor no país.

No período de oito anos (1912 a 1920), datas que marcaram a primeira e segunda viagens de João de Barros no Brasil, grandes acontecimentos e mudanças ocorreram nas realidades mundiais. A I Guerra foi um desses divisores de água, produzindo impactos no mundo, com desdobramentos nas sociedades brasileira e portuguesa.

Dizia João de Barros que a defesa sentimental da aproximação entre Portugal e Brasil devia apoiar-se “... na existencia de tradições comuns, na fraternidade do sangue, nos costumes identicos, e na uniformidade da lingua..." (1921: 23). As questões que remetiam a uma tradição cultural partilhada não foram abandonadas pelo autor, no entanto, alguns fatores conjunturais mereceram maior ênfase em $O$ Sentido do Atlântico.

O poeta qualificou como esparsas e tímidas as tentativas oficiais de estreitamento das relações entre os dois países. Nesse sentido, equacionou os principais entraves para a concretização de possíveis acordos luso-brasileiros:

"Umas vezes, ergue-se a imagem assustadora da colonia, cujos melindres e delicadezas é preciso respeitar. Outras vezes, o monstro da campanha nativista no Brasil faz recuar e empalidecer as melhores e mais carinhosas intenções. Outras ainda, o problema da emigração

\footnotetext{
42 Publicada no jornal carioca O Paiz, de 11 de Junho de 1920. In: Apêndice de O Sentido do Atlântico.
} 
aparece como um assunto em que não se pode falar, sob pena de nos malquistarmos com a Republica irmã..." (1921: 55).

Já não era possível ignorar os ecos da campanha nacionalista brasileira, que em determinados segmentos assumiam uma posição lusófoba exasperada. Somavam-se a esse fator, a imagem conservadora da colónia portuguesa com forte inclinação monárquica e a as opiniões críticas no que tangia a emigração lusa para o Brasil.

Na I República brasileira (1889-1930) foram elaboradas novas interpretações acerca da questão da nação, do nacionalismo e da identidade nacional (LIPPI OLIVEIRA: 1990). Conforme dito anteriormente, a herança cultural e presença portuguesa foram pensadas entre variantes positivas (lusofilia) e também negativas (lusofobia). Essas múltiplas leituras estiveram em confronto, assumindo maiores impactos em determinados contextos.

Segundo Jorge Alves, em tese que busca analisar as relações culturais lusobrasileiras, com destaque para o percurso de Carlos Malheiro Dias nesse quadro, a lusofobia possuía raízes profundas motivadas pelo descontentamento económico e pela componente mental. Os agravos económicos justificavam-se, em grande parte, pela presença massiva e desigual do imigrante português no mercado de trabalho urbano. Do lado mental, construiu-se uma visão de Portugal como "a imagem antípoda do nacional", incorporada por setores significativos da população brasileira (2009: 24).

As diferentes leituras acerca da presença portuguesa no Brasil fazem parte de um longo e controverso processo histórico de construção de uma identidade nacional brasileira. Grande parte da historiografia situou como importantes momentos deste processo: o movimento de independência (1822), a transferência da corte para o Rio de Janeiro (1808) até os inícios do século XX.

Gladys Sabina Ribeiro revisitou o Primeiro Reinado Brasileiro (1822-1831), como forma de problematizar o processo de elaboração dos significados do "ser brasileiro" e do "ser português" e investigar as raízes do sentimento antilusitano. Com esse propósito, a historiadora recuperou as diversas interpretações sobre os conflitos entre brasileiros e portugueses, as quais foram impressas pela historiografia que se dedicou ao tema da emancipação política (1997: 23). 
O grande contributo deste trabalho encontra-se no facto da autora entender o antilusitanismo como um fenómeno de raízes mais profundas, vinculado ao mercado de trabalho, às questões étnico-raciais e à luta pela obtenção da liberdade pelos segmentos populares. Ampliou-se a leitura para além dos conflitos de nacionalidade, produzidos no contexto das disputas de interesses entre classes proprietárias dominantes da colónia e da metrópole no processo da independência brasileira. Visão esta matizada por uma parte da historiografia sobre o período.

Essas breves referências nos auxiliam a historicizar a constituição de um imaginário anti-português, com vistas a compreendermos como esse discurso foi reelaborado pelas correntes nacionalistas dos finais da I Guerra e início dos anos vinte, tendo como palco principal a cidade do Rio de Janeiro.

Com o advento da I Guerra e todas as questões despoletadas pelo conflito, como a diminuição do mito da superioridade europeia, observou-se uma mudança de postura por parte dos intelectuais brasileiros. Essa mudança de perspectiva refletiu-se no conteúdo das publicações (livros, jornais e revistas). Deixou-se de lado o tom mundano e despreocupado e sobressaíram os discursos de inquietação com os rumos do país. Questionava-se, em diferentes vozes, qual a posição do Brasil em meio a um contexto de acirrada disputa entre as grandes potências europeias e suas políticas imperialistas.

Nesse cenário, articularam-se algumas tendências nacionalistas militantes no país. Em linhas gerais, assumiram duas vertentes: uma direcionada à defesa do serviço militar e a construção de uma consciência cívico-patriótica, configurada na Liga de Defesa Nacional e na Liga Nacionalista de São Paulo. A outra, encontrava-se mais próxima a um nacionalismo de direita, crítico ao liberalismo e aos estrangeirismos. Constituiu-se a partir do Rio de Janeiro e organizou-se por meio de dois movimentos: a Propaganda Nativista e a Ação Social Nacionalista.

A Liga da Defesa Nacional foi fundada em 7 de setembro de 1916, data em que se comemora a independência do Brasil, na Biblioteca Nacional do Rio de Janeiro. O 
poeta Olavo Bilac, após várias conferências configurando uma jornada nacionalista, foi um dos criadores da entidade ${ }^{43}$.

Segundo Lippi Oliveira, Bilac encontrava-se entre os autores que compreendiam os novos tempos. Ainda nas suas crónicas de 1905 (revista Kosmos ${ }^{44}$ ), defendia a educação primária e o serviço militar obrigatórios. Na batalha pelo civismo, o escritor mobilizou setores sociais em torno da Liga Brasileira pelos Aliados no início da Primeira Guerra. "Sua proposta de salvação nacional passava pelo serviço militar obrigatório ${ }^{45}$, visto como instrumento de formação de brasileiros conscientes e dignos que conduziria ao triunfo da democracia" (1990: 120).

Entretanto, o poeta não era militarista, mas acreditava que o exército cumpria um papel civilizador e coesivo diante da falta de uma organização da sociedade civil. A incorporação generalizada da população à instituição possibilitava ao cidadão uma formação elementar, garantindo o domínio da língua portuguesa, a introdução dos hábitos regulares de higiene e a educação fundamental.

Em discurso proferido na Academia das Ciências de Lisboa, em Março de 1916, posteriormente publicado no livro A defesa Nacional (1917), Bilac definiu o seu nacionalismo como tradicionalista:

\footnotetext{
${ }^{43}$ Dentre outros nomes de peso nas esferas política, jurídica, diplomática e literária brasileira da época participaram da fundação da Liga: Pedro Lessa (1859-1921), Miguel Calmon (1879-1935), Wenceslau Braz (1868-1966), Rui Barbosa (1849-1923), Coelho Neto (1864-1934), João Pandiá Calógeras (18701934) e o general Caetano de Farias (1855-1920). Atualmente, a Liga da Defesa Nacional possui representações em alguns Estados brasileiros, tais como: Brasília (órgão central), Rio Grande do Sul, Santa Catarina, Paraná, Rio de Janeiro, Ceará, Maranhão, Piauí, São Paulo e Amazonas. A organização define como principais diretrizes: "defender a integridade territorial e a integridade nacional; promover a formação moral da pessoa humana; valorizar a cultura nacional; difundir a educação cívica; incentivar o estudo de nossa história e de nossas tradições; incentivar a adoção de uma bandeira nacional em cada escola, sindicato e entidade de classe; realizar anualmente a corrida do fogo simbólico da pátria, entre outras finalidades" (RANQUETAT JÚNIOR, 2011: 13-14).

${ }^{44}$ Publicada no Rio de Janeiro entre 1904 e 1909, totalizando 64 números. Inicialmente, teve como diretor Mário Behring, no entanto, o mesmo afastou-se em 1905 e o posto foi assumido por Jorge Schmidt. A revista foi lançada no burburinho das reformas urbanas que modificaram a então capital do país e teve como principais colaboradores Olavo Bilac e Coelho Neto (DIMAS, 1983).

${ }^{45}$ Cabe aqui algumas considerações acerca do papel do serviço militar ao longo do Império e da I República brasileira. Na época em questão, o serviço militar constituiu um dos únicos meios de ascensão social para a classe pobre. Durante a monarquia impingia-se o recrutamento forçado ou voluntário. 0 sorteio para o serviço foi regulamentado por uma lei em 1874, a qual não foi aplicada. Após exaustivos debates, foi aprovada a Lei no 1860 em 1908, esta regulava o alistamento, o sorteio e, assim, reorganizava o exército. No entanto, o primeiro sorteio realizou-se somente em Dezembro de 1916, com a presença do poeta Olavo Bilac (Celso Castro apud RANQUETAT JÚNIOR, 2011: 13).
} 
“... Isto explica também o vivo desejo com que procurei a honra e o júbilo de pertencer á vossa companhia. Querendo ser vosso, quiz, de modo mais forte, incorporar-me á vossa cultura e integrar-me no nosso passado. Este meu tradicionalismo não é incompatível com o meu nacionalismo. Nacionalista ardente, e não nativista, tenho um patriotismo com pergaminhos e brazões. E a minha attitude, aqui, é a mesma que me governa no Brazil"(1917: 39).

A questão da educação cívica e da incorporação de valores patrióticos pela sociedade brasileira constituía importante arma para manutenção da unidade políticaterritorial aos olhos do poeta. Essa preocupação teve como pano de fundo a instabilidade política ${ }^{46}$ vivenciada no início do regime republicano:

“Este é o meu terror. Porque sem unidade não ha pátria. Quatrocentos annos de esperança e de tortura fizeram esta nação, dada á humanidade pela continuação de infinitas acções generosas: pelo esforço de um pequenino povo, menos de dois milhões de almas, em uma estreita faixa de terra, - descobrindo, povoando, explorando, artilhando, defendendo mais de seis mil kilometros d'esta costa; pelo impeto das bandeiras e pela bondade dos apostolados, desbravando as selvas, as águas e as almas; pelo sangue dos filhos e dos netos dos povoadores, derramado em prol do patrimônio; pelo suor e pelas lagrimas de uma raça martyr, arrancando do solo bruto a riqueza, a felicidade e o luxo; pelo heroísmo de successivas gerações, combatendo pela liberdade, pela integridade, pela justiça e pela gloria... E' horrível pensar que esta esplendida construcção de quatro séculos possa ser desmantelada pela inércia, pela ignorância, pela preguiça moral, pelo egoísmo! ${ }^{47 " \prime}$ (BILAC, 1917: 23).

A citação é longa, no entanto contém elementos importantes para a nossa discussão. Temos, a partir dessas considerações de Bilac, uma visão enaltecedora da colonização portuguesa e do seu contributo para a preservação da unidade brasileira. Visão essa partilhada por segmentos da intelectualidade portuguesa e brasileira do período. Cabe acrescentar, que o poeta recebeu muitas homenagens de

\footnotetext{
46 "Durante quase dez anos de República, as agitações se sucediam na capital, havia guerra civil nos estados do Sul, percebiam-se riscos de fragmentação do país, a economia estava ameaçada pela crise do mercado do café e pelas dificuldades de administrar a dívida externa. Para os que controlavam o setor mais poderoso da economia (exportação) e para os que se preocupavam em manter o país unido, tornava-se urgente acabar com a instabilidade política" (CARVALHO, José Murilo de, 2006: 31).

47 Conferência realizada no banquete oferecido pelo Exército, no edifício do Clube Militar (6 de Novembro de 1915) no Rio de Janeiro, publicada em A Defesa Nacional.
} 
personalidades portuguesas, quando da sua estadia em Lisboa em 1916, além de considerável destaque na imprensa.

João de Barros, ao equacionar os entraves à aproximação luso-brasileira, referiu-se à campanha nativista. Essa foi outra tendência nacionalista com bastante visibilidade e influência na época. O nacionalismo militante de direita teve expressão em duas organizações: a Propaganda Nativista (1919) e a Ação Social Nacionalista (1920).

Essas entidades e os grupos fundadores das mesmas aproximavam-se do nacionalismo jacobino ${ }^{48}$, que ganhou força no Governo do Marechal Floriano Peixoto (1891-1894), numa fase de implantação e consolidação da República. A este líder político e grande patriota ${ }^{49}$, conforme apreciação do grupo, prestaram homenagens e tinham como traço marcante o mesmo anti-lusitanismo dos seus antecessores.

Álvaro Bomílcar (1874-1957), escritor, jornalista e poeta, foi um dos principais expoentes do movimento nacionalista radical e nativista da época. O escritor Mário Linhares (1889-1965) em artigo sobre o percurso de Bomílcar, referiu que "em todos os [seus] livros de construção social, há aquela alma impertérrita e abnegada de patriota que quer um Brasil autônomo, vivendo por si mesmo, liberto da tutela econômica estrangeira ou quaisquer outros liames que lhe embaracem os movimentos de ação (1957: 227)".

É importante acrescentar, que Bomílcar foi estudante na Escola Militar nos agitados anos do Governo Floriano Peixoto (1891-1894). Conservou fortes impressões

\footnotetext{
${ }^{48} \mathrm{O}$ jacobinismo manifestou-se como um movimento político de composição social heterogénea, respaldado por um discurso essencialmente militar-positivista, com forte atuação nos anos de 1893 a 1897. Embora tenha limites cronológicos definidos, segundo Queiroz, alguns dos elementos marcantes do seu discurso, como a lusofobia, o republicanismo e antimonarquismo virulentos, são-lhe anteriores ou permanecem vivos após o período de atuação do movimento. Devido ao esse facto da indissociação entre ação e pensamento, o qual caracterizou o jacobinismo, não há consenso historiográfico quanto ao seu surgimento e fracasso. É, portanto, um conjunto de elementos (lusofobia, republicanismo, antimonarquismo) que definem o movimento acrescido do florianismo (culto à personalidade do Marechal Floriano Peixoto), característica inovadora que permite situá-lo no tempo e conferir-lhe especificidade (QUEIROZ, 1986: 263-264).

49 Dedicatória de Álvaro Bomílcar, fundador da Campanha Nativista, em destaque no livro A política no Brasil ou o Nacionalismo Radical (1920): “À memória do consolidador da República, Marechal Floriano Peixoto, heróe modesto, mentalidade culta, patriota inexcedível, que se esforçou para dar-nos a consciencia da fôrça, o orgulho da nacionalidade, e, como governo, agiu com energia e desassombro em pról da emancipação do Brazil...".
} 
sobre a figura do Marechal, exaltando-o nos seus textos como defensor da nacionalidade. Esse contexto de efervescência das ideias de um jacobinismo florianista antiportuguês, com grande adesão da mocidade militar, influenciou a formação do pensamento do escritor (ALVES, 2009: 154).

Em obra publicada em 1920, A política no Brasil ou o Nacionalismo Radical, Bomílcar ${ }^{50}$ avaliava a situação de subordinação do país à antiga metrópole portuguesa. Faz ainda referência à campanha pela aproximação luso-brasileira, cujo protagonismo de João de Barros e João do Rio é conhecido, ao mencionar os esforços para se "estreitar laços de uma aliança intelectual e comercial":

“... as nações americanas, uma por uma, emancipadas de suas antigas metrópoles, trabalham hoje, cohesas, na sua vida interna, elaborando a sua grandeza e a expressão politica de sua soberania com as formulas e os moldes que melhor lhes reflectem o carácter e a independencia; ao passo que o Brazil, - onde reina a maior confusão, para consolar-se do grande mal de haver durante um século apparentado autonomia, anda agora todo preoccupado de estreitar os laços de uma aliança intellectual e commercial que o definem cada vez mais extranho a si mesmo, e cada vez mais submisso ao rêlho dos seus pretensos civilizadores" (1920: 27).

No cenário político brasileiro do período havia, segundo o líder nativista, alguns tipos de nacionalismo a combater. Eram os mesmos: o nacionalismo germanófilo, o da raça-latina e o português.

O germanófilo era fundamentado no anti-catolicismo e na Ciência do pensadores alemães. Respaldava-se, ainda, numa avaliação positiva do imigrante alemão e dos contributos da sua colónia para o Brasil. No entanto, para Bomílcar, o colono alemão só poderia ser útil quando assimilado pela cultura brasileira. Para esse efeito, fazia-se obrigatório o estudo da língua portuguesa e das coisas do país. Dever-

\footnotetext{
${ }^{50}$ No mesmo viés sociológico, publicou O Preconceito de Raça no Brasil: doutrina nacionalista (1916), pouco divulgado pela imprensa da época. Nesta primeira obra, defendeu a ideia de que a mestiçagem foi um bem coletivo ao Brasil, opondo-se a visão corrente da mesma como degeneradora da população. Segundo a leitura de Bomílcar, a mestiçagem teria produzido os vultos mais eminentes da história brasileira. E assim considerava: "O Brazileiro deve compreender que o Brazil está formando uma grande raça histórica, segundo o conceito de Litré, com elementos ethnicos americanos, africanos e europeus do norte e do sul; deve sempre lembrar-se que o progresso material e moral da pátria é obra dos esforços dos seus compatriotas e finalmente prezar e defender a amizade sincera dos povos americanos..." (BOMÍLCAR, 1920:134).
} 
se-ia lutar contra o germanófilo que desprezasse os elementos nacionais, adotando o conceito equivocado de raças inferiores ${ }^{51}$.

A adoção de tal conceito pressupunha uma visão de hierarquia racial-cultural, a qual alimentou as empresas colonialistas. Nessa perspectiva, colocava todos os brasileiros mestiços das raças tidas como inferiores (índios e africanos) numa posição de serem absorvidos pelas tidas como superiores, "em nome da Esthetica, do Progresso e da Civilização" (BOMíLCAR, 1920: 96).

O segundo tipo de nacionalismo a se impugnar era o do culto ao conceito de raça latina, "absurda ficção" aos olhos do autor. Tratava-se dos defensores da tese de serem os brasileiros; o povo, a raça e a língua latinos. Segundo Bomílcar, o nacionalismo raça-latina devia ser combatido, "porque é um culto extranho e desvirilizador, mais perigoso, mais funesto aos interesses nacionaes do que esses obscuros, innocentes ritos africanos, candonblés e pajélanças, que a policia dos suburbios persegue, em nome da ordem e da civilização!" (1920: 97). Esse falso nacionalismo disseminava uma ideia de desvalorização daquilo que era próprio da cultura brasileira e incitava à cópia dos valores tidos como superiores, tais como a moda e os costumes franceses.

Para compreendermos melhor a discussão sobre o nacionalismo raça latina proposta por Bomílcar, é interessante recuperarmos a historicidade do conceito de latinidade. Na França de Napoleão III (1852-1870), emergia o panlatinismo, doutrina que propagava a unidade dos povos de raça latina (Portugal, Espanha, Itália e França) sob liderança francesa. Nessa perspectiva, cabia à França o papel "de reconduzir, frente aos povos germânicos e anglo-saxões, as nações latinas ao lugar de principais

\footnotetext{
${ }^{51}$ Bomílcar posicionou-se, nesse sentido, contra o pensamento do escritor e diplomata brasileiro Graça Aranha (1868-1931) e dos arqueólogos Ihering (pai e filho), os quais, na sua leitura, alimentavam a ideia de hierarquização cultural. Hermann Friedrich Albrecht von Ihering (1850-1930), natural de Kiel (Alemanha), doutorou-se em paleontologia e zoologia. Emigrou para o Brasil em 1880, onde desenvolveu investigações nas áreas da zoologia, da paleontologia e da arqueologia brasileira. Naturalizou-se brasileiro em 1885. Foi nomeado diretor do Museu Paulista, cargo que ocupou durante 21 anos (1894-1915). Rodolpho Theodor Wilhelm Gaspar von Ihering (1883-1939), filho de Hermann Ihering, atuou também na área de zoologia. Exerceu função no Instituto Biológico de Defesa Agrícola e Animal de São Paulo e chefiou a Comissão Técnica de Piscicultura do Nordeste (1932-1937). In: http://www.dichistoriasaude.coc.fiocruz.br/iah/pt/index.php .
} 
protagonistas da história da civilização humana" (Feres Júnior, apud Quental, 2013: 6364).

Nesse contexto, a expressão América Latina é forjada a partir da noção de "latinidade" que fôra apropriada pelos franceses para se distinguirem da Europa anglosaxônica (Inglaterra). A esse conceito foram atribuídos diferentes significados no terreno das disputas imperialistas, segundo as ambições expansionistas de cada potência (Mignolo apud Quental, 2013: 64).

Uma outra questão importante para situarmos a ideia do nacionalismo da "raça latina" é considerarmos a reprodução de um colonialismo interno por parte das elites das ex-colónias americanas. Ao reinvindicarem a herança latina, tais elites elegiam como modelo a sociedade europeia, sobretudo a francesa. Romperam politicamente com as ex-metrópoles e afirmaram sua "americanidade" sem, no entanto, terem abandonado o desejo de serem europeus. Dessa forma, demarcaram a "sua diferença em relação aos ameríndios e aos afroamericanos, uma vez que estes, de maneira alguma, teriam como se sentir ou se perceberem europeus..." (Mignolo apud Quental, 2013: 69).

O terceiro falso nacionalismo era o português, segundo Bomílcar. Também afiliado a conceção de raça latina, este era considerado pelo escritor o "mais generalizado e pernicioso". Era o que se havia apossado do comércio (retalho e bancário), da imprensa (do Rio, de São Paulo, do Pará e do Amazonas), das empresas de navegação e cabotagem. Queria ainda impor a sua literatura e infiltrar-se "discretamente na maioria das instituições deste paiz em nome de uma camaradagem mais retumbante do que sincera" (BOMÍLCAR, 1920: 98).

Justificava-se pela herança ancestral da linguagem, disseminava o preconceito de cor entre os brasileiros e impunha o culto das "duas mães-pátrias". Dessa forma, os defensores do nacionalismo português, dentre os mesmos alguns brasileiros talentosos ${ }^{52}$, segundo Bomílcar, corroboravam para que as empresas da colónia lusa

\footnotetext{
${ }^{52}$ Cita diretamente João do Rio, Afrânio Peixoto, Medeiros e Albuquerque, Pinto da Rocha e Fausto Ferraz (1920: 100).
} 
continuassem a prosperar no Brasil, "firmando a sua discreta e silenciosa hegemonia" (1920: 98).

Contra esses nacionalismos bifrontes (ora "francelho", ora "germanófilo", ora "lusitanófilo") propunha um nacionalismo radical brasileiro voltado para as questões do país. "Fundado em honrosas tradições, na capacidade da nossa raça, na consciencia das nossas possibilidades e da nossa força, eis o que tenha aconselhado e praticado" (1920: 15-16).

Esses princípios mobilizaram Bomílcar a reunir apoiadores e a fundar revistas e organizações, as quais contribuíram para propagar essa versão de nacionalismo. Assim surgiram a Revista Braziléa e a Propaganda Nativista.

O propósito dessas intituições, segundo Bomílcar, era o estudo das questões sociais genuinamente brasileiras. Eram órgãos de resistência destinados a reunir as forças intelectuais em prol de resguardar as tradições de civismo, as conquistas e o amor à liberdade (1920: 136-137).

Braziléa foi publicada mensalmente nos anos de 1917 e 1918, dirigida por Bomílcar e Arnaldo Damasceno Vieira (1879-1951), engenheiro militar e escritor. O direcionamento do discurso nacionalista promovido pelo mensário teve como foco a luta contra a hegemonia dos portugueses em vários ramos da sociedade brasileira, assim como, a valorização da mestiçagem na construção do povo brasileiro.

Dentre os principais colaboradores da revista devemos citar o advogado e publicista Jackson de Figueiredo (1891-1928), importante referência no movimento católico leigo do período, sendo responsável pela secção bibliográfica. Figueiredo foi ainda uma influência marcante no que concerniu a aproximação dessa corrente nacionalista ao catolicismo. Outra figura de peso, a qual apresentava importante histórico nacionalista imortalizado na obra Por que me ufano do meu país (1900), foi o Conde Afonso Celso (1860-1938) ${ }^{53}$. Este divulgou um nacionalismo de cunho ufanista e criou o termo brasilidade.

\footnotetext{
53 Afonso Celso de Assis Figueiredo Junior, filho do Visconde de Ouro Preto (último presidente do Conselho de Ministros do Império). Formou-se em Direito em 1880 e foi deputado por Minas Gerais durante quatro mandatos consecutivos. Exilou-se com o pai em Portugal, após a proclamação da
} 
Segundo Lippi Oliveira, o ufanismo pode ser considerado "como a construção simbólica de maior constância e penetração no pensamento social brasileiro da Primeira República" (1990: 24). A partir dessa conceção a nacionalidade é pensada como fruto das condições naturais da terra e não como resultado dos regimes políticos. Destaca-se, portanto, a grandeza territorial, as belezas naturais, a ausência de calamidades, a variedade e amenidade climática, ao lado da valorização da três raças, consideradas fundadoras do Brasil (a portuguesa, a africana e a indígena), conferindo também destaque às qualidades do mestiço. Todas essas "superioridades" favoreciam o futuro do país, segundo as interpretações ufanistas presentes em Afonso Celso, Olavo Bilac, dentre outros.

Na perspectiva de Celso, reconhecia-se a influência dos indígenas e africanos na formação do Brasil, no entanto, subordinada a contribuição portuguesa. Predominava uma imagem de um luso-centrismo. Nesse sentido, a percepção dos indígenas e africanos assumia um papel complementar, visão essa marcada por um viés emocional e paternalista. Essa conceção perpetuou-se na abordagem da formação social e étnica do Brasil pautada na ideia de uma sociedade derivada do caldeamento das três raças: a europeia, a africana e a ameríndia (ALVES, 2009: 144).

A união entre vertentes nacionalistas que encontravam-se em campos opostos no início do regime republicano; o republicanismo e o ufanismo, dá-se pelos esforços de Álvaro Bomílcar, segundo Lippi Oliveira (1990: 24). Uma proximidade fica clara na questão da valorização da mestiçagem e, provavelmente, no reconhecimento da respeitabilidade de Afonso Celso como figura unificadora do nacionalismo. Apesar de monárquico, o conde gozou de grande prestígio intelectual e social durante a República. Celso prefaciou o livro de Bomílcar (A Política no Brasil ou o nacionalismo radical, 1920) defendendo-o da acusação de ser lusitanófobo. Definia o nativismo de Bomílcar como expressão de uma força de defesa, conservação e de progresso do país (Lippi Oliveira, idem: 133).

República. Retornou ao Brasil e dedicou-se ao jornalismo e ao magistério. Foi-lhe concedido o título de conde papal. Celso foi, ainda, um dos fundadores da Academia Brasileira de Letras e exerceu o cargo de diretor do Instituto Histórico e Geográfico Brasileiro. Segundo Lippi Oliveira, pertenceu a um grupo de intelectuais que se propôs a reabilitar o passado nacional, no início da República, ressaltando as qualidades da raça portuguesa e do catolicismo na colonização brasileira (LIPPI OLIVEIRA, 1990: 131). 
Os conceitos de raça e meio ambiente foram estruturadores das abordagens nacionalistas e antilusitanas que permearam as leituras das relações entre Brasil e Portugal nos fins do século XIX e primeiras décadas do XX. Nesse mesmo contexto interpretativo, elementos simbólicos como a história, a língua e a religião foram evocados como agentes formadores da identidade nacional brasileira. Tais elementos aparecem nos discursos que questionavam ou afirmavam o papel de Portugal e dos portugueses na constituição da identidade nacional brasileira.

O programa da revista Braziléa, lançado no primeiro número, anunciava que o propósito do periódico era o de preencher uma lacuna na imprensa do país. Tratava-se de um meio de divulgação das coisas brasileiras, visto que:

"Quasi todos os nossos periodicos, - diarios e 'magazines' - tem a sua esphera de actividade adstricta ao senso esthetico. E como, nesse particular a coisas européas, inglezas, francezas ou lusitanas, - são as que mais seduzem e interessam ao publico ledor, os nossos apreciados collegas, ao envez de gastarem sua tinta e seu tempo occupando-se das seáras indigenas, e tornando recommendaveias as bellezas magestosas do paiz, - bellezas que se encontram veladas na modestia da alma brazileira e existem esquecidas nas paginas dos compendios didacticos, - vão logo, directamente, ao alvo preferido, fornecendo ao paladar intellectual o acepipe que mais facilmente poderá agradar á maioria" (Redação, 1917: 3).

A Propaganda Nativista criada em 21 de Abril (Dia de Tiradentes ${ }^{54}$ ) de 1919, na Rua do Carmo no Rio de Janeiro, teve suas ideias embrionárias cultivadas na Revista Brazilea (1917-1918) $)^{55}$. No entanto, a principal fonte divulgadora do seus princípios norteadores foi a Revista Gil Blas (1919-1923), sob a direção do advogado e escritor Alcebíades Delamare (1888-1951).

O patrono da entidade era Floriano Peixoto, figura ícone do nacionalismo radical ao qual se identificava a associação. Apresentou-se como um movimento

\footnotetext{
${ }^{54}$ Joaquim José da Silva Xavier (1746-1792), o Tiradentes, é reconhecido como mártir da Inconfidência Mineira. Foi recuperado como figura heróica pela República e seus ideólogos positivistas. 0 dia da sua execução, 21 de Abril, é feriado nacional.

${ }^{55}$ Houve uma segunda fase da revista, relançada em 1931. Nesse período participaram vários autores que se destacam no movimento integralista brasileiro, tais como; Raimundo Padilha, Ovídio da Cunha e o próprio Plínio Salgado. Álvaro Bomilcar também colaborou nessa fase, no entanto, as seus textos apresentavam conteúdo similar ao dos artigos publicados na primeira edição da revista (LIPPI OLIVEIRA, 1990: 150).
} 
político, o qual "deverá subsistir pelo devotamento e espirito de sacrificio de seus membros, que serão brazileiros natos" (BOMíLCAR, 1920: 179).

A entidade visava, sobretudo, trabalhar pela emancipação económica, intelectual e financeira do Brasil, libertando-o da submissão aos interesses estrangeiros, com base na defesa das ideias republicanas e democráticas. Pretendia, dentre outras questões, cultivar a solidariedade entre as nações americanas e combater a influência das modernas nações europeias, defender o mercado de trabalho para os brasileiros evocando medidas para regulamentar a imigração, a qual deveria ser encaminhada somente aos serviços da lavoura (BOMíLCAR, idem: 179180).

Constituía-se ainda dentre os objetivos da associação criar ramificações pelos diferentes Estados brasileiros. Cabe referir que, ao lado de Álvaro Bomílcar ${ }^{56}$, Jackson de Figueiredo e Delamare desempenharam papéis relevantes na defesa dessa vertente nacionalista. Posteriormente, o viés lusófobo assumido num primeiro momento foi aplacado em função da adesão desses dois personagens ao movimento católico.

A Ação Social Nacionalista (ASN) foi fundada em 1920, no Instituto Histórico e Geográfico do Rio de Janeiro, sob a influência da Propaganda Nativista. A associação foi idealizada por Delamare, responsável pela redação dos seus objetivos concentrados em propor uma grande campanha de nacionalização do país. No entanto, este não ocupou cargos na direção da entidade, os quais foram destinados a políticos e intelectuais influentes. Tinha como presidente Afonso Celso ${ }^{57}$ e na presidência de honra figurava Epitácio Pessoa (1865-1942), então no Governo do país. Como vicepresidentes foram indicados: Álvaro Bomílcar, o então deputado Camillo Prates, o senador Justo Chermonts e o dr. Raul Guedes.

Segundo Nóbrega de Jesus, é provável que a escolha de nomes importantes do cenário político e intelectual da época para estarem a frente da Ação visassem conferir ao movimento maior credibilidade e legitimidade (2013: 121). Abriu-se ainda uma

\footnotetext{
56 Mesmo em Bomílcar notou-se um respeito ao catolicismo. A Igreja Católica, nas suas palavras; "sempre visou a ordem, o bem e a união espiritual do Mundo". Ressaltava, ainda, o contributo dos Jesuítas na formação do Brasil (1920: 39).

${ }^{57}$ Nessa altura, Afonso Celso ocupava os prestigiosos cargos de diretor da Faculdade Nacional de Direito e de presidente do Instituto Histórico e Geográfico Brasileiro.
} 
secção na Revista Gil Blas com o propósito de divulgar o programa e eventos promovidos pela entidade.

Apesar das afinidades com a Propaganda, cabe chamar atenção às diferenças entre os dois movimentos, conforme analisou Lippi Oliveira. A Propaganda Nativista definiu-se como uma sociedade de carácter político, enquanto a Ação Social apresentou-se como uma instituição defensora dos estudos sociais e históricos, sem cunho político ou religioso. Apesar das declarações em ambos os programas, a ASN comprometeu-se com momento político da época ao associar-se aos Governos de Epitácio Pessoa (1919-1922) e Artur Bernardes (1922-1926) enquanto a Propaganda defendia de uma forma mais ampla as ideias republicanas. Outra posição assumida pela Ação Social foi um compromisso com o catolicismo. Os dois movimentos propunham-se a combater o analfabetismo, no entanto, a Ação desejava incluir nesta campanha o ensino religioso nas escolas públicas (1990: 155-156).

Feitas essas considerações, podemos nos voltar para alguns temas presentes na Revista Gil Blas, os quais nos auxiliam a dialogar com as questões propostas por João de Barros em O Sentido do Atlântico, assim como situar algumas impressões acerca da estadia do poeta no Brasil de 1920. Uma ideia acerca do perfil do semanário pode ser esboçada a partir da seguinte citação:

“' 'Gil Blas' - único orgão nacionalista da imprensa carioca, que tem com todo desassombro e coragem, mettido o ferro em braza de sua critica altiva na chaga purulenta do lusitanismo audaz e cupido, que vem desde 1500, tentando desvirilizar e desfibrar a nossa nacionalidade, o que não conseguiu ainda, graças ás energias de outras raças, caldeadas no sangue do nosso povo... " (25/9/1919, № 33: 10).

É bastante clara a mensagem xenófoba e, sobretudo, lusófoba propagada pela revista. Vale ainda ressaltar, que uma das características constantes ao longo da sua publicação foi a edição em formato de panfleto, conforme enunciado no subtítulo ${ }^{58}$. É importante referir que o jornalismo panfletário brasileiro emergiu na trajetória dos

\footnotetext{
${ }^{58}$ Gil Blas: Panfhleto de Combate até o no 20 (1919). A partir do no 21 (3/7/1919) ocorreram algumas mudanças na orientação do periódico, dentre as quais no subtítulo, alterando-se para Panfheto Semanal. No número $34(3 / 10 / 1919)$ registou-se nova mudança no subtítulo que passava a Panfhleto Nacionalista. No entanto, a última alteração fez-se notar no no 188 (20/10/1922): Panfhleto Nacionalista: pela brazilidade e pelo catolicismo (NÓBREGA DE JESUS, 2013:36-38).
} 
movimentos republicanos e abolicionistas, entre os finais do XIX e início do XX. Esse tipo de periódico era geralmente controlado por uma pessoa ou um grupo, cujo objetivo era defender e divulgar os seus posicionamentos políticos e ideológicos (JESUS, 2013:40).

Apesar das oscilações constantes no percurso do semanário (proprietários, localização da redação, número de páginas, espaço destinado a publicidade, organização dos artigos e secções, etc.), Alcebíades Delamare manteve-se como diretor responsável e redator-chefe ao longo dos $200^{59}$ números publicados. Segundo o diretor:

“... é dever precipuo de todo o bom brasileiro entregar-se, de corpo e alma, a essa campanha nacionalista que estúa de todos os recantos do país, exigindo, em nome da nossa honra, a nossa completa emancipação... Quem se der ao trabalho de examinar imparcialmente o que se está passando no Brasil, principalmente na cidade do Rio de Janeiro, para logo se convencerá de que vivemos desgraçadamente sob o jugo nefasto do extrangeiro, em especial do português, que se julga, aliás, perfeitamente a vontade para arrogar-se o direito, que Ihe não assiste, de critica, de desfazer e de deprimir, da maneira a mais revoltante e a mais odiosa, os homens e as cousas da nossa Patria" (A Questão Nacionalista in Gil Blas, 16/10/1919, № 36: 3).

Para entendermos melhor as ideias de Delamare, é importante acrescentarmos que na sua visão o nacionalismo significava Deus e Pátria. "O primeiro é a força irresistível que nos atrai para a perfectibilidade do nosso espírito; o segundo é o imã que nos prende ao solo em que nascemos" (DELAMARE apud Lipp Oliveira, 1990: 153). O autor assumia-se como simpatizante do Governo de Mussolini, identificando-o como figura que reerguia a "italianidade" ao promover a união do civismo e da religião. $\mathrm{Na}$ sua perspectiva, sem catolicismo não poderia haver nacionalismo.

O panfleto nacionalista e seus colaboradores parecem ter acompanhado com certa assiduidade a estadia de João de Barros nas cidades do Rio de Janeiro e de São Paulo, durante os meses de Abril e Maio de 1920. Sendo assim, dois artigos remetendo-se ao poeta foram publicados no no 68 de Gil Blas.

\footnotetext{
${ }^{59}$ Primeiro número lançado em 13 de Fevereiro de 1919 e último em 6 de Maio de 1923.
} 
O primeiro foi escrito pelo polémico ensaísta e jornalista Antônio Torres (18851934), intitulado "União Luso-brazileira", com subtítulo; ao Dr. João de Barros, conforme recorte a seguir:

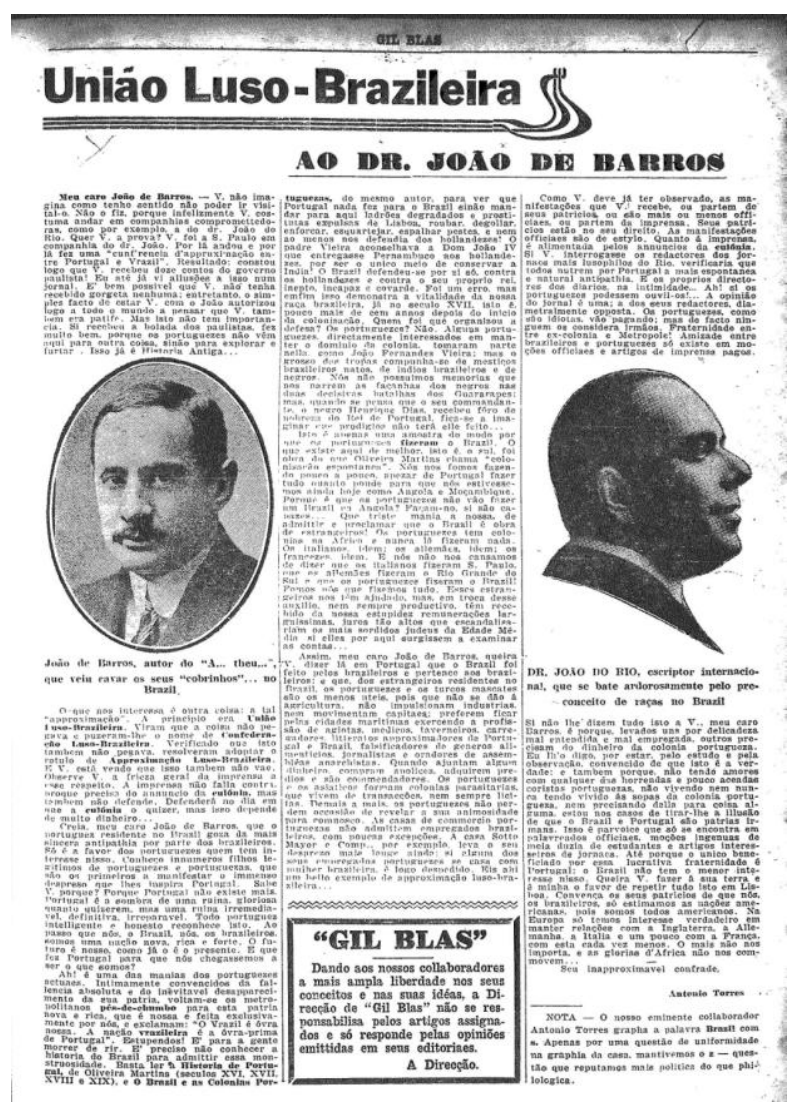

Antônio Torres, “União Luso-Brazileira”, Gil Blas, 27/5/1920, № 68, p. 3

Nota-se que trazia fotos dos dois paladinos da aproximação luso-brasileira, com legendas pouco lisonjeiras: “João de Barros autor do 'A... theu...' que veiu cavar os seus 'cobrinhos' no Brazil" e "Dr. João do Rio, escriptor internacional, que se bate ardorosamente pelo preconceito de raças no Brazil".

Torres quis deixar as suas impressões bastante claras ao visitante, utilizando-se de comentários irónicos e marcados pelo escárnio. Fazia galhofa, por exemplo, com sotaque português. Nesse registo, afirmava ter lastimado não ter ido visitar João de Barros, devido ao facto do mesmo andar acompanhado de pessoas comprometedoras, como João do Rio. Dizia ainda que, pelo tipo de companhia, circulava a notícia de que o poeta havia recebido doze contos do Governo paulista pela "cunf'erência d'appruximação entre Portugal e Vrazil". Colocava isto em dúvida, no entanto 
acrescentava; "Si recebeu a bolada dos paulistas, fez muito bem, porque os portuguezes não vem aqui para outra coisa, sinão explorar e furtar. Isso já é Historia Antiga..." (Gil Blas, 27/5/1920, № 68: 3).

Após tecer considerações acerca da relação histórica entre Brasil e Portugal, respaldou-se nas obras de Oliveira Martins ${ }^{60}$ para afirmar que Portugal nada fez pelo Brasil, "sinão mandar para aqui ladrões degradados e prostitutas expulsas de Lisboa, roubar, degollar, enforcar, esquartejar, espalhar pestes, e nem ao menos nos defendia dos hollandezes!..." (idem). Em tom de conclusão arrematou com a seu recado virulento e xenófobo:

“Assim, meu caro João de Barros, queira V. dizer lá em Portugal que o Brazil foi feito pelos brazileiros e pertence aos brazileiros: e que dos estrangeiros residentes no Brazil, os portuguezes e os turcos mascates são os menos úteis porque não se dão á agricultura, não impulsionam industrias, nem movimentam capitaes; preferem ficar pelas cidades maritimas exercendo a profissão de agiotas, medicos, taverneiros, carregadores, litteratos aproximadores de Portugal e do Brazil, falsificadores de generos alimenticios, jornalistas e oradores de assembleas anarchistas ${ }^{61}$..." (ibidem).

Faz-se necessário uma ressalva, ao fim da página a direção do Gil Blas publicou uma nota na qual dizia não se responsabilizar pelos artigos assinados, respondendo somente as opiniões expressas nos editoriais. Essa era uma forma de se resguardar, no caso dos discursos mais agressivos ou que divergissem politicamente da diretriz do periódico.

\footnotetext{
${ }^{60}$ História de Portugal (1879) e O Brasil e as Colónias Portuguesas (1880). Oliveira Martins fez parte da geração de 1870, juntamente com Eça de Queiroz, Antero de Quental, dentre outros, que buscou uma renovação da vida política e cultural portuguesa da época. Tratavam-se de intelectuais bastante críticos da estrutura social e política do país, cujo pensamento influenciou as gerações posteriores. Não seria difícil, segundo uma agenda pré-definida, selecionar argumentos a partir dessas obras que pudessem alimentar um discurso lusófobo e que imprimisse uma visão negativa acerca da colonização portuguesa. Sobre a geração de 1870 conferir: MACHADO, Álvaro Manuel. A Geração de 70 - uma revolução cultural e literária. Lisboa: Instituto de Cultura e Língua Portuguesa, 1986.

${ }^{61}$ Nesse período, a doutrina anarquista difundia-se na sociedade brasileira em meio aos surtos das greves operárias As imagens dos portugueses como exploradores foram, em geral, associadas ao movimento anarquista, sendo identificados como responsáveis pela desordem social e económica. Contrariamente, à imagem construída pela elite da colónia portuguesa do Rio de Janeiro em torno do imigrante português como obediente, trabalhador e apolítico, conforme referido na primeira parte desse trabalho.
} 
Nascido em 1885, Diamantina (Minas Gerais), Torres frequentou o seminário ordenando-se padre em 1908, no entanto sem vocação. Rompeu com a Igreja e iniciou no Rio de Janeiro carreira jornalística, atuando em periódicos diversos, tais como: $A$ Notícia, Brazilea, Correio da Manhã, Gazeta de Notícias, Gil Blas e O Paiz. Teve ainda incursão na carreira diplomática, nomeado Cônsul do Brasil em Londres (1920-1923) e depois em Hamburgo (1926), onde veio a falecer (1934) em exercício do cargo.

Antônio Torres era conhecido pela sua militância contra a colónia portuguesa e a mensagem lusófoba propagada. Os seus escritos destacavam-se pela virulência em relação a permanência da influência lusitana e contra os defensores da aproximação luso-brasileira (Afrânio Peixoto, João do Rio, Medeiros e Albuquerque, Malheiro Dias, João de Barros, Filinto de Almeida, etc.). Escreveu, por exemplo, pesadas críticas à João do Rio, devido ao comportamento combativo do mesmo em defesa do imigrante e legado português no Brasil, assim como, em função do prestígio que este gozava junto à colónia e à intelectualidade lusa.

No livro As Razões da Inconfidência (1925) ${ }^{62}$, Torres destilou todo o seu antiportuguesimo ${ }^{63}$. Essa obra divide-se em duas partes. A primeira apresenta um extenso preâmbulo onde são referidos vários factos e características dos portugueses, destacando-se a luxúria ("pansexualismo") e a cobiça. Acerca da exacerbação sexual que imputa ao caráter português, lançou, dentre outras, a seguinte pérola: “... Os intellectuaes portuguezes, quando viajam pelo Brasil, só olham para pernas, braços, seios, caras, ancas e nalgas de mulheres! Que será isso? Loucura? Priapismo racial? Não sei o que será, mas não pode ser coisa bôa. Deve ser doença" (TORRES, 1925: $\mathrm{XCVI})$.

O autor reforça a ideia de que todos os problemas brasileiros tiveram como origem a colonização portuguesa. Nessa parte, o discurso é abertamente antilusitano,

\footnotetext{
62 Essa obra teve origem numa conferência realizada em 21 de abril de 1924, na qual o jornalista Antônio Torres prestou homenagem a Tiradentes no Centro Mineiro do Rio de Janeiro. A pequena conferência foi editada um ano depois com o título As razões da Inconfidência, a qual acrescentou-se um preâmbulo de mais de 100 páginas e extensas notas.

63 "Esta é a grande raça que se gaba de ter feito o Brasil de hoje - risum teneatis! - e que ainda por aqui vive sanguesugando a nossa patria commodamente, a sombra do nosso liberalismo criminoso! Rustica e retardada, no conceito de seus proprios escritoptores e poetas mais altos. Analphabeta segundo as estatísticas. Patranheira, sensual e trapaceira, conforme nol-o ensina a experiencia que della temos. Hurrah! Hurrah! Pela grande raça civilisadora!..." (TORRES, 1925: LV).
} 
deixando-se de lado qualquer pretensão ensaística e assumindo contornos de mera piada de português (BUENO, jan./jun. 2003: 95). Observe-se, como exemplo, a seguinte passagem sobre o mito da construção do Brasil pelos portugueses, com referência a João de Barros:

“... É a velha mania dos portuguezes: o Brasil - que nós apenas começamos, e com grandes difficuldades, a ir construindo - é obra e propriedade delles... João de Barros, litterato portuguez de 2a classe, faz uma conferencia luso-brasileira e, intitula-a: Portugal maior ${ }^{64}$ ! Alberto d'Oliveira, outro litterato portuguez de egual classe, escreve um livro rachitico a respeito do Brasil e intitula-o: Da outra banda de Portugal! ${ }^{65} \mathrm{O}$ Brasil, immenso em territorio e em possibilidades, com 32 milhões de habitantes, fica sendo apenas uma projecção de Portugal, paizote de quatro milhões de cabeças, arruinado, encalacrado e desmoralisado a ponto de já ter dado até um neologismo á lingua franceza: o verbo portugaliser!" (TORRES, 1925: LXXXII-LXXXIII).

A segunda parte traz a conferência que aborda o período da Inconfidência Mineira inserido no contexto das Minas colonial do século XVIII, mantendo-se o espírito antilusitano, mas com algum embasamento histórico. Dessa forma, Torres pinta com cores fortes a repressora legislação que regulou a região das Minas no século XVIII, com vistas a acentuar a vileza do caráter português. Segundo Jorge Luís Alves, na leitura de Torres prevalecia a imagem da vitimização da então colónia pela metrópole, pautada pelo binómio vítima/algoz e no uso de figuras próprias do discurso religioso, tais como: holocausto, martírio, etc. (2009: 170).

Torres utilizou como fonte primária as ordens régias circunscritas a época e respaldou-se novamente na análise crítica de Oliveira Martins, com intuito de ressaltar as falhas na administração portuguesa. Ao buscar os fundamentos da legislação repressora, “... no fundo as tais razões da Inconfidência - Antônio Torres encontra o traço do caráter português que mais o interessará: a cobiça. Era preciso extrair o ouro

\footnotetext{
${ }^{64}$ Conferência proferida à colónia portuguesa do Rio de Janeiro por João de Barros em 1920. Foi editada no mesmo ano e será analisada mais adiante.

${ }^{65}$ Conjunto de textos e conferências reunidos pelo ex-Cônsul Geral de Portugal no Brasil na obra $\mathrm{Na}$ Outra banda de Portugal: quatro anos no Rio de Janeiro (1919). Algumas ideias presentes nesse livro serão mencionadas mais à frente.
} 
- daí a proibição a todas as atividades que não fossem a mineração..." (BUENO, jan./jun. 2003:98).

Uma última observação acerca de As Razões da Inconfidência é a receção conferida a obra, sugerindo mais pistas de um certo adesismo à mensagem lusófoba propagada. A primeira edição, de três mil exemplares, esgotou-se em apenas 15 dias. A segunda tiragem também não se demorou a expirar e, desta feita, teve lugar a uma terceira edição (BUENO, idem: 93).

Deve-se ainda acrescentar que foram publicadas respostas à obra, rebatendose todas as provocações e mantendo-se no fundo o mesmo viés preconceituoso evocado por Torres ${ }^{66}$. Registaram-se também críticas positivas, tais como a de Agripino Grieco (1888-1973), que afirmava tratar-se de uma obra de paixão patriótica e denúncia corajosa da realidade do país (ALVES, 2009: 166). As ideias expressas em As Razões da Inconfidência ia ao encontro do sentimento de incómodo partilhado por setores da intelectualidade brasileira em torno do discurso de uma aproximação lusobrasileira no período. Nesse sentido, as iniciativas movidas com o intuito de apoiar esse discurso eram recebidas como um conjunto de intromissões indevidas.

Gastão Cruls relativizou a repugnância de Torres ao imigrante lusitano, ao afirmar que as simpatias do jornalista encontravam-se voltadas para a gente mais simples. Sendo assim, manteve relações amistosas com o editor de seus livros, o português António Castilho, e com os donos da pensão, onde viveu por vários anos no Catete (apud ALVES, idem: 170). Nessa questão, Jorge Alves considera a visão de Torres próximo a de Álvaro Bomílcar. Os dois escritores aceitavam o imigrante luso "como indivíduo potencialmente assimilável ao nacional, mas o combatiam como grupo - a colônia - organizado na defesa de interesses específicos nos quais viam, muitas vezes, objetivos contrários ao Brasil e aos brasileiros" (ibidem: 170).

O outro artigo da revista Gil Blas que tratou da estadia de João de Barros no Brasil foi enviado pelo escritor Carlos Maúl (1887-1974). Nascido em Petrópolis, descendia de colonos alemães. Mudou-se para o Rio de Janeiro com a finalidade de

\footnotetext{
${ }^{66}$ Conferir: CASTRO, Vitório de. Brasileiros e portugueses. Rio de Janeiro: Teixeira \& Cia.,1925; ROMANO, Raul. Veneno! Resposta às Razões da Inconfidência. São Paulo: Livraria Zenith, 1925.
} 
completar os estudos e firmou-se como jornalista, escritor e poeta, elogiado e respeitado no meio literário. Foi membro da Sociedade Brasileira de Geografia e de Filosofia, Secretário Geral do Conselho Supremo da Ação Social Nacionalista e redator dos jornais Correio da Manhã, A Imprensa, Gazeta de Notícias, dentre outros. Ao longo da sua carreira publicou cerca de 60 livros dedicados à poesia, teatro, traduções, história e crítica literária. Algumas dessas obras foram editadas em Portugal.

Maúl abordou as questões defendidas por Barros em prol da aproximação lusobrasileira e demonstrou conhecimento acerca da produção do autor sobre a matéria. Em tom mais argumentativo e menos ofensivo, o escritor recorreu ao título " $\mathrm{A}$ confusão luso-brazileira", o que sugere, no mínimo, questionamentos acerca dos discursos lusobrasileiristas.

Maúl inicia o texto dizendo que se fazia necessário contraditar as propostas de João de Barros, pois os discursos deixavam de ser apresentados com ares de comicidade, aos gritos de "Pelo Brazil, por Portugal" e passavam a clamar por medidas oficiais:

“... O que nos move a uma apreciação da campanha que elles [referindo-se também a João do Rio] sustentam é o enthusiasmo com que o dr. João de Barros deseja que a 'approximação entre os dois paizes tome uma fórmula legal, definitiva e definida; expressando-se em tratados, em reciprocidade de relações entre governos, em permanente e effectivo contacto intellectual artistico e economico entre as duas nações'" (Gil Blas, 27/5/1920, № 68: 6).

Para fundamentar tais observações, o escritor brasileiro identificava alguns dos argumentos salientados por João de Barros em conferência proferida no então Ateneu Comercial do Porto, logo depois publicada e intitulada: A Aproximação Luso-brasileira e a Paz (1919).

Tendo em vista os debates e o rescaldo político-económico do pós I Guerra, afirmava Barros nessa conferência, ao citar Malheiro Dias (1875-1941) ${ }^{67}$, que o Brasil era alvo de intensa corte por parte dos países aliados. Constituía-se numa terra de

\footnotetext{
${ }^{67}$ Filho de pai português e mãe brasileira, Malheiro Dias foi romancista, jornalista, historiador, político e grande defensor da causa luso-brasileira. Adepto da Monarquia e do Integralismo, exilou-se voluntariamente no Brasil após a Proclamação da República Portuguesa (1910), entre os anos de 1913 a 1935. Tornou-se conhecedor dos problemas que envolviam a colónia portuguesa no Rio de Janeiro e buscou apontar soluções para a melhoria do relacionamento entre imigrantes portugueses e brasileiros.
} 
promissão, com "vasto campo de exploração agrícola, de exploração industrial e comercial, insuficientemente povoado, prodigiosamente rico de tôda sorte de matérias primas...", tornando-se assim destino escolhido por diferentes correntes imigratórias (A Aproximação Luso-brasileira e a paz, 1919: 16). Havia, portanto, necessidade de se fortalecer os laços entre Portugal e a "terra irmã", sobretudo nesse contexto de disputa de influências. Fazia-se necessário maior esclarecimento e comprometimento das autoridades portuguesas para com essa questão, tendo em vista as perdas significativas causadas pelo afrouxamento dessas relações, enumerando-se:

"1. Os cinco ou seis mil contos enviados pelos nossos emigrantes todos os anos...; 2. Uma grande parte da nossa vida comercial e industrial; 3. Mais da metade, seguramente, do nosso mercado literário e artístico; 4. A certeza dum acolhimento favorável a nossa tradicional febre de aventura e ambição; 5. A garantia de que a literatura, a arte e o pensamento de Portugal encontram a possibilidade de uma expansão que só um dia poderão encontrar na nossa colónia de Angola (!Em Lourenço Marques não há uma única livraria portuguesa, posso afirmá-lo!)..." (BARROS, idem: 19).

Digamos que o conhecimento dessas afirmações de João de Barros podia ser assimilado para se reafirmar algumas das leituras nacionalistas antiportuguesas da época e utilizado para se questionar as intenções da campanha movida pelo poeta. Tais pontos enunciados por Barros, como perdas para Portugal, foram reproduzidos no artigo de Maúl e criticamente avaliados.

Aos olhos de Maúl, era a política económica o motivo de toda a literatura de Barros em contraposição a consolidação de uma autonomia mental e comercial brasileira. E assim continuava a sua explanação afirmando que os portugueses gozavam de larga vantagem no Brasil, mas pelos vistos queriam mais: “... Pois já não está nas mãos dos lusos quasi todo o commercio de livros?... Não têm elles a 'nossa' imprensa política?... Contra cada livro nacional que apparece não nos atiram elles dez ou vinte, que apezar de inferiores, têm mais vendas graças á protecção das nossas alfandegas?..." (Gil Blas, 27/5/1920, № 68: 6).

Destacava ainda a preocupação de João de Barros com a superação dos imigrantes portugueses pelas outras colónias. Nessa altura, os italianos já começavam a se impor numericamente. No entanto, o imigrante português era o único, segundo 
Barros, que representava um elemento nacionalizador, pois falava a mesma língua, tinha os mesmos costumes e adaptava-se com facilidade ao meio. Enfim, havia um encontro nas sensibilidades dos dois povos (1919: 22).

Esse argumento do escritor português encontrava-se em sintonia com algumas das preocupações da época em torno da ameaça da cultura nacional, sobretudo pelas características atribuídas a imigração alemã e italiana. Nesse caso, prevalecia a leitura de que a matriz formadora da cultura brasileira era portuguesa, grandemente respaldada pela manutenção e apropriação da língua portuguesa pelos brasileiros. Dentre os intelectuais brasileiros, Sílvio Romero em conferência de $1902^{68}$ esboçou tal preocupação em função do estabelecimento de núcleos alemães no Sul do país, os quais procuravam manter a sua cultura e até buscavam impor o ensino da língua alemã nos municípios em que viviam.

Carlos Maúl opunha-se a essa visão ao afirmar que os brasileiros não temiam a influência dos povos americanos, alemães, franceses ou italianos. Esses conviviam na sociedade brasileira sem preoccupação de identidade de língua e de tradições. Ofereciam vantagens em relação ao intercâmbio comercial, pois importavam mais do que exportavam ao Brasil. Não possuíam Afrânios Peixotos a serviço nas escolas. Daí advinha a conclusão de que não eram esses imigrantes que poderiam vencer os portugueses, pois "quem quer vencer os portuguezes aqui somos nós, exclusivamente nós" (Gil Blas, 27/5/1920, № 68: 6).

Quanto a referência ao ensaísta, médico e político Afrânio Peixoto (1876-1947) devia-se a facto de Barros ter citado o seu livro Minha Terra e Minha gente (1915), utilizado como manual nas escolas públicas do então Distrito Federal e também em outros Estados. Segundo o poeta português, essa obra contribuía para a formação moral do cidadão brasileiro e reafirmava a importância da tradição lusitana na cultura brasileira. Documentava "que o passado heróico da nacionalidade portuguesa é património comum das duas Pátrias" (1919: 24).

Apenas para termos uma breve referência da interpretação acerca da colonização portuguesa e do seu contributo na formação do Brasil presente em Minha

\footnotetext{
68 "A conveniência de fortalecer no Brasil o elemento português", título da conferência realizada no Real Gabinete Português de Leitura do Rio de Janeiro, em 1902.
} 
Terra, Minha gente, observemos a conclusão do III capítulo dedicado às navegações lusas: "Descobriram o Brasil, que seria a maior glória portuguêsa, herdeiro de seu sangue, tradições, lingua, costumes, que no futuro iria e, ha de ir ainda, continuando a fama lusitana..." (1916: 46)

Estamos a insistir nesse ponto da instrução cívica escolar, pois revelou-se como um dos pontos fortes do argumentário de João de Barros. Devido aos seus estudos, projetos e conceções em torno da importância do ensino na formação de cidadãos demonstrou interesse pelo tema da diretriz educacional nas escolas brasileiras desde a primeira visita ao Rio de Janeiro e São Paulo, conforme vimos anteriormente. Aos olhos do poeta, o uso desse tipo de manual que exaltava a História Portuguesa constituía-se como primordial na manutenção da coesão cultural luso-brasileira e indicava também o reconhecimento dos laços entre os dois países por parte da sociedade brasileira.

Ao escrever O Sentido do Atlântico, João de Barros pretendia demarcar a sua visão em torno do nativismo brasileiro e dos ecos dessas ações em Portugal. Buscou matizar tais movimentos afirmando não haver no Brasil ódio aos portugueses, mas sim inimigos de Portugal. Tratavam-se, portanto, de episódios isolados, mais ou menos violentos "a sua acção exerce-se com maior ou menor éxito: - assim, enquanto eu estive no Brasil, em Abril e Maio do ano passado, não senti os seus efeitos..." (1921: 64-65).

O jornalista, crítico, filólogo, historiador, pintor, professor brasileiro João Ribeiro (1860-1934), outro intelectual de destaque no cenário da época, encaminhou um artigo ao Gil Blas para dar a sua opinião acerca da política literária de aproximação luso-brasileira. O mesmo intitulado "Jacobinismo portuguez" foi publicado em Outubro de 1920, portanto, alguns meses após a estadia de João de Barros em terras brasileiras.

As questões apresentadas por Ribeiro merecem a nossa atenção, do ponto de vista dos diálogos estabelecidos no período em torno dos laços culturais entre os dois países. O autor considerava despropositado um programa de intensificação das relações entre Portugal e Brasil, visto que as mesma nunca deixaram de existir. No entanto, havia sim um decrescimento da influência intelectual lusa no Brasil; "já não precisamos, como outrora, de uma palavra de recommendação de Herculano ou de 
Castilho. Os tempos são outros" (Gil Blas, 7/10/1920, № 87, p. 4). Ribeiro evoca nessa passagem o percurso de afirmação da autonomia da literatura brasileira no próprio país e dentro de uma literatura americana.

Afirmava ainda não haver reciprocidade no mercado comercial entre as literaturas portuguesa e brasileira. Os intelectuais lusos eram lidos e contribuíam com seus escritos nos jornais brasileiros, coisa que não ocorria do outro lado do Atlântico.

Vale ressaltar, que este ponto foi abordado por João de Barros in $A$ Aproximação Luso-brasileira e a Paz, o poeta reconhecia essa desigualdade e clamava por iniciativas que pudessem solucionar tal disparidade, enquanto não se consolidassem medidas oficiais: “... porque não hão-de os editores portugueses ajudar um pouco- e ter á venda livros de escritores brasileiros, difíceis de encontrar nas nossas livrarias?... Porque não hão-de os directores dos jornais portugueses pedir- e pagar- colaboração brasileira?" (1919: 31).

Para Ribeiro, a escassez de livros brasileiros em Portugal, para além da questão comercial, poderia ser compreendida pela falta de identificação intelectual. Os portugueses da Europa, segundo o autor, não compreendiam a literatura americana, achavam-na "bastarda, imperfeita, differenciada, languida ou disforme, em qualquer caso sem maior interesse que o de uma amostra dialectal” (Gil Blas, 7/10/1920, № 87, p. 4).

Esta incompreensão da literatura americana e, no caso, da brasileira traduzia-se numa espécie de hierarquização cultural na visão de Ribeiro. Por parte dos propagandistas da aproximação cultural luso-brasileira e como exemplos contemporâneos citava João de Barros e Alberto de Oliveira (1873-1940) havia uma atitude natural e inconsciente em suprimir o Brasil tomando-o como uma cultura subentendida à portuguesa. Citava, como exemplo nesse sentido, os títulos conferidos a uma conferência e livro, realizados por Barros e Oliveira, respectivamente: Portugal Maior (1920) e Na outra banda de Portugal: quatro anos no Rio de Janeiro (1919) ${ }^{69}$. Denominava a esse tipo de atitude mental como jacobinismo português, mais excessivo que o tão falado jacobinismo brasileiro.

\footnotetext{
${ }^{69}$ As mesmas obras foram mencionadas no artigo de Antônio Torres.
} 
João Ribeiro defendia a autonomia literária em relação a Portugal e adotou postura crítica em episódisos que sugeriam uma superioridade cultural dos letrados portugueses em relação aos brasileiros. Em suas obras posicionou-se contra o purismo gramatical e o perfil excessivamente lusófilo, no caso da língua, da intelectualidade brasileira das primeiras décadas do século XX (ALVES, 2009: 184).

João de Barros em $O$ Sentido do Atlântico manifestou ideia próxima a de João Ribeiro ao falar de um nativismo português que impedia a compreensão da alma brasileira "fazendo com que, do Brasil, nós conservemos ainda aquele antigo preconceito de que lá não se encontra nem cultura, nem progresso, nem civilisação" (1921: 70). Ainda questionava o autor se este nativismo português seria menos contundente do que o nativismo do Gil Blas e o do comandante Vilar ${ }^{70}$. Ao qual concluía: “De facto. Mas quasi igualmente ofensivo, e formidavelmente prejudicial para nós ... É um vexame. É, sobretudo uma ausencia completa de espirito patriotico" (BARROS, 1921: 70).

O livro de Alberto de Oliveira, antigo Cônsul Geral de Portugal no Brasil (19151918), sócio da Academia de Ciências de Lisboa e da Academia Brasileira de Letras, foi dedicado à colónia portuguesa do Brasil, em especial aos seus representantes do Rio de Janeiro. Apresentava um conjunto de conferências e escritos, pelos quais o autor buscava definir a sua atuação no cargo diplomático e o seu pensamento sobre as relações luso-brasileiras.

O título passava uma imagem do Brasil como extensão de Portugal na outra banda do Atlântico. Nas palavras do autor: “... dois Portugaes separados por um mar ainda tão nosso..."(1919: 285). Afirmava ainda Oliveira, ter sido o Brasil a única colónia, da qual Portugal conseguiu fazer uma nação. No entanto, ainda havia a necessidade dos portugueses ajudarem a consolidar a formação do país. Na sua visão, essa tarefa estava sendo desempenhada pelos imigrantes portugueses. "É nesse sentido que eu digo que o Brasil, politicamente emancipado e independente, nem por isso deixou de ser o nosso filho, nem por isso deixou de ser nosso" (A. De OLIVEIRA, 1919: 283-284).

\footnotetext{
70 Comandante Frederico Villar, nomeado pelo Ministro da Marinha de Guerra brasileira como responsável pela aplicação da lei de nacionalização da pesca e da costa brasileira (1919-1923). Essa medida nacionalizando desencadeou grande polémica, conforme veremos adiante.
} 
Digamos que esta obra do escritor português forneceu munição para a ira dos nativistas brasileiros, sobretudo ao alimentar a imagem de "paternidade" e "filho" ainda dependente, de alguma forma. Nesse sentido, advinha, dentre outras críticas, a questão identificada por João Ribeiro de não reconhecimento da autonomia cultural brasileira.

A conferência de João de Barros mencionada por Ribeiro, isto é, "Portugal Maior" ${ }^{\prime 11}$ foi destinada à colónia portuguesa do Rio de Janeiro ; com dedicatória "aos portugueses do Brasil". Houve calorosa saudação de João do Rio que introduziu a importância do contributo literário de Barros e concluiu com a seguinte declaração: “Deixai-me dizer que todos nós vos amamos por isso - os portuguezes por que sois a fé alegre, a juventude alegre, a energia certa na grandeza maior de Portugal; os brazileiros porque, mestre de acção, amais no Brazil o esforço dos brazileiros que querem e são e hão de ser grandes - enchendo o mundo com a fama de maior potencia americana, nascida da raça portugueza..." (BARROS, Portugal Maior, 1920: 11).

Barros iniciou o seu discurso dizendo que queria, antes de dar notícias de Portugal, saudar o Brasil que na vida literária, económica, no trabalho dos seus estadistas “... diz-nos hora a hora que de facto continúa mantendo, com um prestigio sempre crescente, a hegemonia que de direito possue em toda á America do Sul. Verifico esta realidade consoladora com orgulho e com desvanecimento" (BARROS, idem: 14).

Os temas escolhidos e o tom dedicado à conferência sugeria a afirmação de uma imagem positiva de Portugal perante à colónia. Não era para tratar das intrigas e da instabilidade política (bombas, greves) e nem da crise económica, já amplamente noticiada na imprensa numa campanha de descrédito do país. Queria, então, assegurar o poeta que em Portugal vivia, trabalhava e progredia "o mesmo povo de sempre - o povo de Viriato, o povo de Affonso Henriques... o povo victorioso e sincero, o povo excepcional e nobre da grande guerra do mundo!" (BARROS, ibidem: 16).

Barros buscava apresentar um país renascido e assim afirmava que não deveriam julgar Portugal decaído, empobrecido de alma e de fé. O que se via era o renascimento do patriotismo lusitano e uma intensa ressurreição da vida moral, intelectual, económica e comercial em meio a um dado caos em decorrência da Guerra (idem, ibid.: 22-23).

\footnotetext{
${ }^{71}$ Editada pela Livraria Francisco Alves, Rio de Janeiro, 1920.
} 
Após evocar as imagens líricas do país, o poeta expôs alguns dados acerca da indústria naval portuguesa e mencionou um movimento de regresso à terra. Enfatizou, ainda, os avanços no setor da educação, com a propaganda e medidas pró-instrução implementadas pela República, defendendo que o futuro de Portugal estava nas mãos da gente moça que estuda. Essa gente nova sonhava com a mais estreita aproximação com o Brasil, a qual se traduzia em conhecimento recíproco e intensa solidariedade intelectual (BARROS, Portugal Maior: 34-42).

Diante dessas conquistas, o Portugal verdadeiro, segundo Barros, é o "Portugal Maior", porque tomado de um impulso de força construtiva e não o país decaído que transparece nos telegramas estrangeiros (idem: 43-44). Daí podemos perceber qual o sentido atribuído ao título da conferência. Nesse caso, avaliamos que não ia ao encontro da ideia de uma superioridade cultural portuguesa em relação ao Brasil, conforme havia sugerido João Ribeiro em seu artigo.

Para dar continuidade a nossa reflexão sobre a visão nacionalista da Gil Blas, em confronto com a propaganda luso-brasileira nos voltaremos para a análise dos 12 marcos, os quais manifestavam a diretriz do semanário e as principais reivindicações das entidades que o mesmo representava. Esses pontos, conforme recorte, foram publicados inauguralmente no número em que se comemorou o primeiro ano do periódico:

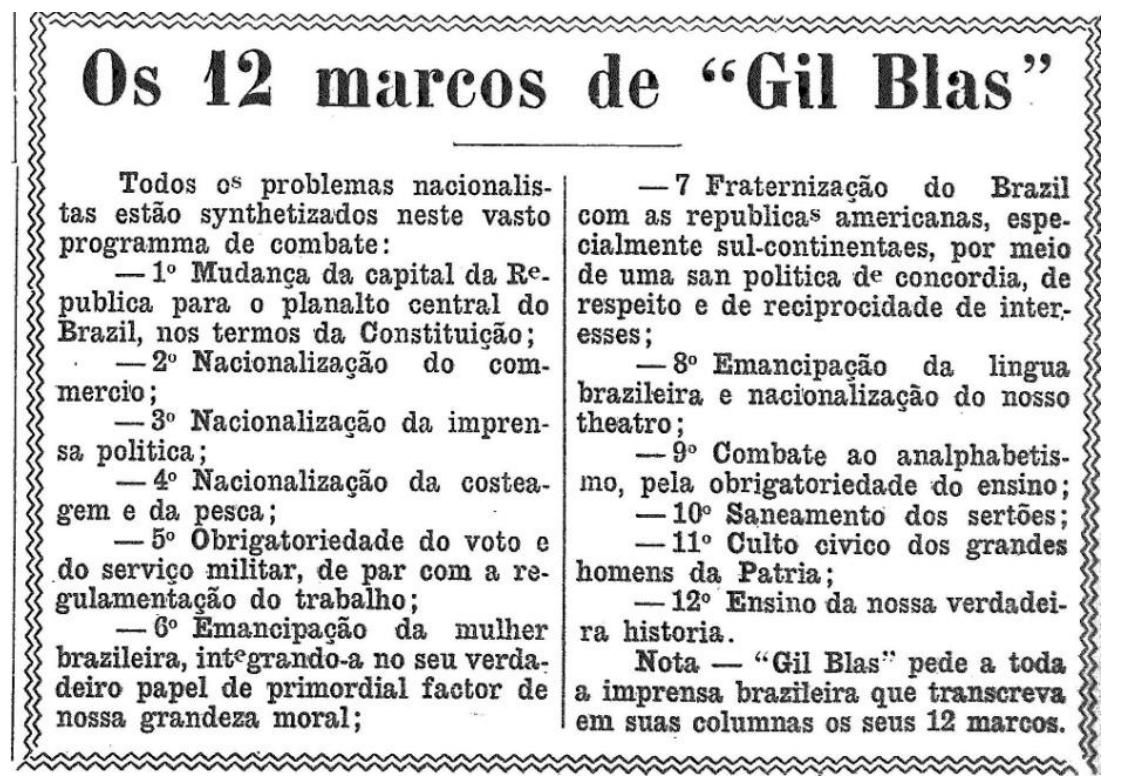

Gil Blas, 2/9/1920, № 82, p. 11. 
Todos os marcos foram devidamente apresentados em conferência realizada por Alcebíades Delamare, diretor e redator da Revista, no salão da Biblioteca Nacional do Rio de Janeiro, na noite de 10 de Setembro de 1920. Nos dedicaremos aqueles que se encontram relacionados às ideias anti-estrangeiras e anti-lusas. São eles: 1으 Mudança da capital da República para o planalto central, 2o Nacionalização do Comércio, 3ㅇN Nacionalização da Imprensa, 4ㅇ№cionalização da costeagem e da pesca, 8 Emancipação da língua brasileira e nacionalização do teatro e 12 E Ensino da verdadeira História brasileira.

Os três primeiros pontos do programa referem-se à hegemonia de capitais e influência lusa nos setores em questão: capital Federal (Rio de Janeiro), comércio e imprensa.

O primeiro, isto é, a mudança da capital do país para o Planalto Central, prevista na Constituição vigente na época, visava romper com o domínio do capitalismo estrangeiro, o qual se impunha no Rio de Janeiro. Esse capitalismo projetava a sua força no interior do parlamento nacional. Dirigia e orientava a opinião pública, porque detinha a hegemonia do comércio, o controle da imprensa e influenciava a política nacional sendo, portanto, nefasto ("Os doze marcos de 'Gil Blas'”, 29/9/1920, № 85: 5-6).

A nacionalização do comércio era a única forma, segundo Gil Blas, de romper com o capitalismo alienígena ${ }^{72}$ que monopolizava as atividades comerciais brasileiras. No Rio de Janeiro e nas capitais Manaus, Belém e Recife o comércio era todo estrangeiro, em geral lusitano. Sendo assim, não aceitava empregar os trabalhadores nacionais, chegando-se ao extremo de proibirem o casamento de seus empregados com brasileiras. Nesse setor desigual, nacionalizar o comércio significava promover a sua incorporação à economia nacional (idem: 6).

O terceiro ponto, a nacionalização da imprensa, buscava criar uma imprensa que pudesse atender às aspirações da sociedade brasileira. Naquele contexto, segundo Gil Blas, tratava-se de um segmento mercenário e alienígena que exaltava as fraquezas do

\footnotetext{
${ }^{72}$ Utilizou-se para se referir ao capital externo ou outras características estrangeiras os termos alienígena e exótico.
} 
povo brasileiro. Procurava caracterizar a raça brasileira como degenerada, ora alcoólotra, ora incapaz. Era a imprensa-balcão que favorecia somente àqueles que a financiavam.

Delamare colocava a seguinte questão: "Em que paiz culto do mundo estrangeiro goza desse prerrogativa perigosissima de orientar a opinião publica formando e dirigindo correntes de pensamento ... permitindo-se até a ousadia e a arrogancia de menoscabar vultos representativos da nacionalidade e de motejar dos mais alevantados effluvios de coração nativo?" (ibidem: 6). Citou, ainda, exemplos de alguns países que tomaram medidas contra qualquer tipo de intromissão estrangeira na imprensa.

Em termos de imagem é interessante cotejarmos a capa da revista "O carrapato é um symbolo" (abaixo) com as denúncias da hegemonia dos capitais portugueses no Brasil. Nessa caricatura evoca-se a ideia de uma relação parasitária, em que o português aparece como "sanguessuga" da população e dos recursos brasileiros.

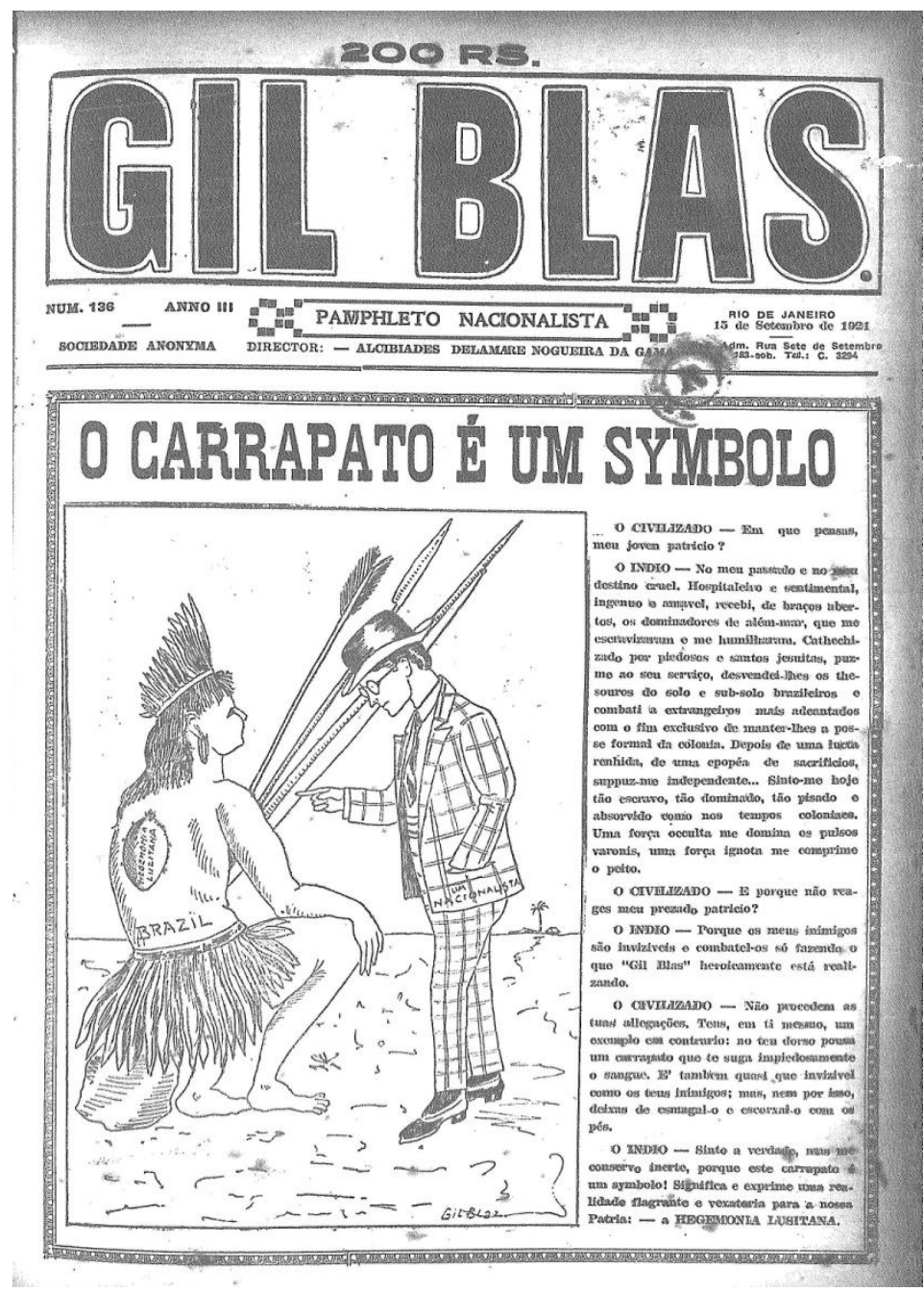

Gil Blas, “Capa”, 15/9/1921, № 136, Ano II. 
A questão da exploração é retratada por meio do diálogo entre um índio que representa o passado e o presente do Brasil e um nacionalista ("o civilizado"). O índio/Brasil traz um carrapato enterrado às costas onde se inscreve "hegemonia lusitana". Questionado pelo nacionalista o índio diz sentir-se “... tão escravo, tão dominado, tão pisado e absorvido como nos tempos coloniaes. Uma força oculta me domina os pulsos varonis, uma força ignota me comprime o peito". Apesar de reconhecer o parasitismo o índio/Brasil não reagia. Essa era uma forma de representar a força do domínio português em vários estratos da sociedade brasileira.

Nesse cenário, várias fontes e bibliografia identificavam os portugueses como monopolizadores de certos ramos do comércio a varejo, das profissões urbanas, das casas de aluguel, da imprensa, sobretudo no Rio de Janeiro. A partir dessa ideia de monopólio construiu-se visões de antilusitanismo alimentadas pelos movimentos nacionalistas radicais, as quais foram veiculadas pelos jornais e vivenciada pelos populares. No entanto, segundo Gladys Sabina Ribeiro:

“... Não há preconceito ou visões culturais tecidas em uma única e inequívoca direção. As imagens propaladas foram diferenciadas, construídas por todos os segmentos sociais a partir de vivências múltiplas e plurais. O português era 'trabalhador', 'morigerado', 'ordeiro', tanto por ser proprietário como assalariado exemplar, deixando-se explorar. Como 'indivíduo pernicioso', era tido como 'monopolizador', 'solapador', das tentativas de ordenação social da nascente República, tanto por controlar estabelecimentos comerciais e de moradia quanto por garantir, na maioria das vezes, empregos privilegiados. No dia a dia das ruas questionam-se os direitos dos portugueses e dos outros estrangeiros, em geral, beneficiados com a ideologia da 'modernização' e 'branqueamento' "(1994: 645).

Dando continuidade ao programa da Gil Blas, o quarto ponto; a nacionalização da costeagem e da pesca encontrava-se em processo de aplicação da lei em vigência desde o início do Governo Epitácio Pessoa, em 1919. Nessa parte alertava Gil Blas, apesar dos avanços registados, para o facto de que a maior parte das empresas de transporte marítimo do país encontrava-se nas mãos dos estrangeiros, embora ostentassem o título de nacionais. Seus lucros emigravam para a Europa, seus navios eram comandados por oficiais estrangeiros e a maioria da tripulação era exótica. 
A situação da pesca também era alarmante, segundo Gil Blas. Os pescadores brasileiros eram escravizados pelos portugueses, donos dos barcos geleiros no Norte do país. Diante desse cenário, citava a importância das missões empreendidas pelo Comandante Frederico Villar ao fazer cumprir a lei de nacionalização da pesca, garantindo que essa atividade poderia ser exercida somente por brasileiros ou estrangeiros naturalizados. Referia, ainda, que antes de tais medidas o Brasil importava anualmente cerca de 125 mil contos em peixes e produtos de indústrias congéneres (“Os doze marcos de 'Gil Blas'”, 29/9/1920, № 85: 6-7).

Nesse contexto de reivindicações de políticas de cunho nacionalizante, a Marinha de Guerra, sob liderança do Capitão de Mar e Guerra Frederico Villar, foi incumbida de implementar a lei que nacionalizava e regulava os serviços de pesca, no prazo de quatro anos. Sendo assim, o capitão, membro da Ação Social Nacionalista, tinha como tarefa: "reunir os pescadores em colônias ou cooperativas; profissionalizar os processos de pesca; proteger a fauna e a flora marinha e lacustre; estimular o aproveitamento dos produtos aquáticos; criar escolas; fundar postos de saúde; promover o saneamento e a defesa de toda a costa do país e exigir a naturalização dos estrangeiros dedicados à pesca" (VILLAR apud Almeida, 2010: 185).

Deve-se ressaltar que a pesca no país era predominantemente exercida por portugueses originários de Póvoa de Varzim ("os poveiros"), sobretudo no Rio de Janeiro e no Pará. Em Santa Catarina, por portugueses açorianos e no litoral de São Paulo e de Cabo Frio por pescadores japoneses. Para regularizar o processo foi elaborada circular em 5 de Agosto de 1920, que estabelecia o prazo de 90 dias para os pescadores estrangeiros naturalizarem-se, sendo que para São Paulo, Rio de Janeiro e Espírito Santo foram concedidos 60 dias.

Esse facto alimentou os ressentimentos entre portugueses e brasileiros, produzindo visões críticas quanto à defesa de um estreitamento das relações lusobrasileiras. À medida que o capitão Villar fez vigorar a circular e começou a negar a matrícula de pesca aos portugueses houve uma mobilização por parte da comunidade lusa em campanha a favor dos poveiros, com grande repercussão na imprensa carioca. 
O caso, levado a tribunal por alguns pescadores portugueses, gerou imensas polémicas e polarizou a questão. De um lado encontrava-se a comunidade lusa, comandada pelo Embaixador Duarte Leite, que se colocava contra as naturalizações e do outro, favorável ao cumprimento da lei; o Governo brasileiro, as organizações do nacionalismo nativista e seus apoiadores (SABINA RIBEIRO, 2001: 154).

Dentre os episódios extremos que marcaram a intensa batalha na questão dos poveiros, deu-se a agressão do capitão Villar a João do Rio $^{73}$, este último defensor aguerrido dos pescadores portugueses. Contudo, os poveiros acabaram por deixar o país sob o lema: "Antes sem pão do que sem pátria" (SABINA RIBEIRO, idem: 155).

Apesar dessas manifestações antiportuguesas, João de Barros in O Sentido do Atlântico avaliava o nativismo brasileiro como a expressão transitória do ódio de uma minoria e a "questão dos poveiros senão como um incidente digno de energicas sanções, não traduzindo, porém, o sentimento colectivo do Brasil a nosso respeito" (1921: 14-15). Dizia ainda, que o " gesto do comandante Vilar não foi a sintese nem a resultante do sentimento do Brasil para conôsco: - foi unicamente um gesto isolado, um gesto pessoal, correspondendo a uma corrente isolada de umas centenas de inimigos nossos" (idem: 65-66).

O oitavo marco da Gil Blas, emancipação da língua brasileira e nacionalização do teatro, incidem sobre esses dois símbolos da nacionalidade. Nesse sentido, defendia que se adotasse oficialmente a designação de língua brasileira para o idioma falado no país. Desse forma, dar-se-ia o rompimento com os convencionalismos que vinculavam o idioma brasileiro ao idioma português. Esta medida impunha-se como legítima, visto que não se falava o português no Brasil, mas uma "lingua sonora, melodiosa e cantante [...] rica e fertil de vocabulario criado e formado em solo livre da America, ao calor do sol germinador dos tropicos, não é positivamente a mesma que

\footnotetext{
${ }^{73}$ “Villar e seus apaniguados entraram quase marchando pelo fino restaurante [onde se encontrava João do Rio], assustando garçons e clientes. Dirigiam-se diretamente para a mesa do jornalista... Antes que João do Rio pudesse responder uma saraivada de socos e bengalas o atirou no chão do restaurante, onde ainda foi chutado na cara, no fígado e na bunda. Com a mesma soberba com que entraram, os agressores retiraram-se antes que juntasse muita gente, aos gritos de 'Nacionalismo ou morte' e outras palavras de ordem..." (RODRIGUES, João Carlos, 1996: 243).
} 
ouvireis nas ruas de Lisbôa ou nas ribas de Traz os Montes" ("Os doze marcos de "Gil Blas'”, 29/9/1920, № 85, p. 8).

Quanto ao setor teatral, era preciso nacionalizar e fundar o teatro brasileiro, pois as companhias estrangeiras ocupavam todas as salas do país. Nessas circunstâncias, não havia espaço para o empresário nacional. Somente as medidas de nacionalização poderiam garantir a adoção da prosódia brasileira, a recompensa devida aos escritores nacionais e a proteção aos atores brasileiros (idem: 8).

O décimo segundo ponto do programa referia-se ao ensino da História brasileira. Nessa questão argumentava-se que a história ensinada nas escolas brasileiras constituía-se num amontoado de "mentiras e de falsidades cívicas", com o propósito de preservar a memória da antiga metrópole.

Citava como exemplos desse versão tendenciosa da história a exaltação dos personagens de Pedro Álvares Cabral e D. Pedro I (D. Pedro IV em Portugal). Nesse sentido, reforçava a ideia de que Colombo tinha sido o descobridor do Novo Mundo e assim deveria ser ensinado. Não deveria ser conferida todas as glórias desse evento à Cabral, visto que outros navegadores já haviam estado em terras brasileiras antes do navegador português (ibidem: 9).

Quanto a D. Pedro I, não deveria ser celebrado como o herói da Independência brasileira, pois efetivamente não tinha participação nessa obra. Havia apenas encenado tal envolvimento, como forma de burlar o movimento de emancipação. Diante disso, afirmava: "o ensino da nossa verdadeira historia... deve ser feito escrupulosamente nas escolas, de forma que o espirito dos jovens não se illuda, confundindo um interesse millenar com uma amizade que não existe, senão na letra de forma e quando muito nas letras... promissorias ou bancarias" (idem, ibid.:9).

Embora as leituras em torno da presença portuguesa no Brasil tenham sido múltiplas, evidenciou-se um recrudescimento das manifestações xenófobas e lusófobas na conjuntura nacionalista do pós I guerra. O português era mais uma vez no contexto da I República brasileira o bode expiatório responsável pelos males da vida do país. 
Na década de 1890, a questão era a consolidação do então novo regime político e o português representava o perigo de regresso da monarquia. Nos anos de 1920, o país buscava edificar-se como nação e garantir o progresso, em meio a crise económica, a crescente carestia e a alta inflação. Nesse período, o antilusitanismo manifestava-se nas disputas de mercado de trabalho e na esfera do alto comércio do Rio de Janeiro. "O problema crucial era deter o português 85 por cento do comércio da cidade, segundo Antônio Torres, e mandar sua fortuna para Portugal, ou em pequenas remessas, ou quando para lá voltava, depois de velho..." (TORRES apud SABINA RIBEIRO, 2001: 156).

De acordo com Gladys Sabina Ribeiro, ao analisar os jornais da época, havia uma tendência em afirma-se ou negar-se os conflitos entre brasileiros e portugueses, de ambos os lados, recorrendo-se a justificativas para os desentendimentos. Nessa linha de interpretação, podemos situar o posicionamento de João de Barros que buscava minimizar tais conflitos e relativizar os impactos da campanha nativista brasileira e sua imprensa. Dizia então o paladino da união luso-brasileira acerca da sua segunda viagem ao Brasil e suas impressões nesse sentido:

"Afirmando por toda a parte a conveniencia da aproximação luso brasileira - não ouvi senão palavras de simpatia e de adesão ás minhas afirmações... Não exagero, nem minto - como é, de resto, facil de verificar pelo relato dos jornais durante a minha estada no Brasil. Nesse tempo, no entanto, já havia a campanha do Gil Blas... Conseguiu ela agora resultados mais eficazes? Certamente. Mas esses resultados foram logo inutilizados - nunca é demais repeti-lo pela atitude, francamente lusofila, de todo o resto da imprensa brasileira" (O Sentido do Atlântico, 1921: 65-66).

Nesta primeira parte do trabalho, buscamos introduzir o pensamento de João de Barros acerca da aproximação luso-brasileira, a partir das questões propostas em duas das obras da Campanha Atlântica: Energia brasileira e Sentido do Atlântico.

Num segundo momento, concentraremo-nos nas temáticas apresentadas na revista Atlântida (1915-1920). Órgão pensado a partir da referência vitalista, criado e dirigido por João de Barros e João do Rio. O mensário tinha como objetivo promover a aproximação cultural entre Portugal e Brasil. Visava-se, por meio desta colaboração, eliminar o distanciamento e desconhecimento mútuos. 
Outras revistas do período com orientações político-ideológicas diversas, embora não tenham sido formuladas com o mesmo propósito da Atlântida, também discutiram as relações luso-brasileiras. Referimo-nos referimos à Águia (1910-1932) e a Nação Portuguesa (1914-1938). Neste sentido, é importante colocar essas visões em diálogo e perceber as convergências e divergências em relação ao tema. Incluiremos, ainda, a publicação brasileira de cariz lusófobo; Gil Blas nesse debate.

\section{CAPÍTULO II.}

\section{REVISTA ATLÂNTIDA E OUTRAS VOZES: PELA APROXIMAÇÃO ENTRE PORTUGAL E BRASIL}

Conforme vimos, a versão que reconhecia a importância da tradição portuguesa como formadora da identidade brasileira, reforçou os elementos culturais comuns e criou espaço para o discurso do luso-brasilismo, luso-brasileirismo ou lusobrasilidade enunciado por intelectuais de ambos os países.

Buscamos, nesse capítulo, recuperar como foram pensadas as relações entre Portugal e Brasil, em diferentes vozes, nas primeiras décadas do século XX. Neste contexto, destacou-se a forma como a "causa luso-brasileira" ganhou espaço e projeção, estimulada por um vigoroso debate entre grupos de intelectuais. Tais grupos fundaram revistas, em ambos os países, as quais divulgaram os seus pensamentos. Nesse contexto, a revista Atlântida, publicada em Lisboa, entre os anos de 1915 a 1920, constituiu-se como importante espaço dessa discussão:

“Parece-me que o fim des'ta Revista é fortemente dissipar preconceitos e ignorancias e fazer com que as criticas respectivas acompanhem reciprocamente o movimento intelectual, politico e literario dos dois paizes.

É de facto uma obra necessaria. E é uma obra principalmente oportuna. Porque é preciso dizer com franqueza que os nossos paes quando eram jovens se preoccupavam muito mais com a literatura portugueza do que nós outros. Convém, portanto, receber a cooperação literaria e intelectual, a fim de manter e estreitar a cooperação economica e social - tão eficiente, tão de acordo com os nossos destinos independentes mas harmonicos; tão necessaria a brazileiros e portuguezes" (VIANA, Atlântida, n22, 1915: 102). 
A Atlântida, cujo subtítulo era mensário artístico literário e social para Portugal e Brasil, foi pensada com o propósito de suscitar um intercâmbio cultural entre os países. A revista nasceu da união entre dois expoentes das letras com a crença comum de renovar e intensificar as relações luso-brasileiras. Como é sabido, estamos a referirnos a João de Barros e a João do Rio.

Diante da documentação consultada, acreditamos que o periódico apresenta-se como relevante ao considerarmos o conteúdo, o volume e a longevidade da sua publicação, ao lado do patrocínio dos governos dos dois países. Foram publicados quarenta o oito números, ao longo dos cinco anos de sua existência. Os mesmos eram editados mensalmente, salvo situações de atraso, nas quais reuniam-se mais de um número num mesmo mês.

É interessante considerarmos brevemente a terminologia revista enquanto modelo de periódico inventado na França e seguido em Portugal e no Brasil. A revista é um tipo de publicação que se diferencia do livro, do jornal, do semanário pelo tamanho, tipo de diagramação, número de páginas e modo de produção em grupo. Constituiu-se, ainda, como um "lugar privilegiado para uma re-leitura do seu próprio tempo ao re-visitar os assuntos que, num determinado contexto, mais interessaram a sociedade na qual era produzida" (Clara Rocha apud Müller, 2011: 28).

João de Barros assumiu a direção da revista em Lisboa em parceria com João do Rio, responsável pelo mensário no Rio de Janeiro. Essa colaboração manteve-se durante todo o percurso do periódico. No entanto, Barros destacou-se como figura que deu formato e garantiu a manutenção da revista nas fases de crise que ameaçaram a continuidade da publicação.

Ao acompanhar as temáticas discutidas na revista Atlântida, podemos inferir que a ideia da aproximação cultural foi o mote, no entanto, respaldada por uma questão também política. Algumas leituras sugerem a interpretação de que as elites luso-brasileiras que conceberam o mensário vislumbravam a consolidação de uma relação política, económica e cultural que privilegiasse uma interação via Atlântico Sul entre Brasil, Portugal e suas então colónias africanas. Uma espécie de aliança, com vistas ao cenário internacional, em termos de zonas de influência na política externa e 
de posicionamento estratégico. Essa ideia assumiu diferentes configurações, conforme veremos mais adiante.

\section{II.1. Nasce a Atlântida}

Os projetos político-culturais dos finais do XIX e primeiras décadas do XX e as elites por detrás dos mesmos, devem ser compreendidos na perspectiva das grandes utopias. O conceito de utopia, nesse sentido, remete a ideias e projetos possíveis, que vingaram ou não consoante às tensões presentes nas realidades sociais nas quais estiveram inseridos. É neste contexto, no qual os intelectuais sentiam-se verdadeiramente responsáveis pelos rumos dos seus países e não poupavam esforços para exercerem os seus papéis de mobilizadores sociais, que devemos situar as trajetórias de João de Barros e João do Rio. Aquilo que os unia era a crença na causa da aproximação luso-brasileira. Nessa perspectiva, nos intriga perceber como as diferentes e, por vezes, divergentes visões sobre essa aproximação dialogaram.

Barros em artigo inaugural, no primeiro número da Atlântida, definia o seu olhar acerca das relações entre Portugal e Brasil:

“... Mas eu via isto: um enorme paiz unico, separado pelo Oceano, um só paiz imenso, que na Europa tivesse as raizes indispensaveis d'uma tradição, e na America a energia, a fé, o amor, ainda mais indispensaveis, da juventude permanente e creadora! Esquecia as historias rabujentas, que ás vezes me contavam de desinteligencias entre portuguezes e brazileiros. Esquecia a distancia. Esquecia a má vontade que certos elementos estrangeiros teem procurado dispertar entre as duas nações. Esquecia a inercia estupida de certos governos nossos..." (1915: 6).

Constituía-se como problemático, aos olhos do escritor, o afastamento que pairava entre os dois povos. Apesar da tradição cultural partilhada, havia um desconhecimento mútuo em vários campos da vida cultural e política que era necessário ser reparado. A revista tinha então a meta de fomentar um reencontro entre os dois povos, ao estabelecer um diálogo profícuo que pudesse desnudar "as almas" brasileira e portuguesa (BARROS, idem: 8). Propunha-se um canal de 
comunicação, que conseguisse transpor os limites da retórica, traduzindo-se em ação de esclarecimento sobre a literatura e os fatores de progresso intelectual e social promovidos nos dois países:

“D'este modo, a Atlantida surge com um pouco de espirito aventureiro dos velhos navegadores portuguezes e com muita energia ardente e moça que deu ao Brazil o seu explendor de civilisação. E em frente do Mar - que, n'esta hora de sol pleno, é todo uma fulguração de luz triumphante - não duvido já dos destinos da Atlantida: - ela será como uma grande voz, de multiplos echos, a vibrar na mesma palavra de amor sobre as duas margens distantes do vasto Oceano, que a leva cantando, e cantando a faz voar d'onda em onda" (Atlântida, ibidem: 9).

A escolha do nome do mensário remete à mítica Atlântida. A ilha onde teria habitado uma rica civilização, maior do que a Ásia e a África. Citada pela primeira vez nos diálogos Timeu e Crítias de Platão, aparece no relato como um grandioso Império Marítimo situado no Oceano Atlântico, além das Colunas de Hércules, Estreito de Gibraltar. Em confronto com Atenas, a potência insular fora derrotada e teria sido atingida por um dilúvio e assim desaparecera no Oceano que mantém o seu nome. Esse mito povoou o imaginário dos povos ao longo dos diferentes períodos da História e gerou inúmeras interpretações acerca da sua existência e localização ${ }^{74}$.

Segundo Janise Paiva, a escolha dessa referência para nome da revista remetia à terra marítima portuguesa. O mito da Atlântida é "revisitado enquanto via e viés para se ler o caráter marítimo e expansionista de um Portugal em fase de 'decadência' e possível 'renascimento' republicano...' (2001: 188).

Nas palavras de João do Rio, a ideia da Atlântida evocava a epopeia portuguesa dos descobrimentos: "[...] Os iberos vieram por ella e foram muito alem plantar noutro continente a semente da energia, criando outros povos" (Atlântida, no1, 1915: 15). Ainda segundo o escritor, esse paradigma devia ser pensado à luz dos poetas e sonhadores coletivos que sempre acreditaram na existência da Ilha. Assim a revista nascia como:

\footnotetext{
${ }^{74}$ Uma interessante discussão acerca do mito da Atlântida pode ser conferida em "A Atlântida e as Nações". In: Pierre Vidal-Naquet. A Democracia Grega: ensaios de historiografia Antiga e Moderna. Lisboa: 1993.
} 
“... a terra abstrata do conhecimento, do saber, da advinhação; Atlântida é o élo dos sentimentos que se harmonisam a musica onde as nove musas se debruçam para o sorriso da humanidade, o grande abraço mental entre a Europa e a América" (idem: 15).

De acordo com estudo de Cecília Conceição, o periódico veiculava uma imagem de vanguarda e de tradição, predominando o viés tradicionalista. O lado da invenção estava presente no desejo da universalidade, identificado na iniciativa de se promover a amizade entre os povos (1997: 32).

Não nos deve escapar o facto da Atlântida ter sido fundada alguns meses após a modernista $O_{r p h e u^{75}}$ e também a repetição do modelo de direção; um diretor no Brasil e outro em Portugal. No entanto, a orientação estética entre as duas revistas era completamente divergente. A Atlântida esteve mais ligada ao academismo e, quase por completo, fechada à modernidade literária (SARAIVA, 2004: 124-125).

O "mensário artístico, literário e social para Portugal e Brasil" configurou-se como uma revista voltada para a literatura, as artes e intervenção social. Buscava propor formas de solucionar as questões que pudessem interferir na promoção da amizade luso-brasileira, sempre guiada por um ideal nacionalista e republicano (CONCEIÇÃO, 1997: 32).

Quanto ao conteúdo da Atlântida, Fernanda Müller (2011) em tese sobre um conjunto de revistas portuguesas ${ }^{76}$ que circulavam no Brasil, entre os finais do século XIX e os anos de 1920, classificou-a como híbrida. Apresentava, portanto, conteúdo diversificado, abarcando temáticas nas áreas da economia (comércio, emigração), literatura, educação, política e cultura.

\footnotetext{
75 Orpheu foi uma revista trimestral de literatura editada em Lisboa, em 1915. Apenas dois números foram publicados, sendo o terceiro cancelado devido a dificuldades de financiamento. Embora com breve duração, teve importante influência ao introduzir em Portugal o movimento modernista. Destinada ao público português e brasileiro, teve como diretores Luiz de Montalvôr (para Portugal) e Ronald de Carvalho (para o Brasil) e como editor o, então, jovem escritor António Ferro. Fizeram parte do seu quadro de colaboradores: Fernando Pessoa, Mário de Sá-Carneiro e José de Almada Negreiros, dentre outros.

${ }^{76}$ Revistas analisadas pela autora: Atlântida, Brasil-Portugal (1899-1914), Orpheu (1915), A Rajada (1912) e a Nação Portuguesa (1914-1938). Conferir, MÜLLER, Fernanda Suelly. (Re)vendo as páginas, (re)visando os laços e (des)atando os nós: as relações literárias e culturais luso-brasileiras através dos periódicos portugueses (1899-1922). Tese de doutorado, Programa de Pós-Graduação em Literatura Portuguesa, FFLCH/USP, São Paulo, 2011.
} 
Dentre as discussões relevantes nas páginas da revista podemos citar: a I Grande Guerra e as relações luso-brasileiras, Confederação Luso-brasileira, relações e interesses económicos-comerciais, intercâmbio artístico-literário (artes, literatura, música e ensino), cultura e tradição histórica, personalidades e estadistas, política externa e relatórios consulares, campanhas patrióticas, legislação brasileira, catolicismo, Igreja e Estado no Brasil. Podemos assim constatar que o periódico inseriu-se em debates mais amplos do que a causa da aproximação luso-brasileira, em nome da qual fora criado.

Do ponto de vista estético-literário prevaleceu o espírito tradicional-académico e a colaboração literária, tanto portuguesa como brasileira, não trazia novidades ou marcos genuínos. Do lado brasileiro, embora a participação tenha sido reduzida, enviaram contribuições: João do Rio, Medeiros e Albuquerque, Júlia Lopes de Almeida, Graça Aranha, Basílio de Magalhães, Tristão Ataíde, Olavo Bilac, Carlos Laet, Afrânio Peixoto, Antônio Torres, João Lage, João Luso, dentre outros. Do lado luso, podemos citar: João de Barros, Guerra Junqueiro, Joaquim Manso, Henrique Lopes de Mendonça, Alberto de Oliveira, António Patrício, Manuel de Sousa Pinto, João de Deus Ramos, Luís Câmara Reis, Aquilino Ribeiro, António Sérgio, Jaime Cortesão, Raul Proença, Nuno Simões, Teófilo Braga, Júlio Dantas, Carlos Malheiro Dias, dentre outros.

Um breve inventário das matérias publicadas na revista revela a presença de nomes de reconhecida reputação no campo literário luso-brasileiro, conforme indicado. Ao lado disso, percebe-se que tais escritores representavam correntes estéticas e teóricas diversas. O ecletismo indicado atendia ao propósito anunciado por João de Barros de abertura do mensário a todos os quadrantes do mundo letrado, no entanto, mantinha-se a diretriz republicana. A mistura de tendências visava atrair novos simpatizantes para a causa da revista e conquistar um público leitor mais numeroso (GUIMARÃES, 2011: 139).

Devemos referir, que registaram-se diferentes tipos de colaborações na revista. Havia os colaboradores promotores, os convidados e os programáticos. Os promotores, sobretudo, João de Barros e João do Rio, dedicaram-se a promover e a 
divulgar o periódico. Os colaboradores convidados representavam nomes conceituados no mundo literário, geralmente com pequena participação, no entanto, suficientes para conferir prestígio e boas vendas à publicação. Dentre os mesmos, podemos citar: Teófilo Braga, Guerra Junqueiro, Teixeira de Pascoaes, António Sérgio, Olavo Bilac, Afrânio Peixoto, dentre outros. Os programáticos dedicavam-se ao programa da revista.

As grandes linhas programáticas da Atlântida podem ser resumidas nas seguintes propostas: a promoção da amizade luso-brasileira, em seus diferentes aspectos e a discussão de temáticas sócio-políticas ligadas à educação e à guerra. No que concernia a aproximação entre Portugal e brasil, a revista buscava soluções para os problemas que impediram a celebração de acordos no passado das relações luso-brasileiras.

Segundo os artigos do periódico, os principais entraves que dificultavam os acordos entre os países eram: a inexistência de uma linha de navegação regular entre Portugal e Brasil ${ }^{77}$ e a falta de implantação de uma política emigratória que garantisse condições para a valorização humana e profissional do emigrante luso. Nesse sentido, a elaboração de um programa de política comercial entre Portugal e Brasil dependia da resolução dessas questões fulcrais (CONCEIÇÃO, 1997: 38).

Acerca da emigração portuguesa para o Brasil escreveu o diplomata, político e economista português Veiga Simões (1888-1954). Dentre os vários cargos exercidos por Simões, a passagem pelos Consulados portugueses de Manaus e Belém agregou conhecimentos em torno das relações luso-brasileiras.

No longo artigo intitulado "Programa de Política Comercial com o Brasil", o autor chamou a atenção para o facto de que a balança comercial portuguesa dependia do fruto das economias dos emigrantes que, por sua vez, encontravam-se condicionados pelas incertezas da economia brasileira do período. De acordo com Simões, dentre as várias questões tratadas, não havia qualquer controle oficial da emigração, a qual ocorria como um verdadeiro êxodo sem qualquer organização:

\footnotetext{
77 Conferir, por exemplo, CARVALHO, Mario. "Navegação entre Portugal e Brazil”, in: Atlântida, no 1, 1915, pp. 83-84. TELLES, Moreira. "Relações luso-brazileiras”, in: Atlântida, no 1, 1915, pp. 64-65.
} 
“... Lançado numa terra ao deus dará, sem o menor carinho do país que o viu partir, sem o menor interesse do país que o recebeu, é assim um joguete das forças sociais, é bem o homem que vai a procura da sorte e que as mais das vezes tomba sem a encontrar. Nas grandes cidades, bazares formidaveis, onde de meio mundo se vai atraz da fortuna; é um joguete da luta; no interior de clima brando, ou se adapta a vida rude como um sertanejo nato, ou consegue subir mercê de sua esperteza, até chegar a familiar das autoridades, e ele proprio autoridade também..." (Atlântida, no 44-45, 1919: 19).

Diferentemente dessa situação, observou o autor, encontravam-se os emigrantes italianos, japoneses e alemães. Nesses casos, eram adotadas políticas por parte dos respetivos Governos, as quais estabeleciam previamente contratos de trabalho. Garantia-se, dessa maneira, maior controle e meios de integração desses emigrantes ao novo país.

Em linhas gerais, o imigrante luso instalava-se nas cidades litorâneas e inseriase nas atividades urbanas. Esse facto gerou imensas críticas por parte dos movimentos nativistas brasileiros, os quais alegavam a necessidade de mão-de-obra nas lavouras do interior. Malheiro Dias, em entrevista à Atlântida, abordou tal característica da imigração lusa e defendeu que os portugueses deveriam seguir o fluxo da expansão brasileira, reordenando-se às atividades do campo: "O Brasil vai lançar-se para o Interior... Para não ser arremessada aos máres, a Colónia Portuguesa tem de acompanhar a época, ir para o interior, tomar o seu lugar, não se deixar vencer pelas outras colonizações" (Malheiro Dias, Atlântida, no 19, 1917: 603).

É importante ter em consideração que os imigrantes eram vistos como agentes da preservação da cultura portuguesa no Brasil. Paradigmaticamente ocupavam o lugar do "entre", nem lá e nem cá, assim como a própria revista. Miticamente, os mesmos, “personificam o grande abraço mental entre Brasil e Portugal” (PAIVA, 2001: 191-192).

Segundo Janise Paiva, num cenário de exaltação dos sentimentos nacionais portugueses e de grande patriotismo, a luso-brasilidade da Atlântida desenvolver-se-á e perder-se-á. A revista divulgava uma imagem de Portugal que destacava as suas particularidades e riquezas nacionais, e com essa propaganda do país visava a 
aproximação com o Brasil. Nesse sentido, "Atlântida será uma divulgação algo panfletária de Portugal, aquém e além mar" (idem: 190)

Em artigo sobre "Portugal, o Brasil e as colónias portuguesas", João de Barros dizia discordar da afirmação do jornalista Joaquim Manso $(1878-1956)^{78}$, na qual o mesmo defendeu que dever-se-ia pensar menos no Brasil e mais nas colónias. Para Barros, ao se buscar o progresso económico de Portugal, era preciso pensar simultaneamente no Brasil e nas então colónias portuguesas. Era possível e vantajoso para ambos os países o estabelecimento de acordos de preço em relação a produtos comuns. Esta era uma forma de contornar as questões que se colocavam em relação à concorrência entre os produtos agrícolas brasileiros e os coloniais.

Nesse sentido, segundo Barros, fortalecer os laços com o Brasil poderia garantir maior prosperidade económica para as colónias. Portanto, tais preocupações "só demonstram um esclarecido amor da Pátria - e provam que entre nós se compreende, enfim, o direito que nos pertence a um valioso quinhão no domínio do Atlântico Sul, domínio com que só poderemos vantajosamente participar na plena comunhão de interesses com o Brasil" (Atlântida, no 40, 1919: 499).

A Atlântida destacou-se ainda pela ousadia do projeto editorial. Apesar das dificuldades no plano interno e externo, manteve-se como uma publicação mensal, ao longo de cinco anos de edição. Era uma revista de elites e para elites. Os recursos financeiros advinham, provavelmente, das assinaturas, de alguma publicidade e dos apoios e colaborações voluntariosas dos seus promotores. Cada número da Atlântida apresentava em média 100 páginas, que seguiam uma numeração contínua dentro de cada ano de edição. Não se registou informações acerca da tiragem ${ }^{79}$.

O patrocínio governamental pode ser conferido nas dedicatórias dos Ministros das Relações Exteriores do Brasil e dos Estrangeiros e Fomento de Portugal. Fez-se

\footnotetext{
${ }^{78}$ Fundador do Diário de Lisboa (em 1921), manteve-se como diretor do jornal ao longo de 35 anos. Notabilizou-se, ainda, como escritor e ensaísta. Colaborou em diversas publicações periódicas, tais como a revista Arte\&vida (1904-1906) e a Atlântida. Foi sócio correspondente da Academia das Ciências de Lisboa e professor do Conservatório Nacional de Lisboa.

${ }^{79}$ CORREIA, Rita. Ficha Histórica: Atlântida - mensário artístico, literário e social para Portugal e Brasil. Disponível em: http://hemerotecadigital.cm-lisboa.pt/OBRAS/Atlantida/Atlantida.pdf , consulta em 19/2/2013.
} 
presente desde a primeira edição, seguidas da mensagem de apoio impressas nas páginas iniciais dos números posteriores, em vigor até o vigésimo quinto exemplar de 1917. Esse aspecto introduziu um condicionante no direcionamento da revista, caracterizando-a como um órgão oficial em consonância com os governos republicanos instaurados.

Em função desse direcionamento político, alguns episódios importantes presentes nas sociedades portuguesa e brasileira do período não foram abordados na Atlântida. Por exemplo, não foi feita nenhuma referência ao golpe que culminou no Governo de Sidónio Pais (Dezembro de 1917 a Dezembro de 1918), assim como manteve-se silêncio acerca da revolta monárquica do Norte, ocorrida em Janeiro de 1919. Embora João do Rio, diretor da revista, estivesse no Porto nessa altura, onde dedicou-se a acompanhar o movimento e a produzir reportagens sobre o mesmo, nenhuma dessas matérias foram publicadas no mensário. Note-se, ainda, que foram feitas considerações muito ligeiras sobre as manifestações lusófobas no Brasil, dandose pouca visibilidade ao tema (CONCEIÇÃO, 1997: 29-30).

Conforme dissemos anteriormente, as questões da conjuntura nacional e internacional estiveram em relevo na Atlântida. Isto pode ser observado, por exemplo, no destaque conferido aos temas que tratavam da I Guerra Mundial, os quais assumiram um espaço considerável nos conteúdos da revista.

Inclusive, devemos questionar em que medida este cenário instável, tanto do ponto de vista interno quanto externo, contribuiu para a materialização do periódico que havia sido idealizado pelos escritores-diretores, "os Joões", alguns anos antes ${ }^{80}$. Dito de outra maneira, como as crises de consolidação e unificação do Regime Republicano Português e as incertezas produzidas por uma Guerra Mundial ajudaram a mobilizar setores da diplomacia de ambos os países a apoiar uma revista em prol da aproximação luso-brasileira?

\footnotetext{
${ }^{80}$ O projeto remetia ao ano de 1908 , quando realizou-se a primeira viagem de João do Rio à Portugal. Nessa altura o jornalista brasileiro foi apresentado a João de Barros pelo escritor Manuel de Sousa Pinto e assim foram travados os primeiros contactos e esboçadas as ideias em torno da revista que se pretendia criar.
} 
Uma nota da direção, ao final do primeiro número do periódico, falava das tentativas frustradas em busca do suporte financeiro e editorial para fazer vingar o projeto em torno do mensário. Considerava neste percurso, as circunstâncias criadas pela guerra europeia determinantes no movimento de solidariedade entre os povos que partilhavam uma mesma tradição cultural ou que descendiam "do mesmo tronco originário". Recorria ainda à herança latina comum aos dois povos; "... Dentro da vasta familia latina - o Brazil e Portugal são, mais que nenhuns outros paizes, fraternaes e similhantes" (1915: 94).

João de Barros assumiu um dado protagonismo nestes conteúdos relativos à Grande Guerra, ao realizar grande parte das entrevistas com Ministros dos Negócios Estrangeiros, Ministro da Guerra e outros representantes do Governo Republicano Português.

Numa das primeiras sessões de entrevistas intituladas Portugal e a Guerra, Barros lançava questão ao então Ministro dos Negócios Estrangeiros, Augusto Soares, a respeito da repercussão política diante da ato do Governo Português ao requisitar os navios alemães a pedido da Inglaterra. Melhor dizendo, o escritor indagava se tal medida "concorrera de modo decisivo para a consolidação da República, tanto interna, como externamente?" (Atlântida, no 6, 1916: 506).

Desde o princípio do conflito mundial em 1914, o debate em torno do caminho a ser adotado por Portugal; intervir ou não? dominou a cena republicana. E a questão central nesta campanha intervencionista era a de se promover uma unidade entre as diferentes fações republicanas, em constante conflito desde a instauração da República em Outubro de 1910. O clima instável produzido pelas inúmeras tentativas golpistas contra o Governo Republicano e as divergências dentro da própria "família" republicana não contribuíam para se conquistar um respeito pelo novo regime, nem a nível interno nem externo.

Logo após o confisco dos navios dos Impérios Centrais, conforme invocado pela Grã-Bretanha, a Alemanha declarou guerra a Portugal, em março de 1916. Sendo assim, fora ultrapassada a resistência diplomática britânica à beligerância portuguesa e 
os setores pró-intervencionismo ${ }^{81}$ venciam a sua batalha. No início de 1917 , partia para a Flandres o primeiro agrupamento do Corpo Expedicionário Português (CEP), o qual se juntava à batalha ao lado das potências aliadas.

A maioria da população portuguesa da época era indiferente ou contrária a participação no conflito. Para os segmentos republicanos pró-intervenção, sobretudo aqueles reunidos em torno do Partido Democrático, a participação do país na guerra poderia funcionar como uma força nacionalizadora. Os intervencionistas acreditavam que uma mobilização nacional em função da guerra contra o inimigo externo, ajudaria na consolidação do regime republicano em todo o país, expandindo-o para além da esfera urbana. Tal interpretação parece ser dominante na historiografia portuguesa sobre a I República.

Os promotores da Atlântida apoiaram nas páginas da publicação a decisão do Governo republicano de intervenção de Portugal na Guerra. Neste contexto, os conteúdos da revista referentes ao conflito mundial corroboravam numa mensagem de apoio aos países aliados e à causa nacional com o envolvimento de Portugal no conflito. Muitas matérias assumiam um posicionamento patriótico, destacando-se especialmente o número vinte e cinco, de 1917. Este apresentava-se como uma edição organizada com fins de campanha patriótica, com artigos em português e francês.

As manifestações de apoio e defesa da união luso-brasileira ganhavam novos contornos nas páginas da revista. Enfatizava-se as iniciativas de apoio da elite da colónia portuguesa no Rio de Janeiro à pátria natal beligerante ${ }^{82}$ e celebrava-se a declaração de guerra por parte do Brasil à Alemanha ${ }^{83}$, em Outubro de 1917. É valido recordar, que em Abril do mesmo ano os Estados Unidos adentrava no cenário da Grande Guerra ao lado da Entente (Império Britânico, França e Império Russo).

\footnotetext{
81 Do lado intervencionista encontrava-se parte do Partido Socialista Português (PSP), o Partido Democrático (sob a liderança de Afonso Costa) e o Partido Evolucionista (comandado por António José de Almeida). Havia ainda setores da elite intelectual e artística republicana, reunidos em torno da revista Águia, que apoiavam a entrada de Portugal na guerra. Dentre os anti-intervencionistas estavam os monárquicos, os unionistas (liderados por Brito Camacho), os seguidores de Machado Santos e o restante do PSP (MENESES, Filipe Ribeiro de. In: ROSAS, F., ROLLO, Maria Fernanda (org.). História da Primeira República Portuguesa, 2010: 267-276).

${ }^{82}$ Atlântida, no 6, 1916: 604-605

${ }^{83}$ Atlântida, no 18, 1917: 493-496.
} 
Em artigo intitulado "O Brasil e a Guerra", João de Barros evocava todos os países latinos a "amar, admirar e festejar o Brasil ${ }^{84 "}$ pela sua entrada no conflito. Mais adiante, afirmava não pensar que a posição tomada pelo Governo republicano brasileiro fora somente determinada pela declaração de guerra da Alemanha aos Estados Unidos da América.

Aos olhos de Barros, mesmo considerando os interesses políticos, económicos e geográficos entre os dois países Americanos, o Brasil encontrava-se em beligerância com o Império Germânico, ainda que uma "beligerância de espíritos" desde que a Alemanha havia declarado guerra à Portugal. Tal apoio a Portugal podia ser observado na simpatia de toda a imprensa brasileira pela causa portuguesa, segundo apreciação do autor (Atlântida, no 25, 1917: 158).

Devemos considerar, tendo em vista as questões apresentadas por João de Barros, que após a instauração da República brasileira foram intensificadas as relações de aproximação com os Estados Unidos. O novo regime propiciava um melhor entendimento diplomático entre o Brasil e as outras repúblicas americanas. Demarcava-se o abandono do monarquismo europeísta, simbolizado pelos Bragança, e afirmava-se a adesão ao ideal republicano e liberal das Américas (BAGGIO, 2000: 3-4).

Esta tendência ganhou cores mais fortes na política externa estabelecida pelo Barão de Rio Branco, entre os anos de 1902 e 1912. O então Ministro das Relações Exteriores reconhecia a ascensão dos Estados Unidos da América no século que se iniciava, ao lado do crescente protagonismo do país na conjuntura internacional. Diante disto, adotou uma estratégia de ampliação das relações internacionais, visando um estreitamento dos vínculos com os EUA. Dessa forma, buscava-se uma gestão de equilíbrio entre o predomínio britânico e o norte-americano no Brasil ${ }^{85}$.

O projeto da revista em prol de uma união luso-brasileira ganhou visibilidade num contexto de instabilidade mundial, no qual as políticas de alianças eram consideradas positivas:

\footnotetext{
${ }^{84}$ Atlântida, no 25, 1917: 156-161.

${ }^{85}$ Do ponto de vista do debate intelectual sobre o pan-americanismo foi fundada a Revista Americana, publicada no Rio de Janeiro entre os anos de 1909 e 1919, cuja proposta era uma aproximação intelectual e política entre os países americanos. A revista foi um dos instrumentos de divulgação da política americanista exercida por Rio Branco (BAGGIO, Kátia Gerab, 2000: 1-2).
} 
"Parece que chegamos a um instante único na historia da Terra, em que se vão unir definitivamente, para uma aç̧ão de conjunto os grupos humanos que teem entre si afinidades e relações, que só unidas e amalgamadas poderão produzir o maximo da sua força e de seu explendor! (A Direção, Atlântida, nํ1, 1915: 94).

A conjuntura do pós-guerra e a então nova organização mundial influenciou na orientação da revista. Em 1919, a partir do trigésimo sétimo número, delineou-se uma segunda fase, com alterações na organização e no direcionamento do mensário. Além de João de Barros (diretor para Portugal) e João do Rio (para o Brasil), acrescentou-se uma direção em França, exercida pelo escritor brasileiro Graça Aranha. Registaram-se, ainda, mudanças no quadro gerencial da revista. Deixava de ser gerida por Pedro Bordalo Pinheiro ${ }^{86}$ e passava às mãos do jornalista português Nuno Simões (18941976) ${ }^{87}$, que assumia o cargo de diretor-gerente.

A publicação apresentou ainda novo subtítulo: “órgão do pensamento latino no Brasil e em Portugal". A partir disso, o periódico então franco-luso-brasileiro deixou de configurar-se como mensário e o mote era então promover a vitória do espírito latino e o triunfo da íntima união entre Portugal e Brasil nas suas raízes latinas. As características cosmopolitas e universalizantes da revista passaram a desempenhar um papel tão importante quanto o da promoção da amizade luso-brasileira (CONCEIÇÃO, 1997: 34-36).

Nessa fase, o quadro de colaborações ampliou-se e registaram-se contribuições de escritores franceses, italianos e espanhóis. Junto ao alargamento dos propósitos da Atlântida, verificou-se a fraca ou mesmo ausente contribuição brasileira na revista. Essa questão da reduzida participação de textos brasileiros no periódico foi identificada como ponto sensível da publicação. Tornou-se um fator de empecilho ao

\footnotetext{
${ }^{86}$ Sobrinho de Rafael Bordalo Pinheiro (1846-1905), importante caricaturista político-social português. 0 envolvimento da família Bordalo Pinheiro no projeto editorial da Atlântida parece ter sido significativo.

${ }^{87}$ Nascido em Vila Nova de Famalicão, Nuno Simões foi jornalista, advogado e economista. Destacou-se no republicanismo português, ocupando várias funções, tais como: Governador Civil de Vila Real, membro do Supremo Tribunal Administrativo, Deputado e Ministro do Comércio e das Comunicações em três governos da 1a Republica, entre 1921 e 1925. Segundo estudo de Arminda Ferreira (2005), O Luso-brasileirismo na perspectiva de Nuno Simões, foi um dos grandes defensores da causa lusobrasileira.
} 
cumprimento dos propósitos para os quais fora fundada, ou seja, promover um intercâmbio cultural que atendesse a um público luso-brasileiro (SARAIVA, 2004: 129).

Algumas explicações para esse facto podem ser deduzidas a partir das cartas enviadas por João do Rio a João de Barros. O escritor brasileiro, responsável por reunir as colaborações e tratar da distribuição da revista no Brasil, dentre outros afazeres atribuídos ao cargo de diretor, dava notícias do andamento dos trabalhos em carta remetida ao amigo em 13 de Fevereiro de $1916^{88}$. Tratava-se, portanto, da fase inicial da edição da Atlântida. João do Rio apresentava alguns dados da parte financeira e mencionava as dificuldades em reunir contribuições junto aos escritores brasileiros. Alguns trechos são bastante curiosos:

"Ao que parece, julgar q. eu não me interesso [...] collaborações. Sei de alguns cabalheiros como o Justino de Mondalvão a quem escreveste directamente. O Justino está perdido e com insistencia ? desde novembro. [...] as mulheres absorvem-no [...] O Alberto Oliveira ha trez mezes anda limando seus versos [...] E o Coelho Neto q. me prometteu um livro sem ter escripto uma linha d'elle, todo dia diz q. vae mandar.

Quanto aos rapazes q. me deviam escrever o mez - adiam sempre. Tenho aliás mandado ainda assim muita collaboração. E conto encher-te de trabalhos de modo a q. possas vir em Julho deixando os numeros até o fim do ano cheios de collaboração brasileira".

Para além dos pormenores, com pitadas de maledicência, utilizados pelo escritor para justificar os atrasos no envio de trabalhos, nota-se o empenho de João do Rio em contornar as dificuldades com promessas de conseguir angariar material para os próximos números. Na sessão "Cartas do Brasil" da Atlântida, nas quais assinava como João D’além, João do Rio mencionava ainda os problemas de comunicação que dificultavam o envio das matérias do Brasil. É interessante pensarmos na noção de tempo da época, quando os meios de vencer as distâncias eram restritos. Uma viagem marítima de Portugal a Brasil poderia levar cerca de um mês, agravada as condições no período da Guerra:

\footnotetext{
${ }^{88}$ Paulo Barreto, (N11/2716), Espólio João de Barros da Biblioteca Nacional de Portugal.
} 
"A dificuldade da navegação no momento será outrosim causa de que as informações que eu possa mandar daqui cheguem um tanto atrazadas ás terras luzitanas e estou certo tambem que depois da instalação da agencia Americana em Lisbôa, o que tão bom sucesso produziu aqui, o telegrafo precederá de muito as noticias por mim enviadas" (Atlântida, no 9, 1916: 872).

Em outra carta com data de Maio do mesmo ano, preocupado com a ideia de que Barros julgava-o pouco empenhado na promoção da revista, João do Rio reforçava o seu comprometimento com a publicação e revelava os problemas enfrentados. Dizia não ter conseguido ninguém para desempenhar a função de agente da Atlântida. Falava, ainda, do insucesso junto aos comerciantes, no que se referia ao recolhimento de anúncios e assinaturas. Mencionava que o público em geral considerava o preço do periódico avulso dispendioso e somado a esses factos havia os agravamentos causados por não ter amigos no poder nessa altura, como anteriormente quando idealizara o mensário: “... era preciso uma parte commercial violenta. Eu não a posso fazer agora como faria em 1908 - porque na epoca com o Calmon ${ }^{89}$ e o Nilo ${ }^{90}$ depois teriamos de cara o seu esforço e auxilio de mil ou duas mil libras. E agora não ha dinheiro, trata-se do imposto [...] e os amigos não estão no poder ${ }^{91 " \text {. }}$

Concluía com rasgos afetuosos à João de Barros e renovava os votos em solucionar os problemas:

"Não podes duvidar do meu carinho por ti. Cito-te em todos os jornaes, em todas as conferencias, em todos os lugares, a todos os amigos. Tenho a preocupação permanente do meu querido João. Não é mais amizade: é um escandalozo amor [...] Seriamente, achar crivel q. eu pense menos na Atlântida? A esperança porém não morre. [...] a ver se arranjo com os estados coisas. De um momento

\footnotetext{
${ }^{89}$ Nesse caso, João do Rio referia-se, provavelmente, a Miguel Calmon Du Pin e Almeida (1879-1935). Este foi engenheiro e político brasileiro, que de 1906 a 1909 desempenhou a função de Ministro e Secretário de Estado dos Negócios da Indústria, Viação e Obras Públicas do Governo Afonso Pena e depois de Nilo Peçanha.

90 João do Rio referia-se a Nilo Procópio Peçanha (1867-1924). Este ocupou o cargo de Presidente da República após o falecimento de Afonso Pena, em 14 de junho de 1909 e governou até 15 de novembro de 1910.

91 Paulo Barreto, 30 de maio de 1916 (N11/2717), Espólio João de Barros da Biblioteca Nacional de Portugal.
} 
para outro ellas vêem. Espero o Dantas ministro e uma vaga promessa de Minas Geraes".

No entanto, os entraves referentes a publicação da revista persistiram. As mudanças de direcionamento na segunda fase em 1919, embasada na matriz latina e, portanto, aberta a novas colaborações visavam produzir condições para se dar continuidade ao periódico:

“... Com efeito, a aproximação luso-brasileira, e por cuja realisação tem combatido para cuja defesa ela se fundou só encontrará a sua completa efectivação quando baseada no mesmo e ardente amor pela alma latina que vive e palpita nas duas Pátrias irmãs, filhas de uma só raça, aventurosa, leal e progressiva" (Atlântida, no 37, 1919: 3).

Em carta enviada a João de Barros, Graça Aranha, então diretor na França, prestava contas dos gastos com as colaborações que haveriam de enriquecer o conteúdo da revista, falava ainda da sua satisfação com o último número e deixava uma nota sobre a impaciência dos financiadores da publicação: "Fique certo de que me esforçarei pela Atlântida com a maior dedicação. E os seus terriveis capitalistas [...] que tenham confiança e animo para o que acontecer ... ${ }^{92 \prime \prime}$.

Foram ainda editados 12 números nesse período. Entretanto, a publicação não resistiu às dificuldades e desafios do pós-guerra e, provavelmente, à saída de João de Barros do projeto, anunciada no quadragésimo sexto e sétimo números (edição dupla).

Os traços da lusobrasilidade da revista aparecem nas formas de representar Brasil e Portugal, na valorização do emigrante português, na herança cultural partilhada, com destaque para o passado histórico em comum e a língua. Esses elementos foram utilizados como argumento para mobilizar o culto das duas-mãespátrias no Brasil (PAIVA, 2001: 191). Essa questão revela-se, sobretudo, no momento em que a Atlântida abriu espaço para as discussões em torno da ideia de uma Confederação Luso-Brasileira, defendida por intelectuais e políticos da época. É sobre essa proposta confederativa que trataremos a seguir.

\footnotetext{
${ }^{92}$ Graça Aranha; 1868-1931, (N11/111); Paris, 1 de Junho de 1919. Espólio João de Barros da Biblioteca Nacional de Portugal.
} 


\section{II.2. Uma Confederação Luso-brasileira: entre o eloquente e o polémico}

Um tema abordado na revista, o qual ao nosso ver merece destaque no tocante à aproximação luso-brasileira foi a discussão em torno de se criar uma Confederação entre os dois países. Achamos pertinente, em função da riqueza das representações elaboradas, expor algumas considerações acerca desta ideia. Tal proposta configurouse por meio de formulações teóricas, expressas por grupos de intelectuais nas duas margens do Atlântico.

Nas páginas da revista, as primeiras considerações acerca da ideia confederativa foram apresentadas pelo diplomata português Bettencourt Rodrigues $(1854-1933)^{93}$. Esta questão foi alvo de debate em alguns números da Atlântida, sobretudo no ano de 1917. Criou-se uma sessão especial denominada Inquéritos, dedicada a colher as opiniões da intelectualidade portuguesa e brasileira acerca do tema. A mesma foi inaugurada pela entrevista realizada por João de Barros à Rodrigues, intitulada “A Confederação Luso-Brasileira - será possível uma nova e grande Lusitania?" (Atlântida, no 20, 1917: 659-673).

Dentre outras questões, Rodrigues atribuiu ao escritor brasileiro Sílvio Romero (1851-1914) as bases para tal projeto. A conveniência de fortalecer no Brasil o elemento português foi proposta como tese central numa conferência, realizada por Romero, em 1902, no Real Gabinete Português de Leitura do Rio de Janeiro. Para o escritor $^{94}$, as características essenciais da nacionalidade brasileira transplantadas pelo

\footnotetext{
93 António Maria Bettencourt Rodrigues, médico alienista, doutorado por Paris, estabeleceu-se no Brasil entre os anos de 1892 a 1913, por ter sofrido perseguição política devido as suas convicções republicanas. Ao retornar a Portugal foi nomeado Embaixador em Paris, tendo sido demitido devido à revolução de 15 de Maio de 1915. Próximo a Sidónio Pais, apoiou o golpe de Dezembro de 1917, recuperando o seu cargo em Paris. Regressou a Portugal após a morte de Sidónio, tendo estado antes na delegação portuguesa à Conferência de Paz de Paris.

${ }^{94}$ Como pensador da sua época, Sílvio Romero sofreu influência das principais correntes teóricas da segunda metade do século XIX, incorporando pressupostos do positivismo evolucionista social de Herbert Spencer e das teorias raciais (tais como o Darwinismo Social) do período. Havia, portanto, uma tendência em buscar leis gerais que pudessem explicar a evolução das sociedades. No que concerne a questão racial, apresentaram-se teorias raciais no século XIX com estatuto de discurso científico, que buscavam explicar as diferenças entre os grupos humanos. Desta forma, foram legitimadoras do imperialismo europeu, estabelecendo uma hierarquização da humanidade, na qual a "raça" branca era considerada o símbolo maior do progresso e da civilização (Conf.: RODRIGUEZ, Ricardo Vélez, 1994).
} 
elemento cultural português encontravam-se ameaçadas. Havia uma preocupação com os crescentes núcleos imigratórios de várias proveniências, sobretudo os alemães e italianos, e a imposição de novas referências culturais à sociedade brasileira:

"Se, pois, meus senhores, nós os brasileiros quizermos continuar a ter essa feição, a manter na história esse caracter; se não nos sentirmos tentados a mudar de aspecto e transformar a nossa nacionalidade em teuto-americana, anglo-brasileira, italo-brasilica ou qualquer outra coisa que até a lingua sente dificuldade em articular, qualquer outra coisa ao sabor d'essas vaidosas e rapaces potencias empenhadas na tarefa de ameaçar, de metter medo com avassallamentos, divisões e conquistas ... Dos portuguezes não temos só a imitar o exemplo: é mister unirmo-nos a elles, chamal-os o mais possível a collaborar comnosco" (ROMERO, 1902: 9-10).

Mais adiante, argumentava Romero acerca da solidez da tradição cultural partilhada ("a unidade da língua, do direito, da religião, dos ideais politicos e sociais") entre os dois países, como fator unificador. O autor defendia um fortalecimento das relações bilaterais entre Portugal e Brasil, em meio a uma conjuntura de construção de ideologias transnacionais em disputa na época. Diante das aspirações imperialistas pan-germánicas, pan-eslava e pan-americana era necessário promover-se a união "do grande grupo étnico luso-brasileiro" (LEAL, 2009/2010: 6).

Segundo essa visão, todos os esforços deveriam ser mobilizados em busca da aproximação entre os dois países. Romero enfatizava, ainda, a importância de se estimular a imigração portuguesa para o Brasil, pois a mesma havia sido suplantada por outros grupos imigratórios entre os finais do XIX e início do século XX (ROMERO, idem: 29).

Em Portugal tal aliança teria sido aventada pela primeira vez numa reunião da Academia das Ciências de Lisboa, em 1908, pelo escritor e diplomata Coelho de Carvalho (1855-1934), então presidente da instituição. Era já pensada enquanto configuração de um sistema político. No ano seguinte, foi proposto pelo professor universitário e ensaísta português Zófimo Consiglieri Pedroso (1851-1910) à Sociedade de Geografia de Lisboa um Acordo Luso-brasileiro. O acordo fundamentava-se nos 
laços de sangue, de raça e em interesses e aspirações comuns entre os dois povos e sugeria como formas de efetivação:

... a realização de congressos periódicos luso-brasileiros, alternadamente em Lisboa e no Rio, tratados de comércio e de arbitragem, linha de navegação, entrepostos nas capitais dos dois países, unificação ou pelo menos, harmonização da legislação civil e comercial dos dois países, equivalência de diplomas scientíficos... (RODRIGUES, Atlântida, no 20, 1917: 660).

Apesar de alguns ensaios de aproximação intelectual, a proposta de Consiglieri Pedroso não foi levada adiante, tendo em vista a morte prematura do seu criador, no entanto o tema da união luso-brasileira estaria sempre presente de alguma maneira, segundo Rodrigues. A discussão viria a ser retomada pelo diplomata português Coelho de Carvalho, em 1916, numa homenagem prestada pela Academia das Ciências de Lisboa ao poeta brasileiro Olavo Bilac. Nas palavras de Carvalho: “... esta aliança política das duas pátrias, seria a única profícua e perdurável, porque, antes de existir em tratados já a impõem a identidade da raça e a unidade da língua" (idem: 663).

João de Barros propôs a seguinte questão a Rodrigues; quais seriam as vantagens que adviriam para os dois países de uma confederação? Segundo o diplomata, a ideia de uma confederação, diferentemente dum simples acordo ou aliança, impor-se-ia a atenção de brasileiros e portugueses. Sobretudo, em meio às disputas geradas num contexto de guerra.

As vantagens eram inegáveis em vários aspectos, defendia o diplomata. Do ponto de vista geográfico, verificava-se a convergência de inúmeras linhas de navegação. O Brasil numa extensa margem da América austral e quase em frente, na costa africana, encontrava-se Angola, então colónia portuguesa. Entre as duas margens o Atlântico Sul, como um mar lusitano. Havia ainda o arquipélago de Cabo Verde numa zona de navegação comum ao Brasil e à África Ocidental. Mais ao Norte, como pontos de escala, os Açôres e a Madeira. Para completar esse quadro, como vasto entreposto comercial dos produtos de Portugal e Brasil encontrava-se o amplo porto de Lisboa (ibidem: 670-671). Conforme mapa a seguir: 


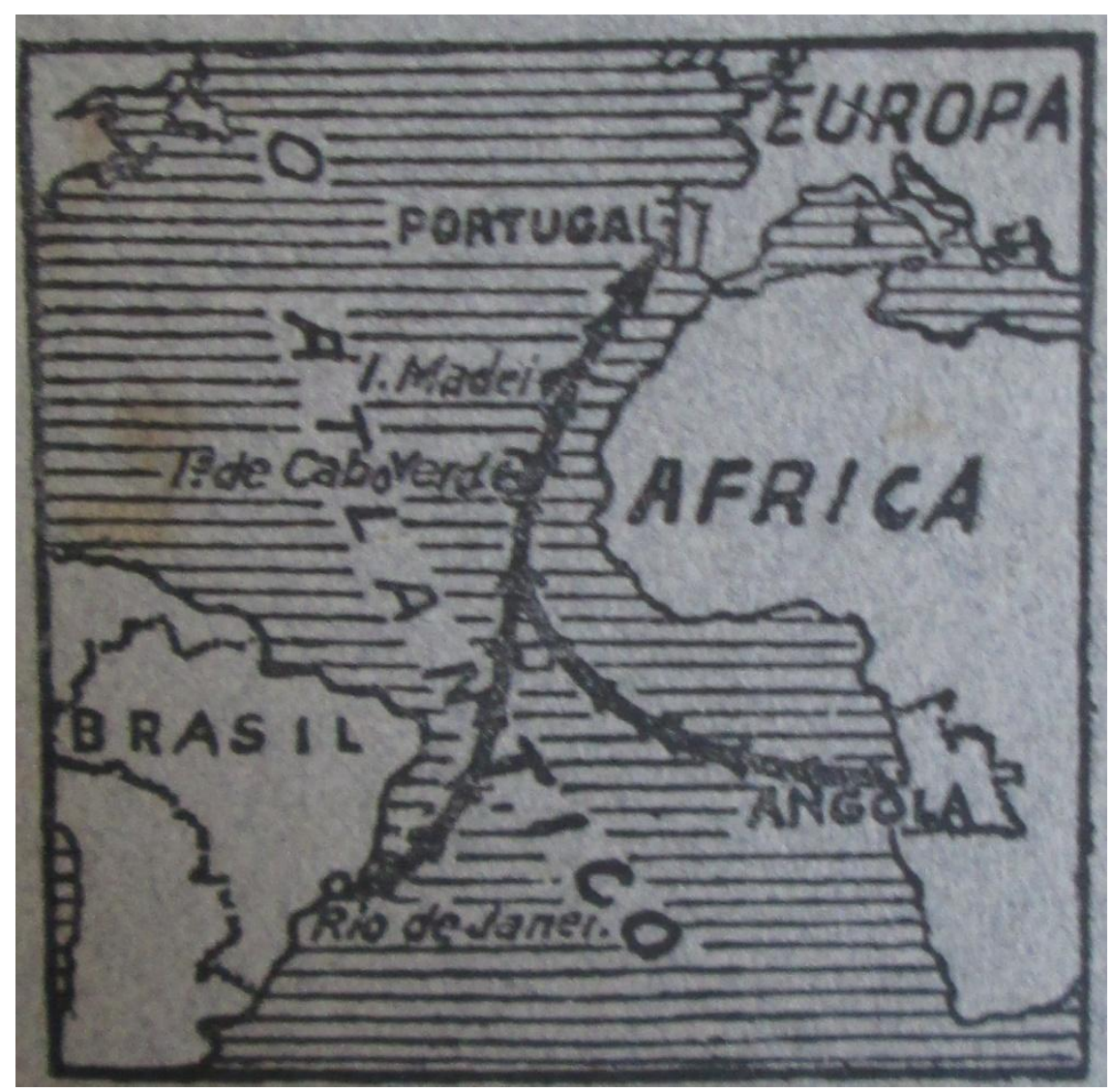

RODRIGUES, Bettencourt. Uma Confederação Luso-Brasileira. Lisboa: Livraria Clássica Editora, 1923.

Rodrigues ainda argumentava, que diante das incertezas da época era necessário zelar pelo futuro da "raça portuguesa". Havia muitas dúvidas quanto ao porvir reservado às pequenas nacionalidades. Nesse sentido, diante das disputas políticas mundiais da época, em que se adotavam princípios ideológicos como "A América para os Americanos", o pan-eslavismo da Rússia, o pan-germanismo da Alemanha e o pan-iberismo da Espanha dever-se-ia pensar no lusitanismo. Os portugueses e os brasileiros apresentavam todas as características comuns para um agrupamento étnico, segundo essa visão:

"Ligados no passado por glorias e tradições communs, porque não hão-de portuguezes e brasileiros, unindo os seus destinos, constituir uma nova e grande Lusitania? Portugal seria, na Europa, o centro de irradiação, a fons gentium da raça lusitana, e o Brasil, onde o seu esforço e o seu genio tão intensamente se vivificam e florescem, seria, na America, o seu vasto e fecundo campo de expansão..." (idem, ibidem: 672). 
Numa outra matéria, promovida pela secção Inquérito da revista, B. Rodrigues tecia comentários sobre a viabilidade e vantagens do projeto confederativo. Num primeiro momento, para que a Confederação Luso-Brasileira pudesse ser levada adiante era necessário que a elite intelectual dos dois países se pronunciasse. Ao lado disso, era preciso um arranjo internacional e constitucional, respaldado por uma estrutura jurídica que pudesse viabilizar tal unificação política (Atlântida, no 22, 1917: 841-847).

Avaliava os proveitos comerciais e económicos, tendo em vista a produção do Brasil e das colónias africanas; "Portugal e Brasil unidos, teriam de futuro, no mercado mundial, o indisputável monopólio de todos os variadíssimos produtos dessas duas imensas e fertilíssimas regiões" (idem: 841).

Em carta a B. Rodrigues, Magalhães Lima (1851-1928) tratava o tema da confederação no contexto da Grande Guerra e suas implicações no cenário mundial. Na visão deste jornalista, político republicano e escritor português, a união entre os povos por afinidades culturais constituía-se como um importante elemento de força contra o autoritarismo, que havia desencadeado o conflito. Concebia a forma federativa como uma solução para o futuro:

"Tambêm eu, antes da guerra, pensara numa aliança. Mas os factos ocorridos, nêstes últimos anos, trouxeram-me a convicção de que a solução para o problema do futuro há-de residir na forma federativa. O Atlântico será o continuador do Mediterrâneo. É para êle que devemos voltar as nossas vistas. Mare nostrum chamavam os latinos ao Mediterrâneo. Mare nostrum, chamaremos nós, brasileiros e portugueses, ao Atlântico" (ibid.: 846).

É interessante observar, como em várias matérias da revista sugere-se uma naturalização da geografia, ao se veicular uma imagem de destino atlântico de Portugal, tendo em vista as suas posições geográficas. Alimenta-se a visão de que o Atlântico pertencia ao país, de facto e de direito. Dessa forma, dá-se a naturalização de um projeto político, o da realização de uma unidade política luso-brasileira, como parte de um grande Império Colonial Português, valendo-se da imagem poética do mar e respaldada na ideia da vocação atlântica portuguesa (PAIVA, 2001:192). 
Alberto de Oliveira, então Cônsul Geral de Portugal no Rio de Janeiro, enviou também a sua opinião acerca de uma confederação entre Portugal e Brasil. Falava sobre a força de uma Lusitânia, configurada no agrupamento entre os povos lusobrasileiros em comparação com a Ibéria. Ambas eram formadas por povos com afinidades, no entanto, na Ibéria as nações diferenciaram-se na impossibilidade de se projetar um destino comum. Segundo Oliveira, no caso da Lusitânia, representada pela união entre portugueses e brasileiros, havia a possibilidade de se construir um futuro comum, fundamentado no passado e no presente dessas relações:

"De um lado Portugal garantindo ao Brasil logar e voz no concêrto europeu, oferecendo-lhe, nos seus portos do continente e das colónias abrigo e ponto de apoio às suas esquadras de guerra e de comércio; do outro lado o Brasil abrindo mercados imensos aos nossos produtos, expansão ilimitada à nossa raça e à nossa língua..." (Atlântida, no 23, 1917: 965).

Na mesma secção da Atlântida, o poeta e ensaísta português Jaime de Magalhães Lima (1859-1936) ${ }^{95}$ afirmava que dever-se-ia entender a confederação lusobrasileira como fruto da psicologia dum povo, produzida ao longo de várias gerações. Nessa perspectiva, não era o pensamento político que se impunha, mas o resultado das afinidades culturais. As iniciativas em torno do projeto fortaleceram-se dado o contexto de guerra, no entanto, tal proximidade fora sempre um "facto natural", segundo o escritor (Atlântida, № 26, 1917: 261-264).

Na sequência ao inquérito, o então oficial da Marinha portuguesa 10 tenente Nunes Ribeiro, apresentou uma análise do potencial de uma Confederação LusoBrasileira do ponto de vista económico e militar. Apoiava-se em algumas teorias (Mahan, Callwell e Bonamico ${ }^{96}$ ) para dar suporte ao seu argumento de defesa das condições estratégicas privilegiadas ao se promover tal Confederação, sobretudo na perspectiva militar. Pensava ainda na aliança entre Brasil, Portugal e Angola, dadas as condições de administração autónoma vigentes. As outras colónias portuguesas não gozavam de self administration (idem: 265).

\footnotetext{
95 Jaime de Magalhães Lima era monárquico, católico e tolstoiniano. Irmão do jornalista, político e escritor português Sebastião de Magalhães Lima, citado anteriormente.

${ }^{96}$ Autores especializados em estudos de estratégias militares de defesa marítima.
} 
O tenente destacava três questões fundamentais que exteriorizavam a expansão económica: a emigração, a exportação e o tráfico (transporte marítimo). Quanto à emigração fez a seguinte consideração:

"A emigração, que é o fenómeno mais antigo da expansão, originou, quási por si só, as condições necessárias para a sólida realização duma confederação luso-brasileira. A emigração permitiu nivelar as funções transcendentes do génio, da invenção, e da fortuna nos cometimentos dos povos dos dois países e poder de realização ..." (ibid.: 265).

Desenvolveu também considerações acerca da deficiente navegação entre os dois países, questão que cerceava as vantagens da exportação, tendo em vista a dependência do transporte marítimo estrangeiro. Esta limitação constituía-se como um problema que demandava solução (idem, ibid.: 265).

Ribeiro observou, ainda, as vantagens militares envolvidas na promoção de um sistema confederativo. Tal medida garantiria a organização de um considerável potencial militar, dada a percentagem de mobilização que permitiriam as regras sobre a população das três regiões envolvidas: a Península Ibérica, a América do Sul e o Oeste Africano. A organização militar marítima viria a complementar o potencial militar e permitiria, por sua vez, o domínio do mar no Atlântico Sul (Atlântida, no 26, 1917: 268).

Essas foram as opiniões esboçadas entre as personalidades portuguesas que colaboraram na revista. Bettencourt Rodrigues lançou um livro ${ }^{97}$, em 1923, sobre o tema da confederação. Nessa obra recuperou as matérias da Atlântida, acrescidas de novos conteúdos e discussões. Do lado português, o autor indicou como também favoráveis ao projeto; o Coronel João de Almeida, o escritor Teixeira de Queiroz, o arqueólogo e escritor Ricardo Severo, o historiador e político Anselmo Braamcamp Freire, o então deputado Afonso de Mello e o escritor Julio Dantas.

O Coronel Almeida (1873-1953?) afirmava que para a realização de tão nobre objetivo, fazia-se necessário que os portugueses atendessem aos interesses brasileiros, garantindo-Ihes maiores vantagens do que os outros países. Ao Brasil, caberia o dever

\footnotetext{
${ }^{97}$ Uma Confederação Luso-Brasileira: factos, opiniões e alvitres. Lisboa: Livraria Clássica Editora, 1923.
} 
da reciprocidade colaborando com Portugal e auxiliando-o nas relações com as colónias (RODRIGUES, 1923: 119).

Teixeira de Queiroz (1848-1919) mostrou-se entusiasmado com a ideia de uma Confederação Luso-brasileira, mas um tanto reticente sobre a sua concretização. Sendo assim, considerava o escritor que a construção de um grande império com a raça portuguesa "será um sonho, porque o egoismo dos homens o não deixará realisar; mas é um sonho que embriaga e exalta os corações velhos como o meu, cheio de scepticismos, de experiências desoladoras ..." (idem: 120).

Ricardo Severo (1869-1940) ressaltava as vantagens de uma confederação do ponto de vista geo-político. Segundo o arqueólogo, o Brasil seria favorecido ao buscar uma política de expansão via Atlântico, em função da sua posição geográfica. Uma união com Portugal facilitaria tal processo. Caso isso não se efetivasse, o país teria que se aliar à América do Norte, tendo em vista a configuração expansionista da época. No entanto, a formação de um grupo luso-brasileiro constituiria "pela sua vastidão territorial, pela natureza intima da sua alliança, pela nobre rigidez do seu caracter, uma potencia de primeira grandeza, cuja influencia na politica mundial seria basilar e decisiva" (ibidem: 122).

O escritor Julio Dantas (1876-1962) ponderava o facto de que a política internacional do período estava sendo feita por meio do agrupamento das nações, sobretudo daquelas de mesma origem. Dentro dessa perspectiva, defendia a aliança entre Portugal e Brasil: "Portugal, com as suas colonias; o Brasil, com seu immenso território, são dois grandes corpos, mas que ninguem procure separal-os na sua explendida marcha para a civilisação..." (idem, ibid.: 128-129).

Ao lado de Sílvio Romero, outros brasileiros como; Graça Aranha, Domício da Gama, Medeiros e Albuquerque, Pinto da Rocha, Spencer Vampré, Alberto Seabra e Noé de Azevedo, dentre outros, emitiram opiniões favoráveis acerca de uma federação lusobrasileira. 
O escritor Graça Aranha, diretor da Atlântida em França (1919), escreveu artigo ${ }^{98}$ à revista no qual ressaltou as vantagens de uma união política entre os dois países: "Unido a Portugal, o Brasil se tornaria uma nação europeia realizando a fusão do Oriente e do Ocidente sob um só espírito nacional, que seria português como para outras regiões é inglês ou francês" (Atlântida, no 37, 1919: 10). Da perspectiva lusa, haveria ganhos políticos e uma renovação do espírito português por influência da mocidade americana brasileira. Com a unidade findariam as barreiras fiscais entre os dois países e, dessa forma, Lisboa transformar-se-ia na grande cidade europeia base do comércio brasileiro, segundo o autor.

O escritor mencionava ainda os ganhos do ponto de vista económico que poderiam advir dessa união. Segundo $\operatorname{Aranha}^{99}$, tal potencial fora vislumbrado pelos alemães, os quais ambicionaram apossarem-se do Sul do Brasil e das colónias africanas portuguesas. Planeavam, assim, canalizar para Hamburgo os produtos brasileiros e angolanos. No caso de uma confederação luso-brasileira, não haveria mais concorrência entre os produtos comuns ao Brasil e às colónias africanas, mas uma colaboração proveitosa (idem: 11).

Estes rumores em torno de um plano ou "perigo" alemão relativos ao território Sul-brasileiro devem ter contribuído para as formulações que defendiam uma aliança com Portugal. Aranha, em prefácio do livro O Plano Pangermanista Desmascarado ${ }^{100}$, mencionou a pouca atenção conferida pelo Governo brasileiro à ameaça alemã no país (CHÉRADAME, 1917: XVIII-XIX).

\footnotetext{
98 O artigo intitulado A Nação foi, posteriormente, publicado no livro de Graça Aranha; A Estética da Vida (1921).

${ }_{99}$ Alguns anos mais tarde, Graça Aranha mudará o seu posicionamento acerca das relações entre Brasil e Portugal, aproximando-se do movimento modernista brasileiro que buscava um rompimento com o passado colonial. O escritor defendeu a seguinte visão em conferência, realizada em 1924, na Academia Brasileira de Letras:"... Em vez de tendermos para a unidade literária com Portugal, alarguemos a separação. Não é para perpetuar a vassalagem a Herculano, a Garrett e a Camillo, como foi proclamado no nascer a Academia, que nos reunimos. Não somos a câmara mortuaria de Portugal. Já é demais este peso da tradição portugueza, com que se procura atrophiar, esmagar a nossa literatura. É tempo de sacudirmos todos os jugos e firmarmos definitivamente a nossa emancipação espiritual. A cópia servil dos motivos artísticos ou literários europeus, exóticos, nos desnacionaliza...". In: Espírito Moderno. São Paulo: Cia. Gráfico Editora Monteiro Lobato, 1925, pp. 42-43.

${ }^{100}$ CHÉRADAME, André. O Plano Pangermanista Desmascarado. Rio de Janeiro/Paris: Livraria Garnier, 1917.
} 
Conforme referido por Sílvio Romero em texto de 1902, o autor chamava a atenção para o "amolecimento da argamassa nacional" pela sutil invasão desse grupo estrangeiro. A aglomeração das massas alemãs no território brasileiro, a não assimilação por parte do elemento germânico da cultura brasileira, a persistência do idioma alemão que se impusera até em atos das câmaras municipais e medidas administrativas configuravam-se num movimento de desnacionalização aos olhos do escritor e de outras personalidades do mundo letrado da época (idem: XIX).

Com a I Guerra revelaram-se as intenções pan-germanistas de apossar-se do Estado do Rio Grande do Sul e outras regiões da América austral ${ }^{101}$. A acusação de expansionismo germanista foi difundida em muitos círculos brasileiros. Segundo Márcio de Oliveira, a acusação era crível, porém genérica. No contexto do neocolonialismo, vigente ao longo do século XIX, todas as nações europeias ordenavam sua política externa pela lógica imperial. Alguns autores consideraram relativos os interesses coloniais alemães na América do Sul. Tratava-se de um perigo possível, porém improvável, tendo em vista as dificuldades militares envolvidas numa iniciativa de tamanha envergadura (2012: 181).

No entanto, as denúncias sobre a não integração das comunidades alemãs ou concernentes aos interesses expansionistas do Império germânico possuíam os seus fundamentos. Eram as mesmas alimentadas pela Lei Delbruck (1913), que garantia a nacionalidade alemã a todos os descendentes nascidos fora da Alemanha, assim como, pela atuação da Liga Pangermânica (OLIVEIRA, idem: 181).

O programa dessa Liga contrapunha-se ao ideário integracionista das elites brasileiras do período. Embora a organização negasse o desejo de se constituir um "Estado dentro do Estado brasileiro", no seu programa afirmava que o "primeiro objetivo apresentado nos estatutos diz respeito à união de todos os alemães e seus descendentes em todo o mundo, no interior de uma grande comunidade nacional, cuja maior garantia é a preservação da língua, da raça, da índole, dos costumes alemães".

\footnotetext{
${ }^{101}$ Segundo Tannenberg (Gross-Deutschland, 1911), as ambições alemães na América do Sul consistiam em anexar ao Império germânico; o Rio Grande do Sul, a Argentina, o Paraguai e o Chile. In: CHÉRADAME, op. cit., pp. XXXIII-XXXIV.
} 
Ao lado disso, descartava qualquer possibilidade de assimilação das culturas locais (SEYFERTH, apud Oliveira, ibidem: 181).

A partir dessas considerações, podemos melhor situar os discursos favoráveis a uma confederação luso-brasileira como forma de garantir maior proteção aos territórios e culturas de ambos os países. O escritor e diplomata Domício da Gama (1862-1925) chegou a inscrever a união política luso-brasileira como um dos objetivos do seu programa a ser cumprido enquanto Ministro dos Negócios Estrangeiros do Brasil, em 1918. Acreditava que o Governo português, na altura Sidónio Pais, era também favorável ao projeto, por isso as dificuldades seriam facilmente ultrapassadas (RODRIGUES, 1923: 140).

“[...] Se tempo houve em que de Portugal se governou o Brasil e do Brasil se governou Portugal, hoje essa proeza seria infinitamente mais facil [...]" (idem: 143). Essas foram as palavras utilizadas pelo escritor e político Medeiros de Albuquerque (1867-1934), em artigo publicado no Jornal Estado de São Paulo em 1919, para conjeturar acerca de uma Confederação entre os dois países. O escritor chegou a propor um projeto de Constituição para o sistema político.

Segundo o autor, o modelo político seria inspirado na Áustria-Hungria. Para além da alternância dos presidentes a cada ano, haveria um Conselho de Estado. $\mathrm{O}$ mesmo, constituído por brasileiros e portugueses, seria consultado acerca de todos os negócios internacionais. As medidas externas teriam ainda de serem aprovadas pelos Senados dos dois países (ibidem: 146-147).

O escritor e magistrado Pinto da Rocha (1864-1930) pronunciou-se a respeito da realização de uma confederação luso-brasileira e disse não haver obstáculos instransponíveis para tal projeto. Sendo assim, as distâncias do mar que separam os países seriam contornadas pelos então meios de comunicação modernos, com destaque para o telégrafo. O ajustamento das legislações, apesar da diversidade, também seria viável. Assinalava, inclusive, as proximidades entre as Constituições portuguesa e brasileira da época, ponto esse que favoreceria os arranjos legislativos (RODRIGUES, idem, ibid.: 150). 
Em conferência proferida em 1922, no Instituto Histórico de São Paulo, o jurista Spencer Vampré (1888-1964) defendeu acaloradamente a união entre Brasil e Portugal:

"Imaginemos o Brasil e Portugal unidos, nas mesmas tendencias de paz, de justiça e de ordem internacional, a estender sobre o Atlantico os seus navios pejados de productos industriaes e agricolas, e as suas bandeiras confederadas tremularem simultaneamente em todos os mares - desde as rendilhadas costas do mar do Norte até as planicies infinitas do Oceano Pacifico; desde o mar das Indias, povoado outr'ora de mysterios, até oceanos polares, reflectindo nostalgicamente a brancura das suas neves eternas" (RODRIGUES, 1923: 152-153).

A partir dessas considerações, o autor remeteu ao aspecto da defesa das nações perante a ordem mundial. Nesse contexto, o pan-lusitanismo expresso na aliança entre Portugal, suas colónias e o Brasil, deveria funcionar como uma barreira de justiça e de poderio mercantil e militar contra quaisquer avanço de outros povos (RODRIGUES, idem: 154-155).

Corroborando as opiniões favoráveis em torno de uma união confederativa, o médico e sociólogo Alberto Seabra (1872-1934) considerava tal iniciativa como "o primeiro germen das instituições ibero-americanas". Alertava ainda para a situação das colónias portuguesas, cobiçadas por outros Estados. Uma política confederativa poderia favorecer uma maior segurança em relação às colónias lusas e uma confluência dos interesses do Brasil e de Portugal no Atlântico Sul (RODRIGUES, ibid.: 156-157).

No Sul do Brasil, também registaram-se ecos de defesa da proposta confederativa. Dom Duarte Velloso, em conferência realizada no Grémio Luiz de Camões de Curitiba, em 1918, defendia a confederação luso-brasileira, tendo em vista uma política de expansão do Brasil em meio às disputas dos países em guerra. Nesse contexto, destacava a posição geográfica privilegiada de Portugal e o seu então vastíssimo Império Colonial. Ressaltava, ainda, o facto dos portugueses no Brasil representarem o maior número de estrangeiros. "Cada colonia local quer primar pela 
grandeza do seu edificio; cada Lyceu pela riqueza da bibliotheca; cada Gymnasio pela difusão e variedade da instrucção" (1918: 21).

O autor conjeturava acerca do final da Guerra e o que faria o Brasil após o conflito mundial. Teria que buscar mercados para os seus produtos e nesse contexto seria vantajosa a Confederação Luso-Brasileira. Dentro de um acordo confederativo, o Brasil poderia armazenar os seus produtos no porto de Lisboa e depois distribuir para diversos países da Europa:

"A Confederação Luso-Brasileira, é portanto capaz de fazer dos dois povos irmãos os dois paizes mais grandiosos que poderão impor aos outros o que hoje não poderão fazer separados. Sem quebra alguma de autonomia política, Portugal e Brasil, que já hoje se entendem como irmãos, iniciarão uma nova phase na historia da Humanidade..." (idem: 32).

O advogado brasileiro Cavalcanti Melo publicou livro em $1919^{102}$, no qual apresentava um esboço jurídico que estabelecia as bases de governabilidade de uma Confederação entre as Repúblicas do Brasil e de Portugal. Para o autor, essa união poderia garantir o desenvolvimento económico, territorial, a densidade populacional, o aumento da riqueza e da segurança aos Estados envolvidos.

Quanto à conceção formal de um sistema confederativo luso-brasileiro, Cavalcanti descreveu o seguinte modelo: lei estrutural, forma de governo, competência do governo e formato do poder executivo.

Segundo tais diretrizes, para garantir a integridade das soberanias das Repúblicas, estruturalmente a confederação seria regulamentada por meio de um Tratado Internacional celebrado entre Estados soberanos. Haveria um governo central formado por uma delegação diplomática ou Assembleia, em que cada Estado teria os seus representantes. O mesmo seria responsável pela gerência dos negócios comuns, constituído por delegações brasileira e portuguesa. Caberia ainda a esse poder central ouvir o governo dos dois países antes de executar as suas deliberações. O poder executivo dessa organização política seria constituído alternadamente pelo poder

${ }^{102}$ A Confederação Luso-Brasileira: Esboço de construção jurídica. Funchal: Tipografia do "Diário de Notícias", 1919. 
executivo de cada Estado Confederado ou seria formado por uma comissão mista dos representantes de ambas as nações eleita pela delegação diplomática ou Assembleia (1919: 49).

O advogado apontou dentre os fins da confederação luso-brasileira, para além da confraternização plena entre os povos de ambas as nações, o auxílio mútuo em situações de guerra externa. Citou ainda a ampliação do mercado de consumo livre de impostos, o direito de exercício das profissões liberais e à livre costeagem em ambos os territórios confederados. Acenou também para a ideia de uma equiparação de um padrão monetário, a alternância da sede do governo central, ora em Lisboa, ora no Rio de Janeiro, dentre outras questões (idem: 50).

Conforme mencionado anteriormente, Medeiros e Albuquerque também deixou contributo acerca de aspectos da governabilidade de uma confederação lusobrasileira. Estabeleceu um esboço de constituição para o sistema político, com alguns pontos comuns ao Tratado Internacional elaborado por Cavalcanti. Citaremos, a seguir, alguns artigos propostos na constituição:

"Parag. único - Fica entendido que cada uma das duas nações confederadas guarda, inteira, a mais absoluta independencia em tudo o que concerne as suas organisações interiores, podendo alteral-as como Ihe parecer; art. 3o. - Considerar-se-há presidente da Confederação, alternadamente, cada anno, o presidente de uma das duas republicas; Parag. único - Ao prezidente da Confederação competem, além dos deveres de prezidente da nação de que é chefe, as decizões sobre os negocios comuns a Confederação; Art. 6‥ - A gestão dos negocios coloniais se fará por meio de uma junta de quatro membros, dois eleitos por cada um dos senados; Parag. 2ㅇ Em cazo de guerra, o comando supremo das forças cabe a um generalissimo eleito pelo Estado Maior Confederado. Sua nomeação precisará ser aprovada pelos dois senados; Art. 9o - As despezas e as receitas dos serviços comuns as duas unidades da Confederação, serão por igual repartidas entre ellas" (MEDEIROS E ALBUQUERQUE, 1922: 274-276).

Medeiros e Albuquerque considerava os possíveis ganhos que ambos os países teriam, caso o regime confederativo fosse aprovado de acordo com essa legislação. Do 
lado português, havia todo o mercado comercial que se abriria, o qual poderia the garantir prosperidade. A propriedade das colónias seria dividida, mas essa divisão poderia significar uma posse mais real dos domínios coloniais: "Portugal é uma nação pequena e o Brazil uma nação grande e fraca; a Confederação Luzo-Brazileira seria uma grande e forte nação" (idem: 276-277). Do lado brasileiro, afirmava o autor, ganhar-se-ia um domínio colonial. O Brasil passaria a ser uma potência mundial, com ramificações em várias partes do mundo (ibidem: 277).

Não deixa de ser curioso o facto de que tenha partido de duas personalidades brasileiras os escritos que deram formato de governabilidade à proposta confederativa. Conforme já referido, havia um movimento nacionalista no contexto brasileiro com vertente lusófoba, o qual fazia por desacreditar qualquer iniciativa que promovesse uma aproximação entre Brasil e Portugal, sobretudo uma proposta de união política entre os dois países.

Segundo Cavalcanti, diferentemente do ideal iberista, considerado como utopia dos românticos de 1847, a Confederação luso-brasileira assentava-se em tradições comuns. No caso de uma aliança entre Portugal e Brasil, não seria preciso "apagar as fundas dissenções entre dois povos e já acentuadamente das duas raças que falam linguas diferentes, como n'uma união com a Espanha" (1919: 47).

Essas ponderações acerca de uma aliança luso-espanhola deixaram ecos no período em questão. O ideal iberista não parece ter sido apenas "letra morta na orientação política internacional" de Portugal (CAVALCANTI, idem: 47). Registaram-se discussões, por parte da intelectualidade portuguesa, em torno de uma aliança lusoespanhola e, em alguns casos, as mesmas tomaram uma dimensão de contraposição à ideia de uma aproximação entre Portugal e Brasil. João de Barros, em artigo publicado na Atlântida (1919), intitulado “A Espanha, o Brasil e Portugal ${ }^{103 ”, ~ t e c e u ~ c o m e n t a ́ r i o s ~}$ acerca dessa questão.

Barros relatou que havia recebido cartas daqueles que o julgavam responsável pela propaganda de maior aproximação luso-brasileira, questionando o porquê do

\footnotetext{
${ }^{103}$ O mesmo artigo foi publicado posteriormente na segunda edição de BARROS, João de. Caminho da Atlântida: uma campanha luso-brasileira. Lisboa: Livraria Profissional Editora, 1921, pp. 203-208.
} 
escritor não defender acima de tudo uma aliança luso-espanhola. O poeta dizia não ver qualquer problema numa entente com a Espanha, desde que tal causa não interferisse nos esforços de um melhor entendimento entre Portugal e o Brasil: "Simplesmente não entendo porque razão secreta e fantástica, a aproximação luso-brazileira ha-de ser sacrificada expiatoriamente no altar da nova causa... Não entendo, nem quero entender" (Atlântida, no 41, 1919: 640).

O escritor afirmava que os defensores de uma aliança entre Portugal e Espanha, em detrimento do Brasil, utilizavam como argumento a oposição a proposta de uma Confederação luso-brasileira. Sobre a ideia confederativa, João de Barros afirmou ser exagerada e despropositada, tendo a mesma prejudicado os avanços da campanha de maior proximidade entre os dois países:

“... Ha pouco tempo, no emtanto, appareceu uma forte campanha, no Rio, a favor de uma d'uma confederação politica luzo-brazileira ... Quem o fazia, decerto no melhor dos intuitos, não reparava no exagero do seu amor pelos paizes fraternos - que a todos os extremos de relações affectivas podem chegar, menos ao impossivel ideial de serem uma mesma nação, prejudicando assim o natural o legitimo sentimento de independencia dos dois povos, e esquecendo assim que o Brazil não se libertou do jugo portuguez ha um escasso século, para de novo, e voluntariamente, e mais ou menos disfarçadamente, o acceitar de novo..." (idem: 641).

Em O Sentido do Atlântico (1921), o escritor também demarcou a sua posição de não pertencer ao grupo de entusiastas de tal projeto confederativo ${ }^{104}$. Ficamos, no entanto, com a impressão de que inicialmente houve uma certa simpatia de Barros pela proposta, que o teria levado a abrir espaço na revista Atlântida para a discussão das opiniões sobre o tema, conforme vimos anteriormente. Nesse sentido, as palavras do poeta ao final da entrevista com o diplomata português Bettencourt Rodrigues, quando o mesmo apresentou a proposta da confederação e sugeriu o inquérito acerca

\footnotetext{
104 “Um português amigo, informa-me do Rio de Janeiro, de que eu fui, por vezes, considerado ali como apologista de uma idéa que sempre julguei indefensavel: a idéa de uma confederação política lusobrasileira. Recebi a estranha notícia com sincero espanto e algum scepticismo. Espanto, porque, não podendo eu sequer realizar em pensamento a maneira pratica de efectivar tão disparatada concepção, não saberia, em caso algum justifica-la, quanto mais defendel-a..." (BARROS: 1921: 75).
} 
do tema entre as personalidades portuguesas e brasileiras parecem corroborar essa hipótese:

“... Resta agora saber o acolhimento que o Brasil e Portugal farão a ideia, tão original e tão bela, do eminente scientista. Mas não é dificil augurar-lhe, pelo menos, aquele sucesso de fremente simpatia que cerca e anima todas as iniciativas úteis e, desde o início, destinadas a triunfar na alma complexa das colectividades... " (Atlântida, no 20, 1917: 673).

No entanto, as reações por parte da campanha nativista brasileira contra tal proposição confederativa e, pelos vistos, com adeptos nas fileiras lusas, parece ter causado mal estar dentre os defensores da causa luso-brasileira e o posicionamento desfavorável de Barros a tal idea. O poeta fez questão de se desvincular de qualquer associação ao projeto confederativo, pelo que se declarou ser uma proposta indefensável. Afirmou ter dedicado-se à campanha por um sólido entendimento lusobrasileiro, apoiado no intuito de criar entre as duas Repúblicas "a intimidade de relações que a língua, as tradições, os costumes, a sensibilidade e a idêntica inspiração latina das suas civilizações irmãs, naturalmente suscitam e impõem" (BARROS, 1921: 75-76).

João do Rio também pronunciou-se a respeito da ideia confederativa na Atlântida. O escritor defendeu a necessidade de maior união das nacionalidades para a grandeza futura tanto da República portuguesa quanto da brasileira, no entanto, afirmava não se tratar de fusão política:

“... Para as almas livres, como as nossas, seria impossivel. Em vez dessa irritante fantasia, a maior união é a tendencia natural dos nossos destinos a aproximação dos interesses de cada brasileiro e de cada portuguez, patriotas ambos, dando como resultado na grandeza de duas Repúblicas, a grandeza da raça. Tal liga é imposta pelo amor que nos une, pelo enthusiasmo de fazer maior as duas pátrias, pela certeza de que Portugal não quererá, em hipótese alguma, o mal do Brasil, como não quiz nunca o Brazil de Portugal ..." (Atlântida, no 41, 1919: 638-639).

A revista nacionalista radical Gil Blas, referida no capítulo anterior, lançou uma campanha acirrada contra as manifestações favoráveis a ideia da Confederação luso- 
brasileira. Encontram-se matérias de crítica a tal ideia nas páginas da publicação com bastante frequência entre os anos de 1919 a 1921. Mensagens como a divulgada na matéria intitulada "Brasil, paiz autonomo - abaixo a utopia da Confederação Lusobrasileira!", foram amplamente reforçadas no periódico (Gil Blas, no 19, 19/6/1919: 2).

Em linhas gerais, as matérias sugeriam que tal projeto era investido de uma intenção recolonizadora ${ }^{105}$. Nas palavras do escritor e jornalista brasileiro Raimundo Magalhães (1885-1928): "Vae para tres annos que políticos, escriptores e jornalistas portugueses vivem a pregar a recolonização do Brasil, sob o disfarce amavel de uma alliança, ou melhor, de uma 'Confederação Luso-brasileira' " (Gil Blas, no 4, 13/11/1919: 6).

Astrogildo de Azevedo, do Apostolado Nacionalista ${ }^{106}$, associou o nome de Malheiro Dias e de João de Barros à ideia confederativa (Gil Blas, no 113, 7/4/1921: 7). O autor afirmava que a aproximação político-económica entre Brasil e os Estados Unidos da América era vista como uma ameaça ao poder hegemónico português na sociedade brasileira. A partir disso, propunha-se a "nefasta camaradagem oficial" da Confederação luso-brasileira.

Em artigo sequencial sobre o tema, Azevedo alegava o despropósito que seria tal proposta, tendo em vista o país parasitário no qual havia se tornado Portugal. Sendo assim, não teria o que oferecer ao Brasil: "O Brazil é a grande força que vem surgindo na nova América. É a gloria do futuro. Portugal é a pequena força que vae desapparecendo na velha Europa. É a sombra do passado" (Gil Blas, no 114, 14/4/1921: 3).

Na Atlântida, o tema da confederação é abordado majoritariamente de um prisma positivo, destacando-se os ganhos que poderia trazer para ambos os países. Não aparecem os ecos de rejeição, por vezes virulentos, a tal ideia. A questão da

\footnotetext{
105 Conferir por exemplo; Raymundo Magalhães, "A Recolonização", Gil Blas, 13/11/1919, № 40, p. 6. Paschoal de Moraes, "Intercâmbio ou Recolonização", Gil Blas, 13/11/1919, no 40, p. 10. Trajano de Almeida, "Intercâmbio ou Recolonização?", Gil Blas, no 41, 20/11/1919, pp. 2-3.

${ }^{106}$ Movimento ligado à Ação Social Nacionalista (ASN) teve dentre os fundadores Alcebíades Delamare, nomeado Presidente de Honra da organização. O Apostolado Nacionalista era dirigido por Astrogildo de Azevedo e tinha como meta unir catolicismo e nacionalismo. Conferir JESUS, Carlos Gustavo Nóbrega de. Revista Gil Blas e o Nacionalismo de Combate (1919-1923). São Paulo: Cultura Acadêmica Editora, 2012: 43.
} 
lusofobia no Brasil aparece de forma breve nas páginas da revista como, por exemplo, no artigo de Tristão de Ataíde, pseudónimo adotado pelo escritor brasileiro Alceu Amoroso Lima (1893-1983). Ao fazer uma crónica literária do cenário brasileiro da época, o autor mencionou brevemente o nativismo e caracterizou as relações entre Brasil e Portugal da seguinte maneira:

“... O Brasil é hoje uma nova nação, que guarda do dominio portugues os invenciveis caracteres da raça, mas que nada prende ao antigo reino. Intellectualmente estamos mais próximos de França do que de Portugal. Nossas correntes literárias são muito outras do que em Portugal; nossa lingua já é muito diferente do idioma que nos foi herdado, nossa alma já se transsubstanciou em um novo corpo diverso daquelle que outróra nos foi commum" (Atlântida, no 41, 1919: 566).

Graça Aranha, em carta a João de Barros, criticou o artigo de Ataíde, descredibilizando o escritor: “... Começa o autor por dizer que nós não temos mais nada com Portugal - e que mesmo nunca tivemos nem mental nem sentimentalmente! Isso publicado na Atlântida! Desfaz da approximação de Portugal e Brasil - desfaz do sentimento commum das duas nações!! ${ }^{107 "}$. Concluiu então o diretor da revista em França, recomendando que não fosse publicado mais nada de tão "extravagante crítico" e que João do Rio não endossasse os escritos de Ataíde.

Buscamos revelar, por meio da contextualização da temática da confederação luso-brasileira nas páginas da Atlântida, aspectos importantes do posicionamento do periódico e dos seus diretores em relação à causa da aproximação luso-brasileira. Na parte sequencial do trabalho, procuraremos tratar de abordagens coevas produzidas sobre o Brasil e a sua relação com Portugal, entrecruzando os discursos de revistas de diferentes vertentes teóricas, tais como: A Águia e a Nação Portuguesa.

\section{II.3. Leituras da relação Brasil-Portugal: A Águia e a Nação Portuguesa}

107 Graça Aranha, (N11/116), Paris, 10 de Novembro de 1919. Espólio João de Barros da Biblioteca Nacional de Portugal. 
Em linhas gerais, a virada do século XIX para o XX foi marcada pelo processo de criação ou reestruturação dos Estados Nacionais. O fluxo intenso de mudanças estimulado pela nova dinâmica da economia capitalista global afetaria "desde a ordem e as hierarquias sociais até as noções de tempo e espaço das pessoas..." (SEVCENKO, 2008: 7).

Tratou-se ainda de um processo de reconstrução histórico-sociológico e de reinvenção das tradições e identidades nacionais, que permeou os regimes republicanos instaurados no Brasil e em Portugal.

Algumas das interpretações produzidas nesta época sobre o passado e as então perspectivas presentes e futuras de cada país, ultrapassaram a condição de modelos discursivos e foram incorporadas por segmentos sociais. Melhor dizendo, deixaram as suas marcas, influenciando a maneira como os brasileiros e portugueses se auto identificam e representam.

No cenário brasileiro, o debate intelectual dividia-se entre as teses que apoiavam a continuidade da tradição cultural portuguesa, branca e europeia como plasmadora da identidade nacional e aquelas que defendiam uma ruptura com o passado colonial e imperial. Do lado português, as elaborações sobre o passado reforçavam a imagem de Portugal como o gerador de nações. Construíram-se visões de um passado representificado, com base na gesta dos descobrimentos. Essa lógica pautava-se numa noção de tempo não linear, na qual passado, presente e futuro são indissociáveis criando possibilidades de se dar futuro ao passado, representificando-o (Catroga in: PINHO e NATÁRIO, 2011: 16).

Ao propormos uma leitura das relações luso-brasileiras nos periódicos A Águia, Nação Portuguesa e a Atlântida, visamos desvelar a visão que se projetava de Portugal e do Brasil nesses periódicos com diferentes matrizes teóricas.

Cada uma dessas revistas representava uma corrente do pensamento filosófico-político e literário da época. Assim temos A Águia (1910-1932), como órgão da Renascença Portuguesa ou do Neo-romantismo saudosista, a Nação Portuguesa (1914-1938) como célula do Integralismo Lusitano ou Neo-romantismo Lusitanista e a 
Atlântida (1915-1920) com referência no Neo-romantismo Vitalista ${ }^{108}$. As vanguardas de intelectuais fundadores dessas publicações representavam grupos com importante papel no pensamento filosófico-político no cenário português da época.

A Águia ${ }^{109}$, "revista quinzenal ilustrada de literatura e crítica", teve início em Dezembro de 1910 no Porto, pouco depois da proclamação da República. Iniciou-se com uma edição quinzenal e depois, numa segunda fase, tornou-se mensal. A partir de 1912, constitui-se como órgão do movimento sócio-cultural da Renascença Portuguesa, inaugurando-se a segunda série do periódico, cujo subtítulo passou a ser; "revista mensal de literatura, arte, ciência, filosofia e crítica social".

Na sua primeira etapa, não foi uma revista de doutrinação e esteve sob a direção e propriedade do jornalista Álvaro Pinto. Entretanto, nesse período já contava com a colaboração de escritores, tais como; Teixeira de Pascoaes (1877-1952), Jaime Cortesão (1884-1960), Leornardo Coimbra (1883-1936), os quais iriam integrar a Renascença Portuguesa, dentre outros. É interessante ressaltar, que João de Barros ${ }^{110}$ colaborou nessa fase, sobretudo com poesias, afastando-se depois do grupo e tornando-se um dos fundadores da Atlântida no final de 1915.

A Renascença Portuguesa foi um movimento cultural iniciado em 1912 no Porto, que se manteve ativo durante o primeiro quartel do século XX. Tinha como base um ideal nacionalista vinculado, no plano literário e filosófico, ao neo-garrettismo e a um sebastianismo quase messiânico.

A crise do Ultimatum inglês de 1890, produziu na literatura portuguesa a renovação de um sentimento patriótico de ressignificação dos valores míticos e nacionais. Buscava-se, por meio do sonho, alimentar a esperança duma possível renovação do país, ultrapassando-se o estigma da humilhação impingida pela Inglaterra.

\footnotetext{
${ }^{108}$ Foram feitas considerações sobre o Neo-romantismo Vitalista, do qual João de Barros foi um dos principais expoentes, no primeiro capítulo deste trabalho.

${ }^{109}$ Disponível para consulta, em formato digital, na página da BNP: http://purl.pt/12152.

${ }^{110}$ Colaborações de João de Barros na revista A Águia: "Primavera" (no 3, Janeiro 1911: 6), "Para o Mar" (no 9, Maio 1911: 12), "Manuel Laranjeira" (no 4, 2a série, Abril 1912: 128-129), “Os artistas e a Guerra” (nos 52/53/54, Abril, Maio e Junho 1916: 138).
} 
A partir desse contexto, criou-se um largo movimento intelectual, denominado Neogarretismo. Tomando-se Almeida Garret como modelo, o movimento valorizava o regresso ao passado, a simplicidade da vida rural, o interesse pelo regionalismo, o culto das tradições, o folclore e a busca da pureza da linguagem (CAMEIRÃO, 2000: 21).

O mito de D. Sebastião, também referência para o grupo da Renascença, remetia ao símbolo do redentorismo social e nacional. Durante os séculos XIX e início do XX, o sonho heroico de D. Sebastião, a sua morte na Batalha de Alcácer-Quibir, o mito do seu regresso e a quimera do Quinto Império $^{111}$ serviram de inspiração aos escritores, como forma de superar as angústias e as incertezas da época. O mito apaziguava as inquietações e gerava esperança:

"Assim, o poeta não conseguindo encontrar o lenitivo para a sua angústia face à situação que reinava no país, foi levado a pensar que só 'a construção ou renovação e difusão consequente e multímoda de um grande mito nacional', o mito sebastianista, poderia levantar o moral da nação. E daí 'nascerão as Novas Descobertas, a criação do Mundo Novo, o Quinto-Império. Terá regressado El-Rei D. Sebastião'” (idem: 21).

Enquanto associação sócio-cultural, a Renascença Portuguesa desenvolveu atividades com o propósito educativo e de promover a autonomia dos intelectuais republicanos em relação à esfera política. Fizeram parte desse movimento alguns

\footnotetext{
${ }^{111}$ O Quinto Império é uma crença messiânica e milenarista que aparece reformulada nas profecias de Gonçalo Ennes Bandarra (1500?-1556), nos textos do padre António Vieira no século XVII, na obra de Fernando Pessoa (1888-1935) e também em Agostinho da Silva (1906-1996). O mito tem origem no texto bíblico do Antigo Testamento, no qual o profeta Daniel decifrou o sonho da estátua com pés de barro do rei da Babilônia, Nabucodonosor. O profeta afirmava que depois da magnificência do império babilónico sucederiam outros, segundo a vontade de Deus. De de acordo com as interpretações mais correntes, seriam esses impérios: o Medo-Persa, o Grego, o Romano e o Quinto Império universal. Segundo o Padre Vieira, os quatro primeiros impérios eram pela ordem: o Assírio, o Persa, o Grego e o Romano e o quinto seria o Império Cristão Português. Na leitura de Fernando Pessoa, os quatro primeiros impérios diferiam dos de Vieira, sendo o primeiro o Grego, o segundo o Romano, o terceiro o Cristianismo e o quarto a Europa. "Pessoa fazia assim do seu Quinto Império, Portugal, a nação onde ele próprio teria lugar, ou, como já formulou Jacinto do Prado Coelho, quando em 1964 foram publicados os primeiros textos sobre esta questão: 'Pessoa propõe a Portugal, sua criatura, a aventura espiritual em que ele próprio se empenhou', 'o Quinto Império em que todos os Portugueses, segundo o poeta, deveriam colaborar assemelha-se estranhamente ao que ele próprio empreende pelo desdobramento nos heterónimos [...]'". In: URIBE, Jorge e SEPÚLVEDA, Pedro. "Sebastianismo e Quinto Império: o nacionalismo pessoano à luz de um novo corpus". Pessoa Plural: 1 (P./Spr. 2012): 153. Consultado em: http://www.brown.edu/Departments/Portuguese Brazilian Studies/ejph/pessoaplural/Issue1/PDF/I1A 03.pdf, 12/11/2012.
} 
importantes expoentes do mundo das letras portuguesa, tais como: Jaime Cortesão (1884-1960), Teixeira de Pascoaes (1887-1952), Raúl Proença (1884-1941), António Sérgio (1883-1969), Leonardo Coimbra (1883-1936), Augusto Casimiro (1889-1967), Álvaro Pinto (1889-1957), dentre outros.

O grupo visava criar um público consciente e ilustrado e teve como principal mentor, sobretudo até 1916, Teixeira de Pascoaes com a sua teoria do saudosismo ${ }^{112}$ e, numa segunda fase, Leornardo Coimbra. Privilegiou-se o uso dos termos "regeneração", "ressurgimento" e "renascença", com vistas a insinuar que o enfermo do ocidente, apesar de tudo, devia ter esperanças de levantar-se do seu leito de moribundo e caminhar para a frente (CATROGA in: PINHO e NATÁRIO, op. cit.: 16).

A Águia tornou-se o principal espaço de divulgação ${ }^{113}$ das ideias do movimento:

O fim d'esta revista, como órgão da 'Renascença Portuguesa' será, portanto, dar um sentido as energias intelectuais que a nossa raça possue; isto é, colocá-las em condições de se tornarem fecundas, de puderem realizar o ideal que, n'este momento histórico, abrasa todas as almas sinceramente portuguesas: - Crear um novo Portugal, ou melhor ressuscitar a Pátria Portuguesa, arrancá-la do tumulo de alguns seculos de escuridade fisica e moral, em que os corpos definharam e as almas amorteceram" (A Águia, nำ1, 1912: 1).

Segundo o pensamento de Teixeira de Pacoaes, a saudade era entendida como manifestação suprema do modo de ser português. O saudosismo lusitano, pautado no messianismo, surgia como a única forma de elevação e de redenção do povo. "A Saudade, 'alma da Raça', é a força criadora e redentora, que, sobre a lembrança dum

\footnotetext{
${ }^{112}$ A doutrina saudosista não era consenso entre os representantes da Renascença. Há manifestações críticas contra tal teoria, inclusive nas páginas d’ Águia, por parte de António Sérgio e de Raul Proença. Conferir, por exemplo, António Sérgio, "Regeneração e tradição, moral e economia”, in: A Águia, no 25, 1914: 1-9.

${ }^{113}$ Além de $A$ Águia, o grupo da Renascença também editou o boletim Vida Portuguesa. O "quinzenário de inquérito à vida nacional" foi publicado entre Outubro de 1912 e Novembro de 1915, sob a direção de Jaime Cortesão, perfazendo 39 números com distribuição no Brasil. A partir do no 17, lia-se "Boletim de inquérito à vida nacional" e do no 21 apresentava-se como "Boletim da Renascença Portuguesa". A publicação abordava temas de literatura, artes, ciência, filosofia e crítica social, conferindo atenção especial a divulgação do trabalho na frente educacional desenvolvido pelo movimento. Assim sendo, apresentou-se várias matérias sobre as universidades populares, o ensino infantil, dentre outras questões. Disponível para consulta, em formato digital, no acervo da BNP: http://purl.pt/284/3/\#/282 .
} 
passado inspirado, deve criar o desejo duma redenção sobre a sombras do presente" (CAMEIRÃO, op. cit.: 23).

Nessa conceção havia uma valorização do particular, embora não fosse impedido o acesso ao universal. A Pátria e a Raça participavam do universalismo, porque estavam "intimamente ligadas à Humanidade". Segundo esses princípios, o patriotismo seria a maneira mais autêntica de se ser cosmopolita. Sendo assim, "o 'bom português' devia cultivar em si o patriota que abrange o indivíduo, o pai e o munícipe e os excede" (CATROGA in: PINHO e NATÁRIO, op. cit.: 16).

Defendia-se, portanto, uma República Portuguesa dedicada a atender às demandas sócio-culturais do país, ultrapassando-se a tendência de se reproduzir um modelo político afrancesado. Por povo português entendia-se, sobretudo, as comunidades rurais, devido à sacralização do seu trabalho em comunhão com a natureza (CATROGA, idem: 16).

A interiorização desses valores exigia o corte com a educação clerical e com o enquadramento ultramontano do religioso. Somado a isso, fazia-se necessária uma reforma educativa que abarcasse "as necessidades de sacralidade inerentes aos costumes, bem como as inquietações do ser humano perante os enigmas do mundo e da vida". Somente dessa forma, poderiam ser os valores verdadeiramente renascentes (CATROGA, ibidem: 16).

O movimento da renascença não aceitava, no entanto, o radicalismo agnóstico no tratamento da questão religiosa. Buscava-se "refundar uma vivência da sacralidade mediada, não por Roma, mas por uma Igreja lusitana 'que tão vivas raízes tem na tradição e no espírito da Raça'” (CATROGA, idem, ibid.: 16).

A Águia teve um papel importante no intercâmbio cultural Brasil-Portugal, pois manteve entre seus colaboradores escritores brasileiros ${ }^{114}$ e contou com uma

\footnotetext{
${ }^{114}$ Conferir, por exemplo, Coelho Neto, “A Partida” (no 3, Janeiro 1911: 3-4); Coelho Neto, “Atracção da Terra" (no 4, 2a série, Abril 1912: 118-121); Mateus de Albuquerque, "Eça de Queiroz" (no 7, 2a série, Julho 1912: 32-36); Costa Macedo, "Os Covas" (no 8, 2a série, Agosto 1912: 65-70); Mário de Alencar, "Carta a Carlos Magalhães de Azeredo" (nos 106/107/108, Out a Dez de 1920: 100-124); Rocha Pombo, “A Reacção contra os Intrusos" (nos 109/110/111, Jan a Mar 1921: 37-51).
} 
significativa distribuição no Brasil. Além do que, houve um período em que a revista foi editada no Rio de Janeiro (1920-1921) pelo jornalista português Álvaro Pinto ${ }^{115}$.

Para nós, torna-se interessante acompanhar, sobretudo, a segunda série de $A$ Águia (1912-1921), conferindo especial atenção aos dois anos em que a mesma foi impressa no Rio. Esse período mostrou-se relevante, pois os escritores reunidos em torno da Renascença Portuguesa criaram a Sociedade Luso-Brasiliana e, assim, fundaram a editora Anuário do Brasil.

No seu estudo sobre a trajetória do intelectual-imigrante Álvaro Pinto no Brasil, Raquel Souza ${ }^{116}$ confere destaque ao papel desempenhado por esse jornalista na articulação de um projeto cultural que privilegiava o intercâmbio luso-brasileiro. 0 projeto apareceu materializado nas páginas de A Águia, quando a mesma fora editada no Rio, por meio da secção intitulada "Carta do Brasil". Nesse espaço do periódico foram discutidos diversos assuntos como, por exemplo: as questões do imigrante português no Brasil, as comemorações do Centenário da Independência brasileira, a campanha nativista e temáticas sócio-económicas brasileiras do período, dentre outros.

Na primeira carta, de Abril de 1920, Álvaro Pinto, então um dos diretores da $A$ Águia $^{117}$, referia ao quão bem recebida havia sido a revista e a Renascença Portuguesa no Brasil. Era, pois, dever dar a conhecer Portugal ao público brasileiro com estudo aprofundado acerca da literatura, do desenvolvimento comercial, industrial e dos costumes portugueses.

O tema do imigrante luso no Brasil ocupou considerável espaço nesse artigo. Pinto afirmava que o país necessitava de grande movimento imigratório. Aos

\footnotetext{
115 Álvaro Pinto (1889-1956) foi diretor, secretário e administrador de algumas das mais prestigiadas publicações de Portugal, na primeira metade do século XX. Além dos cargos (secretário, diretor, correspondente) ocupados n'Águia (1910-1925), foi também diretor da revista Ocidente (entre 1937 e 1956). Dirigiu, ainda, a revista Terra de Sol (1924 a 1925), editada no Rio de Janeiro, ao lado do poeta brasileiro Tasso da Silveira, além de outras revistas de mais curta duração.

${ }^{116}$ SOUZA, Raquel dos Santos M. "Um intelectual imigrante: Álvaro Pinto e o projeto de intercâmbio Portugal-Brasil", pp. 3-4. Disponível no endereço eletrónico: http://www.reseau-ameriquelatine.fr/ceisal-bruxelles/MS-MIG/MS-MIG-3-MADALENO-SOUZA.pdf.

${ }_{117}^{11}$ Nessa altura, era também diretor de A Águia o pintor, professor e poeta António Carneiro (18721930). Desde a edição dos números $91 / 92 / 93$ de 1919, o nome do pintor e de Álvaro Pinto constavam na direção do periódico. No entanto, Carneiro ocupava esse cargo desde 1912, ao lado de Teixeira Pascoaes, mantendo-se no mesmo até os nos 118/119/120 de 1921.
} 
portugueses caberia "apresentarem-se com pleno conhecimento dos seus fins", munidos de instrução acerca do trabalho, respeito, tolerância e ordem para com a nova sociedade. Essa deveria ser a premissa para os imigrantes "que buscam em terra alheia o emprego de atividades que não podem encontrar na sua" (A Águia, nos 101/102, 1920: 188).

Segundo o publicista, fazia-se necessário a criação de uma escola que orientasse todos aqueles que desejassem emigrar. Era imperativo organizar o encaminhamento dos imigrantes portugueses para as áreas e atividades do território brasileiro em que fossem realmente precisos. Dessa forma, evitar-se-iam a sobrecarga dos serviços no comércio das cidades litorâneas e as críticas dos movimentos nacionalistas em torno desse perfil da comunidade lusa (idem: 189).

Essa característica da imigração portuguesa foi tema da conferência de Malheiro Dias (“Rumo à Terra ${ }^{118 ”}$ ), realizada em 1917, retomada em matéria de $A$ Águia, por ser considerado pertinente divulgar as ideias defendidas na mesma. Segundo essa conferência, a finalidade principal da colónia lusa no Brasil era ajudar a manter a unidade espiritual brasileira, evitando a tendência a desagregação causada pela imigração de outras nacionalidades. Percebe-se, nesse ponto, uma aproximação à ideia de Sílvio Romero acerca do elemento português no Brasil (1902), referida anteriormente, quando o escritor identificava o imigrante luso como responsável pela manutenção da feição hitórico-cultural do país.

No entanto, a colónia portuguesa pela inclinação a fixar-se no comércio do litoral, enquanto os outros imigrantes dirigiam-se ao trabalho agrícola no interior, afastava-se do seu propósito integrador. Tal conduta causava ainda empecilhos ao desenvolvimento da própria colónia. Nesse quadro, as áreas colonizadas por imigrantes alemães e italianos acabavam por impor-se também nas atividades comerciais, gerando concorrência ao comércio português. Tendo em vista essas questões, defendia Malheiro Dias:

\footnotetext{
${ }^{118}$ Tema referido por Malheiro Dias em entrevista concedida à revista At/ântida (no 19, 1917: 603), citada anteriormente nesse trabalho.
} 
“'... O que é preciso, o que é indispensável é desviar da fascinação urbana os lavradores, que muito melhor poderão colaborar na grandeza do Brasil, na prosperidade de Portugal e na hegemonia da nossa raça comum, estabelecendo-se na terra, cultivando a terra' " ( $A$ Águia, nos 103/104/105, 1920: 36).

Na visão de Álvaro Pinto, os cuidados ao emigrante que deixava Portugal deveriam ser pensados no contexto de um verdadeiro intercâmbio com o Brasil. Não se tratava de uma mera aproximação, mas de "um intenso estreitamento da amizade e contratos, em que Portugal reconhecendo o incalculável auxilio que o Brasil póde dispensar-lhe, se esforce por corresponder a ele trabalhando com igual ardor no engrandecimento do povo irmão" (A Águia, nºs 101/102, 1920: 189).

O jornalista afirmava, ainda, que não era com "missões de amadores, viagens de tres meses, conferencias políticas, bailes e banquetes", as bases em que se dariam o intercâmbio proposto. Para isso, fazia-se necessário um programa acordado entre as Embaixadas e os Ministérios dos Negócios Estrangeiros de cada país, estabelecendo-se um tratamento oficial para o estreitamento das relações (idem: 189).

É bem provável que o objeto das críticas de Álvaro Pinto tenha sido, no caso, João de Barros ${ }^{119}$, que se encontrava na sua segunda viagem ao Brasil, entre Abril e Junho de 1920, realizando conferências em prol de uma aproximação luso-brasileira. Numa outra carta, o diretor de A Águia remeteu-se ao poeta como "vistosa borboleta das letras portuguesas", revelando tensão entre os círculos literários lusos da época:

"Você [João de Barros] sonhou destruir a Águia com a Atlântida. Falhou. Você sonhou destruir as edições da 'Renascença' com as suas. Falhou. Você sonhou reduzir Portugal-Brasil a duas simples pessoas. Falhou. Eu não posso ser seu inimigo, porque absolutamente nada, até hoje, V. tem colhido no meu campo ou eu tentado colher no seu. Cortei em determinado tempo relações consigo, porque o vi demasiado senhor do seu lugar burocrático, tratando-me do alto. Mas, não tive duvida alguma em as reatar,

\footnotetext{
${ }^{119}$ O poeta foi também alvo de crítica em matéria do boletim A Vida Portuguesa, conforme referido, periódico da Renascença Portuguesa. No artigo em questão, João de Barros foi repreendido pelo texto que remetera a um jornal brasileiro, no qual afirmava não haver nada que fosse digno de nota nas letras portuguesas da época corrente, pois os intelectuais encontravam-se absorvidos pela política. Essa afirmação foi contestada, tendo em vista a significativa produção literária da Renascença Portuguesa. Conferir: “O snr. João de Barros", A Vida Portuguesa, no 19, 1/11/1913: 148-149.
} 
quando V. o desejou. Não faço versos ... Sou portanto insuspeito para falar de si. E por isso me atrevo a não concordar com a sua fórmula tão estreita de intercâmbio, que conduz a fazer de V. a expressão máxima da Raça..." (A Águia, nos 112/113/114, 1921: 115).

Podemos inferir, que as querelas entre os grupos literários portugueses estendiam-se ao tratamento conferido à questão das relações luso-brasileiras. A fundação da Atlântida é percebida como concorrência. Por meio dessa espécie de desabafo, percebe-se que Pinto questionava a forma como João de Barros vinha fazendo a campanha de aproximação entre os dois países. Na leitura do jornalista, Barros teria monopolizado a causa, reduzindo-a a uma parceria com João do Rio, em tom de "conversas de café e aventuras galantes" (idem: 116).

Algo que deixou Pinto bastante indignado foi o comentário feito por João de Barros, quando o mesmo esteve no Brasil, dizendo-se ser o único português que não buscava tirar proveito financeiro do país (ibidem: 116). Esta declaração não foi bem recebida, tendo em vista o percurso do publicista que emigrara para o Rio de Janeiro, assim como outros intelectuais portugueses, com o propósito de fundar a editora Sociedade luso-brasiliana e dedicar-se a este projeto em parceria com o escritor António Sérgio. O então diretor de A Águia chegou a insinuar que o recrudescimento do nativismo brasileiro, com o caso dos poveiros e o avanço da linguagem xenofobista, poderia ter sido, de alguma forma, influenciado pela passagem de Barros pelo Brasil (idem, ibid.: 116).

Sobre a campanha nativista, Pinto questionava o facto do elemento luso ser alvo da mesma, visto que era dos imigrantes mais assimiláveis, devido às proximidades culturais:

"Os ataques dos nativistas aos lusos não passam a maior das vezes de paradoxais arrufos de familia entre o Português já assimilado e o Português em via de assimilação... Ao pai português sucede o filho brasileiro, a empresa que começa portuguesa na mão do primeiro continua brasileira na mão do segundo... " (A Águia, nos 101/102, 1920: 190).

Nessa mesma carta afirmava ainda que os maiores detentores e exploradores das riquezas económicas brasileiras eram de agrupamentos ingleses, alemães, 
franceses e italianos. No entanto, conforme mencionado no capítulo anterior, a imprensa nacionalista radical denunciava, sobretudo, o monopólio económico português nos principais centros urbanos brasileiros da época (idem: 191).

Em outro artigo assinado pelo publicista, o tema do nativismo foi retomado. $\mathrm{O}$ autor considerava que essa questão deveria ser tratada com serenidade e estudo calmo. Relativizava o tema, dizendo ter havido em várias épocas conflitos entre brasileiros e portugueses no Norte do Brasil. Entretanto, tais embates localizados teriam sido exagerados pela imprensa portuguesa (A Águia, nos 112/113/114, 1921: 120).

Colocava-se, ainda, como exemplo de emigrante português que tinha sido bem recebido no Rio de Janeiro, onde se dedicava à atividade editorial. $O$ autor frisava, que os ataques mais contundentes aos portugueses resumiam-se, sobretudo, a um panfleto carioca (provavelmente, o Gil Blas), o qual não representava o pensamento do Brasil (idem: 120-121). No tocante a essa discussão, o posicionamento de Álvaro Pinto apresenta-se próximo ao de João de Barros. Conforme vimos, o poeta também analisava o nativismo como algo pouco representativo da visão da sociedade brasileira do período em relação ao português e a cultura lusa.

É difícil mensurar a relevância do intercâmbio cultural fomentado pela A Águia, mas certamente teve o seu contributo ao atualizar os debates presentes em ambas as sociedades, seja no campo literário ou político. Arnaldo Saraiva analisa positivamente o papel da revista nesse contexto, sobretudo, no aspecto da aproximação humana e cultural entre portugueses e brasileiros, em tempos particularmente difíceis:

“... Nenhuma outra instituição, nem nenhum governo, desenvolveu em tal domínio uma ação que se Ihe possa comparar. Porque os intelectuais que idealizaram A Águia e a Renascença Portuguesa não se limitaram a atuações episódicas, não se contentaram com almoços, discursos, reuniões, acordos sem consequência, nem se ficaram pela revista. Eles deram-se conta muito cedo do que em nossos dias se tarda em descobrir: que não pode manter-se viva a cultura portuguesa no Brasil ou a brasileira em Portugal sem a edição de livros portugueses no Brasil e brasileiros em Portugal" (2004: 9192). 
Na Nação Portuguesa, revista do Integralismo lusitano, em número dedicado à prestar homenagem ao Brasil, publicou-se: "Saudemos no Brasil o adolescente heroico nosso herdeiro, continuador da raça e língua nossas, mantenedor da Lusitanidade e do seu ritmo imortal" (Nação Portuguesa, no 11, 1923: 489). Ficamos, assim, com uma ideia da imagem divulgada do país no periódico, ou seja, a de perpetuador da cultura portuguesa na América.

A revista foi criada pouco antes da deflagração da I Guerra Mundial por um grupo de jovens monárquicos, reunidos na Universidade de Coimbra. Circulou de forma seriada entre 1914 e 1938 sem periodicidade definida, com interrupção da publicação no período de 1917 a $1921^{120}$. Tornou-se, portanto, a principal porta-voz ${ }^{121}$ do chamado Integralismo lusitano, movimento que com a implantação da República em 1910, transitou da simples tertúlia literária à ação política.

Fizeram parte desse movimento nacionalista e tradicionalista, por opção estético-filosófica, nomes como: António Sardinha (1887-1925), Alfredo Pimenta (1882-1950), José Hipólito Raposo (1885-1953), Alberto de Monsaraz (1889-1959), Luiz de Almeida Braga (1886-1970), José Adriano Pequito Rebelo (1892-1983), Rolão Preto (1893-1977), dentre outros ${ }^{122}$. Este último, um dos integrantes mais novos dessa primeira geração integralista, estabeleceu os vínculos entre o movimento e os ideias fascistas e primo-riveristas da época.

Eram personagens reconhecidos na comunidade estudantil de Coimbra pelo elitismo e acentuado aristocratismo intelectual. Tinham origem em grande parte na pequena aristocracia ou no latifúndio alentejano, no entanto, nem todos provinham

\footnotetext{
${ }^{120}$ Nesse período publicou-se o diário integralista da tarde "A Monarquia", 12 de Fevereiro de 1917, com Alberto de Monsaraz na direção e redator-chefe, João do Amaral.

${ }^{121}$ Entretanto, não foi cronologicamente a primeira publicação coletiva do movimento integralista. Antes da Nação Portuguesa, editou-se no exílio, na cidade de Gand (Bélgica), a Alma Portuguesa. Foram então publicados dois números, em Maio e Setembro de 1913, cujo subtítulo era Órgão do Integralismo Lusitano. Conferir: CARVALHO, Paulo Archer. Nação e Nacionalismo: Mitemas do Integralismo Lusitano. Dissertação de Mestrado em História Contemporânea de Portugal, Faculdade de Letras da Universidade de Coimbra, 1993: 3.

${ }^{122}$ Cecília Barreira em seu estudo sobre o Integralismo Lusitano elenca uma segunda geração integralista: Afonso Lucas (1893-1946), Manuel Múrias (1900-1960), Pedro Teotónio Pereira (19021972), António Rodrigues Cavaleiro (1902-?), Marcelo Caetano (1906-1980). In: “Três nótulas sobre o Integralismo Lusitano (evolução, descontinuidade, ideologia nas páginas da Nação Portuguesa, 19141926)", Análise Social, vol. XVIII (72-73-74), 1982 - 3. ${ }^{\circ}-4 .^{\circ}-5$. ․․ p. 1422. Disponível em: http://analisesocial.ics.ul.pt/documentos/1223461323N1/BL3vp7Vz81PH1.pdf .
} 
de famílias abastadas. A maior referência ideológica externa do grupo foi o movimento monarquista e nacionalista francês, criado no final do século XIX; a Action Française ${ }^{123}$ (COSTA PINTO, 1994: 26).

A produção intelectual da corrente integralista dedicou-se a estudos históricos sobre a identidade nacional portuguesa. Reinventaram a tradição de uma sociedade orgânica e corporativa, da qual o Portugal medieval teria sido paradigma e que o liberalismo do século XIX, enquanto produto da importação, acabou por destruir. Segundo essa interpretação, entendia-se o período medieval como a fase de maior perfeição da sociedade portuguesa (COSTA PINTO, idem: 25).

Os integralistas defendiam uma Nação organizada e hierarquizada segundo a tradição, em oposição à soberania popular. A forma de representação deveria pautarse no corporativismo dos núcleos tradicionais (a família, os municípios e as profissões) em oposição ao sufrágio universal. Uma Assembleia Nacional representativa dos segmentos sociais, com um caráter consultivo e técnico, deveria substituir o parlamento. Contrapunham, ainda, à centralização do Estado liberal, considerada responsável pela destruição da vida local e pela urbanização descontrolada, uma descentralização do poder anti-cosmopolita e um processo de ruralização da sociedade (COSTA PINTO, ibidem: 29).

Em editorial programático ("O que nós queremos"), apresentado em número inaugural da Nação Portuguesa, essas questões aparecem pormenorizadas. Destacamos aqui alguns pontos do pensamento do grupo:

“Monarquia orgânica tradicionalista anti-parlamentar - A) Tendencia concentradora (Nacionalismo) - Poder pessoal do Rei Chefe de Estado; 1. Função governativa suprema: por ministros livremente escolhidos, especializados tecnicamente, responsáveis perante o Rei [...] 2. Função coordenadora, fiscalisadora e supletoria das autarchias,

\footnotetext{
${ }^{123}$ A revista nacionalista, anti-semita e germanófoba Action Française foi fundada por Charles Maurras (1868-1952) em Paris, no ano de 1908. Principal órgão do Nacionalismo Integral, fundamentado na defesa da monarquia tradicional, hereditária, antiparlamentar e descentralizada. As principais ideias da filosofia de Maurras respaldavam-se num intenso nacionalismo, na crença numa sociedade ordenada e elitista e na defesa da Igreja Católica Apostólica Romana. Conferir, por exemplo, WEYEMBERGH, Maurice. Charles Maurras et la Revolution Française. Paris: Librairie Philosophique J. Vrin, 1992.
} 
locaes, regionaes, profissionaes e espirituaes [...] 3. Funções executivas, fazendo parte da função governativa suprema [...]; defesa diplomática.

B) Tendencia Descentralisadora - 1) Aspecto Economico Corporação: sindicatos operários, patronaes e mixtos, sua personalidade juridica, fiscalisação da empreza, fomento dos interesses comuns, arbitragem, etc. [...] - Nação economica: Politica economica do governo central (Rei, ministros, conselhos técnicos, função supletoria de fomento, protecionismo, tratados de comercio) função de fiscalização e coordenação dos varios graus da hierarquia economica. 2) Aspecto familiar administrativo: - Família: Unidade (patrio poder); Continuidade (indissolubilidade conjugal; vinculação luta contra o absenteísmo; vinculação propriamente dita: morgadio, homestead). - Paroquia: representação de um conjunto de famílias pelos seus chefes. - Municipio: representação de um conjunto mais amplo de famílias pelos seus chefes e de quaesquer outros organismos sociaes de importancia [...] 4) Aspecto espiritual: Intrução primaria no municipio. - Instrução secundaria na provincia. Universidade Autonoma (Coimbra) [...] Religião: Liberdade e privilegios da religião tradicional Catholica, Apostolica, Romana. Proteção a esta religião e prestação de auxilio material em regimen concordatario. - liberdade de congregação. - liberdade de ensino (Nação Portuguesa, no 1, 1914: 4-6).

Por meio desse programa, podemos depreender que os princípios do Integralismo Lusitano divergiam das ideias defendidas pelo grupo portuense republicano da Renascença Portuguesa. A começar pela defesa do regime monárquico, a visão sobre o catolicismo e todo um ideário de sociedade inspirado num Portugal feudal, que se projetava num plano de regeneração do país.

Enquanto o grupo da renascença via na instauração do regime republicano novas possibilidades de regeneração de Portugal e, para isso, preconizavam o rompimento dos laços com a Igreja Católica, os integralistas opunham-se a essas conceções. Para os últimos, a República implantada representava uma nova etapa de decadência do país. Nesse sentido, os integralistas buscavam a regeneração por meio do retorno à integralidade do espírito católico que fizera Portugal. Havia, ainda, uma 
defesa comum às duas correntes em torno da importância da ruralidade, no entanto, apoiada em pressupostos teóricos diferentes.

A primeira série da Nação Portuguesa (1914-1916) ostentava o subtítulo "Revista de Filosofia Política", sob a direção de Alberto Monsaraz. Dessa fase inicial emergiram alguns dos nomes já citados e com maior destaque na geração integralista. A partir da segunda série (1922-1924) $)^{124}$, foi dirigida por António Sardinha e juntaramse outros nomes ao corpo editorial, tais como: Afonso Lopes Vieira (1878-1946), Castelo Branco Chaves (1900-1992), Vieira de Almeida (1888-1962) e Avelino Soares. Passou a apresentar o subtítulo; "Revista de Cultura Nacionalista". O nosso interesse concentra-se nesses dois momentos da revista.

Os responsáveis pelo periódico abordaram, sobretudo, temas voltados à economia e à política. Conforme vimos, defendiam a monarquia tradicional, não absolutista e anti-parlamentar, bem como os privilégios e papel da religião católica na sociedade portuguesa. Fomentaram uma herança nacionalista militante, com o objetivo de promover o ressurgimento nacional. A defesa de um conjunto de ideias nacionalistas, com vista a um renascimento do país também era intuito da Renascença Portuguesa, reunida em torno da revista A Águia, referida anteriormente.

Segundo Barreira, a colaboração do poeta, historiador e político António Sardinha na Nação Portuguesa foi marcante, tornando-se um dos integralistas mais celebrizados. Escreveu grande parte dos editoriais e também foi responsável pelos principais textos de doutrinação política do periódico. Podemos destacar três temas

\footnotetext{
${ }^{124}$ Publicou-se ainda: III Série, cujo subtítulo permanecia "Revista de Cultura Nacionalista" (1924-1926); sob a direção de António Sardinha, apenas nos 2 primeiros números, devido a sua morte a 10 de Janeiro de 1925. Após o ocorrido, assumiu a direção do periódico Manuel Múrias e Rodrigues Cavalheiro. Na IV Série (1926-1928) manteve-se o mesmo subtítulo e o diretor foi Manuel Múrias. Ocupou o posto de Secretário Marcelo Caetano, desde Novembro de 1927. Na V (Julho de 1928 a Junho de 1929) e VI (1929-1931) séries conservou-se sob a mesma direção e secretariado. Depois de 1931, a revista passou a ser publicada em volumes. Ao longo desse período, permaneceu sob a direção de Manuel Múrias e teve Fernando Campos como secretário. Volume VII (12 números, 1932-1933). Volume VIII, quatro fascículos de 1933 a 1934. Volume IX, seis fascículos, 1934. Volume X, seis fascículos de 1936 a 1937 . Volume XI, seis fascículos de 1937 a 1938. Segundo Barreira, Manuel Múrias imprimiu à Nação Portuguesa uma orientação (de 1925 a 1938) que, paulatinamente, distanciou-se do Integralismo e foi assumindo um perfil de obediência e passividade requeridas, à mentalidade do regime salazarista (1982: 1424).
} 
aos quais o escritor dedicou-se mais rigorosamente: o hispanismo, o municipalismo e a recuperação dos teóricos (Herculano, Garret e Teófilo Braga) da contra-revolução (1982: 1423).

Interessa-nos aqui aprofundar o conceito de hispanismo, por ser bastante significativo para entendermos como essa corrente pensava a formação históricocultural de Portugal e o papel do Brasil nesse conjunto de referências. A tese da hispanidade, defendida pelos integralistas e sobretudo nos artigos de Sardinha, opunha-se ao modelo de latinidade propagado por parte da intelectualidade francesa desse período. Segundo a visão hispanista, a Península Ibérica era considerada a essência da civilização cristã ocidental. Um ponto importante nesse debate, é que os integralistas propugnavam apenas a unidade espiritual e não política entre Portugal e Espanha.

Num artigo intitulado "O genio peninsular", Sardinha inicia o texto referindo-se ao 12 de Outubro, data da chegada de Colombo à América, quando é celebrada a Fiesta de La Raza em Espanha. Definiu raça no sentido de civilização e afinidade moral, não se tratando somente do aspecto étnico. Afirmava que na literatura do século XVI, até mesmo em Camões, o termo "hespanhoes" era utilizado para se referir as gentes que habitavam a Península Ibérica, incluindo-se os portugueses:

"Dentro deste quadro, a unidade hispânica se comprendia como uma especie de super-nacionalismo, tão intimamente cimentado na consciencia da gloriosa época de Quinhentos que Camões, cantando a plenitude da afirmação portuguêsa, a incluia sem desdoiro nem subalternização no molde físico e cultural que a Península representava perante o mundo curvado ao prestigio das suas irradiações"(Nação Portuguesa, no 4, 1922: 150-151).

Tratava-se, portanto, de se recuperar um sentimento espiritual de pertença ao denominador comum; a "madre Hispania". Essa unidade remetia ao período dos descobrimentos quando "cavaleiros da humana energia, espanhois e portugueses ampliaram os roteiros da civilização... [e] afirmaram pereduravelmente um tipo inconfundível, - o tipo «hispânico» em que Camões [...] nos inseria sem desdoiro, ao chamar-nos «huma gente fortissima da Espanha» "... (idem: 158). 
Segundo Barreira, a Hispânia de Sardinha inscreveu-se como uma utopia atemporal, no entanto, apareceu num momento político específico, isto é, no Governo de Primo Rivera (1923-1930). Iniciava-se uma experiência de ditadura nacionalista em Espanha, a qual poderia influenciar a Península. Breves foram as notas, antes de 1922, em que o autor se tenha dedicado a tecer comentários sobre uma política ibérica (1982: 1428).

O Brasil surge nos textos da revista, sobretudo, naqueles escritos por António Sardinha, quando o autor trata do conceito de Hispanismo. Nesse caso, ao conceito de hispanismo estendido às Américas somava-se o prefixo Pan, reforçando-se assim a ideia de um movimento para além da península ibérica. O Pan-hispanismo é entendido como a união entre Portugal, Espanha e os países "irmãos" da América, como forma de combater a doutrina que pregava a solidariedade política e económica entre os países americanos; o Pan-Americanismo ${ }^{125}$ (Müller, 2011: 184-185).

No artigo "A Lição do Brasil", dedicado ao escritor nacionalista brasileiro Jackson de Figueiredo ${ }^{126}$, Sardinha discorreu sobre o papel do Brasil no Hispanismo. Primeiramente, referiu-se ao país como a grande obra lusa, materializando os mais altos serviços prestados por Portugal à civilização: “... Se outro título de glória não possuíssemos, o de descobridores e fundadores do Brasil chegaria suficientemente para nos conceder as grandezas da imortalidade!" (Nação Portuguesa, no 11, 1923: 547).

\footnotetext{
${ }^{125}$ Visava-se, por meio do Pan-americanismo, preservar a integridade do Continente Americano contra outros continentes, sobretudo, o Europeu. A origem desses princípios remonta ao processo de independência da nações americanas das antigas metrópoles europeias. Tal pensamento acentuou-se com a Doutrina Monroe (1817-1825), quando o então presidente dos E.U.A prescrevia a autonomia dos países americanos, simbolizada pela frase "América para os Americanos". A corrente fortaleceu-se no final de 1889, quando foi convocada a Primeira Conferência Pan-Americana pelo governo estadunidense. Conferir, por exemplo: LOGUERCIO, Edgardo Alfredo. Pan Americanismo versus Latino Americanismo. Origens de um debate, na virada dos séculos XIX-XX. Dissertação de Mestrado, Programa de Integração da América Latina da Universidade de São Paulo, 2007. BETHEL, Leslie (org.). História da América Latina, São Paulo, EDUSP/Imprensa Oficial do Estado, Brasília: FUNAG, 2001, vol. III.

${ }^{126}$ Já referido no primeiro capítulo desse trabalho, Jackson de Figueiredo colaborou inicialmente com o movimento nacionalista mais radical fundador da revista Braziléa (1917-1918), aproximando-se posteriormente do catolicismo. Foi um dos organizadores do movimento católico leigo no Brasil. Fundou, em 1922, o Centro Dom Vital e a revista A Ordem (1921-), por meio dos quais combateu o comunismo, o liberalismo e a revolução de modo geral.
} 
Na sequência, dentre as considerações sobre o sentimento nacionalista em Portugal, afirmava que o Brasil associava-se à sorte do país luso quer pelo passado comum, como pela função que Deus the reservava num amanhã resplandecente configurando-se a aproximação fundamentada na Hispanidade:

“... Ao lado da espontânea aproximação que apertará cada vez mais Portugal ao Brasil, formando os dois países um bloco indestrutivel- o bloco do lusitanismo, o conceito envolvente do hispanismo revela-senos como forçosa conclusão, abrangendo consigo, além de Espanha, nossa irmã, vinte nacionalidades que ela intrepedamente semeou por entre perigos e arrojos através da selva americana" (idem: 547).

Segundo Müller, a partir dessas considerações, Portugal arvora-se numa posição de superioridade em relação ao Brasil. Transfigura-se no "pai amoroso" que abriria ao filho primogénito as portas da "Hispânia", constituindo-se como o elo fundamental dessas relações. Seria pela herança cultural lusa que o Brasil teria o seu espaço nesse grande projeto transnacional, o qual visava, especialmente, fortalecer o homem e a raça ibérica (2011: 188).

Sardinha, no mesmo artigo, aprofunda a imagem do Brasil como continuador do génio português no mundo americano. Para isso, recorreu às obras do escritor brasileiro Elysio de Carvalho ${ }^{127}$. Nessa perspectiva, o brasileiro seria fruto da civilização mediterrânea, que se estabeleceu e desenvolveu naquela parte da América. De acordo com Carvalho, não podia ser o índio o tipo nacional e o legítimo brasileiro, conforme alimentava a corrente romântica. Por brasileiro não entendia-se o homem físico, mas o indivíduo moral que se formou histórico e socialmente: “... Brasileiro não pode ser nem o índio, nem o africano, nem o europeu. Só pode ser o Brasileiro, isto é, o tipo que saiu da fusão dessas raças", fruto, portanto, da civilização mediterrânea (Nação Portuguesa, no 11, 1923: 549).

\footnotetext{
${ }^{127}$ Elysio de Carvalho (1880-1925) foi um escritor de origem alagoana, que participou ativamente do debate sobre a questão nacional na Primeira República brasileira (1889-1930). Carvalho, assim como outros intelectuais deste período, dedicaram-se a investigar as origens dos problemas nacionais e o seu diagnóstico, além de propor soluções brasileiras para o país. O pensamento do autor destacou-se pelas características lusófila, ibero-americanista e autoritária. Dentre as principais obras, podemos citar: Brava Gente (1921), Os Bastiões da Nacionalidade (1922), Laureis Insignes (1924) e Suave Austero (1925). Conferir: LEMOS, Clarici Caldini. Os Bastiões da Nacionalidade: Nação e Nacionalismo nas obras de Elysio de Carvalho. Dissertação de Mestrado em História, Universidade Federal de Santa Catarina (UFSC), Florianópolis, 2010.
} 
Ainda de acordo com o integralista, manifestava-se contra o pensamento lusófobo nativista brasileiro, o nacionalismo de Elísio de Carvalho e de Alberto Torres $^{128}$. Nesse sentido, reforçava-se a ideia de que a ascendência portuguesa era uma honra para o Brasil. Portanto, a partir dessa visão que reconhecia a tradição histórica cultural portuguesa como formadora do Brasil, o nacionalismo brasileiro uniase ao nacionalismo português. Concluía Sardinha:

“Para o brasileiro nacionalista a história de Portugal é sua até, pelo menos, a essa primeira Missa do desembarque da gente lusíada na terra ainda enigmática de Santa Cruz. É sua em todos os primores da língua que falamos e que põe no nome de Camões o expoente máximo de uma civilização em que o Brasil se inclui no mesmo pé de igualdade que Portugal. Orgulha-se o nacionalismo brasileiro da sua ascendencia portuguesa. Orgulha-se a nação portuguesa da sua descendencia brasileira..." (idem: 550).

É interessante observar nesse contexto, o facto de António Sardinha buscar minimizar os conflitos decorrentes da política de exploração metrópole-colónia, enfatizando que o Brasil, mesmo enquanto colónia portuguesa, recebera um tratamento diferenciado. Fora sempre uma parte transplantada de Portugal além-mar e não meramente um sítio exploratório (MÜLLER, 2011: 199).

Em "Definindo intenções", editorial do número da Nação Portuguesa dedicado ao Brasil, explica-se que o intuito de se prestar uma homenagem ao país era também o de se promover uma maior aproximação espiritual entre a "pátria do além-Atlântico" e Portugal. Tendo em vista que pertenciam a um tronco cultural comum, aspirava-se a formação de um «bloco hispano-americano» ligado pelo Atlântico, que "como «mare nostrum», se volva num lago emmoldurado pelos descendentes de quantos outrora,

\footnotetext{
${ }^{128}$ Alberto Torres (1865-1917) foi advogado, político e jornalista. Homem de ação e de pensamento, republicano e abolicionista, dedicou-se a estudar a realidade brasileira desenvolvendo uma conceção nacionalista da História. Seu pensamento, sobretudo, no que concerniu ao elogio da miscigenação influenciou um grupo de escritores, o qual mais tarde filiou-se ao integralismo brasileiro. Da sua experiência como homem público resultaram algumas importantes obras: Vers la paix (1909), Le problème mondial (1913), A organização nacional (1914), O problema nacional brasileiro (1914) e As fontes da vida no Brasil (1915). Conferir: BARIANI, Edison. O Estado Demiurgo: Alberto Torres e a construção nacional. Caderno $\mathrm{CRH}$, vol. 20, no. 49, Salvador Jan./Apr. 2007. Disponível em: http://www.scielo.br/scielo.php?pid=S0103-49792007000100013\&script=sci arttext .
} 
partindo da Península Madre, o rasgaram ao cortejo triunfal das idades-modernas" (Nação Portuguesa, no 11, 1923: 493).

No mesmo artigo, tratou-se ainda de marcar posição contra os "embaixadores intelectuais" que se auto-atribuíam uma representação pouco legítima de Portugal em terras brasileiras. Colocava-se em causa os exageros retóricos que procuravam “reduzir Portugal e Brasil, política e economicamente, a um termo único!". A esse respeito, aconselhava-se examinar com cuidado, inclusive a proposta da confederação luso-brasileira defendida com patriotismo por Bettencourt-Rodrigues (idem: 492).

Em conferência publicada na Nação Portuguesa, no mesmo número em homenagem ao Brasil, Bettencourt-Rodrigues ${ }^{129}$ discorreu sobre as relações entre Portugal, Brasil e a diplomacia inglesa. Nessa exposição, o defensor da ideia de uma confederação luso-brasileira, fez considerações acerca do período histórico em que o Brasil fôra elevado à condição de Reino Unido a Portugal e Algarves, em 1815. O autor remeteu-se a essa estrutura política, criada no Governo de D. João VI, como a primeira forma de confederação entre os dois países.

A partir dessa questão, conjeturou sobre o acirramento do desentendimento político, que culminou no processo da Independência brasileira em 1822 e sobre os interesses da Inglaterra em apoiar essa rutura entre Brasil e Portugal:

"O que é certo é que uma nação, como a Inglaterra, receava êsse poder nascente do Brasil, como receava, antes da separação o futuro poderio de um império lusitano, como o que sonhara D. João IV ao dizer que 'se possuisse só o Brasil, com o reino de Angola, as praças de África, os Açores e Cabo Verde, e, juntos esses Estados com Portugal, não trocaria a sua condição pela de nenhum outro príncipe da Europa' " (Nação Portuguesa, no 11, 1923: 511).

Rodrigues afirmava, ainda, que as razões que fizeram com que a diplomacia inglesa tivesse apoiado a separação entre Portugal e Brasil naquela altura, deveriam servir de motivação para a busca de uma união entre os dois países. Dever-se-ia, no entanto, preservar a autonomia de cada país e promover uma solidariedade em todas

\footnotetext{
129 Já mencionado na parte anterior, quando abordamos a proposta da confederação Luso-Brasileira na Atlântida e também a obra escrita por Rodrigues sobre o tema.
} 
as questões e problemas de ordem internacional e em tudo que se relacionasse à segurança e à defesa de ambos os países.

Nessa exposição, o projeto confederativo assumia um papel dentro de uma aliança hispano-americana. Rodrigues defendia uma Confederação Luso-Brasileira que não interferisse na independência material e moral dos povos confederados. Dessa forma, num primeiro momento, visava-se a formação da confederação entre Portugal e Brasil e depois uma aliança com a Espanha e as Repúblicas espanholas da América: “... assim acabaria por se constituir um novo e grande bloco, o bloco luso-hispanoamericano, ao qual não tardaria a juntar-se as outras nações latinas" (Nação Portuguesa, no 11, 1923: 512).

A revista Atlântida, no pós-guerra, alimentou a ideia do latinismo, que expressava a hegemonia da cultura francesa, da qual Portugal, Espanha e o Brasil eram herdeiros. A Nação Portuguesa defendeu o Hispanismo e o papel do Brasil nessa aliança hispano-americana. Segundo essa visão, Espanha e Portugal equilibravam-se em harmonia de poderes. O latinismo, nesse último caso, estava vinculado ao catolicismo: "O catolicismo que amamentou a Europa e insuflou à América o hálito divino da existência..." (SARDINHA, apud MÜLLER, 2011: 199-200).

No seu estudo sobre um conjunto de revistas portuguesas, dentre as mesmas a Atlântida e a Nação Portuguesa, Fernanda Müller tece considerações acerca do papel dessas publicações na 'construção' do imaginário de comunidade (união, espiritualidade) luso-brasileira. Segundo a autora, essas revistas dedicaram-se a difusão e cooptação do público leitor, com a finalidade de angariar adesão que pudesse viabilizar os projetos arquitetados por essa elite intelectual manipuladora (2011: 280).

Na interpretação de Müller, “as 'estratégias amistosas' divulgadas nas revistas desde finais do século XIX até, aproximadamente, 1922 sugerem que: “... cada iniciativa aparentemente isolada de cada periódico no fim integrava um plano e projeto maior de 'integração luso-brasileira', justificada pela ligação afetiva e cultural mas visando somente o beneficiamento e fomento econômico de Portugal" (idem: 280). 
Entendemos o ponto de vista da autora, mas temos alguma dificuldade em partilhar das mesmas conclusões. As mensagens em torno de uma união luso-brasileira divulgadas por tais periódicos, com ênfase na Atlântida, A Águia e a Nação Portuguesa, encontram-se impregnadas por um imaginário da época, ainda fortemente marcado pela herança colonizadora.

Reivindicava-se uma filiação e reconhecimento do Brasil em relação à obra lusa. Não devemos ignorar que o interesse económico fazia parte de toda a retórica da aproximação literária-cultural entre os dois países. No entanto, as elites intelectuais favoráveis à causa luso-brasileira encontravam-se imbuídas de uma noção de fortalecimento da cultura portuguesa, considerada comum e formadora da cultura brasileira num contexto de imperialismos culturais.

$\mathrm{Na}$ sequência desse trabalho, nos dedicaremos a recuperar as discussões presentes nas obras de João de Barros, destinadas à causa da aproximação lusobrasileira, publicadas como resultado da sua terceira viagem ao Brasil, em 1922. Esse ano foi marcado pelas representações produzidas nas comemorações do I Centenário da Independência Brasileira. Barros fez parte da comitiva presidencial, liderada pelo então presidente António José de Almeida, que foi prestar homenagens ao Brasil nesse evento. São desse período as obras: Heróis Portugueses no Brasil (1922), Portugal, Terra do Atlântico (1923) e Olavo Bilac e Euclides da Cunha (1923).

\section{CAPÍTULO III.}

\section{JOÃO DE BARROS E OS DIÁLOGOS COM O BRASIL QUE COMEMORAVA CEM ANOS DE INDEPENDÊNCIA}

O ano de 1922 é tratado pela literatura como emblemático, no contexto das iniciativas de aproximação entre Portugal e Brasil. Alguns eventos significativos foram promovidos nessa altura, os quais marcaram a história das relações entre os dois países. No entorno das comemorações do I Centenário da Independência brasileira, realizou-se a travessia aérea Lisboa-Rio de Janeiro, a viagem do então presidente 
António José de Almeida a convite do Presidente brasileiro e a participação de Portugal na Exposição Universal do Rio de Janeiro.

Os jornais e revistas da época produziram muitas representações ${ }^{130}$ acerca desses acontecimentos, assumindo grande dimensão de fundo simbólico. Embora esses temas sejam mais conhecidos, é importante atentarmos para as imagens e leituras que emergiram nesse momento acerca das relações luso-brasileiras.

Interessa-nos, conforme nossa proposta ao longo do trabalho, recuperar o pensamento de João de Barros acerca das relações Portugal-Brasil nesse contexto, destacando-se as seguintes obras publicadas no período: Heróis Portugueses no Brasil (1922), Portugal, Terra do Atlântico (1923) e Olavo Bilac e Euclides da Cunha (1923). Essas obras foram produzidas em decorrência da terceira viagem do poeta ao Brasil, que fez parte da comitiva presidencial.

Em Portugal, terra do Atlântico, faz um balanço dos últimos acontecimentos das relações luso-brasileiras, apresentando algumas das suas ideias acerca da formação de Portugal e sua vocação atlântica. Barros, afirmava que dentre os mandamentos do seu patriotismo havia um ponto importante: "amar o Brasil como se ama Portugal". Isto justificava-se pela significado do Brasil na História Portuguesa. Segundo o poeta, dever-se-ia entender, que a maior vitória do esforço luso foi ter edificado no território brasileiro "uma nação livre e autónoma, mas alicerçada em sangue português, em tradições portuguesas, e fazendo falar a sonora língua dos seus descobridores a uma população infinitamente mais numerosa do que toda a população da antiga metrópole" (Portugal, terra do Atlântico, 1923: 119-120).

$\mathrm{Na}$ conferência acerca do contributo dos escritores brasileiros Euclides da Cunha e Olavo Bilac, Barros pretendeu dizer da sua admiração pelo Brasil, por meio de trechos das obras dos dois expoentes das letras brasileira. Destacaram-se nessa obra, as palavras de apresentação proferidas pelo então embaixador do Brasil em Portugal, Cardoso de Oliveira, sobre o poeta:

${ }^{130}$ Conceções do mundo social em disputa, determinadas pelos interesses dos grupos que as forjam. CHARTIER, Roger. A História Cultural: entre práticas e representações. Lisboa: Difel, 2002. 
"Como em casa própria entra João de Barros no Brasil, onde seu nome é a todos familiar; e sua obra conhecida, aplaudida e saboreada, como os melhores frutos dos pomares literários brasileiros. Sua pessoa é lá querida e festejada. Porque, em sã verdade o digo, com muito gôsto e sem favor algum, - bastando citar em apoio Caminho da Atlântida, Sentido do Atlântico, A Energia Brasileira, A Aproximação Luso-Brasileira e a Paz e O Grande Brasil, que sei em preparação, - João de Barros tem sido de longa data, na imprensa, na tribuna e no livro, uma das mais poderosas alavancas da maior amizade entre os dois países irmãos" (Olavo Bilac e Euclides da Cunha, 1923: 16-17).

Em Heróis Portugueses no Brasil, o qual trataremos a seguir, o autor buscou reabilitar a memória daqueles vultos considerados os criadores do império ocidental luso, reafirmando a tradição portuguesa na formação do Brasil: “[...] nem por se ter tornado há um século Nação independente e livre, [o Brasil] deixa de ser uma pura glória do nosso esfôrço ultramarino. Nada pretendemos hoje do Brasil, senão o respeito sincero dêsse passado, comum tanto a êle como a nós [...]" (1922: 91).

\section{III.1. "Heróis Portugueses no Brasil" e as comemorações do Centenário da Independência Brasileira (1922)}

A comemoração do Centenário da Independência, em 1922, foi um momento de produção de visões conflitantes acerca da herança portuguesa, vinculadas às discussões sobre a identidade nacional e suas ressignificações. Segundo estudo de Marly Motta ${ }^{131}$, o início da década de vinte foi marcado por um acirrado debate acerca da nação brasileira e os seus rumos, às vésperas de completar cem anos de vida independente. As celebrações mobilizaram a intelectualidade dos dois principais centros urbanos do país, na altura; Rio de Janeiro e São Paulo.

Ao avaliar o papel das figuras históricas, ao julgar o passado colonial e as realizações republicanas, as celebrações centenárias suscitaram discussões sobre a formação e as perspectivas da sociedade brasileira. Questionava-se, sobretudo, o atraso do país, que ainda não havia embarcado na tão almejada modernidade.

${ }^{131}$ A nação faz cem anos: a questão nacional no centenário da independência. Rio de Janeiro: Editora FGV: CPDOC, 1992. 
O grande desafio, segundo a avaliação dos intelectuais do período, era o de superar o passado recente, configurado pelos desencantos com o regime republicano e uma Belle Époque falida, após a I Guerra. Necessitava-se, diante desse quadro de desilusões, de buscar novos parâmetros para se definir uma nação moderna. Nesse sentido, o centenário de 1922 envolveu a intelectualidade brasileira na tarefa sempre renovada de criar a nação, delinear a identidade nacional e, sobretudo, construir um Brasil moderno (MOTTA, 1994: 3-4).

As grandes comemorações de eventos fundadores (os Centenários das Revoluções Francesa e Americana, os IV Centenários da viagem de Colombo e Vasco da Gama) foram inventadas no processo de formação dos Estados-Nação europeus, ao longo do século XIX. Tais celebrações evidenciam as práticas de ritualização da história, adotadas pelos poderes políticos instaurados. Da perspectiva da relação entre memória e história, presente na filosofia positivista da época: “[...] a mobilização da memória dos mortos era decisiva para a solidificação dos elos sociais entre os vivos [...]" (CATROGA, 1998: 222).

Ao lançar mão das formas ritualistas de evocar o passado, “[...] os Estados-Nação apoiaram o desenvolvimento de uma religiosidade cívica que teve nas comemorações um dos seus ritos essenciais que funcionavam como um complemento ou um sucedâneo das religiões tradicionais" (CATROGA, idem: 222-223).

Os paradigmas de modernidade e de progresso atuaram hegemonicamente nas correntes de pensamento que marcaram os fins do XIX e grande parte do século XX. Embora o conceito de modernidade incorporasse a noção de um tempo progressivo e linear, que valorizava o presente e a expectativa do futuro, a importância do passado teve o seu lugar preservado. A partir dessas considerações, podemos entender os significados atribuídos pelo Governo Republicano brasileiro e as elites intelectuais e políticas da época, envolvidas no projeto de disseminação de uma cultura das grandes celebrações nacionais.

Havia uma necessidade por parte da República em demarcar o tom da comemoração da Independência dentro de uma leitura histórica republicana, 
instaurando um afastamento da imagem do marco de fundação da nacionalidade associada à monarquia. Anteriormente, deu-se o debute do então recém Governo republicano na organização da primeira grande celebração da nação: o quadricentenário do descobrimento, em 1900.

Naquela contexto, criou-se uma associação especialmente para a programação das celebrações; a Associação do IV Centenário. O Instituto Histórico e Geográfico Brasileiro destacou-se na organização dos preparativos. Deve-se referir, que a instável situação financeira do país na época e os conflitos políticos instaurados no decorrer dos dez primeiros anos da República brasileira limitaram as dimensões dos festejos (LIPPI OLIVEIRA, 2000: 187).

As celebrações contemplaram dois públicos distintos: o letrado e o popular. $\mathrm{O}$ público letrado foi agraciado com os atividades realizadas pelo Instituto Histórico e Geográfico Brasileiro. Aos segmentos populares dedicou-se especialmente a Associação do IV Centenário, com o intuido de aliciá-los a participar dos festejos. Buscou-se, sobretudo, despertar um sentimento patriótico e comunitário, por meio do uso de imagens, hinos, cortejos, dentre outras.

A imagem do Brasil de 1900, projetada no centenário dividiu-se em duas versões da História. A versão eurocêntrica-portuguesa da "descoberta" e invenção de um "novo mundo" civilizado. Nessa visão, concebia-se a colonização europeia como uma prática civilizadora e, sendo assim, a Humanidade caminhava num sentido de evolução e "progresso" que aproximaria os povos colonizados dos padrões culturais e de desenvolvimento dos colonizadores. Essa versão predominou nos festejos do centenário, nos quais valorizou-se a herança portuguesa, branca e europeia, que ligava o passado brasileiro à herança ocidental desde sua fundação.

No entanto, a versão americana também foi incorporada às celebrações e manifestou-se no destaque conferido à presença indígena na História brasileira. Fruto de uma matriz historiográfica que promoveu a recuperação da cultura indígena, recuperando-a nas origens do bandeirante. Esse destemido explorador dos sertões representava a conjugação entre o branco e o índio, sintetizado na figura do mameluco. O mameluco, esse "caboclo forte", contribuiu para a formação da 
nacionalidade brasileira. Essa versão teve maior aceitação junto à elite paulista, no entanto conforme referido, a visão lusocêntrica manteve-se hegemónica no imaginário histórico do IV centenário do descobrimento (LIPPI OLIVEIRA, 2000: 188).

Nas comemorações portuguesas do quadricentenário, em grande parte dos discursos, destacou-se a imagem das relações luso-brasileiras numa perspectiva paternal e fraterna, segundo Maria João:

"De modo geral, considerava-se que o Brasil era como um filho querido de Portugal que, tendo alcançado a idade madura, se tinha emancipado do progenitor. Esta ideia salientava a estreita relação histórica existente entre as duas nações e o papel de Portugal como país colonizador. Mas os termos da relação não eram de plena igualdade, visto que a figura paterna comporta uma certa autoridade e superioridade em relação ao filho. Por isso, começou a ser também utilizada a imagem de uma relação entre países e povos irmãos. Colocavam-se, assim, os portugueses e os brasileiros em pé de igualdade, unidos por uma história comum e por relações fraternas. A imagem tornou-se recorrente nas comemorações e até no discurso político-diplomático ${ }^{132 " \text {. }}$

Esses breves apontamentos sobre os sentidos desses festejos e o Centenário de 1900, auxilia-nos a situar melhor o embate de ideias e significados presentes nas comemorações da Independência.

Do ponto de vista económico, prevalecia no período uma grave crise marcada pelo comportamento de uma economia predominantemente primária-exportadora dependente do preço do seu produto básico; o café. A mesma teve início na segunda metade de 1920, no Governo Epitácio Pessoa, com ápice em 1922, arrastando-se até o final do mandato de Artur Bernardes (1922-1926). Mesmo diante desse cenário, foi efetuado um considerável programa de investimentos no Rio de Janeiro, então capital federal, considerada uma espécie de grande vitrine do Brasil. A infra-estrutura necessária aos projetos envolveu grande soma de dinheiro público, com vistas à Exposição do Centenário de 1922 e obras destinadas a urbanização da cidade (FRITSCH, 1993).

132 JOÃO, Maria Isabel. "Percursos da Memória: centenários portugueses no século XIX". In: Camões, Revista de Letras e Culturas Lusófonas, no 8, [online], Jan/Mar de 2000. https://www.institutocamoes.pt/revista/percursmemo.htm . 
Mais uma vez, uma reforma urbanística estava na pauta das comemorações de um centenário, conforme ocorrera anteriormente em $1900^{133}$. Essa nova reforma afirmava-se como continuidade do projeto de modernização do Rio de Janeiro, que deveria apresentar-se à altura de sediar a exposição universal, onde estariam representados vários países.

O delineamento de novos pressupostos para a uma dada modernidade integrou as discussões sobre o arrasamento do Morro do Castelo na capital federal. Desde meados do século XIX, foram propostas avaliações para se reformar a topografia da parte central da cidade. Eram assim consideradas a demolição dos morros e o aterramento das baixadas e alagadiços.

Segundo Marly Motta, na visão de setores políticos, intelectuais e de parte da imprensa brasileira o Morro era considerado o "marco visível da fronteira entre a cidade 'indígena', 'colonial' e 'atrasada', e a cidade 'européia', 'civilizada' e 'moderna' " que se projetava. Sendo assim:

“... a presença do Castelo contrariava um dos pilares mais evidentes dessa vertente de modernização urbana, qual seja, a organização funcional do espaço que condenava a mistura de usos e classes sociais diversos. Edifícios públicos e empresariais não deviam se confundir com barracos; cabras não deviam ouvir ópera. Demandavase uma espacialização da cidade que precisamente definisse os lugares da produção, do consumo, da moradia, da cultura; os espaços dos ricos e dos pobres" (1992: 58-59).

Depois de dois anos de trabalho, uma parte do Castelo foi demolida. Nessa área foram construídos os prédios da Exposição Universal do Centenário, solenemente inaugurada a Sete de Setembro de 1922. A Exposição representava o momento de

\footnotetext{
${ }^{133}$ Conforme referido no primeiro capítulo dessa dissertação, esse foi o momento do "Rio civiliza-se". Destacaram-se, segundo a historiografia e os próprios contemporâneos, as obras de saneamento e embelezamento da cidade promovidas no Governo Pereira Passos (1903-1906). Dentre as medidas instituídas constaram: a destruição dos cortiços e casarões coloniais para se construir a Avenida Central, os bondes foram modernizados com a tração elétrica, a construção de um novo porto e a implementação de um código de posturas urbanas impondo alegados hábitos e costumes civilizados. Conferir, por exemplo, Benchimol, Jaime L. Pereira Passos: um Haussmann tropical. Rio de Janeiro: Secretaria Municipal de Cultura, Turismo e Esportes, 1990. Rocha, Oswaldo Porto. A era das demolições: cidade do Rio de Janeiro, 1870-1920. Rio de Janeiro: Secretaria Municipal de Cultura, 1995. SEVCENKO, Nicolau. A Revolta da Vacina: mentes insanas em corpos rebeldes. São Paulo: Scipione, 1993.
} 
apresentar o país à comunidade internacional. Os turistas deveriam ver, para além dos produtos expostos, a potencialidade do progresso brasileiro.

Tendo em vista as questões explanadas, pode-se perceber que o momento histórico produziu diferentes leituras acerca do significado do centenário. Nesse sentido, o Brasil de 1922 foi inclusivamente pensado na perspectiva da história lusobrasileira, seja por meio das releituras acerca da época colonial, das iniciativas da elite da colónia lusa no Rio de Janeiro e dos eventos promovidos pelo Governo português na celebração.

A elite da colónia lusa no Rio de Janeiro, por meio das suas instituições culturais, dos seus representantes no quadro intelectual e político da época, promoveu um discurso de valorização da herança colonial e de exaltação do trabalho do imigrante português na construção da "nova nação". Nesse contexto, a edição da coleção História da Colonização Portuguesa no Brasil (1921-1924), com o apoio financeiro da colónia, representou um importante contributo no sentido de preservar a memória da herança portuguesa na história do país.

Concebida e dirigida pelo jornalista e historiador português Carlos Malheiro Dias, a obra de grande envergadura tornou-se possível somente por meio da fundação de uma empresa; a Sociedade Editora da História da Colonização Portuguesa do Brasil. Dividiu-se assim as tarefas necessárias ao sucesso da publicação formando-se uma diretoria composta por Carlos Malheiro Dias (direção literária), Albino Sousa Cruz (direção financeira), Roque Gameiro (direção artística) e o conselheiro Ernesto de Vasconcellos (direção cartográfica).

Segundo estudo de Jorge Luís Alves sobre Malheiro Dias e o luso-brasileirismo, a organização dos temas e o corte cronológico da História da Colonização (século XV 1580) tinha como modelo as narrativas das histórias nacionais dos países europeus escritas ao longo do século XIX. As mesmas fundamentavam-se na reunião de vasto documentação, provenientes em sua grande maioria de arquivos públicos. Na obra em questão, a investigação histórica privilegiou tanto a coleta e publicação de corpus documentais como a exaltação das origens do Estado-nação, da expansão marítima e do império ultramarino português (2009: 287). 
Imbuída de uma perspectiva lusocêntrica a publicação defendia que as origens da nação brasileira encontrar-se-iam na colonização portuguesa e na herança colonial apresentada como civilizadora e heroica. Visou-se contudo exaltar a contribuição de Portugal na construção da nação brasileira. Essa linha argumentativa aparece, sobretudo, nos textos de Malheiro Dias, responsável pela organização da coleção, pela introdução dos volumes I e III e por sete capítulos (ALVES, idem: 294).

Em linhas gerais, a visão da empresa colonial portuguesa esboçada na História da Colonização Portuguesa no Brasil:

“[...] recaía no caráter civilizatório dessa colonização e sua ação sobre um território duplamente ameaçador em razão da dominância do meio natural e do indígena. A construção de um 'Portugal americano' teve de ser adaptada às vicissitudes do meio e gerou uma nova nacionalidade. Na perspectiva conservadora da $\mathrm{HCP}^{134}$, os escravos, os portugueses degredados e os indígenas são elementos secundários em relação aos colonos portugueses que fizeram da selva uma pátria" (ALVES, ibid.: 302).

Tendo em vista as questões em debate no contexto das comemorações centenárias, é importante destacar a leitura tecida por Dias na introdução do primeiro volume de HCP, ao propor uma relação presente-passado. O historiador ressaltou, na análise em questão, o contributo do trabalho do imigrante português no Brasil, equiparando os seus esforços ao dos antigos colonizadores e desbravadores do período colonial. Dessa forma, reivindicava o reconhecimento do papel de relevo do imigrante no Brasil do século XX (ALVES, idem, ibid.: 295).

No conjunto de iniciativas que buscaram alimentar a imagem da comunhão luso-brasileira nas celebrações da independência destacaram-se: o vôo Lisboa-Rio de Janeiro e a visita do presidente António José de Almeida.

Com o apoio do governo republicano português, realizou-se a primeira travessia aérea do Atlântico Sul, num vôo Lisboa-Rio, empreendido por Gago Coutinho e Sacadura Cabral. Essa empreitada, narrada em tom de epopeia, visou rememorar e fortalecer os laços entre os dois países.

\footnotetext{
${ }^{134}$ História da Colonização Portuguesa no Brasil.
} 
O feito foi celebrado pela imprensa nos dois lados do Atlântico e teve um papel de relevo, tanto no contexto brasileiro como no português. Em meio às tensões deflagradas pelo nacionalismo radical lusófobo, as repercussões do vôo estimularam toda uma construção simbólica que ressaltava a amizade luso-brasileira e confrontava o discurso anti-português.

Na sociedade portuguesa, o ato considerado heroico, produziu uma espécie de comunhão nacional num momento de grave crise do regime republicano. Uma imagem icónica, produzida no "calor" das celebrações em torno da travessia aérea foi a do "beijo através do Atlântico" entre as duas pátrias, impressa na capa da revista Ilustração Portuguesa. A imagem, carregada de significados simbólicos, transmite pistas dos ecos do feito dos aviadores no período:

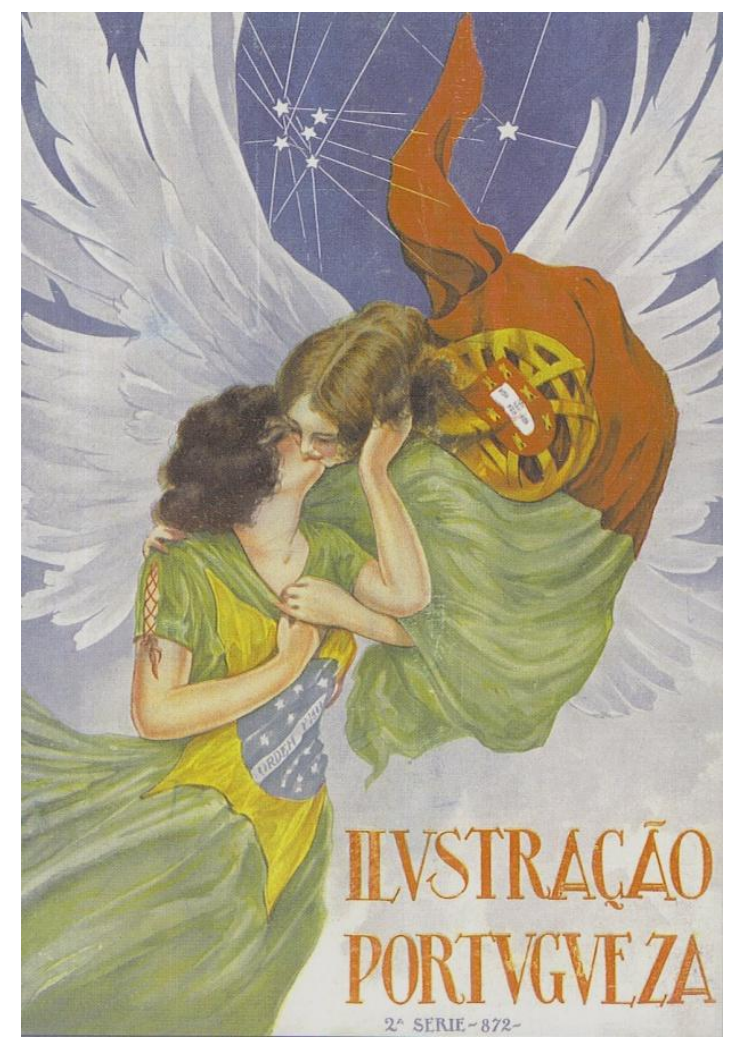

Ilustração Portuguesa, no 872, 4/11/1922.

A viagem do então presidente António José de Almeida ${ }^{135}$ para participar dos festejos da independência produziu também significativo impacto. Era a primeira vez

135 Uma vasta documentação em torno da viagem (discursos, cobertura da imprensa, etc.), desde o
momento do embarque para o Brasil, até o dia do retorno à Portugal encontra-se reunida no livro Duas
Pátrias (1923) do jornalista de O Mundo, Luís Derouet, enviado especialmente para cobrir o evento. Foi, 
que um chefe de Estado português visitava o Brasil, após o processo de independência. A sua estadia, de 17 a 26 de Setembro, foi preenchida por várias solenidades, tais como: banquetes, visita ao Congresso Nacional, receção no Grémio Republicano Português, Exposição Universal do Rio, dentre outras.

O presidente consagrou-se por meio dos seus discursos. Nesse sentido, é interessante analisar qual a visão da relação histórica Portugal-Brasil que sobressaiu desses pronunciamentos. Destacamos, a seguir, um trecho de um dos discursos que consideramos emblemático:

"A emancipação política da grande patria que é hoje o Brasil foi um facto espontaneo e normal, consequencia de uma evolução inexoravel que nenhuma força seria capaz de impedir [...] O Brasil independente de hoje tem pois que agradecer a Portugal o facto de elle lhe ter legado, intacto, à custa de torrentes de sangue e torrente de lágrimas, tamanho e tão rico patrimonio. Mas Portugal tem que agradecer ao Brasil independente de hoje a energia, a bravura, a intelligencia e o amor da raça com que elle tem sustentado, augmentando-a, desenvolvendo-a e doutorando-a de uma maior magestade e belleza, a sua obra, que foi a maior gloria do seu grande passado [...] Brasil e Portugal são duas pátrias irmãs, cada uma vivendo em sua casa, tendo um passado até ha cem annos commum e um futuro, em muitos pontos, diverso, mas, em tantos outros, equivalente" ${ }^{136}$.

Apresentou-se uma leitura de que a emancipação política do Brasil foi parte de um processo "espontâneo". Tratou-se de uma visão conciliadora, que excluía os embates e conflitos ocorridos no processo de independência, no contexto do vintismo português ${ }^{137}$. Um indício de que este processo não teria sido tão linear foi o reconhecimento da independência brasileira por Portugal ter ocorrido somente em

ainda, escrita uma dissertação de mestrado que analisou a viagem presidencial e os seus desdobramentos no contexto do final da I República. Conferir: Marques, Rosália Augusta da Cunha. A Viagem do Presidente António José de Almeida no Âmbito das Relações com o Brasil no Final da I República. Dissertação de Mestrado, Faculdade de Letras, Universidade do Porto, 1998.

${ }^{136}$ Partes do discurso de António José de Almeida no banquete oficial realizado no Catete, Rio de Janeiro, em 18 de Setembro de 1922. In: Discursos do Dr. Antonio José de Almeida (Presidente da Republica Portugueza). Rio de Janeiro: Jacintho Ribeiro dos Santos Editor, 1922, pp. 7-9.

137 Não é nosso objetivo nesse trabalho discorrer sobre o processo de independência, mas analisar algumas leituras acerca do mesmo nos discursos do presidente português. Um estudo interessante sobre este tema é o de Lúcia Maria Bastos P. Neves. "A guerra de penas: os impressos políticos e a independência do Brasil". Revista Tempo: Dossiê - Descobrimentos e Redescobrimentos do Brasil. Niterói: Universidade Federal Fluminense (UFF), vol. 4, №. 8, Dezembro/1999. Disponível em: http://www.historia.uff.br/tempo/artigos_dossie/artg8-3.pdf . 
1925, quando foi assinado o Tratado de Paz e Aliança com o Brasil. Outro elemento marcante no discurso é a ideia do Brasil como criação, "obra" de maior glória do passado português. Reforçava-se, portanto, o mito de que Portugal inventou o Brasil, marginalizando a participação das outras culturas nesse processo.

Em linhas gerais, a oratória buscava despertar um sentimento de nacionalismo luso-brasileiro, expresso na imagem das "duas pátrias-irmãs". A terra brasileira simbolizava tanto a "glória dos portugueses que a inventaram" quanto a dos brasileiros que cultivaram essa herança e engrandeceram-na. Do ponto de vista histórico, realçava uma leitura de continuidade entre o período colonial e a independência, sem afastamentos ou ruturas.

Em meio às discussões e avaliações do passado colonial, as quais permearam esse ano de celebrações, foi publicado Heróis Portugueses no Brasil. Nesse trabalho, João de Barros propunha uma leitura de tributo e de recuperação de marcos heroicos do processo da colonização portuguesa no Brasil.

Segundo Marly Motta, o tom dominante que prevaleceu nas produções e discussões do centenário foi de crítica ao período colonial, embora não se deva desconsiderar as leituras que defenderam o valor da herança portuguesa. Nessa linha interpretativa, podemos citar as apreciações do estudo histórico de referência Capítulos da História Colonial (1907), de Capistrano de Abreu, no qual sobressai uma avaliação de pobreza intelectual, moral e material, inexistência de vida social e incapacidade governativa como legado dos colonizadores ao longo de três séculos de dominação (1992: 19-20).

Visão ainda mais crítica foi divulgada pelos intelectuais que integraram o nacionalismo radical brasileiros, do qual Álvaro Bomílcar da Propaganda Nativista era um dos principais expoentes. O autor tomava como referência o conceito de parasitismo social, cunhado por Manoel Bonfim ${ }^{138}$, para analisar o caráter da colonização portuguesa, considerando os seus efeitos devastadores:

\footnotetext{
${ }^{138}$ Ao tomar por base a premissa biológica-social, Bonfim em América Latina: males de origem (1902) analisou as relações entre colonizador e colonizado enquanto parte de um sistema entre parasita e parasitado. Segundo Ortiz, dois momentos marcariam este parasitismo social na visão de Bonfim: a fase
} 
[...] a nossa independência que nos custou rios de sangue, não a alcançamos contra Inglezes, francezes ou norte-americanos, mas contra portuguezes, contra esses mesmos que nos mantiveram, por trez seculos, alheios a todo e qualquer beneficio civilizador e que ainda hoje tentam enredar-nos num velario de mentiras e hypocrisias, para com um refalsado appelo sentimental, encobrir esta realidade monstruosa e inconcebivel, que é a sua disfarçada tutela, a sua descabida e estranha hegemonia nesta capital, cabeça e coração da Republica, em pleno seculo XX" (BOMílCAR, Gil Blas, no 111, 24/3/1921: 2).

Dentro desse quadro de tensão entre diferentes leituras, João de Barros defensor aguerrido do luso-brasileirismo deixou o seu parecer em Heróis Portugueses no Brasil. Ao fazermos uma síntese do conteúdo dessa obra, pretendemos recuperar a visão do autor acerca da ação colonizadora. Essa questão mostra-se importante para situarmos o pensamento que norteava a sua conceção das relações entre Portugal e Brasil.

Segundo Barros, os heróis e os factos históricos abordados no livro circunscrevem-se a meados do século XVII, por ser considerado como parte da História Portuguesa. Avaliava o autor, que a partir do século XVIII os heróis portugueses batiam-se pela causa da alvorecente nação brasileira. Os mesmos, nessa época, já se encontravam moldados pela vida ardente e múltipla brasileira, embora sem esquecer a Pátria distante.

Nessa perspectiva, o autor referia-se ao poder de assimilação da cultura da outrora colónia lusa. Tal questão poderia ser percebida, por exemplo, no caso dos soldados portugueses que ao serem enviados aos domínios lusos acabavam por estabelecer vínculos afetivos com essas terras, aproximando-se dos valores dos nativos (Heróis Portugueses no Brasil, 1922: 92).

Segundo a leitura de Barros, alguns episódios ocorridos no Brasil colonial dos setecentos, como a Guerra dos Emboabas (1707-1709) e a dos Mascates (1710-1711),

de expansão depredadora do colonialismo (exploração dos metais preciosos, destruição das civilizações autóctones) e a introdução do trabalho escravo, que constituiu a exploração do trabalho alheio pela metrópole. No segundo momento ocorreu a fixação sedentária, com a centralização do poder nas mãos da metrópole colonizadora. Conferir, VAINFAS, Ronaldo. "Colonização, miscigenação e questão racial: notas sobre equívocos e tabus da historiografia brasileira". Revista Tempo, Niterói/RJ, v. 8, pp. 7-22, Ago 1999. 
constituíram-se em conflitos entre brasileiros e portugueses, os quais revelaram os primórdios de uma consciência nacional brasileira.

Ao destacar essa questão na conclusão do estudo, o poeta vai ao encontro de interpretações históricas que tiveram um caráter mais oficial, constituindo um dos lugares de memória das celebrações, isto é, o Livro de Ouro do Centenário da Independência do Brasil"139. Num dos textos que compôs o Livro, denominado "A Propaganda Republicana", de autoria de Júlio do Carmo ${ }^{140}$, a "Revolução dos Mascates" foi apontada como um dos episódios da história do país, no qual já se carregava o sentimento de busca da independência e os ideiais republicanos (Livro de Ouro, 1923: 25).

O primeiro personagem destacado por Barros no compêndio dedicado ao heroísmo português foi Diogo Álvares, o lendário Caramuru, conforme denominação dos indígenas. A vida e as proezas desse, que teria sido um dos primeiros habitantes brancos em terras brasileiras, foi imortalizada no poema épico (1781) de Frei de Santa Rita Durão ${ }^{141}$

Segundo as fontes do período, Caramuru teria sido um importante conciliador entre os nativos e as missões empreendidas pelos primeiros donatários enviados pela Coroa Portuguesa. Foi assim descrito por João de Barros:

"[...] Acostumado aos perigos e às lutas; modesto na alma; sincero no seu amor à Pátria; colonizador inicial daquelas terras bárbaras, agora definitivamente portuguesas, espírito sociável, como sempre mostrou ser; coração generoso, que nenhum preconceito de raça entibiava no seu convívio com a gente alheia, mas que serviu sempre, através de tudo, e espontâneamente, os interêsses do seu país [...]" (Heróis Portugueses no Brasil, op. cit.: 15-16).

A forma como conquistou a confiança das comunidades indígenas nas terras da Bahia, onde se constituíram as primeiras ações de povoamento e colonização do Brasil,

\footnotetext{
${ }^{139}$ Livro de Ouro comemorativo do centenário da independência do Brasil e da Exposição Internacional do Rio de Janeiro. Edição Anuário do Brasil. Rio de Janeiro: Almanak Laemmert, 1923.

${ }^{140}$ Coronel da Guarda Nacional e propagandista da república brasileira.

141 João de Barros foi responsável pela adaptação em prosa desse poema. Em suas palavras, numa linguagem mais acessível ao leitor, procurou-se rememorar "[...] o prodigioso e inteligente esfôrço dos colonizadores lusitanos nas terras de além-mar, e, ao mesmo tempo, as primeiras afirmações da energia brasileira [...]" (1935: 10). Conferir: BARROS, João de. O Caramuru: aventuras prodigiosas de um português colonizador do Brasil. Lisboa: Livraria Sá da Costa, 1935.
} 
mereceu grande destaque. Prestou informações fundamentais sobre a terra e os costumes dos nativos às primeiras autoridades civis portuguesas que chegaram à Bahia, servindo-lhes de intérprete junto aos índios.

Diogo Álvares foi recompensado com mercês e com recomendações de sua pessoa ao rei pelo primeiro governador geral, Tomé de Souza. Foi também elogiado em cartas pelo Padre Manuel da Nóbrega. Segundo diferentes relatos, é provável que Caramuru tenha vivido em núcleos urbanos e indígenas, após o início da colonização sistemática. Os indícios sugerem que o personagem faleceu na Bahia no ano de 1557, embora haja dúvidas quanto a essa data (AMADO, 1998: 3).

Outro vulto recuperado por Barros foi João Ramalho, que auxiliou na fundação da Capitania de São Vicente (São Paulo). Este, como o Caramuru, estabeleceu boas relações com os nativos da região. Casou-se com uma índia da tribo dos Goianazes e deixou numerosos descendentes. Não se deveria, segundo o autor, esquecer a importante contribuição prestada por Ramalho a Martim Afonso de Souza na fundação da Vila de São Vicente, nem o que antes realizara o "esforçado e esperto" personagem ao desbravar a selva ignota e conquistar a amizade dos indígenas (Heróis Portugueses no Brasil: 22).

É interessante ressaltar, que ao dissertar sobre esses dois personagens, reforçava-se uma visão da colonização portuguesa como pacificadora e conciliadora. Nessa parte e ao longo do texto, Barros utilizou como referência o trabalho de Rocha Pombo (1857-1933) ${ }^{142}$, um dos pioneiros da historiografia brasileira. Recorreu, também, para contextualizar a história de São Paulo, a obra Paulística ${ }^{143}$ de Paulo Prado (1869-1943), importante intérprete do Brasil, contemporâneo do poeta. Citou, ainda, a obra coordenada por Carlos Malheiro Dias, História da Colonização no Brasil (1922), a qual foi criticada no período por reforçar uma visão lusocêntrica da História da fundação do país ${ }^{144}$. Observemos a passagem escolhida por João de Barros:

\footnotetext{
${ }^{142}$ A História do Brasil, ilustrada, de Rocha Pombo foi publicada de 1905 a 1917, em X volumes no Rio de Janeiro.

${ }^{143}$ Nesse caso, Barros deve ter consultado os ensaios de Paulo Prado, publicados no jornal o Estado de $S$. Paulo. O livro com o mesmo título foi publicado posteriormente, em 1925.

${ }^{144}$ A esse respeito conferir, por exemplo; Álvaro Bomílcar, "Sobre a 'História da Colonização Portugueza no Brazil', do Sr. Malheiro Dias". In: Gil Blas, no 121, 2/6/1921: 2: "Assim, quando um belletrista da
} 
"[...] João Ramalho tronco da maior parte da nobreza de S. Paulo é o medianeiro entre o português e o aborígene, o fundador da raça mameluca e que o destino, propício aos lusitanos, arrojara ao litoral para inaugurar uma raça e uma nação. A cena teatral em que os portugueses, encurralados na improvisada fortaleza (de S. Vicente) vêem avançar os íncolas coroados de penas, brandindo os arcos e as flechas, e escutam com assombro, partindo da legião inimiga, o idioma da pátria longínqua um lugar que supunham habitado só de feras e Bárbaros é o período embrionário da história do Brasil [...]" (História da Colonização no Brasil, apud BARROS, Heróis Portugueses no Brasil, op. cit.: 25).

Na segunda parte do livro, João de Barros discorreu sobre a bravura e os esforços de Mem de Sá e Estácio de Sá. Ambos comandaram missões (1560-1567) de expulsão dos invasores franceses e enfrentamento dos índios Tamoios na região onde se fundou o Rio de Janeiro. O autor conferiu ênfase ao sucesso da empreitada, a qual teria contribuído para consolidar a obra colonizadora portuguesa:

"[...] Os franceses desistiram enfim da emprêsa arriscada em que se tinham lançado. Submeteram-se quantos não pereceram, ou fugiram. Os índios submeteram-se também. Estava Portugal triunfante. A sua obra de colonização ia agora enraizar-se mais pelo vasto litoral do Brasil, que tinha descoberto e lhe cumpria defender das cobiças e das rapinas alheias" (idem: 42).

No terceiro capítulo, o poeta dissertou sobre os heróis portugueses no Maranhão e na Bahia, durante invasões dos franceses e dos holandeses, no período em que Portugal vivia sob o domínio espanhol.

A parte do território brasileiro, onde se formou o Maranhão, também foi ocupada por franceses. Os mesmos fundaram, pelo ano de 1594 , uma povoação que denominaram de São Luiz. Os invasores teriam se aproveitado da situação de constantes desavenças entre os colonos e os padres em relação aos indígenas, para ali

audacia do Sr. Malheiro Dias, estimulado pela propria phantasia, exaltado pela força do jacobinismo portuguez, que levaram a prosapia de nobres estirpes encommenda por conta da abastada culónia, a 20 - vejam só a força numerica! 20 escriptores lusos, uma 'História da Colonização Portugueza no Brazil', para o fim de redimir o passado das culpas, vicios e mazellas que se lhe atribuem que ainda hoje, em pleno século $\mathrm{XX}$, caracterizam a aç̧ão demolidora e malfazeja dessa atrazada dessa colletividade humana; quando se quer, (com prestigio muitas vezes contestado e de uma não menos contestada collaboração na obra da Independencia) ensinar a doutrina ethnica e politica a esses mestiços, productos de macaco e negra, como lá dizem o Homem de Christo e o estylista da 'Mulata', quando se quer narrar fielmente em pesados volumes de encadernação luxuosa, quando fizeram por nós esses rudes avós que para ca haviam de trazer a celeberrima civilização [...]". 
se instalarem. O povoamento francês prosperou e recebeu incentivo da coroa francesa. Conseguiram, inclusive, conquistar a simpatia dos indígenas da região.

A ameaça de expansão do povoamento francês, colocando em risco a autoridade portuguesa local foi contida pelas tropas comandadas por Jerónimo de Albuquerque. João de Barros assim narrou o seu grande feito:

“[...] Estavam [os franceses] magnificamente fortificados e defendidos, e dispostos a vender cara a vida. Mas, depois de muitas vicissitudes e alternativas, a pertinácia e a coragem de Jerónimo de Albuquerque derrotava-os. Triunfador o herói juntava a seu nome, dizem, o apelido de Maranhão. Bem o merecia o nobre português. A sua intrepidez libertava essa bela região do Brasil da presença dos invasores franceses [...]" (Heróis Portugueses no Brasil, ibidem: 47).

João de Barros destacou, nessa parte, a questão da perda da independência portuguesa acarretando, dentre prejuízos morais, espirituais e materiais, a ausência de liberdade. Somados a esses inconvenientes, havia o facto de ter de compartilhar dos inimigos da Espanha, sobretudo os holandeses.

É nesse contexto de disputa entre Holanda e Espanha, que Barros situou a invasão holandesa na Bahia. A primeira figura a destacar-se nesse embate foi a do então Governador Geral Diogo de Mendonça Furtado, que resistiu até os últimos momentos ao ataque bem planeado dos invasores: "Julgava indigno fugir, tendo mais em conta a honra do que a própria vida... Mas não quis o destino que morresse. A 10 de Maio de 1624, caída a Baía na posse dos holandeses, foi preso e, com êles, os seus companheiros de desesperada luta [...]" (idem, ibidem: 50).

Não tardou, mesmo diante das dificuldades, a organização da resistência ao invasor. Nesse segundo momento, foi o Bispo Marcos Teixeira, que antes havia criado dificuldades na defesa ao ataque dos holandeses, que liderou as ações para recuperar a autonomia local. O momento era de extrema gravidade e, por isso, fazia-se necessário impedir a expansão dos holandeses pela colónia.

O Bispo, segundo Barros, conseguiu alimentar o fervor patriótico. Colonos e indígenas ofereceram-se para engrossar o movimento de ataque ao invasor. Algumas vitórias importantes foram galgadas nesse combate, tal como a desarticulação do 
poder holandês com a morte do Governador Van Dorth. Embora tenha o Bispo morrido um mês após a batalha, a sua liderança e conquistas teriam proporcionado o caminho para a recuperação da autonomia portuguesa.

Os portugueses passaram a contar com a ajuda do contingente de soldados das outras capitanias e também da metrópole. Aflorava o sentimento nacional, aparentemente enfraquecido pela tirania espanhola, em prol da defesa da colónia. Houve um empenho massivo de guerra aos intrusos. Reuniu-se, assim, frota de 26 velas portuguesas, a qual se juntou a armada espanhola para combater os holandeses e recuperar a Bahia.

A vitória das temíveis e articuladas forças holandesas só foi possível num esforço de arregimentação das forças portuguesas e do apoio da população local. $O$ protagonismo na derrota dos holandeses (em Maio de 1625) e a recuperação da Bahia foi conferido ao empenho português por Barros, sendo a ajuda espanhola brevemente mencionada. O poeta elegeu a ideia de uma ação coletiva, mobilizada por um sentimento nacional como o principal motivador da vitória:

[...] tão unânime, tão harmónico, tão geral foi o ataque lusitano ou, melhor, lusitano-baiano que, na história dessa operação militar de vasta envergadura e de tenacidade arrojadíssima não houve, por assim dizer, heróis individuais. O movimento nacional, que permitira levar poderosos auxílios aos baianos, e em que a gente humilde tomara parte decisiva, como que se repetia ali, no seu aspecto de heroísmo colectivo... O povo, que na metrópole fôra a alma do entusiasmo suscitador da organização dos socorros, prosseguia a sua obra nessa grande batalha ultramarina [...] (idem:56).

Nesse contexto, a guerra colonial promovida pelos holandeses voltou-se aos territórios coloniais portugueses e de Castela. No caso dos domínios lusos, a longa guerra ultramarina esteve centrada na conquista do comércio das especiarias asiáticas, no monopólio do comércio esclavagista da África Ocidental e do comércio do açúcar brasileiro (BOXER, 2001: 118).

Na quarta parte do livro, João de Barros dedicou-se a narrar as manobras portuguesas no combate travado, mais uma vez, contra o invasor holandês. Como é sabido, os batavos apossaram-se, alguns anos após o episódio da Bahia, de 
Pernambuco, então próspero produtor de açúcar. Essa foi uma longa batalha, pois a ocupação e o domínio holandês nessas paragens estendeu-se por vinte e quatro anos (1630-1654).

Conforme destacou Barros, esse período não foi de calmaria para os representantes da poderosa Companhia da Índias Ocidentais. Eles tiveram que enfrentar a resistência portuguesa, embora muitas vezes com poucos recursos, em vários momentos.

Apesar do protagonismo de heróis portugueses ao longo dessa guerra, destacando-se nomes como os de Matias de Albuquerque, António de Lima, Pedro Barbosa, Moniz Barreiros, André Vidal de Negreiros, João Fernandes Vieira, dentre outros, houve um importante papel desempenhado pelos líderes locais negros e indígenas. Essa foi uma questão ressaltada pelo poeta, quando afirmou que a resistência aos holandeses, a partir de 1635, não se fez somente pelo ardor patriótico de portugueses de sangue, mas por meio das guerrilhas lideradas por negros como Henrique Dias e índios como António Camarão a frente da sua gente (Heróis Portugueses no Brasil, op. cit.: 67).

Ao seguir essa perspectiva de leitura do período, afirmou Barros, que toda a empreitada de defesa e recuperação do território pernambucano pelos portugueses deveria ser atribuída tanto ao lusos quanto aos brasileiros. Referiu, ainda, outra questão importante no processo ao sustentar que ao longo dessa luta os brasileiros "afirmaram um sentimento de autonomia e uma vontade próprios, e não apenas acatamento às ordens ou incentivos do govêrno português, às vezes hesitante ou falho nas suas resoluções ou políticas" (idem: 73).

É interessante matizar, que ao interpretar esses acontecimentos, Barros conferiu destaque a atuação dos "brasileiros", equiparando-a aos esforços portugueses. Não prevaleceu, nesse caso, um olhar lusocêntrico por parte do autor acerca dessa passagem da história colonial tão cara à (re)visão histórica republicana da 
época. Alguns trabalhos historiográficos do período, elegeram a luta contra os holandeses como um marco de afirmação de um sentimento nacional ${ }^{145}$.

Em texto citado anteriormente, o qual integrou o Livro de Ouro do Centenário da Independência, a luta contra os holandeses foi recuperada com forte sentido de germe da nação ${ }^{146}$. Afirmava Júlio do Carmo, que desde o tempo da invasão holandesa os pernambucanos, somente eles, sem o concurso da metrópole sustentaram com patriotismo a terrível luta contra os invasores. O protagonismo nessa interpretação era atribuído às forças locais, "os pernambucanos", em detrimento do auxílio da metrópole portuguesa:

"A luta que sustentaram os pernambucanos, foi o cadinho formador da altivez desse povo que na escola dos combates, de sacrificios, de heroismo comprehendeu, mais tarde, a necessidade da independencia patria" (Livro de Ouro, 1923: 25).

Na quinta e última parte, Barros tratou dos heróis exploradores do sertão brasileiro. Não bastava aos portugueses colonizar somente o litoral, por isso organizaramse expedições, "as bandeiras", destinadas a explorar o interior a partir do século XVI.

No entanto, somente o século XVII consagrou-se como o século dos bandeirantes. Mais do que lusos, esses homens eram paulistas e mamelucos, isto é, filhos de portugueses e índias. Os exploradores foram mobilizados a enfrentar os riscos e desafios da natureza desconhecida em busca de ouro e pedras preciosas.

Segundo Barros, para além dos metais preciosos, era também objetivo dessas expedições: conhecer melhor a terra, traçar vias de comunicação, saber dos perigos do sertão que pudessem interferir na posse do litoral e fixar núcleos de população nessas áreas mais distantes. $\mathrm{O}$ autor buscou ressaltar o carácter de povoamento desse empreendimento, principal contribuição desses bravos personagens, ao seu ver:

\footnotetext{
${ }^{145}$ Tal interpretação pode ser verificada em Capítulos da História Colonial (1907) de Capistrano de Abreu. Conferir, a esse respeito, estudo historiográfico de SILVA, Rogério Forastieri da. Colônia e Nativismo: a História como "biografia de uma nação". São Paulo: Hucitec, 1997.

146 Dentre a vasta bibliografia sobre o tema nação e nacionalismo, referenciamo-nos em Anderson, Benedict. Comunidades Imaginadas: reflexões sobre a origem e a expansão do nacionalismo. Lisboa: Edições 70, 2012. Hobsbawm, Eric J. Nações e nacionalismo desde 1780. Rio de Janeiro: Paz e Terra, 1991.
} 
"[...] Mas, para a grandeza e prosperidade da nossa colonização, essa febre de riqueza, que a metrópole incendiava e estimulava no ânimo dos portugueses do Brasil, valia mais pela conquista do sertão que assim se ia realizando, do que propriamente pelo ouro encontrado. Êste havia de contribuir para a nossa decadência. Aqueles, alargariam e cimentariam o nosso prestígio no mundo, e preparariam a formação e unidade da vindoura Pátria Brasileira" (Heróis Portugueses no Brasil, op. cit.: 81-82).

O autor não mencionou o facto de que muitas das bandeiras visavam capturar indígenas para vendê-los como escravos, ou mesmo, combater os nativos e os negros reunidos em quilombos ${ }^{147}$. Acerca do enfrentamento em relação aos indígenas referiu indiretamente ao citar passagem de Rocha Pombo: [...] “Agora é, portanto, necessário que o batedor de floresta se sujeite antes de tudo ao papel que se lhe impõe: é preciso escarmentar pela fôrça, pela violência, pelo terror as tribus que se aliam num grande ódio contra a conquista [...] (Rocha Pombo, apud João de Barros, idem: 85-86).

Conforme leitura hegemónica da época, prevaleceu o olhar do colonizador branco no texto de Barros. Um contraponto a essa visão pode ser encontrado nos artigos de Álvaro Bomílcar, publicados na Gil Blas de 1921. Bomílcar teceu apreciações críticas acerca da coletânea dirigida por Malheiro Dias; História da Colonização Portuguesa no Brasil. Afirmava o autor, que a obra em questão apresentava uma versão histórica de enobrecimento da memória da ação colonizadora e chamava a atenção para o facto dos índios e os negros não terem voz própria. Fazia, inclusive, um comentário ofensivo à João de Barros, conforme podemos verificar:

"Comprehende-se que não tendo os indios e os negros historiadores seus, outra história e outros argumentos que não fossem as suas lendas, as suas tradições oraes, os seus cantos cheios de ingenuidade, de pureza e de poesia, ignorantes que eram das letras do alphabeto, vencidos pela superioridade das armas dos rudes boçaes civilizados portuguezes, nada pudessem oppor as mentiras monumentaes com que os deveriam malsinar para sempre os chronistas lusitanos, alguns de moral duvidosa, subservientes e bajuladores como João de Barros" (Gil Blas, no 121, 2/6/1921: 2).

Embora o texto apresente visão marcada pelo nacionalismo radical e idealizada em torno dos negros e dos indígenas, é importante termos em consideração tais

\footnotetext{
${ }^{147}$ Comunidades fundadas por negros que rebelavam-se e fugiam do regime escravocrata.
} 
posicionamentos como recurso de análise das diferentes leituras em tensão no período.

Álvaro Bomílcar, no mesmo artigo, citou como exemplo de reconstrução filosófica-histórica insuspeita da colonização portuguesa os trabalhos do emblemático historiador português Oliveira Martins. É interessante destacar, que o escritor utilizou-se como epígrafe um excerto da História de Portugal de Martins, com o seguinte conteúdo:

"O dominio portuguez adquiriu, logo de começo o caracter duplo, que jamais perdeu, apesar de todas as tentativas posteriores de regularização e de ordem. Era no mar uma anarchia de roubos, em terra uma série de sanguinarias depredações" (MARTINS, apud BOMÍLCAR, idem: 2).

Como é sabido, Oliveira Martins é um importante intérprete da história portuguesa e suas obras influenciaram muitas gerações de pensadores. João de Barros também usou Martins como referência em Heróis Portugueses no Brasil, quando retratou, por exemplo, a invasão holandesa de Pernambuco ${ }^{148}$. Podemos assim depreender, que uma mesma obra pode servir a diferentes propósitos, tendo-se em vista as pré-conceções de cada leitor.

Heróis Portugueses no Brasil, um "livrinho sem pretensões ${ }^{149 "}$ conforme palavras do João de Barros é, portanto, um manual de episódios da colonização portuguesa no Brasil, no qual se buscou reunir factos e vultos desse período da História que reforçaram uma leitura enaltecedora da memória do colonizador. O autor aproximou-se, nesse sentido, da interpretação reproduzida na obra de maior envergadura dirigida por Malheiro Dias; História da Colonização Portuguesa no Brasil, publicada no mesmo ano, da qual foram citadas passagens ${ }^{150}$ pelo poeta.

A título de conclusão das impressões de João de Barros sobre esse período da História, destacam-se as suas palavras:

“[...] Não esqueçamos jamais que os portugueses foram os magníficos, heróicos e gloriosos iniciadores dessa história, desde logo ultrapassando a epopeia das navegações pela sua formidável

\footnotetext{
${ }^{148}$ Conferir Heróis Portugueses no Brasil, op. cit., p. 71.

${ }^{149}$ Heróis Portugueses no Brasil, op. cit., p. 85.

${ }^{150}$ Conferir, Heróis Portugueses no Brasil, op. cit., pp. 24-25.
} 
empresa colonizadora e civilizadora, tentada e realizada no Brasil" (Heróis Portugueses no Brasil, op. cit.: 93)

A discussão acerca das obras publicadas por João de Barros no contexto do Centenário da Independência e os seus diálogos com o dado contexto histórico terá sequência com a apresentação das principais temáticas de Portugual, Terra do Altântico.

\section{III.2. "Portugal, terra do Atlântico": em visita ao Brasil}

Em Portugal, terra do Atlântico (1923), João de Barros atribuiu a esta imagem do país como uma terra voltada para o Atlântico, a melhor fórmula para caracterizar o ressurgimento da alma nacional e a continuidade histórica da civilização lusitana. Conferia à origem étnica lusitana, o principal fator de autonomia e diferenciada evolução da alma portuguesa.

Prestou homenagem à memória de Paulo Barreto, o "João do Rio", em "Um precursor da aproximação luso-brasileira". Companheiro na luta pela aproximação entre os dois países, o escritor foi relembrando no seu devotamento à cultura lusa e aos portugueses humildes do Rio de Janeiro:

"Era esse patriotismo dinâmico que êle queria no seu país e que êle possuía no mais alto grau; era êsse patriotismo de fervorosa e persistente energia que o exaltava tambêm no seu religioso afecto pela Pátria Portuguesa. E foi ensinando e pregrando esse admirável credo - que Paulo Barreto morreu, minutos depois de escrever, na redacção do seu jornal, a sua última crónica, como tantas outras fremente de paixão lusitana [...]" (1923: 129-130).

Dentre os factos significativos para o futuro de Portugal, Barros elegeu a travessia aérea do Atlântico e a viagem do Presidente António José de Almeida ao Brasil (1922). Reafirmava-se, por meio desses acontecimentos, o novo estado de espírito da nação e a sua vocação passada, presente e futura para o mar, porque "o mar foi sempre o personagem mais importante da nossa história" (Bourbon e Menezes apud BARROS, idem: 17).

Segundo Barros, no entanto, não era momento de se deixar cegar pelo esplendor da glória da travessia aérea. Fazia-se necessário aproveitar a oportunidade 
para criar com o Brasil uma situação de mútuo entendimento, económico, comercial, artístico e literário. Dever-se-ia buscar um acordo entre Portugal e Brasil que fosse "perante os outros países, a demonstração efectiva da unidade lusitana, vibrando e vivendo ainda em duas nações independentes e autónomas". O ato magnifico dos aviadores deveria constituir uma base sólida do renascimento português (Portugal, terra do Atlântico, ibidem: 26).

Aos olhos do poeta, o feito dos aviadores evocava o caminho a ser trilhado por Portugal no sentido da expansão Atlântica, "única possível, única imposta pela nossa história e pelas nossas necessidades de futuro". Afirmava Barros:

"[...] Enquanto considerarmos apenas o nosso território europeu corremos realmente muitos riscos de que não nos tomem a sério. Mas no dia em que se verificar que nesse berço estreito vive uma alma tão grande, que soube criar e continua criando novas Lusitanias pela Terra afora, então seremos procurados e respeitados pelas outras nações, e poderemos tratar com elas de igual para igual, como na época áurea dos XV e XVI" (idem, ibid.: 27).

Na avaliação de Barros, o período da participação de Portugal na I Grande Guerra teria, por um curto espaço de tempo, feito ressurgir o sentimento da grandeza moral no país. Caso se tivesse perdido a recordação dessa época de plenitude moral, o feito de Sacadura Cabral e Gago Coutinho teria proporcionado tal ressurgimento. “Porque realizado ou não até ao fim, êle [o vôo] demonstrava a vitalidade da raça e o acordo unanime entre governantes e governados na conquista de uma glória maior para a Pátria" (idem: 30-31).

No capítulo intitulado "Ressurgimento" o poeta atribuiu ao advento da República "a vitória do sentimento optimista sôbre o pessimismo doentio que ameaçava submeter todos e tudo". Havia sido a revolução do 5 de Outubro a expressão política desse ressurgimento de fé. A implantação da república "vinha animada de um ideal de vida, de reorganização nacional, de confiança no futuro, da certeza no esforço e da actividade do povo". Os propagandistas republicanos eram, na sua maioria, homens de ação, envergonhados da inação do seu país (ibidem: 40).

O cenário da república portuguesa no ano em que se deram os dois grandes eventos (a travessia aérea e a viagem presidencial), enunciados por João de Barros 
como significativos para futuro do país, revelou-se conturbado. A situação de decomposição partidária e a afirmação desde o sidonismo de associações políticas de tipo nacionalista de direita, como o Centro Católico, ao lado do fortalecimento do espírito nacionalista podem ter favorecido a escolha do "republicano conciliador" António José de Almeida para a presidência. É bom lembrar que Almeida foi o único presidente da I República a cumprir todo o mandato, apesar dos graves problemas enfrentados no período.

A República que se instaurou pela via radical com o apoio da plebe urbana de Lisboa e da Carbonária será sob a hegemonia dos democráticos de Afonso Costa, entre 1910 e 1917, jacobina, anticlerical e antimonárquica, mas marcadamente conservadora nas outras esferas. De acordo com Fernando Rosas: "A República não toca na base material do conservadorismo, na terra, nos negócios, na propriedade, não nacionaliza, não expropria, deixando-o incólume como oligarquia económico-social” (2004: 37).

Nessa fase, o governo republicano não apresentou propostas significativas no campo das reformas sociais e tampouco no domínio de estratégias de modernização económica. Sendo assim, parte da direita incorporou ao discurso da ordem a reflexão estratégica sobre o desenvolvimento do país. Somente no contexto do pós-guerra surgiram reações que podem ser entendidas como a emergência de uma esquerda republicana. Formulou-se um programa razoavelmente coerente para atender à realidade do país no que se refere às reformas sociais, a instrução pública, às políticas financeiras e da modernização económica (ROSAS, idem: 31-32).

É nesse quadro de organização de uma esquerda republicana, a qual então faria oposição ao projeto antiliberal, anticonstitucional e autoritário das direitas conservadoras que António José de Almeida foi eleito presidente da República.

A eleição de Almeida para a presidência foi representativa da sua imagem de convergência, em meio à instabilidade política acirrada. Os componentes nacionalista e carismático da sua figura contribuíram para tal concordância. Enfim, fora aceito como uma espécie de figura tutelar da República. O sentido nacionalista e de concórdia fundamentaram a base do seu mandato. 
Lembremos que Almeida fez parte desde o início, em 1918, da “Cruzada Nacional Nuno Álvares", postura que conduziria a críticas da esquerda republicana. Esta organização agrupou políticos de diversas vertentes num verdadeiro consenso nacionalista, respaldado no renascimento de cultos e mitos das glórias em torno dos heróis nacionais. Surgiu no contexto do desastre nacional da grande guerra e de desilusões do sidonismo e apoiou-se no nacionalismo e no cultivo do catolicismo mais conservador.

Esse movimento teve um papel importante na oposição da direita católica às forças da esquerda republicana e às instituições da I República. A Cruzada forneceu ainda elementos significativos de fundo simbólico e ideológico que conduziram à ditadura de 1926 e fundamentaram o regime autoritário nacionalista e corporativista do Estado Novo (LEAL, 1998).

É importante acrescentar que a Cruzada ao difundir a exemplaridade de Nuno Álvares Pereira (santo condestável e beato) operou a síntese de duas expressões de messianismo enquanto função simbólica. Conjugou a tradição providencialista católica do "santo" com a tradição laica republicana do "condestável". É, sobretudo, nessa segunda dimensão do culto ao condestável, como expressão do nacionalismo messiânico, que podemos compreender adesão do presidente ao movimento.

Foi, portanto, na complexa e quase inviável possibilidade de convergência que Almeida assentou as suas atitudes como presidente. Insistia na dedicação à causa pública e no espírito de unidade. Embora pertencesse a um partido conservar-se-ia, como convinha a um chefe de Estado, alheio a todas as lutas e paixões; "Era preciso pôr, acima dos interesses de grupo, os interesses da Pátria" (ALMEIDA apud, TORGAL, 2004: 155). Nesse contexto, o presidente avaliava que a crise da economia e das finanças era grande, mas apelava ao otimismo do povo e ao espírito de concórdia e de trabalho.

Nos anos da presidência António José de Almeida se auto-proclamou como defensor da Pátria e da República, para além dos partidos. Em todas as visitas que fez buscou afirmar uma ação de atração e mobilizar uma concentração das forças em volta da restauração da Pátria.

Conforme se verificou, embora buscasse esta tal conciliação vivenciou-se um período de aprofundamento da instabilidade política até o fim da República em 1926. 
Registou-se uma grande decomposição partidária e vários governos. Constituíram-se como entraves para a colaboração almejada no seu mandato os dezassete governos e o agudizamento da estratégia bombista e anarquista.

Foi nesse contexto de crise política que se deu um episódio bastante difícil de ser ultrapassado durante a presidência de Almeida; a Noite Sangrenta de 19 de Outubro de 1921. Este acontecimento representaria o ápice dessa conjuntura alargada de conflitos. Foram assassinados três republicanos históricos (Machado Santos, José Carlos da Maia e António Granjo). O pedido de renúncia esboçado pelo presidente seria suspenso até que a situação tivesse sob controle.

Uma manifestação popular constituída por muitos milhares de cidadãos foram prestar apoio ao presidente nesse momento de tristeza e deceção. Em tal manifestação, uma mulher do povo teria afirmado: "Coitado! Têm-Ihe feito os cabelos todos brancos!". E o jornalista Mayer Garção aproveitou para parafrasear este episódio em uma crónica de 10 de Novembro do mesmo ano: "Coitado! Têm-lhe feito os cabelos brancos! Têm, têm, pobre mulher, que adivinhas nele a própria encarnação da República, que tanto tem sofrido também!" (apud TORGAL, op. cit., 174).

O "triunfo" da travessia aérea Lisboa-Rio e alguns meses depois a visita presidencial ao Brasil foram dois momentos de consagração vivenciados por António de Almeida durante o seu mandato presidencial, segundo impressões da literatura produzida sobre o tema. A viagem do presidente português ao Brasil representava o coroamento das homenagens iniciadas com a travessia aérea Portugal-Brasil, realizada pelos almirante e oficial portugueses; Gago Coutinho e Sacadura Cabral.

Como vimos a situação era de extrema instabilidade política e o presidente ainda esteve por renunciar, após contornar a grave crise do outubrismo. No entanto, mais uma vez desistira por uma razão nacional; a travessia aérea Lisboa-Rio de Janeiro. A primeira travessia aérea do Atlântico Sul teve início em 30 de Março e chegou ao destino final (o Rio de Janeiro) em 17 de Junho de 1922, com várias escalas. O vôo foi concebido com o intuito de reavivar as boas relações entre os dois povos na altura das comemorações do centenário da independência brasileira. 
E assim foi descrito o "espírito" desta travessia na carta enviada por António José de Almeida ao então presidente brasileiro, Epitácio Pessoa:

"Esta viagem realizada pelo ar vai acrescentar uma nova estrofe à epopeia das viagens que os Portugueses outrora levaram a cabo sulcando os mares. O coração da raça aí lhe vai, Senhor Presidente, conduzido pelas mãos de Heróis numa empresa quase sobre-humana. V. Ex. a o receberá sem dúvida com o carinho fraterno que anima as relações das duas grandes pátrias a que temos a honra de presidir, e por isso Ihe ficarei deveras agradecido" (Apud, FRANÇA, 1992: 61).

O vôo seria mesmo uma epopeia, com percalços que levariam a substituição do hidroavião por duas vezes. O primeiro incidente grave ocorreu em 18 de Abril quando houve uma avaria no hidroavião Lusitânia junto aos Rochedos de São Pedro e São Paulo, próximo ao Arquipélago Fernando de Noronha, portanto já em águas brasileiras. Ao saber do acontecido António de Almeida expediu a seguinte mensagem aos aviadores: "Jamais um paladino venceu, com menos honra, uma batalha, em virtude de, durante ela, mudar de cavalo" (apud, TORGAL, op. cit.: 176).

A aventura foi destacada nas primeiras páginas da imprensa portuguesa que enviou repórteres dos jornais; O Século, Diário de Lisboa, O Dia e O Comércio do Porto, a bordo do cruzador República, um dos navios que serviu de orientador e apoio no decorrer da viagem.

O grande feito foi comemorado em todo Portugal. Nas páginas dos jornais, nos filmes realizados, nas poesias e nas letras de fado. O evento mobilizou as diferentes forças sociais produzindo uma construção simbólica em torno do passado glorioso do país retomado pelos novos desbravadores.

O país com graves problemas sociais, políticos e económicos que acirraram a crise do regime republicano, rendia-se à mística dos heróis da era dos quinhentos alimentada pelo sucesso da empreitada aérea:

“[...] 'Sobre a agitação dos acontecimentos e sobre as desgraças da terra', a Pátria era a única palavra 'que não envelhecia', dizia nesse dia o fundo do 'Diário de Lisboa' pondo ao alto do cabeçalho os retratos dos dois heróis e, por baixo, os do Infante D. Henrique, 'precursor de Gago Coutinho', e de Álvares Cabral, 'precursor de Sacadura Cabral'. Em Portugal, de Norte a Sul do País, ao que se disse, repicaram festivamente todos os sinos das igrejas [...]" (FRANÇA, op. cit.: 64). 
Em edição especial para comemorar o êxito da viagem aérea, em 12 de Maio de 1922, a Revista Seara Nova apresentou vários artigos e poesias que comentavam o grande feito dos aviadores.

O periódico expressava as ideias de um grupo de intelectuais republicanos que se atribuiu o papel de renovar a elite intelectual portuguesa. Esses intelectuais traçaram uma estratégia de intervenção política suprapartidária, com o intuito de superar a crise mental, ideológica, política e económica do regime liberal-republicano do início dos anos de 1920 (REIS, 2004).

Pareceu-nos pertinente dedicar uma atenção especial às representações construídas sobre as relações Portugal-Brasil pela Seara Nova. Sobretudo, considerando que a Revista fora concebida como meio para se criar uma opinião pública forte e consciente. $\mathrm{O}$ grupo de intelectuais ${ }^{151}$ portugueses, reunidos em torno da revista, defendia que somente uma opinião pública consciente poderia impor aos políticos o plano de reformas estruturais que a sociedade necessitava. João de Barros também foi colaborador do periódico.

Nas matérias da revista ressaltou-se o valor desses dois portugueses, que empreenderam uma conquista tão nobre quanto a da geração dos ilustres marinheiros dos quinhentos. A partir desse feito, recuperou-se o valor universal dos grandes descobrimentos, com uma nova e genuína contribuição para a humanidade.

O artigo de abertura da revista, assinado por Jaime Cortesão, recebeu o emblemático título de "Os Novos Lusíadas". Essa atribuição nos pareceu bastante representativa da imagem que se criou em torno da travessia. A imagética do heroísmo português de outrora, imortalizado nos versos de Camões, aparecem reelaborados em novos tempos; em tempos "modernos":

"Como os seus antepassados de Quatrocentos, êstes dois homens hão de sentir que o seu acto é dos que de século em século se propagam. Tal qual as navegações dos seus irmãos nas alvoradas do Renascimento, o seu vôo sublime anuncia aos homens uma nova Primavera da Espécie [...] A modéstia e o orgulho, a tenacidade e a disciplina, o método organizador e o espírito de dádiva e sacrifício, o

${ }^{151}$ Raúl Proença, Jaime Cortesão e António Sérgio, dentre outros nomes de destaque no cenário intelectual português da época. 
que mais enalteceu o português das velhas eras, ressurge nos dois como uma aparição de espíritos [...] De novo os olhos portugueses podem chorar as lágrimas sublimes, e os lábios resar, em paráfrases de glória, os versos dos Lusíadas. Mais uma vez na praia ocidental se talham os padrões que delimitam as idades. 'Ó mundo inteiro volta a alumiar-se com a candeia da pequena casa lusitana!'" (Seara Nova, no 13, 12/05/1922: 1).

Gago Coutinho e Sacadura Cabral foram considerados "heróis nacionais". Alguns artigos destacaram o lado da dedicação e dos estudos exaustivos para o sucesso da empreitada. Não era apenas talento, mas dedicação, trabalho, disciplina e pesquisa que poderiam lançar um novo rumo para a situação do país. Os aviadores "não improvisaram [...] colheram os frutos de um labor continuado e pertinente" ${ }^{152}$. Este seria o traço de diferenciação marcante na mensagem do grupo Seara Nova, que apresentava um projeto de renovação das elites intelectuais e políticas portuguesas.

A dialética tradição-modernidade emergia nas páginas dedicadas a esse evento, nas quais se alimentava a memória das grandes navegações que é recriada por meio desta nova empreitada. A Cruz de Cristo nos navios de 1500 e no hidroavião Lusitânia (conforme nos mostra a imagem da capa da revista) simbolizava o encontro dessas duas gerações de heróis e a permanência do catolicismo como valor cultural:

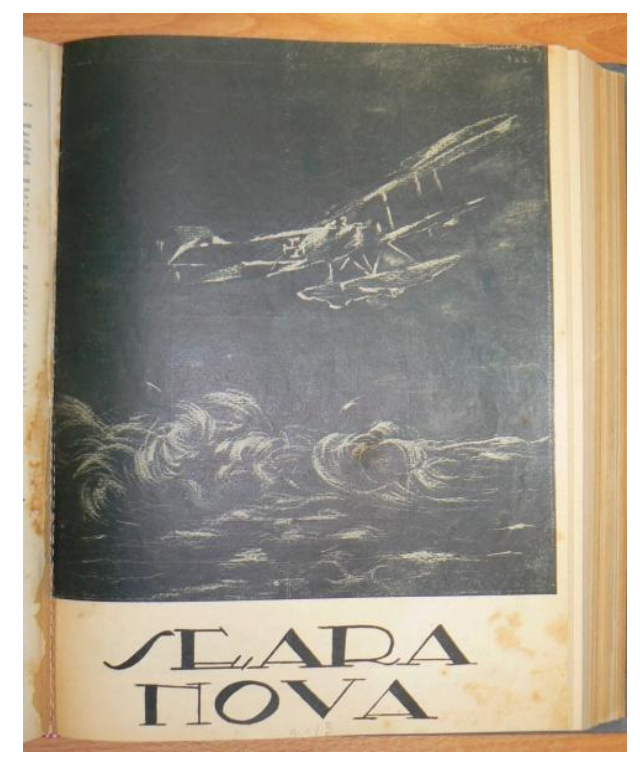

Seara Nova, $\mathrm{n} \cong 13,12 / 5 / 1922$

$\overline{152}$ Sebastião da Costa (colaborador), “A Lição do Lusitânia”, Seara Nova, no 15, 1ㅇ/7/1922, pp. 44-45. 
João de Barros, por sua vez, também fez uma leitura do evento que evocou a relação presente-passado:

"Sacadura Cabral e Gago Coutinho são os continuadores de Pedro Álvares Cabral. Continuadores porque são seus iguais, seus émulos, seus irmãos de patriotismo e de consciência heroica; continuadores sobretudo, porque o seu feito prodigioso liga o Passado ao Futuro, nos portugueses despertando outra vez o sentido de expansão civilizadora, o rácico e tradicional sentido do Atlântico, razão maior da existência da Pátria, fôrça maior da vida da nacionalidade" (1923: 124-125).

As aclamações em torno da travessia não foram uníssonas. A porta-voz do nacionalismo radical brasileiro, a Gil Blas, não se deixou de manifestar. Fustigava a chamada imprensa lusitana do Rio de Janeiro com o título; "A Consagração de um desastre! De Lisboa ao Rio em 80 dias". O artigo dizia que a "patranha" do descobrimento pelos ares não merecia ser denominada de Raid: "Mais depressa faria eu uma viagem num 'tamanco a vela', d'aqui para Portugal, - disse-nos um portuguez desilludido, sympathico aos ideiais nacionalistas" (Gil Blas, no 175, 16/6/1922: 1).

Segundo Luís Reis Torgal, o sentido nacionalista despertado pelos ecos do vôo Lisboa-Rio foi capaz de criar à sua volta um verdadeiro entusiasmo nacional. Era uma espécie de paliativo, com grande valor simbólico, para curar as "doenças" da República. Constituiu-se, ainda, como passo decisivo para o convite feito pelo presidente do Brasil, Epitácio Pessoa, ao presidente António de Almeida para uma visita ao país (2004: 180).

Conforme referido anteriormente, a visita de António de Almeida teve grande repercussão nos meios nacionais. O Brasil no imaginário português era o filho que se emancipou e soube emancipar-se, mantendo unido o imenso território, com muita riqueza a ser explorada.

A base do caráter simbólico encontra-se vinculada à ligação histórica entre os dois países. Deve-se lembrar a importância do Brasil na História portuguesa tanto no passado colonial quanto nas primeiras décadas do século XX. Fora fonte de riquezas e cenário de intensa vivência social com a metrópole e nos anos de 1920 era o principal território a receber um expressivo contingente de emigrantes portugueses. 
A viagem presidencial não se reduzia a uma situação de nível diplomático, mas implicava no reencontro com o tal "filho emancipado" e de sucesso e o "abraço" às populações portuguesas que emigraram para o Brasil. Pode-se ainda acrescentar, o intuito de conquistar o apoio da rica e poderosa colónia portuguesa ao fragilizado regime republicano.

Dentre a comitiva que acompanhou o presidente encontravam-se: João de Barros, então Secretário Geral do Ministério da Instrução Pública; Jaime Cortesão, então Diretor da Biblioteca Nacional; António Luiz Gomes, Reitor Universidade de Coimbra; Francisco António Correia, Diretor do Instituto Superior Técnico; Alfredo Lisboa de Lima, Comissário do governo português na Exposição do Rio de Janeiro; o Vice-Almirante Augusto Neuparth; o General Bernardo de Faria e Silva ${ }^{153}$. Jornalistas, representantes da imprensa portuguesa (Diário de Notícias, O Século, O Mundo e Diário de Lisboa), também acompanharam a comissão.

A viagem foi precedida e acompanhada por problemas. Houve atrasos na saída prevista para 26 de Agosto, mas efetivada somente no dia 28 e, também, no decorrer da viagem. O vapor O Porto, antigo navio mercante alemão, não se encontrava totalmente adaptado para o transporte de passageiros. As avarias no frigorífico do navio obrigaram a paragem para reabastecimento, contribuindo para novos retardamentos (FRANÇA, 1992: 56).

Tendo em vista estes contratempos, não foi possível chegar ao Brasil para as comemorações do centenário da independência, em 7 de Setembro, conforme havia sido planeado. A comitiva presidencial chegou ao Rio de Janeiro somente em 17 de Setembro. Demorou-se o dobro do tempo gasto na época para tal viagem.

António José de Almeida, conforme referido anteriormente, consagrou-se com os seus discursos. A beleza e sentido da sua oratória foram exaltadas pelas imprensas brasileira e portuguesa. O interesse principal dos brasileiros residia na figura de António José, que era popular na colónia portuguesa, e as expectativas foram contempladas. Dessa forma, superou-se em grande parte os comentários em torno do

\footnotetext{
${ }^{153}$ Arquivo Histórico Diplomático do MNE/Lisboa. Cota: 3ㅇ․, A. 18, M. 13 (Viagem ao Brasil do Presidente A. J. A 1922).
} 
atraso da viagem (FRANÇA, op. cit.: 56). Em discurso proferido no Congresso Nacional brasileiro afirmou o presidente:

“ [...] Não tenho duvida em Ihes dizer que estou aqui, em nome de Portugal, para agradecer aos Brasileiros o favor que elles nos prestaram, a nós, proclamando-se independentes no momento que o fizeram. (Muito bem; muito bem! Vivas acclamações!) [...] Se o Brasil se não tivesse proclamado independente na hora em que o fez, que aconteceria, que seria dos senhores, que seria de nós? Que seria dos senhores, retalhados, sujeitos à cobiça de adversarios e inimigos (apoiados; muito bem), que Ihes tomariam conta desta ou daquella parcella, deste ou daquelle trato de terra? (Palmas, acclamações). E que seria de nós, Portuguezes, que, sem podermos, nem devermos conserval-os sob a nossa acção, sob nossa tutella, tudo teriamos perdido aqui: a hospitalidade para os nossos compatriotas, a manutenção de nossas tradições, a continuação do poder da nossa raça (bravos, acclamações) e, mais do que isso, a lingua admiravel que fallamos? (Bravos, muito bem $)^{154}$.

Reforçava-se, mais uma vez, a versão histórica linear e sem tensões do processo de independência brasileira. Sobressaía a imagem da fraternidade lusobrasileira das "pátrias-irmãs", que se buscou valorizar nesta embaixada realizada com pompa e circunstância.

Esses discursos foram bastante emblemáticos e António de Almeida "fez da palavra a arma fundamental", segundo Luís Reis Torgal ${ }^{155}$. As palavras representaram um recurso poderoso que contrastava com a pobreza material, isto é, a escassez de recursos que marcou a viagem. A diminuta velocidade do paquete $O$ Porto de cerca de 10 nós, devido a má qualidade do carvão ${ }^{156}$ e as declarações da primeira-dama, D. Maria Joana Queiroga, de que não teria acompanhado o marido na visita ao Rio, porque não havia dinheiro para que ela se apresentasse condignamente ${ }^{157}$, ilustram bem tal situação.

\footnotetext{
154 Partes do discurso de António José de Almeida no Congresso Nacional, Rio de Janeiro, 20 de Setembro de 1922. In: Discursos do Dr. Antonio José de Almeida (Presidente da Republica Portugueza). Rio de Janeiro: Jacintho Ribeiro dos Santos Editor, 1922, pp. 14-15.

${ }^{155}$ Luís Reis Torgal, op. cit., p. 180.

${ }^{156}$ FRANÇA, José-Augusto, op. cit., p. 56.

${ }^{157}$ Entrevista citada em Luís Reis Torgal, op. cit., p. 37.
} 
Os graves problemas financeiros e políticos da República portuguesa, os quais se refletiram nos atrasos da viagem e na inauguração do Pavilhão Português na Exposição Universal do Rio de Janeiro, parecem não ter abalado a sedução exercida pelos discursos presidenciais. As impressões dos jornais da época corroboram essa ideia:

"Tem havido em Portugal oradores mais castiços mais elegantes mais literários mais académicos do que o sr. António José de Almeida? Não o sei mas o que sei é que nunca houve um orador mais português. Ele representa a nossa raça ele interpreta o sentir do nosso povo não só no seu sentimento sublime na sua intuição maravilhosa mas até nas suas imperfeições..." ( $O$ Mundo, apud VICENTE, 2001: 172).

A imprensa brasileira também teceu considerações elogiosas sobre a oratória do presidente português:

[...] Raras vezes o Parlamento brasileiro podera contar em sua história e felicidade de ter ouvido tão admirável orador, investido de tão alta representação política e social, porque o dr. António José de Almeida é um chefe de Estado que honra o seu glorioso país, que ensoberbece o seu povo, povo de surtos e desprendimentos que não poderia encontrar melhor porta-voz do que o verbo tocante do dr. António José de Almeida [...]" (A Noite, apud VICENTE, idem: 176).

Segundo depoimento do jornalista Derouet, enviado especial do jornal português $O$ Mundo para acompanhar todos os acontecimentos da viagem presidencial, nem mesmo a nativista Gil Blas deixou de saudar António José de Almeida. No trecho citado pelo jornalista anunciava-se as boas vindas ao presidente português, mas não se abandonava o tom crítico lusófobo:

[...] Este panfleto, ainda uma vez, folga em declarar que a sua gloriosa campanha redentora nada tem a ver com a ilustre Nação Portuguesa, com as glórias do seu passado e as fagueiras esperanças do seu porvir. Cabe-lhe, todavia, reafirmar agora - e o faz com a máxima ufania - que jamais abandonará a defesa do Brasil e do brasileiro, preterido em sua terra pela pesada e inconcebível hegemonia do elemento lusitano, que se exerce em nome de uma afectividade mais retumbante do que sincera, fenómeno social verificado não só no comércio e na indústria, como na imprensa política e até nas letras! [...] (Gil Blas, apud DEROUET, 1923: 311). 
Foi a visita de António de Almeida uma embaixada realizada com pompa e com um certo sentido de festa popular, como desejava o presidente que gostava de falar às multidões. $E$, nesse sentido, o discurso mais popular foi feito na Praça da Independência, junto à Exposição Universal, onde se contabilizou, aproximadamente, 300.000 mil pessoas.

Conforme afirmou Luís Torgal, os resultados práticos da visita presidencial foram poucos, prevaleceu o significado simbólico da mensagem da aproximação entre os dois povos, entre as duas "repúblicas-irmãs". Assinou-se uma convenção literária luso-brasileira, um tratado que isentava do serviço militar em caso de dupla nacionalidade e uma convenção sobre a proteção do trabalho dos emigrantes. No entanto, somente a convenção literária foi contemplada na lei portuguesa de $1 \mathfrak{0}$ de Novembro de 1923 (2004: 180).

Era, portanto, com este contexto português que João de Barros dialogava ao escrever Portugal, terra do Atlântico. Afirmava o poeta sentir-se honrado por não ter pertencido a geração que se intitulou de os "vencidos da vida" e sim por fazer parte de uma geração movida por um impulso renovador nos campos da arte, literatura e educação. Geração esta:

"afirmativa, que fazendo amar e compreender os exemplos estimulantes do Passado, quer impelindo para um futuro mais belo a gente admirável da velha Lusitânia [...] E sem a qual talvez não tivesse sido possível a nossa entrada na guerra, nem o comovido respeito e o entusiasmo ansioso que ainda hoje nos traz suspensos do feito heroico de de Gago Coutinho e de Sacadura Cabral" (Portugal, terra do Atlântico, 1923: 41-42).

João de Barros utilizava-se da imagem de uma frase de Herculano; "Isto dá vontade de morrer", para situar um jeito de estar português perante a vida: "Em Portugal parece muitas vezes que todos querem, na realidade estar mortos. Mortos para não sofrerem a inevitável necessidade do esfôrço, da energia, da acção" (idem: 57). Mortos, no sentido de dormentes, para não ter que enfrentar as dificuldades, as complicações e os perigos cotidianos.

Entretanto, afirmava o poeta era preciso desejar estar vivo e vigilante e não adormecido na indolência passiva de uma agonia que se prolonga. Urgia estar atento 
aos desastres que ameaçavam o país, desde a bancarrota até a administração estrangeira. Ao mesmo tempo, ter a consciência de que esses desastres eram evitáveis, "não por meio de revoluções ou sedições, de tumulto ou de gritarias, mas pela energia tenaz, pela serenidade construtiva, pela persistência criadora" (ibidem: 59).

Conclamava os escritores, industriais, comerciantes e artistas, operários e proprietários, ricos e pobres, homens do campo e homens da cidade a salvar Portugal: “Portugal será o que nós formos, o que nós quisermos. Nada mais e nada menos. E nós podemos e devemos salvar Portugal [...] Embora seja, evidentemente, mais fácil deixálo morrer [...]" (idem, ibid.: 61).

No capítulo intitulado "A Pátria Republicana", João de Barros utilizou-se de uma conferência de Ricardo Severo (1869-1940) para fazer as suas observações. Percebe-se que o arqueólogo português ${ }^{158}$ era uma importante referência no pensamento de Barros, sendo citado em outros textos:

"Para Ricardo Severo, como se vê, a República ou é a Nação - ou não é nada. Porque se a nação é, ancestralmente, republicana - a República para ser o futuro, tem de exprimir e afirmar a nacionalidade. Só dessa maneira triunfará. Só dessa maneira permitirá o desenvolvimento do país. Só dessa maneira vencerá os seus inimigos, e dominará as causas da decadência e morte que a monarquia nos legou. Parecem estas verdades correntias ou banais? Não o são, afinal. E ninguém as pensa, ou toda a gente as esquece ..." (Portugal, terra do Atlântico, idem: 78).

Barros contestava a entrevista do escritor Coelho de Carvalho, na qual o mesmo afirmava que dever-se-ia deixar a ideia de que os portugueses descendem diretamente da antiga Lusitânia para as epopeias, operetas e as glosas de fado. Afirmava Carvalho estar de acordo com as descobertas de Ricardo Severo, aceitava, no entanto, "que os lusos tivessem sido uma raça perfeitamente caracterizada [...] mas que êsses lusos tenham vindo até hoje sem mistura e portanto os portugueses sejam uma raça ainda caracterizadamente diferente em absoluto do geral de gente ibérica, é que não acredita [...]" (ibidem: 100).

\footnotetext{
158 Inclusive, o livro Portugal, terra do Atlântico foi dedicado à Ricardo Severo (identificado como Mestre do Patriotismo) e também ao jornalista republicano português Herculano Nunes (1886-1929).
} 
Nessa matéria, compartilhava da visão de Severo ${ }^{159}$, de que a raça lusa, embora misturada com outras, impôs o seu caráter essencial (SEVERO, 1912: 40). Para o poeta era importante considerar a tradição da origem lusitana de Portugal, sobretudo, do ponto de vista da unidade do país num momento de crise nacional. A esse respeito, fez a seguinte consideração:

“[...] Supondo até que essa tradição é puramente imaginária, puramente lendária, completamente inverificável - não é sobre tradições de igual valor que muitos povos e nações teem edificado a sua unidade,a sua independencia, a sua autonomia? E serão esses povos e nações menos progressivos, menos adiantados, menos prósperos do que os outros? Pelo contrário. Uma nação - é já banalidade dizê-lo será tanto mais forte e progressiva quanto mais veemente e firme fôr o sentimento da sua diferenciação, da sua originalidade rácica. Preconceito. É possível..." (idem, ibid.: 102).

Uma outra questão que demonstra a filiação do nacionalismo do nosso poeta remete-se as suas considerações acerca das comemorações de Primeiro de Dezembro, quando celebra-se a restauração da independência política portuguesa (1640) em relação ao domínio espanhol. Barros afirmava que não se conferia o devido valor a esse facto, talvez por ser interpretado como um conjura de fidalgos. No entanto, segundo as interpretações posteriores, verificou-se que a revolução de 1640 teve uma "origem nobremente popular" (Portugal, terra do Atlântico, op. cit.,: 88)

No entanto, segundo o escritor: "A lenda da conjura aristocratica predomina ainda na tradição oral, nas escolas e nos livros de muitos escritores: é ela que geralmente se conhece é ela que todos sabem" (idem: 88). É provável na leitura de Barros, que o comportamento do povo português em relação ao I de Dezembro de 1640 mudaria se percebessem que "a data celebrada comemora não somente a nossa restauração da independência política, mas o regresso do país ao seu destino ancestral, à sua 'missão atlântica', impossível de realizar dentro do sistema continental da política de Madrid" (ibidem: 89).

Nesse sentido, reafirmava a sua crença na leitura de Ricardo Severo: "[...] que dá a Portugal o direito de se considerar como um povo de raça bem caracterizada, navegador e épico, herdeiro de uma civilização já anterior à civilização romana, e 
indomavelmente sequioso da sua liberdade e autonomia". Daí as diferenças com a Espanha. Embora amigos, Portugal e Espanha seriam "heterogéneos de sensibilidade, de feitio e de caráter que nunca poderiam juntar-se na unidade étnica e política de uma só nação e dum só estado" (idem, ibid.: 89-90).

Em relação a aproximação entre Portugal e Espanha, Barros discordava da ideia de alguns profetas ou estadistas portugueses, os quais afirmavam que seria por meio da união com a Espanha que Portugal retomaria os caminhos da europeização. Deverse-ia manter relações cordiais com a Espanha, intensificando-se o intercâmbio literário, artístico, universitário, económico e comercial entre os países vizinhos. No entanto, não seria pelas mãos da Espanha que Portugal integrar-se-ia na Europa. Para além das diferenças históricas entre os dois países, o poeta chamava a atenção para a forma divergente como se posicionaram durante a Guerra. A Espanha manteve-se na condição de neutralidade e numa postura de admiração aos alemães, enquanto que Portugal participou do conflito ao lado da França e da Inglaterra. Nesse contexto, Portugal reforçou os seus laços com a latinidade, ao contrário da Espanha.

Sendo assim, avaliava João de Barros que o prestígio internacional português estaria num bom entendimento com as colónias e com o Brasil. A propósito da língua, da literatura, da arte, dos vinhos tinha-se que continuar a promover uma propaganda inteligentemente nacionalista: "Portugal é Portugal e não pretende senão aproximarse e entender-se com as nações suas limítrofes nas colónias, e com o Brasil, obedecendo dêste modo aos seus interesses e ao imperioso domínio da sua afeição tradicional" (Portugal, terra do Atlântico, op. cit.: 96-97).

A seguir, procuraremos aprofundar mais o contexto dos debates entre as correntes de intelectuais que marcaram os anos de 1920 no Brasil. Destacam-se nesse período as correntes modernistas e as suas discussões em torno da formação da identidade brasileira. Dessa forma, acreditamos oferecer maiores subsídos para situar a leitura proposta por Barros na obra Olavo Bilac e Euclides da Cunha. 


\section{III.3. “Olavo Bilac e Euclides da Cunha": recortes da literatura brasileira}

Na conferência de Abril de 1923, a qual iria fazer parte de uma Antologia LusoBrasileira a ser publicada na Alemanha, João de Barros escolheu discorrer sobre dois escritores-intérpretes do Brasil: Olavo Bilac (1865-1918) e Euclides da Cunha (18661909).

Afirmava o poeta, que a opção por esses dois génios, com perfis literários diferenciados, teve como referência duas características da literatura brasileira: a paixão pela natureza avassaladora do Brasil e a afirmação do espírito sobre essa mesma natureza presentes na obra de Euclides da Cunha; e o complexo de interpretações e de sentimentos que o Brasil recebeu da herança greco-latina, que compunha a escrita de Bilac.

Os dois escritores foram contemporâneos e dedicaram-se a pensar a nação, embora com diferentes perspectivas. No primeiro capítulo dessa dissertação, fizemos considerações acerca de Olavo Bilac e o seu percurso nacionalista, marcadamente no contexto da I Guerra, destacando-se como fundador de A Liga da Defesa Nacional (1916). A poesia e obra de Bilac eram apreciadas nos círculos portugueses da época e o seu nacionalismo reconhecia a importância da tradição cultural portuguesa na formação do Brasil.

Euclides da Cunha, hostil ao cosmopolitismo e ao alvoroço da Belle Époque carioca, encontrava-se em contraposição ao padrão de sociabilidade mais comum vigente no meio intelectual da época. Com essa postura, afastava-se de escritores reconhecidos, tais como Bilac. Publicou, em 1902, uma obra emblemática; Os Sertões, da qual foram citados vários trechos na exposição de Barros. Em linhas gerais, o livro é resultado das observações de Cunha quando trabalhou como repórter enviado pelo jornal O Estado de São Paulo para acompanhar a Guerra de Canudos $^{160}$ (1896-1897), no interior da Bahia.

\footnotetext{
${ }^{160}$ Sertanejos pobres, liderados por Antônio Conselheiro, uniram-se numa cidadela chamada Canudos no interior do Estado da Bahia, nas margens do Rio Vaza Barris, no final do século XIX. Dentre as práticas que desagradavam as autoridades, Conselheiro e seus seguidores negavam-se a pagar impostos, posicionando-se contra leis republicanas, tais como: o casamento civil e o registo de recém nascidos em
} 
Na sua leitura, João de Barros destacava o pioneirismo do autor dos Sertões ao descrever um cenário e suas gentes, até então, desconhecidos daqueles que habitavam as cidades do litoral brasileiro. Sendo assim, afirmava o poeta, Euclides da Cunha "descrevia o que nunca ninguém descrevera e teve de alargar assim a sua expressão até os limites da linguagem, mas sem errar a sua sintaxe, mas sem falsear o seu vocabulário" (Olavo Bilac e Euclides da Cunha, 1923: 39):

Os mulungus rotundos, á borda das cacimbas cheias, estadeiam a purpura das largas flores vermelhas, sem esperar pelas folhas; as carahybas e baraünas altas refrondescem á margem dos ribeirões refertos; íamalham, resoantes, os maryseiros esgalhados, á passagem das virações suaves; assomam, vivazes, amortecendo as truncaduras das quebradas, as quixabeiras de folhas pequeninas e fructos que lembram contas de onyx; mais virentes, adensam-se os icoseiros pelas várzeas, sob o ondular festivo das copas dos ouricurys: ondeiam, moveis, avivando a paizagem, acamadas nos plainos, arredondando as encostas, as moitas floridas do alecrim dos taboleiros, de caules finos e flexíveis; as umburanas perfumam os ares, filtrando-os nas frondes enfolhadas, e - dominando a reviviscencia geral - não já pela altura senão pelo gracioso do porte, os umbuseiros alevantam dous metros sobre o chão, irradiantes em circulo, os galhos numerosos (CUNHA, Os Sertões, 1905: 45-46).

A imagem mítica que Euclides da Cunha projetou do sertão, enquanto elemento de fundação de nacionalidade, imagem do paraíso terreal, berço da nação aproximou-se de uma construção discursiva do romantismo. A essa vertente romântica, somaram-se os valores do cientificismo impressos na obra (R. DE OLIVEIRA, 2002: 514).

Uma outra questão presente na obra do então jovem repórter, consoante ao imaginário da época, era a negação do sertão como parte da conceção da nacionalidade. Sendo assim, a ideia de sertão incorporava a representação do outro

cartórios. Nessa comunidade vigorava uma espécie de mistura entre a doutrina cristã e o misticismo popular. O crescimento do povoado, atingindo aproximadamente 25.000 pessoas, e o posicionamento da população foi percebido como uma ameaça pelas autoridades locais, estaduais e, mais tarde, federais. Foram realizadas quatro expedições militares contra Canudos. A comunidade passou a ser vista como problema nacional pelo governo republicano. Era considerada um reduto de fanáticos, rebeldes e monarquistas numa época em que o regime republicano buscava afirmar-se. Após três campanhas militares, somente a quarta conseguiu vencer os sertanejos, dizimando a população do arraial em Outubro de 1897. A admirável resistência dos seguidores de Conselheiro foi exaltada por Euclides da Cunha nos Sertões. Conferir, por exemplo, COIN, Cristina. A Guerra de Canudos. São Paulo: Scipione, 1995. 
indesejado e distante, simbolizava aquilo que não se poderia conceber como nacional. Euclides da Cunha, como outros jornalistas da época, narrava "para a gente civilizada a vitória da República contra o atraso, a doença e a barbárie". A conceção de nação correspondia aquela propagandeada pelo regime republicano, afastando-se dos símbolos ligados à monarquia (R. DE OLIVEIRA, idem: 516-517).

João de Barros citou várias passagens de Os Sertões, nas quais dava-se destaque à natureza desafiadora daquela região, revelando-se o heroísmo dos sertanejos contra os horrores da seca. O sertanejo era o tipo característico de homem produto da natureza e do meio em que vivia, “[...] e, por isso mesmo, capaz de tornálos seus, bem seus; do homem apto a tôdas as refregas, a todos os sacrificios, a tôdas as persistências" (Olavo Bilac e Euclides da Cunha, op. cit.: 52).

Segundo o nosso poeta, a tenacidade e a resistência da alma do sertanejo destacadas por Euclides da Cunha, o "heroísmo ingénuo" eram características que se encontravam em todos os brasileiros que fizeram o Brasil:

"[...] Heróis como os edificadores das cidades portentosas que, debruçados sôbre as costas brasileiras, chamam o carinho e a admiração do navegante. Heróis como todos êsses que, dia a dia, hora a hora, minuto a minuto, tornam o Brasil uma nação cada vez mais sedutora, mais disciplinada, mais vasta, mais acolhedora" (idem: 53).

Para situarmos melhor a narrativa de Cunha, é importante entendermos que a mesma encontrava-se completamente influenciada pelos pressupostos do cientificismo do período. A estrutura dos Sertões (Terra, o homem e a luta) é pensada segundo o modelo determinista adotado por Taine, o qual concebia o homem como um produto da raça, do meio ambiente e do momento histórico. Na parte em que é abordado o homem, no caso o sertanejo, colocam-se as limitações das teses racialistas da época, presentes na visão do autor, que consideravam o mestiço uma raça inferior (R. DE Oliveira, 2002: 523). Vejamos uma passagem da obra que ilustra essa discussão:

"Alguns firmando preliminarmente, com auctoridade discutível, a funç̧ão secundaria do meio physico e decretando preparatoriamente a extinç̧ão quasi completa do selvicola e a influencia decrescente do africano depois da abolição do trafico, prevêem a victoria final do branco, mais numeroso e mais forte, 
como termo geral de uma serie para o qual tende o mulato, forma cada vez mais diluída do negro, e o caboclo, em que se apagam, mais depressa ainda, os traços característicos do aborígene [...]

Outros vão terra á terra de mais. Exaggeram a influencia do africano, capaz, com effeito, de reagir em muitos pontos contra a absorpção da raça superior. Surge o mulato.- Proclamam-no mais característico typo da nossa sub-categoria ethnica. O assumpto assim vai, derivando multiforme e dúbio. Acreditamos que isto succede porque o escopo essencial destas investigações se tem reduzido á pesquisa de um typo ethnico único, quando ha, certo, muitos. Não temos unidade de raça. Não a teremos, talvez, nunca" (CUNHA, Os Sertões, 1905: 69-70).

A característica mais marcante na literatura de Euclides da Cunha ressaltada por Barros, a qual se mostrou importante na perceção do poeta sobre o Brasil, trata-se do impacto da natureza nos homens e a forma como as populações lidaram com os obstáculos oriundos de tal exuberância e rusticidade. O autor já se havia referido a essa questão na sua primeira obra sobre o Brasil, A Energia Brasileira (1913), analisada no primeiro capítulo dessa dissertação.

É interessante observarmos esse aspecto na narrativa de João de Barros, quando o mesmo discorreu acerca do seu desejo de adentrar numa floresta brasileira, na altura em que visitou uma fazenda de café em São Paulo. Embora sem o aval dos seus acompanhantes que riram da sua ideia, atreveu-se a essa pequena aventura e assim a descreveu:

"[...] dei alguns passos entre as árvores, quinze a vinte, o máximo. Pois foi o bastante para a luz do sol se tornar num crepúsculo saudoso; para que eu deixasse de ver e ouvir os meus companheiros, para que me enterrasse até a cintura no leito fofo das fôlhas sècas; e para que eu tivesse uma impressão de pânico tão grande - é vergonha confessá-lo, mas é verdade - que só então compreendi bem - na minha pequenez e no meu miserável susto - a coragem, a audacia incomparavel dos nossos antepassados que, na ambição de encontrar as minas de esmeraldas, desbravavam as florestas das serras a golpes de machados..." (Olavo Bilac e Euclides da Cunha, 1923: 32).

A paisagem brasileira, segundo Barros, causava uma sensação simultânea de acabrunhamento e de exaltação: “De acabrunhamento pela sua grandiosidade. De exaltação - pela beleza sumptuosa, pela fertilidade do solo, ou pela imensidade dos 
seus componentes, floresta ou rio, baía ou montanha, planície ou altitude" (idem: 3233).

Nesse aspecto, o autor parece incorporar uma tradição que, desde os primórdios da presença europeia em terras americanas, elege o motivo edénico como principal traço na representação do Brasil. A interpretação ícone de exaltação das belezas naturais do país, que influenciou as gerações de intelectuais das quais o nosso poeta fez parte, foi Por que me ufano do meu país ${ }^{161}$ (1900) de Afonso Celso. Observemos um trecho da obra, no qual transparece tal ideia:

“Não é só no Brasil que pompeiam florestas virgens. Há-as magníficas na Ásia e na África. Mas a floresta brasileira se assinala por qualidades especiais.

Em primeiro lugar, as suas madeiras excedem em formosura e duração às melhores do mundo. Abundam nela plantas medicinais e industriais. Inexaurível a sua seiva! Não lhe causa diferença inverno ou verão. Jamais se despem as árvores; guardam o mesmo viço, dão flores e frutos em qualquer época do ano. Vergam ainda ao peso da safra anterior e já rebentam em botões. $O$ agricultor mal the pode vencer a energia invasora. Derriba-se a mata; breve nasce outra mais vigorosa na sede da antiga. Pedras que em toda parte apenas se revestem de musgo ostentam aqui vigoroso arvoredo. Não se notam espaços livres; arbustos rasteiros preenchem os claros. Terra abandonada vê-se logo assaltada pelo mato. Guarnece o chão basto tapete esmeraldino, pontilhado de pequeninas flores. A densidade é estupenda. Avultam as enrediças, os cerrados impenetráveis. A natureza aqui nunca se esgota ou descansa. Em criação incessante e infinita, tira da própria morte, dos troncos caídos, das folhas secas, novos elementos de vida. Os lugares mais pobres têm o encanto dos velhos parques olvidados" (CELSO, [s/d]: 31-32).

Ao introduzir as observações sobre a obra de Olavo Bilac, João de Barros discorreu acerca da unidade brasileira, que "é feita pelo seu espírito, que decerto é uma herança do espírito unificador português, mas que é mantido e engrandecido pelos seus supremos intérpretes, em civismo ou em literatura" (Olavo Bilac e Euclides da Cunha, op. cit.: 54).

\footnotetext{
${ }^{161}$ Obra referida no primeiro capítulo desse trabalho, a qual contribuiu para uma importante vertente nacionalista do período. Segundo a conceção expressa em Por que me ufano do meu país, a nacionalidade é pensada como fruto das prodigiosas condições naturais da terra e não como resultado dos regimes políticos.
} 
Bilac, segundo Barros, civicamente e literariamente era um desses supremos intérpretes do Brasil, que contribuiu sobremaneira para essa mentalidade unificadora. Ao analisar a obra e campanhas cívicas promovidas pelo escritor, depreende-se que a preservação da unidade do país representou uma das suas maiores preocupações.

O poeta brasileiro e seus companheiros parnasianos, no final do século XIX, fortaleceram a ideia de que uma literatura regulada pelo respeito à norma e pela integração do intelectual na vida política e económica da nação constituía um importante requisito na elaboração e manutenção da nacionalidade republicana (FRANCHETTI, 2009 ${ }^{162}$ ).

Aos olhos de Barros, dentre os motivos que levaram Bilac a ser um indicador e condutor da cultura brasileira estava o facto do mesmo possuir uma alma essencialmente mediterrânica:

"E é essa alma mediterrânica - é o prestígio, a graça eterna, a fôrça imorredoira do espírito greco-latino, que no Brasil revive, certo com elementos novos e fôrças novas, mas com a mesma base de medida, de harmonia, de sentimento e de compreensão da vida" (Olavo Bilac e Euclides da Cunha, op. cit.: 55).

Barros lembrou, ainda, a visita do poeta parnasiano à Lisboa, em 1916, onde recebeu muitas homenagens, inclusive da Revista Atlântida ${ }^{163}$. Nessa viagem ao reafirmar o seu apostolado nacionalista, Bilac deixava claro "[...] que o amor do Brasil e de Portugal tão intimamente se conjugavam, numa última saudação à terra dos avós, à terra - berço da língua que êle defendia e honrava" (BARROS, idem: 56).

João de Barros ressaltou o quão importante era o conhecimento da língua nacional na visão de Bilac. Segundo o poeta brasileiro, o idioma constituía a própria nacionalidade:

“[...] A pátria não é a raça, não é o meio, não é o conjuncto dos aparelhos econômicos e políticos: é o idioma creado ou herdado pelo povo. Um povo só começa a perder a sua independência, a sua dignidade, a sua existência autônoma, quando começa a perder o

162 FRANCHETTI, Paulo (2009), “Olavo Bilac e a unidade do Brasil republicano". In: Sibila; http://www.sibila.com.br/index.php/mapa-da-lingua/431-olavo-bilac. Consulta realizada em Novembro de 2013.

${ }^{163}$ Conferir "Revista do Mês", Atlântida, no 6, 1916, pp. 569-603. 
amor do idioma natal. A morte de uma nação começa sempre pelo apodrecimento de sua lingua [...]" (BILAC, 1912: 332).

Tendo em vista esses princípios, Bilac construiu uma defesa apaixonada da Língua Portuguesa e da instrução primária como base da organização social, responsável por conservar e expandir no país o idioma herdado dos portugueses.

Em uma crónica de 1906, "Sobre a Viagem de um Presidente"164, Bilac denunciava a situação da instrução primária na cidade de Blumenau em Santa Catarina. Alertava como sendo o verdadeiro "perigo alemão", o facto do ensino da Língua Portuguesa ter sido relegado a segundo plano, impondo-se as línguas alemã e italiana, conforme os grupos de povoamento instalados na região:

"Não é possível, de certo, imaginar mais deplorável situação. Ao passo que o alemão é ensinado exclusivamente em 81 escolas de Blumenau, e o italiano, também exclusivamente, em 17, sómente ha quatro escolas especialmente destinadas ao ensino exclusivo de Portuguêz! $E$, se juntarmos em grupos as escolas em que as linguas são ensinadas separadamente e cumulativamente, chegaremos a esse desconsolador resultado: nas cento e doze escolas de Blumenau, cidade brasileira, a lingua oficial do Brazil só é praticada (e sabe Deus como!) em oito, ao passo que a lingua polaca é estudada em igual número, a italiana em dezoito e a allemã em noventa!" (Ironia $e$ Piedade, 1916: 47).

Segundo Barros, para o poeta brasileiro impunha-se a necessidade de se formar leitores, aprimorando-se o conhecimento do idioma. Esta seria uma forma de se combater as influências desnacionalizadoras dos emigrantes de outras nacionalidades que não a portuguesa no Brasil. Bilac cantou em versos as glórias de Portugal. Foi paladino da Língua e da tradição lusa, dizia dos portugueses: "Sois o Brasil, porque sois o passado do Brasil" (Bilac, apud BARROS, Olavo Bilac e Euclides da Cunha, op. cit.: 59).

Alguns episódios das biografias de Bilac sugerem que o poeta era bastante admirado e reconhecido pelo público carioca, assim como, a sua escrita tinha considerável penetração popular. No contexto brasileiro dos finais do século XIX, a literatura era cobiçada pelas nascentes classes médias, representando um espaço privilegiado de projeção e debate das ideologias. Com a ascenção da corrente

\footnotetext{
164 "Sobre a Viagem de um Presidente", in: Ironia e Piedade. Rio de Janeiro: Francisco Alves, 1916.
} 
modernista, ocorreu um afastamento na relação entre escritor e leitor (FRANCHETTI, 2009).

Ao propor uma discussão sobre literatura brasileira, Barros concentrou-se nos clássicos de Bilac e Cunha e não fez nenhuma referência aos movimentos literários brasileiros contemporâneos à escrita do livro. Os recortes dos textos dos escritores selecionados pelo autor estabeleciam relações com a herança cultural portuguesa no Brasil. Assim sendo, Bilac foi lembrado nos seus escritos em defesa da Língua Portuguesa e os sertões revelados por Euclides da Cunha remetiam ao desbravamento do interior brasileiro pelos bandeirantes, dentre outras questões.

Nesse sentido, acreditamos que seria importante para situarmos melhor a circulação de ideias da época, marcada por avaliações da herança portuguesa no contexto brasileiro, apresentar um balanço das correntes modernistas do período e suas leituras da nação.

Segundo Marly Motta, ao lançarem-se aos desafios e reflexões que configuraram o centenário de Independência, os intelectuais de 1922 produziram variadas explicações sobre o país, oscilando entre tendências tradicionalistas e vanguardistas. Comprometidos com a construção de um Brasil moderno, as ideias defendidas por esses dois segmentos das elites intelectuais assumiram elaborações bastante diferenciadas (1994: 5).

De um lado temos um grupo de pensadores identificados às ideias das vanguardas europeias da época, dispostos a romper com os cânones clássicos e voltados à realidade nacional, que emergia do ritmo veloz e febril do novo mundo urbano e industrial. Por outro, indivíduos filiados às correntes internacionais de caráter conservador, imersos nos valores da natureza e do campo e avessos ao industrialismo, à dinâmica da vida urbana, litoralista, cosmopolita e liberal (MOTTA, idem: 5).

Para a vertente intelectual vanguardista que integrou as correntes modernistas, destacando-se nomes como Mário de Andrade (1893-1945), Oswald de Andrade (1890-1954) e Menotti del Picchia ${ }^{165}$ (1892-1988), a cidade impunha-se como o novo

165 Jornalista, romancista e político, Del Picchia acabou por assumir uma tendência divergente das ideias
iniciais propugnadas na Semana de Arte Moderna de 1922 e na Revista modernista Klaxon (1922-1923). 
centro dinâmico da vida nacional, constituindo-se como espaço de uma identidade nova. As luzes, os aeroplanos, os motores, as chaminés das fábricas, a velocidade compunham o imaginário moderno. Nessa perspectiva, o tipo representativo da nacionalidade não se encontrava nas matas ou no sertão (MOTTA, ibidem: 7)

O futuro da nação era questionado pelo movimento modernista no processo de mudanças vivenciado pela sociedade brasileira das primeiras décadas do século XX. Tratou-se de um momento complexo, no qual se entrecruzaram dinâmicas diferentes. Havia um contraste entre a industrialização, a urbanização, o crescimento do proletariado e do empresariado e a permanência de aspectos da tradição colonialista, como os latifúndios, o sistema oligárquico e o desenvolvimento desigual das regiões.

No campo da produção intelectual estava em pauta a discussão da redescoberta do Brasil, ou seja, a busca por uma identidade brasileira que refletisse este cenário de mudanças. Alguns eventos e textos foram emblemáticos e deram visibilidade às ideias propagadas pelos modernistas. Destacaram-se nesse sentido, $A$ Semana de Arte Moderna ${ }^{166}$, realizada na São Paulo de 1922, assim como, O manifesto Pau-Brasil (1924) e o Manifesto Antropófago (1928), escritos por Oswald de Andrade, importante expoente da vanguarda modernista.

Num primeiro momento, influenciados pela movimentos artísticos da vanguarda europeia, os portadores das ideias modernistas aderiram ao primitivismo. Uma espécie de promoção culta da barbárie esteve presente nas manifestações dessas

Aliou-se, a partir de 1926, a uma vertente mais conservadora de pensadores, que constituiu o grupo Verde-Amarelo, o qual trataremos mais adiante.

166 Marco simbólico do movimento modernista. A Semana de Arte Moderna realizou-se no Teatro Municipal de São Paulo nos dias 13, 15 e 17 de fevereiro de 1922. A conferência de Graça Aranha intitulada "A emoção estética da arte moderna" abriu o evento. Houve ainda palestras, conferências e discursos de escritores como Ronald de Carvalho, Menotti Del Picchia, Mário de Andrade e Oswald de Andrade. Entre os pintores que participaram da Semana estavam Anita Malfati, Di Cavalcanti, Vicente do Rego Monteiro, Oswaldo Goeldi, John Graz, Zina Aita, Inácio da Costa Ferreira, João Fernando de Almeida Prado, Antônio Paim Vieira e Alberto Martins Ribeiro. Tomaram parte também os escultores Vitor Brecheret, Wilhelm Haerberg e Hildergardo Leão Veloso, e os arquitetos Antônio Garcia Moya e Georg Przyrembel. Dentre os músicos: Villa-Lobos, Guiomar Novaes, Ernani Braga, Frutuoso Viana, Paulina D'Ambrosio, Lucília Villa-Lobos, Alfredo Corazza, Pedro Vieira, Antão Soares, Orlando Frederico e outros coadjuvantes. A dança teve a contribuição de Yvonne Daumierie. Vários outros escritores estiveram presentes, dando apoio aos conferencistas. Entre eles, Guilherme de Almeida, Agenor Barbosa, Plínio Salgado, Cândido Mota Filho, Renato de Almeida, Sérgio Buarque de Holanda, Paulo Prado, Henri Mugnier, Rubens Borba de Morais e Luís Aranha. Conferir: Boaventura, Maria Eugénia. $A$ Semana de Arte Moderna e crítica Contemporânea. http://www.iar.unicamp.br/dap/vanguarda/artigos pdf/maria eugenia.pdf. 
vanguardas europeias, desde o início do século XX. Sendo assim, a escultura da África negra fez parte da génese do cubismo, a poesia primitiva africana transitou entre os expressionistas alemães e os dadaístas de Zurique. Por sua vez, o primitivismo brasileiro foi celebrado na Paris de 1918, que ouviu a execução de dois poemas tupis musicados para vozes femininas e batidas de mãos por Darius Milhaud, o mesmo Milhaud responsável pela partitura de L'Homme et son désir, texto teatral de Paul Claudel ambientado na floresta amazônica e encenado em 1921 pelo Balé Sueco (PAES, 1988: 89).

As inspirações recolhidas na Europa foram reelaboradas e pensadas à luz do contexto sócio-cultural brasileiro da época. A retomada de elementos da cultura primitiva brasileira, os costumes indígenas e africanos, legitimava-se pela sua presença no cotidiano ou como lembranças vivas de um passado recente.

Do ponto de vista literário, ao valorizar a linguagem coloquial e o cotidiano esta nova forma de reflexão decompunha o arcabouço conservador da sociedade brasileira, por meio da ironia e da paródia. Defendia Oswald de Andrade: "A língua sem arcaísmos, sem erudição. Natural e neológica. A contribuição milionária de todos os erros. Como falamos. Como somos" ${ }^{167}$.

Nas celebrações do primeiro centenário da independência política do Brasil, os modernistas ocuparam-se das mazelas culturais remanescentes da herança colonial. Denunciaram a bacharelice, o "lado doutor" da pedagogia jesuíta dominante nas faculdades de Direito. Dispuseram-se contra o "falar difícil" da língua culta, submissa à norma gramatical lusitana. Espelhando-se no cubismo europeu e nas suas proposições acerca das relações entre o primitivo e o popular, os primitivistas brasileiros buscavam renovar radicalmente o código literário (PAES, op. cit.: 91).

Nesse sentido, foi duramente criticada a arte parnasiana, da qual Olavo Bilac destacou-se como grande expoente. Os modernistas propunham deglutir o tom harmonioso, as rimas e os ritmos perfeitos, as citações latinas, o vocabulário erudito e seleto da escrita parnasiana. Como afirmava Mário de Andrade:

\footnotetext{
${ }^{167}$ ANDRADE, Oswald. Manifesto da Poesia Pau-Brasil. In: Do Pau-Brasil à Antropofagia e às Utopias - Obras Completas. Rio de Janeiro: Civilização Brasileira, 1972, p. 6.
} 
"Torna-se lógico que o escrito dos escritores acompanhe a evolução emocional dos surtos humanos. Se no meu foro interior, um velho sentimentalismo racial vibra ainda nas doces cordas alexandrinas de Bilac e Vicente de Carvalho, não posso deixar de reconhecer o direito sagrado das inovações, mesmo quando elas ameaçam espedaçar nas suas mãos hercúleas o ouro argamassado pela idade parnasiana. VAE VICTIS!" (ANDRADE, apud RIBEIRO, 1995: 1011).

Com a expansão dos centros urbanos, gerando um novo complexo de relações, florescem nascentes valores na cultura cotidiana e modificam-se os padrões da comunicação social. As ideias de simultaneidade, concisão, fragmentação, velocidade e arrojo passaram a expressar os tempos modernos.

O Manifesto da Poesia Pau-Brasil ${ }^{168}$ (1924), de autoria de Oswald de Andrade, expressava metaforicamente no próprio título a tentativa dos pensadores modernistas de se libertarem de séculos de sujeição cultural. O Pau-Brasil, produto nativo e primeiro alvo da exploração portuguesa, constituía-se, portanto, no símbolo do produto mais exportado no período colonial. Nesse sentido, a imagem foi apropriada no manifesto com o intuito de valorizar a cultura nativa e, ao mesmo tempo, assinalar a rutura com a dinâmica anterior. Instaurava-se uma nova lógica marcada pela exportação da cultura brasileira ${ }^{169}$.

No Manifesto Antropófago (1928), Oswald de Andrade, assinalava o ápice dessa rutura. O escritor encontrou uma saída original para desvincular a cultura brasileira do domínio da cultura europeia. Embora não se pudesse negar a sua influência histórica, a metáfora da antropofagia subvertia a relação de dependência. Em outras palavras, a ideia de canibalismo operava como uma irónica metáfora que neutralizava a noção de dependência cultural. O canibalismo aqui remetia ao traço principal da cultura brasileira, ou seja, a capacidade infinita de incorporação e reelaboração de elementos de outras culturas:

"[...] Nunca fomos catequizados. Vivemos através de um direito sonâmbulo. Fizemos Cristo nascer na Bahia. Ou em Belém do Pará. Mas nunca admitimos o nascimento da lógica entre nós [...] Contra as sublimações antagônicas. Trazidas nas caravelas [...] A nossa

\footnotetext{
${ }^{168}$ O manifesto foi publicado pela primeira vez no jornal Correio da Manhã, em 18 de março de 1924.

169 FINAZZI-AGRÓ, Ettore. "A Identidade devorada: considerações sobre a Antropofagia". In: CASTRO ROCHA, João Cezar de (org.). Nenhum Brasil Existe. Rio de Janeiro: Topbooks, 2000, pp. 615-626.
} 
independência ainda não foi proclamada. Frase típica de D. João VI: Meu filho, põe a coroa na tua cabeça, antes que alguma aventureiro o faça! Expulsamos a dinastia. É preciso expulsar o espírito bragantino, as ordenações e o rapé de Maria da Fonte" ${ }^{170}$.

Segundo a mensagem do texto era necessário, portanto, digerir os elementos dominantes ainda presentes das culturas estrangeiras na sociedade brasileira, em especial os traços da cultura portuguesa. A proposta antropofágica apregoava o devorar cultural das ideias e dos modelos importados, especialmente dos países europeus, para reelaborá-los com autonomia, visando a produção de algo original.

Buscava-se, então, romper com a relação modelo/cópia que prevalecia na vida cultural do período. A metáfora do canibalismo criada pela corrente modernista inspirava-se no significado da antropofagia no ritual indígena. Por meio desse ato, os aborígenes celebravam o fortalecimento da tribo a partir das virtudes do inimigo derrotado e morto. Era, portanto, o exemplo da oposição, resistência e impassividade do índio diante da invasão colonial (QUEIROZ: 2011: 2-3).

Em confronto com o pensamento da tendência vanguardista dos intelectuais do período, havia um segmento que se identificava com valores mais tradicionais. Herdeiros da visão paradigmática difundida nos Sertões de Euclides da Cunha, de valorização da terra, da natureza e das gentes do sertão essa elite intelectual defendia os valores sólidos da ruralidade.

Para esse grupo, representado por escritores da reação católica como Jackson de Figueiredo (1891-1928) e Tristão de Ataíde ${ }^{171}$ (1893-1983), os Verde-Amarelos Plínio Salgado (1895-1975) e Cassiano Ricardo (1895-1974), ou ainda Monteiro Lobato (1882-1948) e Oliveira Vianna (1883-1951), a identidade nacional deveria ser buscada nos sertões, nos sertanejos, livres dos francesismos do litoral urbano. Membros ou próximos de uma elite agrária em crise, esses escritores filiavam-se às correntes que pregavam um retorno à natureza e a valorização da atividade agrária em detrimento da expansão industrialista (MOTTA, 1992: 35).

\footnotetext{
${ }^{170}$ ANDRADE, O. Do Pau-Brasil à Antropofagia e às Utopias - Obras Completas. Rio de Janeiro: Civilização Brasileira, 1972, pp. 14, 16 e 19.

${ }^{171}$ Pseudónimo adotado pelo escritor Alceu Amoroso Lima.
} 
Os Verde-Amarelos surgiram em decorrência de uma cisão no movimento modernista. Esse grupo ${ }^{172}$ expressava uma vertente mais conservadora dentre as correntes da época. A partir de 1924, denominado segundo tempo modernista, consolidaram-se as diferenças entre as várias correntes do movimento. Inicialmente unidos pela proposta de atualização da cultura e pela crítica aos géneros literários tidos como ultrapassados discordarão, posteriormente, na análise dos caminhos para se modernizar o Brasil. Um ponto central da discussão que acirrou as divergências centrou-se na questão do regionalismo. Seria o regionalismo um sinal de atraso ou o depositário da verdadeira identidade brasileira?

Para o grupo Verde Amarelo, encontrava-se em primeiro plano o culto das tradições brasileiras contra a invasão da cultura alienígena. Daí emergia a importância do regionalismo, pois possibilitava "delimitar fronteiras, ambiente e língua local". Segundo essa visão, só o regionalismo seria capaz de dar sentido real ao tempo e espaço, já que o ritmo da terra é local. Assim, o brasileiro não deveria acompanhar o ritmo da vida universal por ser abstrato e genérico. É este sentido exacerbado do localismo que marca a doutrina dessa corrente, diferenciando-a do ideário modernista (VELLOSO, 1993: 9).

Nessa conceção de regionalismo, São Paulo apresentava-se como o pilar da nacionalidade brasileira. A geografia paulista, caracterizada pelos rios que correm em direção ao interior, estimulou a exploração desse sertão. Dessa forma, ao se embrenharem pelos sertões, os bandeirantes teriam abdicado dos falsos valores do litoral-alienígena para encontrar a autenticidade brasileira, que tem origem no universo rural (VELLOSO, idem: 12).

O modernismo defendido por Oswald e Mário de Andrade não se pronunciou como anti-regionalista, na medida em que conferiu importância ao folclore e aos costumes das diferentes regiões culturais brasileiras, ressaltada sobretudo nos estudos de Mário. No entanto, trata-se de uma outra conceção do regional. Essa visão buscava

\footnotetext{
172 Ao lado de Plínio Salgado e Cassiano Ricardo, também fizeram parte do movimento os escritores; Menotti del Picchia, Cândido Mota Filho e Alfredo Élis. Ricardo, Del Picchia e Mota Filho tornar-se-iam, ao longo dos anos de 1940, ideólogos do Estado Novo Varguista, escrevendo artigos na imprensa diária em defesa das doutrinas do regime.
} 
eleger elementos da cultura brasileira que permitissem mediar a relação regionalismonacionalismo. As diferenças existentes entre as várias regiões brasileiras eram percebidas como partes de uma totalidade corporificada pela nação. Buscava-se extrair do singular os elementos capazes de informar o conjunto. Essa perceção do regional aparece numa das obras ícones do movimento; Macunaíma (1928) de Mário de Andrade (VELLOSO, ibidem: 9)

Tendo em vista as diferentes visões da nacionalidade em disputa, interessa-nos recuperar a leitura histórica desses grupos no tocante à época colonial e suas heranças.

No manifesto Nhengaçu (1929), os Verde-Amarelos rememoravam o período colonial como o momento áureo da civilização brasileira, devido à integração pacífica entre o elemento colonizado e o colonizador. Nessa perspectiva, o encontro inicial entre as culturas indígena e europeia teria sido de colaboração: “

"[...] índios e conquistadores europeus foram aliados na conquista do Brasil: os primeiros abriram o caminho para os que chegaram a seguir (os tupis prepararam 'o ambiente para as entradas no sertão pelos aventureiros brancos desbravadores do oceano'), deixaram-se absorver e mudaram a personalidade lusa, de modo a criar uma mescla de caráter; os segundos, inseriram a 'terra virgem' no cenário mundial" (QUEIROZ, 2011: 11).

A Antropofagia, de Oswald de Andrade, por sua vez, não via pacificidade no encontro entre índios e brancos do início da colonização. Ao contrário, nessa versão os portugueses haviam trazido para o Brasil um empreendimento violento que, por meio do extermínio e da catequização, teria destruído o modo de vida edénico dos indígenas pré-cabralinos: "[...] Antes dos portugueses descobrirem o Brasil, o Brasil tinha descoberto a felicidade. Contra o índio de tocheiro. O índio filho de Maria, afilhado de Catarina de Médicis e genro de D. Antônio de Mariz ${ }^{173}[\ldots] "$.

Nessa leitura, os índios também não teriam agido de forma apaziguadora, mas violentamente contra a invasão dos rivais brancos (QUEIROZ, idem: 11). A imagem

\footnotetext{
${ }^{173}$ Andrade refere-se ao personagem do emblemático livro de José de Alencar, O Guarani (1857), D. Antônio de Mariz na trama era pai de Ceci e, portanto, "sogro" do índio Peri. "Manifesto Antropófago", in: ANDRADE, O. Do Pau-Brasil à Antropofagia e às Utopias - Obras Completas, op. cit., p. 18.
} 
recuperada pela corrente é a do índio canibal Caraíba. Conforme Manifesto Antropófago: "[...] Queremos a Revolução Caraiba. Maior que a Revolução Francesa. A unificação de todas as revoltas eficazes na direção do homem. Sem nós a Europa não teria sequer a sua pobre declaração dos direitos do homem ${ }^{174}[\ldots]^{\prime \prime}$.

Na versão dos Verde-Amarelos, a cultura brasileira é percebida como um campo isento de conflitos, no qual prevalece a integração e a harmonia:

“A Nação é uma resultante de agentes históricos. O índio, o negro, o espadachim, o jesuíta, o tropeiro, o poeta, o fazendeiro, o político, o holandês, o português, o francês, os rios, as montanhas, a mineração, a pecuária, a agricultura, o sol, as léguas imensas, o Cruzeiro do Sul, o café, a literatura francesa, as políticas inglesa e americana, os oito milhões de quilômetros quadrados...

Temos de aceitar todos esses fatores, ou destruir a Nacionalidade, pelo estabelecimento de distinções, pelo desmembramento nuclear da idéia que dela formamos" (Manifesto Nhengaçu, 1929).

Nesse sentido, o grupo indígena tupi é eleito como representante da fundação da nacionalidade brasileira: "Nosso nacionalismo é 'verdamarelo' e tupi", afirmava a corrente no Manifesto Nhengaçu ${ }^{175}$. O tupi simbolizava a passividade e a capacidade de interação étnica-cultural:

"O jesuíta pensou que havia conquistado o tupi, e o tupi é que havia conquistado para si a religião do jesuíta. O português julgou que o tupi deixaria de existir; e o português transformou-se, e ergueu-se com fisionomia de nação nova contra metrópole: porque o tupi venceu dentro da alma e do sangue do português" (Manifesto Nhengaçu, 1929).

O elogio ao tupi era direcionado, sobretudo, a sua capacidade de se fazer existir, não de forma violenta, mas por meio da integração e da fusão dos elementos culturais. Para além de garantir a sua sobrevivência na relação com o português, a característica mais marcante desses nativos encontrava-se no se fazer permanecer, subjetivamente, como traço da cultura brasileira (QUEIROZ, 2011: 11-12).

Segundo Mônica Velloso, no manifesto Nhengaçu, os verde-amarelos rememoravam o período colonial como o momento áureo da civilização brasileira,

\footnotetext{
${ }^{174}$ In: ANDRADE, O. Do Pau-Brasil à Antropofagia e às Utopias - Obras Completas, op. cit., p. 14.

175 "Manifesto Nhengaçu. Manifesto do Verde-Amarelismo, ou da Escola da Anta". Correio Paulistano, 17 de maio de 1929. http://artes.com/sys/artista. php?op=manif\&artid=19.
} 
devido a integração pacífica entre o elemento colonizado e o colonizador. A chegada dos portugueses teria inaugurado um tempo, cuja herança permaneceu ao longo da toda a história do país, tendo em vista a grandeza dos seus valores (VELLOSO, 1993: 10).

Ao recuperar as diferentes conceções defendidas pelas correntes de intelectuais que se propuseram a pensar a nação brasileira e a herança cultural portuguesa nesse processo, esperamos ter estabelecido uma melhor compreensão do contexto histórico em que foram produzidas as obras de João de Barros. Consideramos importante situar os principais debates sobre a relação Brasil-Portugal desenvolvidos por esses personagens que foram interlocutores diretos ou indiretos do poeta português na sua campanha pela aproximação luso-brasileira.

\section{CONCLUSÃO}

O nosso principal objetivo, ao longo desta dissertação, foi dar a conhecer o pensamento de João de Barros enquanto protagonista de uma campanha pela aproximação cultural luso-brasileira. Esperamos, dessa maneira, ter revelado aspectos desta outra face da produção e militância do nosso personagem, brevemente referidas nos estudos sobre o autor.

O percurso do escritor, poeta, pedagogo, homem público e aguerrido republicano ganha sentido no contexto das redes de sociabilidade criadas entre intelectuais portugueses e brasileiros, imbuídos de um ideal luso-brasilista ou lusobrasileirista, nos finais do século XIX e primeiras décadas do XX.

A conceção luso-brasilista apoia-se na tradição de pensamento fundamentada na interpretação lusófila da história e da cultura brasileiras vinculada as estratégias de valorização do legado português numa memória coletiva. Este entendimento da relação cultural Portugal-Brasil mobilizou um conjunto de iniciativas individuais, coletivas e institucionais elaboradas por círculos de intelectuais, nas duas margens do Atlântico, em prol de uma fraternidade luso-brasileira, o qual teve maior difusão nas 
esferas afetivas e culturais. A fundação da Revista Atlântida (1915-1920), por João de Barros e João do Rio, deve ser pensada a luz dessas redes e parcerias em torno do aprofundamento dos vínculos culturais entre Portugal e Brasil.

Rececionado por João do Rio em 1912, quando se deu o primeiro contato de João de Barros com terras brasileiras, mostrou-se contagiado pela chamada "energia" brasileira, que deixava as marcas do poder realizador do trabalho e do esforço humano. O conceito de energia e o sentido de exaltação à vida presente no texto do poeta referenciava-se no ideário do neo-romantismo vitalista português, o qual defendia um literatura de intuitos, com vistas a intervenção na realidade. Em suas poesias, Barros incitava os portugueses a ultrapassar as cantilenas em torno do passado glorioso e inventar um futuro. A partir dessa primeira viagem, o Brasil far-se-ia presente nas obras do poeta enquanto utopia e terra de luz, acenando com um sentido de porvir.

João de Barros dedicou uma boa parte das suas impressões registadas em $A$ Energia Brasileira (1913) à questão do ensino no Brasil da época. Nesse debate discorreu sobre a importância atribuída ao ensino da língua portuguesa e as suas diferenças nas cidades de São Paulo e no Rio de Janeiro. O ensino da língua era visto como fator unificador em meio a um contexto de diferentes fluxos migratórios, como os de origem italiana e alemã. Daí emergia a imagem de um certo afrouxamento nas regras do ensino da língua no Rio de Janeiro, tendo em vista a massiva presença do imigrante português nesta cidade.

Aos olhos de Barros, a colónia portuguesa não era vista como estrangeira. Esta é uma conceção que denota uma visão marcadamente lusófila da sociedade brasileira. Esta imagem vai ao encontro da memória construída pela elite lusa no Rio de Janeiro, por meio de suas instituições culturais, na qual se ressaltava as qualidades do português como "obediente, trabalhador, apolítico", ou seja, um imigrante ideal para a ordem social vigente.

Esta visão conflituava com a perceção dos grupos que representavam o radicalismo radical lusófobo, dedicando-se a combater a influência da elite lusa no 
comércio, na indústria e na imprensa carioca. Nesta leitura prevalecia a visão do imigrante português como "usurpador, bronco, inculto, tacanho".

Uma preocupação que tivemos, ao longo do trabalho, foi a de estabelecer um contraponto ao conceito de luso-brasileirismo, tendo em vista as tensões vivenciadas no contexto brasileiro da época, marcado por manifestações anti-portuguesas. As mesmas ocorreram na disputa entre trabalhadores brasileiros e portugueses num mercado de trabalho urbano em formação e por meio de leituras nativistas. Estas últimas foram elaboradas por um grupo de intelectuais que fundou organizações e publicou obras e revistas para defender as suas ideias. Nesse quadro, destacaram-se nomes como o de Álvaro Bomílcar, Jackson de Figueiredo e Alcebíades Delamare. As revistas criadas por esses intelectuais foram Braziléa (1917-1918) e Gil Blas (19191923). A última, intitulada panfleto de combate, apresentou conteúdos de cariz fortemente lusófobos, com críticas mordazes, tais como: "a chaga purulenta do lusitanismo audaz e cupido $\left.{ }^{176}[\ldots]\right]^{\prime \prime}$.

Os conceitos de raça e meio ambiente foram estruturadores das abordagens nacionalistas e antilusitanas do período. Nessa linha interpretativa, elementos simbólicos como a história, a língua e a religião foram evocados como agentes formadores da identidade nacional brasileira. Tais elementos emergiam nos discursos que questionavam ou afirmavam o papel da cultura portuguesa na formação da identidade brasileira.

João de Barros nas suas obras da Campanha Atlântica, posicionou-se sempre de forma conciliadora quanto às manifestações lusófobas, situando-as como uma questão delimitada a certos grupos e não como representativas do sentimento nacional dos brasileiros em relação aos portugueses. No entanto, uma análise mais aprofundada das correntes nacionalistas do período sugere uma considerável expressão do movimento nativista. Ao lado das correntes do nacionalismo radical, formaram-se organizações nacionalistas reunidas em torno de personalidades literárias como o caso de Olavo Bilac. Estas dedicaram-se a defender uma campanha de patriotismo e civilismo, reconhecendo-se como tributárias da cultura portuguesa.

${ }^{176}$ Gil Blas, 25/9/1919, o 33: 10. 
A criação da Revista Atlântida constituiu um importante contributo na missão desempenhada por João de Barros que, em parceria com João do Rio, mobilizou muita energia neste projeto de cooperação luso-brasileira. Direcionada a um público leitor culto, o mensário investiu numa propaganda republicana, empenhando-se em revivificar Portugal interna e externamente. Atlântida fez da propaganda nacional a base em que definia a ideia da aproximação luso-brasileira.

As reportagens favoráveis à participação de Portugal na guerra, com grande cobertura no periódico, contribuíram para situar o perfil político-ideológico da publicação. No entanto, um dos temas mais marcantes debatidos nas páginas da revista, no tocante a relação Portugal-Brasil foi a proposta de uma confederação entre os dois países. A defesa de uma união política luso-brasileira gerou polémica entre os círculos intelectuais da época, divididos entre entusiastas e opositores a esta ideia. Embora o tema tenha sido abordado de maneira favorável na revista, João de Barros dedicou um capítulo em O Sentido do Atlântico (1921) a questão, no qual afirmou nunca ter apoiado a proposta confederativa.

As revistas A Águia, porta voz da corrente político-filosófica Renascença Portuguesa e a Nação Portuguesa, representante do Integralismo Lusitano, foram chamadas ao debate como contraponto às leituras da Atlântida. Embasadas em referenciais teóricos divergentes e dedicadas a discutir os sentidos da nação, apresentaram perspectivas diferenciadas em torno da relação Portugal-Brasil, sobretudo a Nação Portuguesa. Nas páginas da segunda série d' A Águia as impressões sobre o Brasil surgem na secção "Carta do Brasil", escritas por Álvaro Pinto. O jornalista português tratou de temas como, por exemplo, as condições do imigrante português no Brasil e também do movimento nativista.

Na integralista Nação Portuguesa, a temática luso-brasileira é tratada a partir do conceito de hispanismo defendido por António Sardinha. Segundo esta conceção, buscava-se recuperar um sentimento espiritual de pertença ao denominador comum; a "madre Hispania". Essa unidade remetia ao período dos descobrimentos quando os navegadores espanhóis e portugueses ampliaram os roteiros da civilização e criaram o tipo hispânico. 
O Brasil surge na expansão do conceito de hispanismo. Nesse caso, ao conceito de hispanismo estendido às Américas somava-se o prefixo Pan, reforçando-se assim a ideia de um movimento para além da península ibérica. O Pan-hispanismo é entendido como a união entre Portugal, Espanha e os países "irmãos" da América, como forma de combater a doutrina que pregava a solidariedade política e económica entre os países americanos; o Pan-Americanismo.

Ao recuperarmos as obras produzidas por João de Barros em 1922 e 1923, buscamos situá-las no contexto mais amplo dos debates entre as correntes intelectuais e literárias brasileiras voltadas a repensar a nação que comemorava cem anos de independência. Tratou-se de um momento fértil em produção de releituras sobre a história brasileira e sobre a herança do período colonial. Barros deixou o seu contributo a estas discussões em Heróis Portugueses no Brasil, um manual no qual recuperou os principais vultos da fase inicial da colonização portuguesa no Brasil. A sua interpretação evocou uma memória enaltecedora do colonizador.

Ao fim deste trabalho, esperamos ter conseguido atribuir ao percurso de João de Barros o lugar de destaque que lhe é devido no panorama das discussões sobre as relações culturais luso-brasileiras.

\section{FONTES DOCUMENTAIS E BIBLIOGRAFIA}

\section{Fontes Documentais}

\subsection{Livros}

1.1.1. João de Barros

BARROS, João de. A Energia Brasileira. Porto: Chardron, 1913. . Anciedade. Paris-Lisboa: Livrarias Aillaud e Bertrand, 1913.

Atlântida, 1918.

Caminho da Atlântida: uma campanha luso-brasileira. Lisboa:

A aproximação luso-brasileira e a paz. Lisboa: Livrarias Aillaud e Bertrand, 1919.

Sentido do Atlântico. Lisboa : Livrarias Aillaud e Bertrand, 1921. . Heróis Portugueses no Brasil. Lisboa: Aillaud \& Lelo, 1922. 


\section{Bertrand, 1923.}

Portugal, Terra do Atlântico. Paris; Lisboa: Livrarias Aillaud e . Olavo Bilac e Euclides da Cunha. Porto: Livraria Chardron, 1923.

- O Povo na Literatura Portuguesa. Lisboa: Soc. de Instrução e Beneficência "A Voz do Operário", 1931.

. Pátria Esquecida. Lisboa: Imprensa Portugal-Brasil, 1935.

Brasil. Lisboa: Sá da Costa, 1935.

. O Caramuru: aventuras prodigiosas dum português colonizador do . Palavras ao Brasil: discursos. Rio de Janeiro: A Noite Editora, 1936.
. Alma do Brasil. Rio de Janeiro: A Noite Editora, 1937.
Lisboa: Cosmos, 1941.
. Pequena História da Poesia Portuguesa: esboço da sua evolução. . Presenças Eternas. Lisboa: Sá da Costa, 1943.
Dois Mundos, 1946.
. Presença do Brasil: páginas escolhidas, 1912-1946. Lisboa, Edições - Hoje, Ontem, Amanhã...: ensaios e esquemas. Lisboa: Livraria Clássica Editora, 1950. . Adeus ao Brasil. Lisboa: Livros do Brasil, 1961.

\subsubsection{Outros livros}

ANDRADE, Oswald de. Do Pau-Brasil à Antropofagia e às Utopias - Obras Completas. Rio de Janeiro: Civilização Brasileira, 1972.

ARANHA, Graça. Espírito Moderno. São Paulo: Cia. Gráfico Editora Monteiro Lobato, 1925.

AZEVEdo, Manuela de. Cartas Políticas a João de Barros. Lisboa: Imprensa Nacional Casa das Moedas, 1982.

BILAC, Olavo. Conferências Literárias. Rio de Janeiro: Francisco Alves, [online], 1912. http://www.brasiliana.usp.br/bbd/handle/1918/00290800\#page/317/mode/1up .

http://www.brasiliana.usp.br/bbd/handle/1918/00291300\#page/1/mode/1up. . Ironia e Piedade. Rio de Janeiro: Francisco Alves, [online], 1916.

Nacional, A 1917. http://www.brasiliana.usp.br/bbd/handle/1918/00291000\#page/5/mode/1up .

BOMÍLCAR, Álvaro. O preconceito de raças no Brasil. Rio de Janeiro: Typ. Aurora, 1916. - A politica no Brazil ou o nacionalismo radical: ensaio de critica social e histórica. Rio de Janeiro : Leite Ribeiro e Maurillo, 1920. 
CARVALHO, Elysio de. Os Bastiões da Nacionalidade. Rio de Janeiro: Annuário do Brasil; Lisboa: Seara Nova; Porto: Renascença Portuguesa, 1922.

CASTRO, Vitório de. Brasileiros e portugueses. Rio de Janeiro: Teixeira \& Cia.,1925.

CELSO, Afonso. Por que me ufano do meu país. Rio de Janeiro: H. Garnier LivreiroEditor, 1a ed. 1900, 4a ed. [online], [s.d.]. http://www.brasiliana.usp.br/bbd/bitstream/handle/1918/02173000/021730 COM PLETO.pdf.

CHÉRADAME, André. O Plano Pangermanista Desmascarado. Rio de Janeiro/Paris: Livraria Garnier, 1917.

CUNHA, Euclides da. Os Sertões (Campanha de Canudos). 3a ed. corrigida, Rio de $\begin{array}{lllll}\text { Janeiro: } \quad \text { Laemmert } & \text { C } & \text { C., }\end{array}$ http://www.brasiliana.usp.br/bbd/handle/1918/00451800\#page/1/mode/1up .

DEROUET, Luís. Duas Pátrias: a viagem triunfal do Presidente da República Portuguesa ao Brasil. Lisboa: O Mundo, 1923.

JUNQUEIRO, Guerra. Prosas Dispersas. Porto: Chardron, 1921.

MEDEIROS E ALBUQUERQUE. "A Confederação Luso-brasileira”. In: Graves e Fúteis. Rio de Janeiro: Livraria Editora Leite Ribeiro, 1922, 271-276.

MELO, Aldo de Cavalcanti. A Confederação Luso-Brasileira: Esboço de construção jurídica. Funchal: Tipografia do "Diário de Notícias", 1919.

OLIVEIRA. Alberto de. Na Outra banda de Portugal: quatro anos no Rio de Janeiro. Lisboa: Portugal-Brasil; Rio de Janeiro: Companhia Editora Americana: Livraria Francisco Alves, 1919.

PINTO, Manuel de Sousa. Terra moça: impressões brasileira. Porto: Chardron, 1910.

RIO, João do. Alma Encantadora das Ruas. Rio de Janeiro;Paris: Garnier, 1910.

Portugal d'Agora: Lisboa-Porto, notas de viagem, impressões. Rio de Janeiro;Paris: H. Garnier; Livreiro-Editor, 1911.

RODRIGUES, Bettencourt. Uma Confederação Luso-Brasileira: factos, opiniões e alvitres. Lisboa: Livraria Clássica Editora, 1923.

ROMANO, Raul. Veneno! Resposta às Razões da Inconfidência. São Paulo: Livraria Zenith, 1925.

ROMERO, Sílvio. O Elemento Português no Brasil: Conferência. Lisboa: Tipografia da Companhia Nacional Editora, 1902.

TORRES, Antônio. As Razões da Inconfidência. Rio de Janeiro: A. J. Castilho, 1925.

SEVERO, Ricardo. Origens da Nacionalidade Portuguesa. Lisboa: A.M. Teixeira, 1912.

VELLOSO, Duarte. A Confederação Luso-Brasileira (Conferência). Curitiba: Impressora Paranaense, 1918. 


\subsection{Revistas}

A Águia: revista quinzenal ilustarada de literatura e crítica. Dir. e propr. Álvaro Pinto S. 1, a. 1 (Dez. 1910) - a. 20, no 3 (Maio/Jul. 1932) - Porto: Tércio de Miranda, 1912; 1920-1921. Disponível em: http://purl.pt/12152.

Atlântida: mensário artístico, literário e social para Portugal e Brasil. Dir. João do Rio, João de Barros, ed. Pedro Bordallo Pinheiro. Lisboa, A. 1, no 1 (15 Nov. 1915) - A. 5, v. 12, no 48 (1920). Lisboa, 1915-1917; 1919, Disponível em: http://hemerotecadigital.cm-lisboa.pt/OBRAS/Atlantida/Atlantida.htm .

Brazilea: revista mensal de sociologia, arte e crítica. Dir. Álvaro Bomílcar. Rio de Janeiro, 1917-1918. Disponível na Fundação Biblioteca Nacional do Rio de Janeiro.

Gil Blas: panfleto de combate. Dir. Alcebíades Delamare. Rio de Janeiro, 1919-1923. Disponível na Fundação Biblioteca Nacional do Rio de Janeiro.

Ilustração Portuguesa, ed. lit. José Joubert Chaves, a. 1, no 1 (9 Nov. 1903) - a. 3, no 119 (12 Fev. 1906), s. 2, no 932 (29 Dez. 1923). Lisboa: Empresa do Jornal O Século, 1922.

Nação Portuguesa: revista de filosofia política. Dir. Alberto Monsaraz, António Sardinha, Ano I, no 1, 1914. A. 1, no 1 (8 Abr. 1914) - v. 11, no 6 (1938). Coimbra: França \& Armenio, 1914; 1922-1923. Disponível na Biblioteca Museu República e Resistência (Cidade Universitária). Disponível em: http://hemerotecadigital.cmlisboa.pt/OBRAS/IlustracaoPort/llustracaoPortuguesa.htm .

Seara Nova: revista quinzenal de doutrina e crítica. Dir. Raúl Proença, no 1 (15 out. 1921) - . Lisboa: Seara Nova, 1922. Acervo Biblioteca Nacional de Portugal.

\subsection{Cartas à João de Barros}

Espólio João de Barros (1881-1960). Biblioteca Nacional de Portugal.

\subsection{Publicações centenário (1922) e manifestos}

Carlos Malheiro Dias (org.). História da Colonização Portuguesa do Brasil. Rio de Janeiro: Lit. Ferreira Pinto, 1921.

Discursos do Dr. Antonio José de Almeida (Presidente da Republica Portugueza). Rio de Janeiro: Jacintho Ribeiro dos Santos Editor, 1922.

Livro de Ouro comemorativo do centenário da independência do Brasil e da Exposição Internacional do Rio de Janeiro. Edição Anuário do Brasil. Rio de Janeiro: Almanak Laemmert, 1923.

“Manifesto da Poesia Pau Brasil", Correio da Manhã, 18/3/1924.

“Manifesto Antropófago", Revista de Antropofagia, Ano I, N I, Maio de 1928.

Manifesto Nhengaçu. "Manifesto do Verde-Amarelismo, ou da Escola da Anta". Correio Paulistano, 17/5/1929. 


\section{Bibliografia}

ALMEIDA, Cristiane D’Avila Lyra. João do Rio a caminho da Atlântida: por uma aproximação luso-brasileira. Tese de doutorado, Programa de Pós-Graduação em Letras da Pontifícia Universidade Católica do Rio de Janeiro (PUC/RJ), 2010.

ALVES, Jorge Luís dos Santos. Imigração e xenofobia nas relações luso-brasileiras (1890-1930). Dissertação de mestrado, Universidade do Estado do Rio de Janeiro (UERJ), 1999.

Malheiro Dias e o luso-brasileirismo -Um estudo de caso das relações culturais Brasil - Portugal. Tese de doutorado, Programa de PósGraduação em História, Universidade do Estado do Rio de Janeiro (UERJ), 2009.

AMADO, Janaína. Diogo Álvares, o Caramuru, e a fundação mítica do Brasil, [online], 1998. http://folk.uio.no/steisat/Tekster/Amado\%20Caramuru\%20portugisisk.pdf .

ANDERSON, Benedict. Comunidades Imaginadas: reflexões sobre a origem $e$ a expansão do nacionalismo. Lisboa: Edições 70, 2012.

ARAÚJO, Alberto Filipe de, ARAÚJO, Joaquim Machado de. João de Barros: 1881-1960, vida, obra e pensamento. Porto: Estratégias Criativas, 2004.

ARCHER CARVALHO, Paulo. Nação e Nacionalismo: Mitemas do Integralismo Lusitano. Dissertação de Mestrado em História Contemporânea de Portugal, Faculdade de Letras da Universidade de Coimbra, 1993.

AZEVedo, Manuela de. Cartas Políticas a João de Barros. Lisboa: Imprensa Nacional Casa das Moedas, 1982.

BAGGIO, Kátia Gerab. "Os Intelectuais Brasileiros e o Pan-Americanismo: A Revista Americana (1909-1919)" In: Anais Eletrônicos do IV Encontro da ANPHLAC, Salvador, $2000 . \quad$ Disponível em: http://www.anphlac.org/periodicos/anais/encontro4/katia baggio.pdf .

BARIANI, Edison. O Estado Demiurgo: Alberto Torres e a construção nacional. Caderno $\mathrm{CRH}$, vol. 20, no. 49, Salvador Jan./Apr. 2007. Disponível em: http://www.scielo.br/scielo.php?pid=S0103-49792007000100013\&script=sci_arttext .

BARREIRA, Cecília. "Três nótulas sobre o Integralismo Lusitano (evolução, descontinuidade, ideologia nas páginas da Nação Portuguesa, 1914-1926)", Análise Social, vol. XVIII (72-73-74), 1982-3. ․․․-․, 1421-1429. Disponível em: http://analisesocial.ics.ul.pt/documentos/1223461323N1/BL3vp7Vz81PH1.pdf .

BENCHIMOL, Jaime L. Pereira Passos: um Haussmann tropical. Rio de Janeiro: Secretaria Municipal de Cultura, Turismo e Esportes, 1990.

BETHEL, Leslie (org.). História da América Latina, São Paulo, EDUSP/Imprensa Oficial do Estado, Brasília: FUNAG, 2001, vol. III.

BOXER, C. R. O Império Marítimo Português, 1415-1825. Lisboa: Edições 70, 2001. 
BUENO, Luís. "Tamancófilos e tamancófobos de 1925". Revista Letras, Curitiba, n. 59, p. 93-101, jan./jun. 2003. Editora UFPR. Disponível em: http://www.letras.ufpr.br/documentos/pdf revistas/bueno59.pdf .

CAMEIRÃO, Lurdes. Teixeira de Pascoaes e o projecto cultural da "Renascença Portuguesa". Bragança: Instituto Politécnico de Bragança, 2000.

CAMILOTTI, Virginia Célia. Figurações de Brasil na "literatura de intuitos" portuguesa. In: LASA s XXX International Congress - LASA 2012 Toward a Third Century of Independence in Latin America - San Francisco CA/maio 23-26/2012, 2012, San Francisco - CA. LASA2012 Congress Paper Archive. San Francisco - CA: Latin American Studies Association, 2012. . Imagens de Brasil na "Literatura de Intuitos" portuguesa. Convergência Lusíada, n. 29, janeiro - junho de 2013, pp. 205-215. Disponível em: http://www.realgabinete.com.br/revistaconvergencia/pdf/2407.pdf .

CARVALHO, José Murilo de. "O Motivo Edênico no Imaginário Social Brasileiro". Rev. Brasileira de Ciências Sociais, [online]. 1998, vol. 13, no 38, ISSN 0102-6909. http://dx.doi.org/10.1590/S0102-69091998000300004 . . Os Bestializados: o Rio de Janeiro e a República que não foi. São Paulo: Cia. das Letras, 2006.

CASTRO, Zília Osório de. "Do Carisma do Atlântico ao sonho da Atlantida”, pp. 58-87. In: Lucia Maria Paschoal Guimarães (org.)... [et al.], Afinidades Atlânticas: impasses, quimeras e confluências nas relações luso-brasileiras. Rio de Janeiro: Quartet, 2009.

CATROGA, Fernando. Da Historigrafia à Memória Histórica. In: TORGAL, MENDES e CATROGA, História da História em Portugal Séculos XIX e XX. Lisboa: Temas e Debates, 2o vol., 1998.

CHALHOUB, Sidney. Trabalho, Lar e Botequim: o cotidiano dos trabalhadores no Rio de Janeiro da belle époque. 2 ed. Campinas; São Paulo: Editora da Unicamp, 2001.

CHARTIER, Roger. A História Cultural: entre práticas e representações. Lisboa: Difel, 2002.

CHÉRADAME, André. O Plano Pangermanista Desmascarado. Rio de Janeiro/Paris: Livraria Garnier, 1917.

COIN, Cristina. A Guerra de Canudos. São Paulo: Scipione, 1995.

CONCEIÇÃO, Cecília Dias de C. H. da. A Revista Atlântida: documento sócio-cultural e literário de uma época, um abraço mental entre Portugal e Brasil. Dissertação de Mestrado (Literaturas Comparadas Portuguesa e Francesa, sécs. XIX e XX), FCSH/UNL, 1997.

CORRÊA DA SILVA, Maria Isabel. Espelho Fraterno: o Brasil no discurso do republicanismo português:(c.1889-c.1914). Tese de doutoramento em História, Universidade de Lisboa, ISCTE - Instituto Universitário de Lisboa, Universidade Católica Portuguesa, 2012.

COSTA PINTO, António. Os Camisas Azuis: ideologias, elites e movimentos fascistas em Portugal, 1914-1945. Lisboa: Editorial Estampa, 1994. 
CUNHA, Norberto Ferreira da. "A Gênese da Renascença Portuguesa perante a Crise Política e Moral da I República", in: Campos Matos (coord.). Crises em Portugal nos Séculos XIX e XX. Centro de História da Universidade de Lisboa, 2002.

DIMAS, Antônio. Tempos Eufóricos: análise da revista Kosmos, 1904-1909. São Paulo: Ática, 1983.

ESTEVES DE OLIVEIRA, Clementina Maria. O Positivismo e o Ideário Educativo de João de Barros. Porto: Publismai, 2001.

FRANÇA, José-Augusto. Os Anos Vinte em Portugal. Lisboa: Editorial Presença, 1992.

FRANCHETTI, Paulo, "Olavo Bilac e a unidade do Brasil republicano". Sibila [online], 5 de Abril de 2009. http://sibila.com.br/mapa-da-lingua/olavo-bilac/2736.

FERNANDES, Rogério. João de Barros educador republicano. Lisboa: Livros Horizonte, 1960.

FERREIRA, Arminda E. O Luso-Brasileirismo na Perspectiva de Nuno Simões. Esboço de um estudo de natureza Biográfica. Vila Nova de Famalicão: Edições Quasi, 2005.

FINAZZI-AGRÓ, Ettore. "A Identidade devorada: considerações sobre a Antropofagia". In: CASTRO ROCHA, João Cezar de (org.). Nenhum Brasil Existe. Rio de Janeiro: Topbooks, 2000, pp. 615-626.

FRITSCH, Winston. "1922: A Crise Econômica". Estudos Históricos, Rio de Janeiro, vol. 6, $\quad$ no. $\quad 11, \quad$ [online], $1993, \quad$ pp. $\quad 3-8$. http://bibliotecadigital.fgv.br/ojs/index.php/reh/article/viewArticle/1947 .

GUIMARÃES, Lucia Maria Paschoal. "Redemoinhos da Atlântida (1915-1920)". História Revista. Goiânia, v. 16, n. 1, p. 133-149, jan./jun. 2011.

GOMES, Ângela de Castro. "Esta Gente do Rio... os intelectuais cariocas e o modernismo". In: Estudos Históricos, Rio de Janeiro, vol. 6, n. 11, [on line], 1993, pp. 62-67, pp.

$1-2$. http://bibliotecadigital.fgv.br/ojs/index.php/reh/article/viewArticle/1954

Hobsbawm, Eric J. Nações e nacionalismo desde 1780. Rio de Janeiro: Paz e Terra, 1991.

HOLANDA, Sérgio Buarque de. Raízes do Brasil. São Paulo: Companhia das Letras, 2006.

JESUS, Carlos Gustavo Nóbrega de. Revista Gil Blas e o nacionalismo de combate (19191923) Carlos. São Paulo: Cultura Acadêmica, 2012.

JOÃO, Maria Isabel. "Percursos da Memória: centenários portugueses no século XIX". In: Camões, Revista de Letras e Culturas Lusófonas, no 8, [online], Jan/Mar de 2000. https://www.instituto-camoes.pt/revista/percursmemo.htm .

JUNQUEIRA, Júlia Ribeiro. "As Comemorações do Sete de Setembro em 1922: Uma Re(leitura) da História do Brasil". Revista de História Comparada, Rio de Janeiro, 52: 155-178, 2011. 
LEAL, Ernesto Castro. "A Cruzada Nacional D. Nuno Álvares Pereira e as origens do Estado Novo (1918-1938)". In: Análise Social, no. 148, vol. XXXIII, Instituto de Ciências Sociais (ICS), Universidade de Lisboa, 1998, pp. 823-851.

. "A Ideia de Confederação Luso-Brasileira nas primeiras décadas do século XX", pp. 5-20, In: Ibérica, Ano III, Vol IV, № 12, Juiz de Fora, dezembro/2009 - março/2010. Disponível em: http://www.estudosibericos.com/index.php/edicoes/iberica-volume-4/vol-iv-no12-juiz-de-fora-dez-2009-mar-2010.html .

LEMOS, Clarici Caldini. Os Bastiões da Nacionalidade: Nação e Nacionalismo nas obras de Elysio de Carvalho. Dissertação de Mestrado em História, Universidade Federal de Santa Catarina (UFSC), Florianópolis, 2010.

LIPPI OLIVEIRA, Lúcia. A questão nacional na Primeira República. São Paulo: Brasiliense: Brasília: CNPq, 1990.

"Imaginário Histórico e Poder Cultural: as comemorações do descobrimento". Estudos Históricos, Rio de Janeiro, vol. 14, no. 26, [online], 2000, pp.

183-202.

http://bibliotecadigital.fgv.br/ojs/index.php/reh/article/viewArticle/2122 .

LOGUERCIO, Edgardo Alfredo. Pan Americanismo versus Latino Americanismo. Origens de um debate, na virada dos séculos XIX-XX. Dissertação de Mestrado, Programa de Integração da América Latina da Universidade de São Paulo, 2007.

MACHADO, Álvaro Manuel. A Geração de 70 - uma revoluçãoo cultural e literária. Lisboa: Instituto de Cultura e Língua Portuguesa, 1986.

MAGALHÃES, Romero J. (pref.), REIS, Maria Alice (seleção de textos). A pedagogia e o ideal republicano em João de Barros. Lisboa: Terra Livres, 1979.

MARQUES, Rosália Augusta da Cunha. A Viagem do Presidente António José de Almeida no Âmbito das Relações com o Brasil no Final da I República. Dissertação de Mestrado, Faculdade de Letras, Universidade do Porto, 1998.

MARTINHO, Francisco Carlos Palomanes. "O imigrante português no mundo do trabalho, nos movimentos sociais e nas organizações sociais do Rio". In: LESSA, Carlos (org.), Os Lusíadas na Aventura do Rio Moderno. Rio de Janeiro: Editora Record, 2002.

MOTTA, Marly Silva da. A nação faz cem anos: a questão nacional no centenário da independência. Rio de Janeiro: Editora FGV: CPDOC, 1992. Disponível em: http://hdl.handle.net/10438/6770.

. "1922: em busca da cabeça do Brasil moderno". Rio de

Janeiro, CPDOC, [online], 1994, 8f. http://hdl.handle.net/10438/4133 .

MÜLLER, Fernanda Suelly. (Re)vendo as páginas, (re)visando os laços e (des)atando os nós: as relações literárias e culturais luso-brasileiras através dos periódicos portugueses (1899-1922). Tese de doutorado, Programa de Pós-Graduação em Literatura Portuguesa, FFLCH/USP, São Paulo, 2011. 
NEEDEL, Jeffrey D. Belle Époque Tropical: sociedade e cultura de elite no Rio de Janeiro na virada do século. São Paulo: Companhia das Letras, 1993.

NEVES, Lúcia Maria Bastos P. "A guerra de penas: os impressos políticos e a independência do Brasil". Revista Tempo: Dossiê - Descobrimentos e Redescobrimentos do Brasil. Niterói: Universidade Federal Fluminense (UFF), vol. 4, no. 8, Dezembro/1999. Disponível em: http://www.historia.uff.br/tempo/artigos_dossie/artg8-3.pdf .

OLIVEIRA, Ricardo de. "Euclides da Cunha, Os Sertões e a invenção de um Brasil profundo". Revista Brasileira de História, [online]. 2002, vol. 22, no 44, pp. 511-537. ISSN 1806-9347. http://dx.doi.org/10.1590/S0102-01882002000200012 .

OLIVEIRA, Márcio de. "A cidade de Curitiba e os imigrantes alemães durante a Primeira Guerra Mundial, uma análise da imprensa local". Cadernos Ceru, série 2, v. 23, n. 2, dezembro de 2012.

PAES, José Paulo. "Cinco livros do Modernismo brasileiro". Estudos Avançados, São Paulo, v. 2, n. 3, [on line], 1988. http://dx.doi.org/10.1590/S010340141988000300007 .

PAIVA, Janise de Sousa. "Atlanticamente Atlântida: em busca de mares já navegados". In: Revista Convergência Lusíada - Brasil e Portugal: 500 anos de enlaces e desenlaces. Vol. 2, número especial, 2001, pp. 189-194.

PAULO, Heloisa. Aqui também é Portugal: A Colónia Portuguesa do Brasil e o Salazarismo. Coimbra: Quarteto, 2000.

PIRES, Ana Paula. António José de Almeida: o tribuno da república. Lisboa: Assembleia da República, 2011.

PEREIRA, Paulo J. dos Reis. A Política Externa da Primeira República e os Estados Unidos: a atuação de Joaquim Nabuco em Washington. São Paulo, Dissertação de Mestrado: Programa de Pós-Graduação em Relações Internacionais UNESP/UNICAMP/PUC-SP, $2005 . \quad$ Disponível em: http://www.santiagodantassp.locaweb.com.br/br/arquivos/defesas/paulo.pdf .

PINHO, Arnaldo de e NATÁRIO, Celeste (org.). A Águia e a Renascença Portuguesa no Contexto da República, 1910-2010. Porto: Universidade do Porto/Universidade Católica Portuguesa, 2011.

QUEIROZ, Helaine Nolasco. Verdeamarelo/Anta e antropofagia: narrativas de identidade nacional brasileira. Dissertação de Mestrado, Universidade Federal de Minas Gerais (UFMG), Belo Horizonte, 2010.

"Antropófago e Nhengaçu Verdeamarelo: dois manifestos em busca da identidade nacional brasileira". Anais do XXVI Simpósio Nacional de História - ANPUH, São Paulo, [on line], julho 2011. http://www.snh2011.anpuh.org/resources/anais/14/1308167440 ARQUIVO Artigo Ahpuh2011(2).pdf.

QUENTAL, P.. "A latinidade do conceito de América Latina". GEOgraphia, América do Norte, 14, jan. 2013.2 Disponível 
em:http://www.uff.br/geographia/ojs/index.php/geographia/article/view/520/338. Acesso em: 19 Jul. 2013.

QUINTAS, José Manuel. Filhos de Ramires: as origens do Integralismo Lusitano. Lisboa: Editorial Nova Ática, 2004.

RAMOS, Rui. "A Segunda Fundação". In: MATTOSO, José (dir.), História de Portugal, vol. VI, Lisboa: Editorial Estampa, 2001.

RANQUETAT JÚNIOR, Cesar Alberto. "A Campanha Cívica de Olavo Bilac e a criação da Liga da Defesa Nacional”. Publ. UEPG Humanit. Sci., Linguist., Lett. Arts, Ponta Grossa, 19 (1): 9-17, jan./jun. 2011. Disponível em http://www.revistas2.uepg.br/index.php/humanas; acesso 1/8/2013.

REIS, António. "O Grupo Seara Nova: uma resposta das elites intelectuais à crise do sistema liberal". In: Elites e Poder. A Crise do Sistema Liberal em Portugal e Espanha (1918-1931). Lisboa, Edições Colibri - CIDEHUS-UE, 2004, pp. 325-352.

REIS DE QUEIROZ, Suely R. Os radicais da república: jacobinismo ideologia e ação (1893-1897). São Paulo: Brasiliense, 1986.

RIBEIRO, Maria Aparecida. "Dois Rapsodos Tropicais: Mário de Andrade e José de Alencar". In: Hvmanitas, vol. XLVII, Coimbra, [on line], 1995. http://www.uc.pt/fluc/eclassicos/publicacoes/ficheiros/humanitas47/59 Aparecida Ribeiro.pdf .

ROCHA, Oswaldo Porto. A era das demolições: cidade do Rio de Janeiro, 1870-1920. Rio de Janeiro: Secretaria Municipal de Cultura, 1995.

ROSAS, Fernando. Portugal Século XX (1890-1976): Pensamento e Acção Política. Lisboa: Ed. Notícias, 2004.

ROSAS, Fernando e ROLLO, Maria Fernanda (coord.). "A República e a Grande Guerra”. In: História da Primeira República Portuguesa, Lisboa: Tinta da China, 2010.

RODRIGUES, João Carlos. João do Rio: uma biografia. Rio de Janeiro: Topbooks, 1996.

RODRIGUEZ, Ricardo Vélez. "A Sociologia de Sílvio Romero: método monográfico e crítica ao monocausalismo". In: Actas do /l Colóquio de Filosofia Luso-Brasileira, Ponta Delgada, Ilha de São Miguel, Açores, 1994. Disponível em: http://www.ensayistas.org/filosofos/brasil/romero/introd.htm .

SABINA RIBEIRO, Gladys. A liberdade em construção: identidade nacional e conflitos antilusitanos no Primeiro Reinado. Tese de Doutorado, Universidade Estadual de Campinas (UNICAMP), 1997.

. "Antes sem pão do que sem pátria: o antiportuguesismo nos anos da década de 1920". Brasil e Portugal: 500 anos de enlaces e desenlaces.. Convergência Lusíada, Rio de Janeiro, v. 2, pp. 147-162, 2001.

SAMUEL, Paulo. A Renascença Portuguesa: um perfil documental. Porto: Fundação Eng. António de Almeida, 1990.

SANTOS, Alfredo Ribeiro dos. A Renascença Portuguesa: um movimento cultural portuense. Porto: Fundação Eng. António de Almeida, 1990. 
SARAIVA, Arnaldo. Modernismo Brasileiro e Modernismo Português: subsídios para o seu estudo e para a história das suas relações. Campinas/SP: Editora da UNICAMP, 2004.

SEABRA PEREIRA, José Carlos. "Tempo neo-romântico (contributo para o estudo das relações entre literatura e sociedade no primeiro quartel do século XX". Análise Social, vol. XIX (77-78-79), 1983- 3으, 4으, 5ㅇ, 845-873.

"Literatura de intuitos no tempo republicano". In: BIBLOS - A República e as letras; v. VIII, 2ª série, 2010, p. 337-418 .

SERRÃO, Joel. Sistema de Ensino em Portugal. Lisboa: FCG, 1981.

SEVCENKO, Nicolau. A Revolta da Vacina: mentes insanas em corpos rebeldes. São Paulo: Scipione, 1993.

"República: da Belle Époque à Era do Rádio". In: NOVAIS, Fernando A. (coord.), História da Vida Privada no Brasil, vol. 3. São Paulo: Companhia das Letras, 2008.

SILVA, Rogério Forastieri da. Colônia e Nativismo: a História como "biografia de uma nação". São Paulo: Hucitec, 1997.

SOUZA, Raquel dos Santos M. Convergências e Divergências: revistas literárias em perspectiva. Tese de Doutorado, São Paulo, Departamento de Letras Clássicas e Vernáculas, FFLCH- Universidade de São Paulo (USP), 2008.

"Um intelectual imigrante: Álvaro Pinto e o projeto de intercâmbio Portugal-Brasil", pp. 3-4. Disponível no endereço eletrónico: http://www.reseau-amerique-latine.fr/ceisal-bruxelles/MS-MIG/MS-MIG-3MADALENO-SOUZA.pdf .

TORGAL, Luís Reis. António José de Almeida e a República. Lisboa: Círculo de Leitores, 2004.

URIBE, Jorge e SEPÚLVEDA, Pedro. "Sebastianismo e Quinto Império: o nacionalismo pessoano à luz de um novo corpus". Pessoa Plural: 1 (P./Spr. 2012): 153. Consultado em:

http://www.brown.edu/Departments/Portuguese Brazilian Studies/ejph/pessoapl ural/Issue1/PDF/I1A03.pdf, 12/11/2012.

VALENTE, Vasco Pulido. A "República Velha", 1910-1917. Lisboa: Alêtheia Editores, 2010.

VAINFAS, Ronaldo. "Colonização, miscigenação e questão racial: notas sobre equívocos e tabus da historiografia brasileira". Revista Tempo, Niterói/RJ, v. 8, pp. 7-22, Ago 1999.

VELLOSO, Mônica Pimenta. "A Brasilidade Verde-Amarela: nacionalismo e regionalismo paulista". Estudos Históricos, Rio de Janeiro, vol. 6, no. 11, [on line], 1993, pp. 89112. http://bibliotecadigital.fgv.br/ojs/index.php/reh/article/viewArticle/1952 .

VICENTE, António Pedro. "A República Portuguesa comemora a independência do Brasil: o significado da viagem de António José de Almeida ao Rio de Janeiro". In: $D a$ 
visão do Paraíso à construção do Brasil. Actas do II Curso de verão da Ericeira. Ericeira, Mar de Letras Editora, 2001, pp. 162-163.

VIEIRA, Nelson $\mathrm{H}$. Brasil e Portugal. A imagem recíproca (O mito e a Realidade na Expressão literária). Lisboa: Ministério da Educação/Instituto de Cultura e Língua Portuguesa, 1991.

VIDAL-NAQUET, Pierre. A Democracia Grega: ensaios de historiografia Antiga e Moderna. Lisboa: 1993.

WEYEMBERGH, Maurice. Charles Maurras et la Revolution Française. Paris: Librairie Philosophique J. Vrin, 1992. 